\section{To: (Receiving Organization)}

Distribution

5. Proj./Prog./Dept./Div.:

Spent Nuclear Fuel Project

8. Originator Remarks:

For approval and release.
11. Receiver Remarks:
11A. Design Baseline Document? [] Yes [x] No

3. From: (Originating Organization)
Nuclear Safety
6. Design Authority/ Design Agent/Cog. Engr.:
Barclay S. Lew

Barclay S. Lew
4. Related EDT No.:

N/A

7. Purchase Order No.:

N/A

9. Equip./Component No:

N/A

10. System/Bidg./Facility:

W-379

12. Major Assm. Dwg. No.:

N/A

13. Permit/Permit Application No.:

N/A

14. Required Response Date:

N/A

\begin{tabular}{|c|c|c|c|c|c|c|c|c|}
\hline 15. & & DAT & NSM & & (F) & (G) & $(\mathrm{H})$ & (I) \\
\hline $\begin{array}{l}\text { (A) } \\
\text { Item } \\
\text { No. }\end{array}$ & (B) Document/Drawing No. & $\begin{array}{c}\text { (C) } \\
\text { Shet } \\
\text { No. }\end{array}$ & $\begin{array}{l}\text { (D) } \\
\text { Rev. } \\
\text { No. }\end{array}$ & (E) Title or Description of Dat Transmitted & $\begin{array}{l}\text { Approval } \\
\text { Designator }\end{array}$ & $\begin{array}{c}\text { Reason } \\
\text { for Trans- } \\
\text { mittal }\end{array}$ & $\begin{array}{l}\text { Origi- } \\
\text { nator } \\
\text { Dispo- } \\
\text { sition }\end{array}$ & $\begin{array}{c}\text { Recciver } \\
\text { Disposition }\end{array}$ \\
\hline 1 & SNF-3328 & N/A & 0 & $\begin{array}{l}\text { Canister Storage Building } \\
\text { Design Basis Accident Analysis } \\
\text { Documentation }\end{array}$ & $\mathbf{S}$ & 1,2 & 1 & 1 \\
\hline & & & & & & & & \\
\hline & & & & & & & & \\
\hline & & & & & & & & \\
\hline & & & & & & & & \\
\hline & & & & & & & & \\
\hline
\end{tabular}

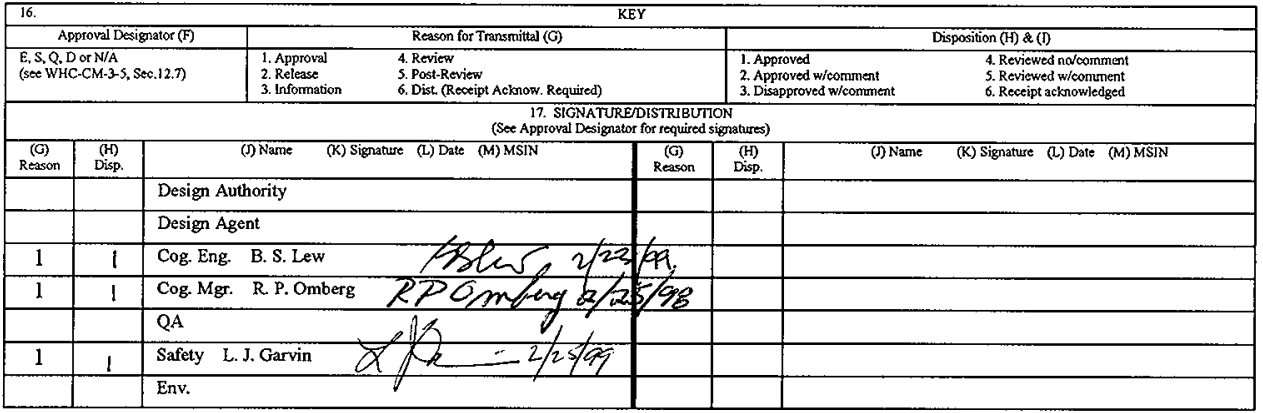

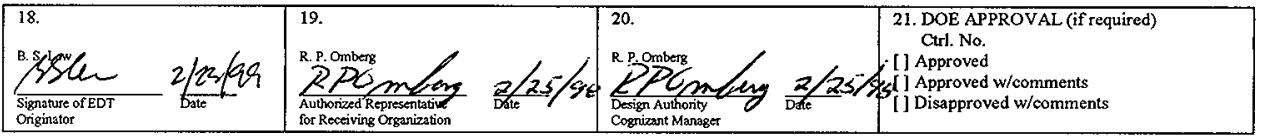

BD-7400-172-2 (05/96) GEF097 


\title{
Canister Storage Building Design Basis Accident Analysis Documentation
}

\author{
* S. D. Kopelic, * B. S. Lew, M. G. Piepho, P. D. Rittmann, \& W. T. Watson \\ Fluor Daniel Northwest, Inc., Richland, WA 99352 \\ U.S. Department of Energy Contract DE-AC06-96RL13200
}

EDT: 624295

Org Code: $2 \mathrm{~F} 200$

B\&R Code: $39 E W 40400$
UC: 620

Charge Code: $105625 / \mathrm{BB} 20$

Total Pages: 277

Key Words: Canister Storage Building, CSB, Accident Analysis, Design Basis Accident, DBA

Abstract: This document provides the detailed accident analysis to support HNF-3553, Spent Nuclear Fuel Project Final Safety Analysis Report, Annex A, "Canister Storage Building Final Safety Analysis Report." All assumptions, parameters, and models used to provide the analysis of the design basis accidents are documented to support the conclusions in the Canister Storage Building Final Safety Analysis Report.

* XWEST Group, Inc.

TRADEMARK DISCLAIMER. Reference herein to any specific commercial product, process, or service by trade name, trademark, manufacturer, or otherwise, does not necessarily constitute or imply its endorsement, recommendation, or favoring by the United States Government or any agency thereof or its contractors or subcontractors.

Printed in the United States of America. To obtain copies of this document, contact: Document Control Services, P.O. Box 950, Mailstop H6-08, Richland WA 99352, Phone (509) 372-2420; Fax (509) 376-4989.

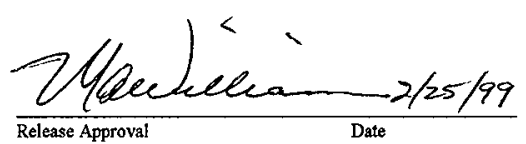

Approved for Public Release 
SNF-3328 REV 0

CANISTER STORAGE BUILDING DESIGN BASIS ACCIDENT ANALYSIS DOCUMENTATION

SNF-3328

Revision 0

S. D. Kopelic, X West

B. S. Lew, $X$ West

M .G. Piepho, Fluor Daniel Northwest, Inc.

P. D. Rittmann, Fluor Daniel Northwest, Inc.

W. T. Watson, Fluor Daniel Northwest, Inc. 
SNF-3328 REV 0

This page intentionally left blank. 


\section{CONTENTS}

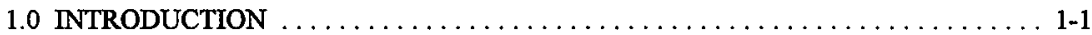

1.1 DESIGN BASIS ACCIDENT SELECTION $\ldots \ldots \ldots \ldots \ldots \ldots \ldots \ldots \ldots$ 1-1

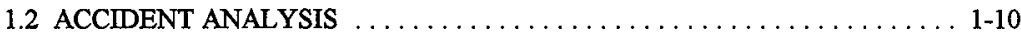

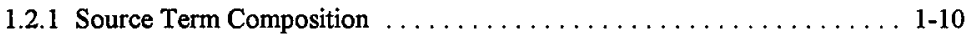

1.2 .2 Consequence Analysis $\ldots \ldots \ldots \ldots \ldots \ldots \ldots \ldots \ldots \ldots \ldots \ldots \ldots \ldots \ldots \ldots \ldots, 12$

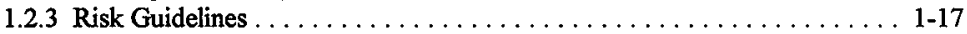

1.2.4 Limiting Design Basis Accident Assumptions . . . . . . . . . . 1-18

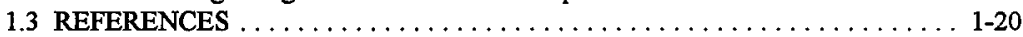

2.0 REARRANGEMENT OF MULTI-CANISTER OVERPACK INTERNALS $\ldots \ldots \ldots$ 2-1

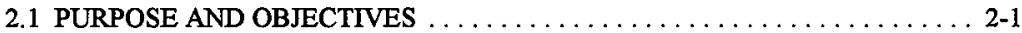

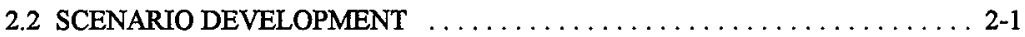

2.2.1 Cask-Multi-Canister Overpack Drop from Receiving Crane $\ldots \ldots \ldots \ldots$ 2-3

2.2.2 Cask Lid Drop onto Multi-Canister Overpack ............... 2-9

2.2.3 Drop of a Multi-Canister Overpack by the Multi-Canister Overpack Handling Machine $\ldots \ldots \ldots \ldots \ldots \ldots \ldots \ldots$ 2-9

2.2.4 Shear of a Multi-Canister Overpack by the Multi-Canister Overpack Handling Machine $\ldots \ldots \ldots \ldots \ldots \ldots \ldots \ldots \ldots \ldots .2-10$

2.2.5 Cask-Multi-Canister Overpack Shear by the Receiving Crane ....... 2-11

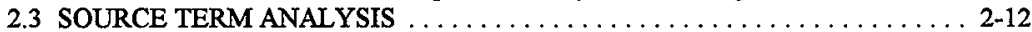

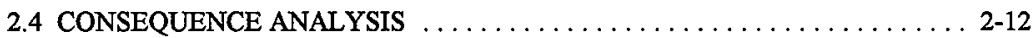

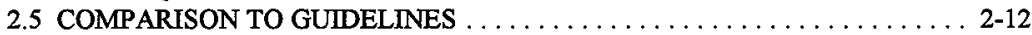

2.6 SUMMARY OF SAFETY-CLASS STRUCTURES, SYSTEMS, AND

COMPONENTS AND TECHNICAL SAFETY REQUIREMENT

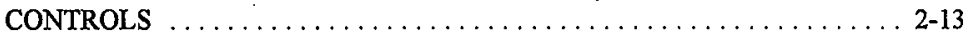

2.6.1 Possible Rearrangement of Multi-Canister Overpack

Internals Because of Shear . . . . . . . . . 2-13

2.6.2 Possible Rearrangement of Multi-Canister Overpack Internals Because of Drops . . . . . . . 2-15

2.6.3 Possible Rearrangement of Multi-Canister Internals Because of Collision . . . . . . . . . 2-29

2.6.4 Possible Rearrangement of Multi-Canister Internals

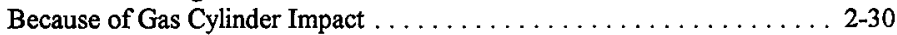

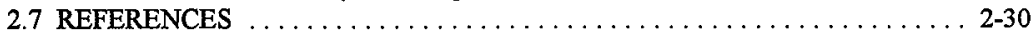

3.0 CALCULATIONS FOR GASEOUS RELEASE FROM THE MULTI-CANISTER

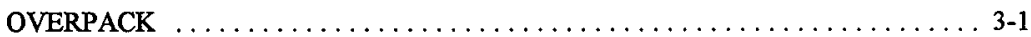

3.1 PURPOSE AND OBJECTIVES $\ldots \ldots \ldots \ldots \ldots \ldots \ldots \ldots \ldots \ldots \ldots \ldots \ldots \ldots \ldots \ldots \ldots, 1$

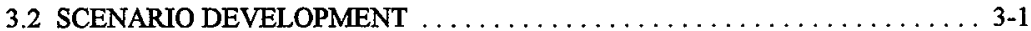

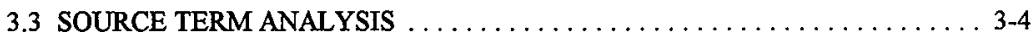

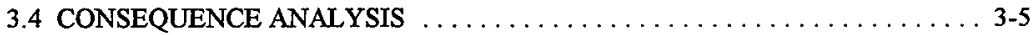

3.5 COMPARISON TO GUIDELINES $\ldots \ldots \ldots \ldots \ldots \ldots \ldots \ldots \ldots \ldots \ldots \ldots \ldots \ldots$ 


\section{CONTENTS (Continued)}

3.6 SUMMARY OF SAFETY-CLASS STRUCTURES, SYSTEMS, AND COMPONENTS AND TECHNICAL SAFETY REQUIREMENT CONTROLS . 3-8

3.6.1 Gaseous Release during the Multi-Canister Overpack

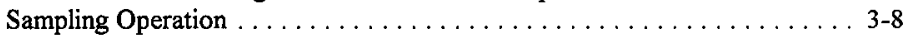

3.6.2 Gaseous Release Resulting from Overpressurization

of the Multi-Canister Overpack . . . . . . . . . . . . . . . . . . . . 3-9

3.7 REFERENCES

4.0 CALCULATIONS FOR MULTI-CANISTER OVERPACK

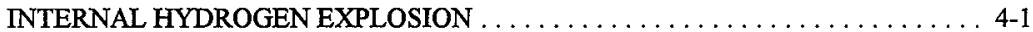

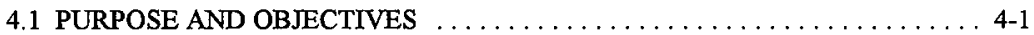

4.2 SCENARIO DEVELOPMENT $\ldots \ldots \ldots \ldots \ldots \ldots \ldots \ldots \ldots \ldots \ldots \ldots$ 4-1

4.2.1 Hydrogen Explosion During Storage due to Radiolysis $\ldots \ldots \ldots \ldots \ldots$ 4-2

4.2.2 Hydrogen Explosion Following Oxygen Addition

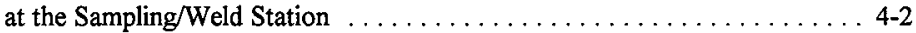

4.2.3 Hydrogen Explosion Following an Air Ingress ............... 4-3

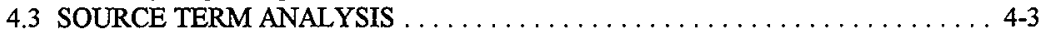

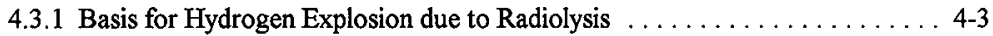

4.3.2 Basis for a Hydrogen Explosion due to Oxygen in the Helium System . . . . . 4-9

4.3.3 Basis for Hydrogen Explosion After an Air Ingress . . . . . . . . . . . 4-11

4.3.4 Method to Estimate Peak Pressures due to Hydrogen Combustion . . . . 4 4-11

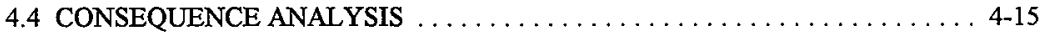

4.4.1 Downwind Dose Calculation Methodology ................ 4-15

4.4.2 Consequences of a Hydrogen Explosion Due to Radiolysis . . . . . . . . 4-16

4.4.3 Consequences of a Hydrogen Explosion Following

Oxygen Addition at the Sampling/Weld Station .............. 4-16

4.4.4 Consequences of a Hydrogen Explosion After an Air Ingress . . . . . . . . 4 4-17

4.5 COMPARISON TO GUIDELINES .................... 4-17

4.6 SUMMARY OF SAFETY-CLASS STRUCTURES, SYSTEMS, AND

COMPONENTS AND TECHNICAL SAFETY REQUIREMENT CONTROLS . 4-17

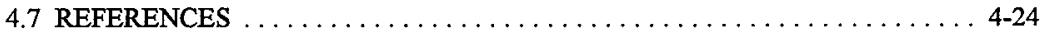

5.0 CALCULATIONS FOR MULTI-CANISTER OVERPACK

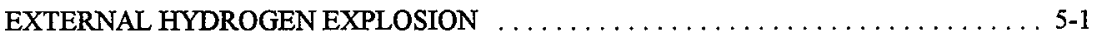

5.1 PURPOSE AND OBJECTIVES $\ldots \ldots \ldots \ldots \ldots \ldots \ldots \ldots \ldots \ldots \ldots \ldots, 5-1$

5.2 SCENARIO DEVELOPMENT $\ldots \ldots \ldots \ldots \ldots \ldots \ldots \ldots \ldots \ldots \ldots \ldots$ 5-1

5.2.1 Hydrogen Explosion During Multi-Canister Overpack Cask Venting . . . . . 5-2

5.2.2 Hydrogen Explosion from Receiving a Wet Cask-MCO ............ 5-2

5.2.3 Hydrogen Explosion During Multi-Canister Overpack Handling $\ldots \ldots \ldots$ 5-3

5.2 .4 Hydrogen Explosion During Interim Storage . . . . . . . . . . . 5-3

5.2.5 Hydrogen Explosion During Multi-Canister Overpack Gas Sampling . . . . . 5-3

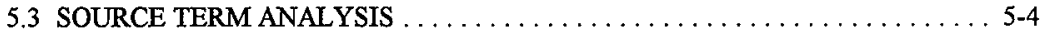




\section{CONTENTS (Continued)}

5.3.1 Hydrogen Accumulation and Other Parameters $\ldots \ldots \ldots \ldots \ldots \ldots \ldots$ 5-4

5.3.2 Basis for Hydrogen Explosion During Multi-Canister Overpack Cask Venting ..................... 5-11

5.3.3 Hydrogen Explosion During Multi-Canister Overpack Handling . . . . . . 5-18

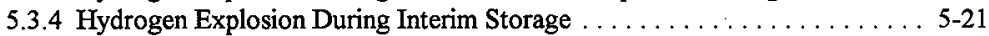

5.3.5 Hydrogen Explosion During Multi-Canister Overpack Sampling . . . . . . . 5 5-22

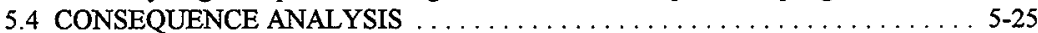

5.4.1 Downwind Dose Calculation Methodology ............... 5-26

5.4.2 Consequences of a Hydrogen Explosion After Venting the Cask . . . . . . 5-27

5.4.3 Consequences of a Hydrogen Explosion During Multi-Canister Overpack Handling $\ldots \ldots \ldots \ldots \ldots \ldots \ldots \ldots, 5-28$

5.4.4 Consequences of a Hydrogen Explosion During Interim Storage . . . . . . 5 5-28

5.4.5 Consequences of a Hydrogen Explosion During Multi-Canister Overpack Sampling $\ldots \ldots \ldots \ldots \ldots \ldots \ldots \ldots \ldots, 5,28$

5.5 COMPARISON TO GUIDELINES . . . . . . . . . . . . . . . . . 5-29

5.5.1 Mitigation of Hydrogen Explosions During Cask Venting $\ldots \ldots \ldots \ldots$ 5.30

5.5.2 Mitigation of Hydrogen Explosions Inside the

Multi-Canister Overpack Handling Machine $\ldots \ldots \ldots \ldots \ldots \ldots \ldots .5-30$

5.5.3 Mitigation of Hydrogen Explosions Inside Storage Tubes . . . . . . . . . 5-30

5.5.4 Mitigation of Hydrogen Explosions During Multi-Canister

Overpack Sampling . . . . . . . . $\ldots \ldots \ldots \ldots \ldots \ldots \ldots \ldots$ 5-31

5.6 SUMMARY OF SAFETY-CLASS STRUCTURES, SYSTEMS, AND COMPONENTS AND TECHNICAL SAFETY REQUIREMENT CONTROLS . 5-31

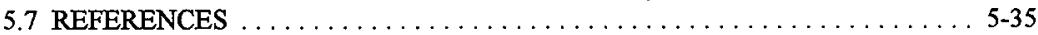

6.0 CALCULATIONS FOR THERMAL RUNAWAY REACTIONS

INSIDE THE MULTI-CANISTER OVERPACK $\ldots \ldots \ldots \ldots \ldots \ldots \ldots \ldots, 6,1$

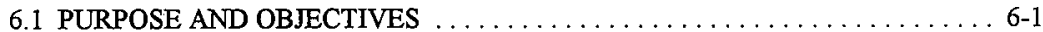

6.2 SCENARIO DEVELOPMENT $\ldots \ldots \ldots \ldots \ldots \ldots \ldots \ldots \ldots \ldots \ldots, 6-1$

6.2.1 Thermal Runaway Reaction from Water

Reacting with Uranium and Hydride $\ldots \ldots \ldots \ldots \ldots \ldots \ldots \ldots, 6,2$

6.2.2 Thermal Runaway Reaction from Oxygen Reacting

with Uranium Hydride and Uranium $\ldots \ldots \ldots \ldots \ldots \ldots \ldots \ldots, 6-10$

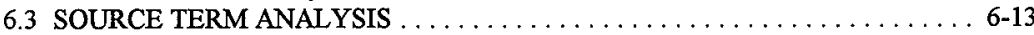

6.4 CONSEQUENCE ANALYSIS $\ldots \ldots \ldots \ldots \ldots \ldots \ldots \ldots \ldots \ldots \ldots, 6.13$

6.5 COMPARISON TO GUIDELINES $\ldots \ldots \ldots \ldots \ldots \ldots \ldots \ldots \ldots \ldots .6 \ldots \ldots$

6.6 SUMMARY OF SAFETY-CLASS STRUCTURES, SYSTEMS, AND COMPONENTS AND TECHNICAL SAFETY REQUIREMENT CONTROLS . 6-14

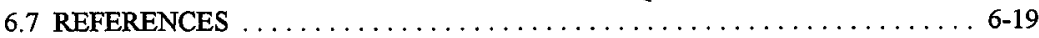

7.0 CALCULATIONS FOR VIOLATION OF DESIGN TEMPERATURE CRITERIA $\ldots$. 7 7 1

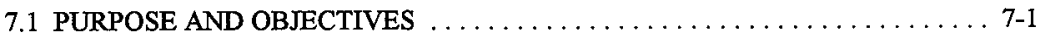




\section{CONTENTS (Continued)}

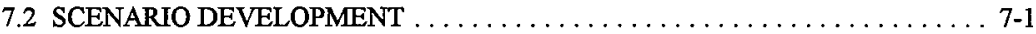

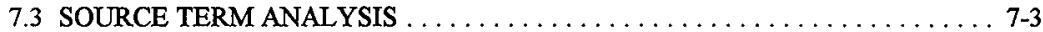

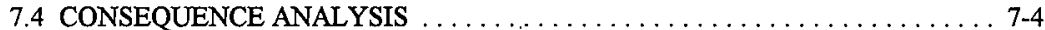

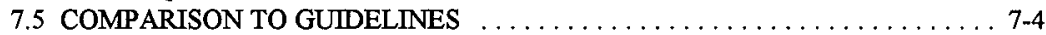

7.6 SUMMARY OF SAFETY-CLASS STRUCTURES, SYSTEMS, AND COMPONENTS AND TECHNICAL SAFETY REQUIREMENT CONTROLS . 7-4

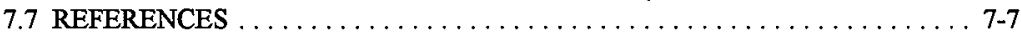

8.0 CALCULATIONS FOR RECOVERY ACTIONS RELATED TO GASEOUS RELEASES AND EXPLOSIONS FROM OVERPACK STORAGE TUBES $\ldots \ldots \ldots$ 8-1

8.1 PURPOSE AND OBJECTIVE $\ldots \ldots \ldots \ldots \ldots \ldots \ldots \ldots \ldots \ldots \ldots \ldots$ 8-1

8.2 SCENARIO DEVELOPMENT $\ldots \ldots \ldots \ldots \ldots \ldots \ldots \ldots \ldots \ldots \ldots . . \%$. 1

8.2.1 Gaseous Release Accident $\ldots \ldots \ldots \ldots \ldots \ldots \ldots \ldots \ldots \ldots \ldots \ldots$ 8-3

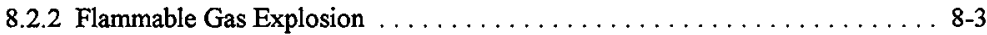

8.3 SOURCE TERM DEVELOPMENT AND CONSEQUENCE ANALYSIS . . . . 8-5

8.3.1 Gaseous Release Accident . . . . . . . . . . . . . . . . . . 8-5

8.3 .2 Flammable Gas Explosion $\ldots \ldots \ldots \ldots \ldots \ldots \ldots \ldots \ldots \ldots \ldots \ldots$ 8-10

8.4 CONSEQUENCE ANALYSIS $\ldots \ldots \ldots \ldots \ldots \ldots \ldots \ldots \ldots \ldots \ldots \ldots .11$

8.4 .1 Gaseous Release Accident $\ldots \ldots \ldots \ldots \ldots \ldots \ldots \ldots \ldots \ldots \ldots \ldots$ 8-11

8.4 .2 Flammable Gas Explosion $\ldots \ldots \ldots \ldots \ldots \ldots \ldots \ldots \ldots \ldots \ldots$ 8-13

8.5 COMPARISON TO GUIDELINES $\ldots \ldots \ldots \ldots \ldots \ldots \ldots \ldots \ldots \ldots .8 \ldots \ldots \ldots$

8.6 SUMMARY OF SAFETY-CLASS STRUCTURES, SYSTEMS, AND COMPONENTS AND TECHNICAL SAFETY REQUIREMENT CONTROLS . 8-17 8.6.1 Safety-Class Carbon Steel Base Slab Embeds ............... 8-18 8.6.2 Overpack Storage Tube, Bellows Assembly, Tube Plugs, and Tube Base Assemblies . . . . . . . . . . . . . . . . . . . . . . 8-19

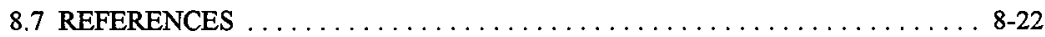

APPENDIXES

A EVENT TREE ANALYSIS FOR DESIGN BASIS ACCIDENTS $\ldots \ldots \ldots \ldots$ A-1

B ISO-PC OUTPUT TO ESTIMATE HIGH-EFFICIENCY PARTICULATE AIR FILTER LOADING $\ldots \ldots \ldots \ldots \ldots \ldots \ldots \ldots \ldots \ldots \ldots \ldots \ldots \ldots \ldots$

C KEY INPUT PARAMETERS FOR THERMAL RUNAWAY FUEL REACTIONS INSIDE A MULTI-CANISTER OVERPACK

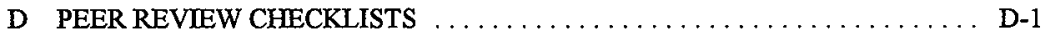




\section{SNF-3328 REV 0}

\section{LIST OF FIGURES}

3-1 Logic Diagram for Canister Storage Building Pressurized Gaseous Release . . . . . . . F3-1

3-2 Gaseous Release at the Sampling/Weld Station and Mitigating Features . . . . . . . . F3-2

4-1 General Sequence for Internal Hydrogen Explosions . . . . . . . . . . . . . . F4-1

4-2 Event Diagram of a Hydrogen Explosion due to Oxygen in the Helium System . . . . . F4-2

4-3 Fractions of Total Multi-Canister Overpack Power by Radiation Type . . . . . . . . . F4-3

4-4 Oxygen Production (no scrap baskets; intact fuel) $\ldots \ldots \ldots \ldots \ldots \ldots \ldots \ldots$. . F4-4

4-5 Hydrogen Production (no scrap baskets; intact fuel) $\ldots \ldots \ldots \ldots \ldots \ldots \ldots \ldots$ F4-5

4-6 Bounding Gas Concentration and Multi-Canister Overpack Pressure . . . . . . . . . F4-6

5-1 General Sequence for External Hydrogen Explosions $\ldots \ldots \ldots \ldots \ldots \ldots \ldots \ldots$. . . F5-1

5-2 Hydrogen Explosion in the Confinement Tent Exhaust System . . . . . . . . . . F5-2

5-3 Hydrogen Explosion in the Multi-Canister Overpack Handling Machine and Mitigating Features $\ldots \ldots \ldots \ldots \ldots \ldots \ldots \ldots \ldots \ldots \ldots \ldots \ldots \ldots \ldots$

5-4 Hydrogen Explosion in a Storage Tube and Mitigating Features . . . . . . . . F5-4

5-5 Hydrogen Explosion in the Sample Hood and Mitigating Features $\ldots \ldots \ldots$. . . . F5-5

5-6 Fuel, Multi-Canister Overpack, and Cask Temperatures Enroute to Canister Storage Building $\ldots \ldots \ldots \ldots \ldots \ldots \ldots \ldots \ldots \ldots \ldots$

5-7 Multi-Canister Overpack and Cask Pressures Enroute to Canister Storage Building . . F5-7

5-8 Hydrogen Concentrations in the Cask Enroute to Canister Storage Building . . . . . . F5-8

5-9 Multi-Canister Overpack Handling Machine Gas Concentrations with No Ventilation . . F5-9

5-10 Gas Concentrations in a Storage Tube with One Multi-Canister Overpack. . . . . . F5-10

$5-11$ Gas Concentrations in the Sample Hood $\ldots \ldots \ldots \ldots \ldots \ldots \ldots \ldots \ldots \ldots$ F5-11 


\section{LIST OF FIGURES (Continued)}

6-1 Temperature Versus Time for Multi-Canister Overpack Components for Case 1, CHOT2SCE . . . . . . . . . . . . . . . . . . . . . . . . F6-1

6-2 Temperature Versus Time for Multi-Canister Overpack Components in Bottom Fuel Basket and Pressure Versus Time for Case 1, CHOT2SCE

6-3 Temperature Versus Time for Multi-Canister Overpack Components for Case 2, CHOT2SCR

6-4 Temperature Versus Time for Multi-Canister Overpack Components in Bottom Fuel Basket and Pressure Versus Time for Case 2, CHOT2SCR . . . . . . . . . . F F-4

6-5 Temperature Versus Time for Multi-Canister Overpack for Case 3, COXY2SCE . . . . F6-5

6-6 Temperature Versus Time for Multi-Canister Overpack Components in Bottom Fuel Basket and Pressure Versus Time for Case 3, COXY2SCE . . . . . . . . . F6-6

6-7 Pressure Versus Time for Multi-Canister Overpack for Case 4, CAIR2SC F6-7 


\section{LIST OF TABLES}

1-1 Binned Listing of Candidate Accidents

1-2 Summary of Consequences for Bounding Design Basis Accidents . . . . . . . . . . 1-9

1-3 Atmospheric Transport Factors Used in Accident Analyses

for the Canister Storage Building

1-4 Composition of K Basins Fuel and the Dose per Unit of Intake

1-5 Radiological Evaluation Guidelines and Limits

1-6 Key K Basins and Cold Vacuum Drying Facility Performance Assumptions

2-1 Multi-Canister Overpack Process Steps and Possible Drop, Shear,

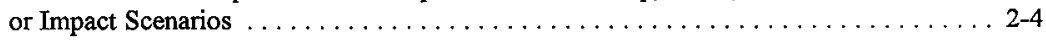

2-2 Summary of Safety Features Required to Prevent Rearrangement of Multi-Canister Overpack Internals

3-1 Maximum Individual Locations and Air Transport Factors Used in the Calculations . . . 3-6

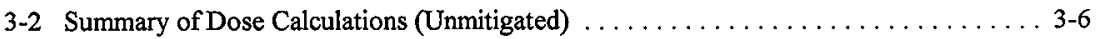

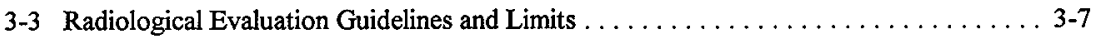

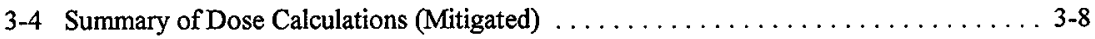

3-5 Summary of Safety Features Required to Mitigate the Consequences of a

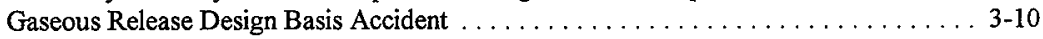

4-1 Gas Production and Removal Reactions in the Multi-Canister Overpack . . . . . . . . 4-4

4-2 Parameters to Model the Decreasing Multi-Canister Overpack Power Level . . . . . . . . 4-6

4-3 Parameters for Calculating the Rate of Hydrogen and Oxygen Generation

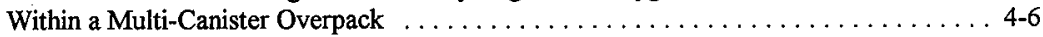

4-4 Radiolysis Removal Fractions. $\ldots \ldots \ldots \ldots \ldots \ldots \ldots \ldots \ldots \ldots \ldots \ldots \ldots \ldots \ldots$

4-5 Parameters to Determine Heat Capacities $\ldots \ldots \ldots \ldots \ldots \ldots \ldots \ldots \ldots \ldots \ldots$ 4-11 


\section{LIST OF TABLES (Continued)}

4-6 Effect of Hydrogen Inventory in the Multi-Canister Overpack

on Combustion Pressures.

4-7 Comparison of Doses with Risk Guidelines for Downwind Receptors from

a Bounding Internal Hydrogen Explosion at the Canister Storage Building

4-8 Summary of Safety Features Required to Mitigate the Consequences of a Multi-Canister Overpack Internal Hydrogen Explosion . . . . . . . . . . . . . 4 4-19

5-1 Volumes Assumed for Hydrogen Accumulation $\ldots \ldots \ldots \ldots \ldots \ldots \ldots \ldots \ldots \ldots \ldots \ldots \ldots$

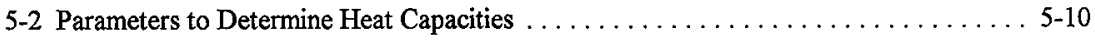

5-3 Hydrogen and Oxygen Volumes at the Time of Venting $\ldots \ldots \ldots \ldots \ldots \ldots \ldots$ 5-16

5-4 Peak Hydrogen Concentration for Various Add/Removal Factors . . . . . . . . . . 5 5-20

5-5 Peak Storage Tube Concentrations for Various Multi-Canister Overpack Leak Rates . 5-22

5-6 Comparison of Doses with Risk Guidelines for Downwind Receptors from a Bounding Hydrogen Explosion During Cask Venting $\ldots \ldots \ldots \ldots \ldots \ldots$ 5-26

5-7 Comparison of Doses with Risk Guidelines for Downwind Receptors from a Bounding Hydrogen Explosion in the Sample Hood $\ldots \ldots \ldots \ldots \ldots \ldots .5429$

5-8 Summary of Safety Features Required to Mitigate the Consequences of a Multi-Canister Overpack External Hydrogen Explosion .............. 5-33

6-1 Water Mass Required to Pressurize Multi-Canister Overpack to 11.2 and 31.6 Atmospheres Versus Reaction and Gas Temperature . . . . . . . . 6-4

6-2 Bounding Water Mass and Availability for Reactions in Multi-Canister Overpack . . . . 6-6

6-3 Additional Water Mass Needed to Pressurize Multi-Canister Overpack to 11.2 and 31.6 Atmospheres for Different Gas Temperatures . . . . . . . . . . . . . . . 6 6

6-4 Summary of Safety Features Required to Prevent a Multi-Canister Overpack Thermal Runaway

7-1 Safety Function and Classification of Structures, Systems, and Components for Violation of Design Temperature Criteria Design Basis Accidents 


\section{LIST OF TABLES (Continued)}

8-1 Dose Calculation Summary for a Multi-Canister Overpack Gaseous Release Accident inside an Overpack Storage Tube without Subsequent Flammable Gas Explosion $\ldots \ldots \ldots \ldots \ldots \ldots \ldots \ldots \ldots \ldots \ldots \ldots \ldots \ldots$

8-2 Dose Calculation Summary for Gaseous Release Accident from a Contaminated Overpack Storage Tube Following a Multi-Canister Overpack Pressurized Release . . 8-16

8-3 Dose Calculation Summary for Flammable Gas Explosion Accident with a Multi-Canister Overpack inside an Overpack Storage Tube

8-4 Safety Function and Classification of Structures, Systems, and Components Involved in Recovery Actions Related to Gaseous Releases and Explosions from Overpack Storage Tubes 
SNF-3328 REV 0

This page intentionally left blank. 


\subsection{INTRODUCTION}

The calculations in this document address the design basis accidents (DBAs) selected for analysis in the final safety analysis report for the Canister Storage Building (CSB). The objective is to determine the maximum credible quantity of radioactive particulate available at the CSB and to use that quantity to determine the amount of radioactive material that could be credibly released during the DBAs. The radioactive material released is used to determine dose consequences to receptors. The dose consequences are compared with the appropriate evaluation guidelines and release limits to ascertain the need for preventive and mitigative controls.

\subsection{DESIGN BASIS ACCIDENT SELECTION}

The hazardous conditions identified by the CSB hazard analysis (HNF-SD-SNF-HIE-001) have been used to select candidate accidents for more detailed analysis. The general selection criteria used were consistent with the U.S. Department of Energy (DOE) standard DOE-STD-3009-94, Preparation Guide for U.S. Department of Energy Nonreactor Nuclear Facility Safety Analysis Reports: "The range of accident scenarios analyzed in a SAR should be such that a complete set of bounding conditions to define the envelope of accident conditions to which the operation could be subjected are evaluated and documented."

The selection of candidate accidents was based on characterizing risk from, and developing controls for, a representative set of hazardous conditions. A hazardous condition is generally considered to be representative of other hazardous conditions if it has similar release characteristics and involves similar initiators. Hazardous conditions that represent the most severe consequences and the highest risk (a combination of frequency and consequences) within each set of representative hazards are selected as candidate accidents for further analysis. The representative hazardous conditions bound conditions with lesser but similar potential consequences; represent the highest risk; or, while not necessarily bounding, present some unique but important phenomenological challenge to system safety. The accident selection process comprises five steps.

1. Initial screening. Hazardous conditions with unmitigated offsite consequences or onsite, collocated worker consequences are considered for representative accident selection through a ranking of relative, overall (frequency and consequences) risk.

2. Assignment of release attributes. Each hazardous condition is described with certain release attributes in the case for the CSB (event initiatives and release forms) related to uncontrolled release of the material at risk. This ensures that at least one candidate accident is selected to represent each unique set of release conditions.

3. Creation of hazardous material release bins. After assigning release attributes, the hazardous conditions are collected to form release categories, or "bins." All hazardous conditions with common initiators and release forms are grouped and ranked by 
estimated consequence and frequency. Representative and bounding accidents are chosen to represent all the hazardous conditions within a particular bin.

4. Selection of representative bounding hazardous conditions for each release attribute category. Within each release attribute bin, the most severe hazardous condition is selected. These accidents are the representative and bounding accidents selected for further quantitative analysis as DBAs.

5. Selection of unique hazardous conditions. Hazardous conditions are selected to represent additional unique causes within each release attribute bin. This is done to support development of controls for accidents with similar consequences but with different causes.

The hazardous conditions are grouped by candidate accident to facilitate incorporation of the information and conclusions from the accident analysis into the hazard analysis results when considering controls and hazard classification. The list of six candidate accidents resulting from the hazards binning process for the CSB facility is presented in Table 1-1. Chapters 2.0 through 7.0 describe the analyses of these accidents.

Chapter 2.0

Possible Rearrangement of Multi-Canister Overpack Internals

Principal Analyst W. T. Watson

Peer Review J. V. Nelson

The bounding scenario for this accident category describes a physical shear force applied to the multi-canister overpack (MCO) by the MCO handling machine (MHM) such that containment of the fuel is breached and criticality geometry control is lost. The unmitigated consequences of this event are expected to violate criticality limits and may exceed the offsite release limits. Because this event may affect criticality geometry control, features are identified, consistent with DOE Order 5480.23, Nuclear Safety Analysis Reports, and HNF-PRO-704, Hazard and Accident Analysis Process, to prevent this accident. Safety-class features selected for this event include MHM seismic restraints and MHM interlocks that ensure that the seismic restraints are applied and that the MHM trolley, bridge, and turret drives cannot operate when the $\mathrm{MCO}$ is in a position where it could be subjected to a lateral force. The MHM interlocks and restraints combine to prevent the shear of the MCO. Because this event is prevented, this scenario does not occur and there is no need to bring this event to a stable state. 
Table 1-1. Binned Listing of Candidate Accidents. (2 sheets)

\begin{tabular}{|c|c|c|c|}
\hline Candidate accident & Risk ranking & $\begin{array}{l}\text { Release or change } \\
\text { energy }\end{array}$ & Reference designator \\
\hline \multicolumn{4}{|c|}{ 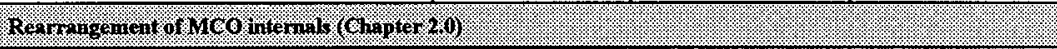 } \\
\hline $\begin{array}{l}\text { Possible rearrangement of } \mathrm{MCO} \\
\text { internals due to a drop or shear }\end{array}$ & $\begin{array}{l}9 \\
9 \\
9 \\
9 \\
9 \\
9 \\
9 \\
9 \\
9 \\
9 \\
9 \\
6\end{array}$ & $\begin{array}{c}\text { Medium } \\
\text { Medium }^{b} \\
\text { Medium }^{b} \\
\text { Low }^{b} \\
\text { Low }^{b} \\
\text { Low }^{b} \\
\text { Low }^{b} \\
\text { Medium }^{b} \\
\text { Medium } \\
\text { Medium }^{b} \\
\text { Medium } \\
\text { Medium }^{b}\end{array}$ & $\begin{array}{l}\text { OA-E-07 } \\
\text { OA-F-07 } \\
\text { OA-G-03,-13 } \\
\text { SA-E-07 } \\
\text { SA-F-07b } \\
\text { WS-E-07 } \\
\text { WS-F-07 } \\
\text { WS-G-03a, -13 } \\
\text { SA-G-03a, -03b, -13 } \\
\text { TV-G-13 } \\
\text { OU-R-01 } \\
\text { OU-P-05 }\end{array}$ \\
\hline $\begin{array}{l}\text { Possible rearrangement of MCO } \\
\text { internals due to collision }\end{array}$ & 8 & Medium & SA-F-05 \\
\hline $\begin{array}{l}\text { Possible rearrangement of MCO } \\
\text { internals due to impact from gas } \\
\text { cylinder }\end{array}$ & 5 & Medium & $\begin{array}{l}\text { TV-F-06 } \\
\text { SA-F-06 } \\
\text { WS-F-06 }\end{array}$ \\
\hline \multicolumn{4}{|l|}{ 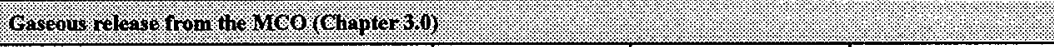 } \\
\hline Pressurized release from $\mathrm{MCO}^{*}$ & $\begin{array}{l}9 \\
6 \\
5 \\
5 \\
5 \\
5 \\
5 \\
5 \\
5\end{array}$ & $\begin{array}{l}\text { Medium } \\
\text { Low } \\
\text { High } \\
\text { Medium } \\
\text { Medium } \\
\text { Medium } \\
\text { Medium } \\
\text { Medium } \\
\text { Medium }\end{array}$ & $\begin{array}{l}\text { SA-G-03a } \\
\text { OA-D-01 } \\
\text { WS-H-06a, -07, -11 } \\
\text { WS-F-02,-05 } \\
\text { WS-F-06 } \\
\text { WS-G-01 } \\
\text { WS-G-03b } \\
\text { WS-G-04 } \\
\text { WS-G-06 }\end{array}$ \\
\hline Pressurized release from cask-MCO & 9 & Low & TV-G-13 \\
\hline \multicolumn{4}{|c|}{ 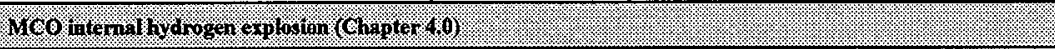 } \\
\hline Hydrogen deflagration ${ }^{2}$ & $\begin{array}{l}9 \\
9 \\
9 \\
9\end{array}$ & $\begin{array}{l}\text { High } \\
\text { High } \\
\text { High } \\
\text { High }\end{array}$ & $\begin{array}{l}\text { WS-H-06b } \\
\text { WS-J-06 } \\
\text { OA-J-06a, -06c } \\
\text { SA-J-06a }\end{array}$ \\
\hline \multicolumn{4}{|c|}{ 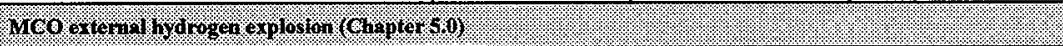 } \\
\hline External deflagration ${ }^{*}$ & $\begin{array}{l}5 \\
9\end{array}$ & $\begin{array}{l}\text { High } \\
\text { High }\end{array}$ & $\begin{array}{l}\text { WS-L-11 } \\
\text { WS-J-06b }\end{array}$ \\
\hline
\end{tabular}


Table 1-1. Binned Listing of Candidate Accidents. (2 sheets)

\begin{tabular}{|c|c|c|c|}
\hline Candidate accident & Risk ranking & $\begin{array}{l}\text { Release or change } \\
\text { energy }\end{array}$ & Reference designator \\
\hline \multicolumn{4}{|c|}{ 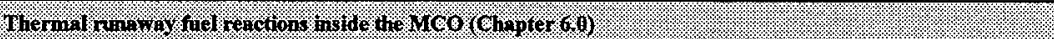 } \\
\hline Runaway reaction" & 9 & High & WS-H-06b \\
\hline Fuel reaction with air & $\begin{array}{l}9 \\
9 \\
9\end{array}$ & $\begin{array}{l}\text { High } \\
\text { High } \\
\text { High }\end{array}$ & $\begin{array}{l}\text { SA-J-10a } \\
\text { OA-J-10a } \\
\text { WS-J-10a }\end{array}$ \\
\hline Fuel reaction with water & $\begin{array}{l}9 \\
9 \\
9\end{array}$ & $\begin{array}{l}\text { High } \\
\text { High } \\
\text { High }\end{array}$ & $\begin{array}{l}\text { SA-J-10b } \\
\text { OA-J-10b } \\
\text { WS-J-10b }\end{array}$ \\
\hline Fuel exposed to air & $\begin{array}{l}9 \\
9 \\
9 \\
9 \\
9 \\
9 \\
9\end{array}$ & $\begin{array}{l}\text { Medium } \\
\text { Medium } \\
\text { Low } \\
\text { Low } \\
\text { Low } \\
\text { Low } \\
\text { Low }\end{array}$ & $\begin{array}{l}\text { WS-E-07 } \\
\text { WS-F-07 } \\
\text { SA-E-07 } \\
\text { SA-F-07b } \\
\text { OA-E-07 } \\
\text { OA-F-07 } \\
\text { SA-F-05 }\end{array}$ \\
\hline \multicolumn{4}{|c|}{ 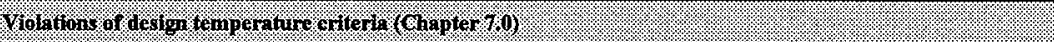 } \\
\hline $\begin{array}{l}\text { Violation of design temperature } \\
\text { criteria }^{a}\end{array}$ & $\begin{array}{l}7 \\
6\end{array}$ & $\begin{array}{l}\text { Low } \\
\text { Medium }\end{array}$ & $\begin{array}{l}\text { WS-B-07 } \\
\text { VL-B-07 }\end{array}$ \\
\hline
\end{tabular}

- Chosen as a representative and bounding accident for further accident analysis development.

'Energy was considered that could rearrange the internals of the MCO - falling onto the deck was viewed as higher energy than falling into the service or sample pit with impact absorbers present; falling into the tube with impact absorbers present was viewed as higher energy than falling into the service or the sample pit with an impact absorber present.

$$
\mathrm{MCO}=\text { multi-canister overpack }
$$


Principal Analyst

S. D. Kopelic

Peer Review

P. D. Rittmann

Two bounding scenarios have been identified for this accident category. One accident scenario describes the overpressurization of the MCO by the inert gas system when a monitored MCO is injected with inert gas after sampling. Exceeding the design pressure of the MCO could lead to criticality geometry control violations and requires safety-class controls to prevent this accident. The safety-class feature selected to prevent this event is redundant pressure safety valves on the inert gas system lines to protect the MCO from overpressure conditions. The unmitigated scenario is brought to a stable state by allowing the inert gas system and the MCO to depressurize to atmospheric pressure. Any contamination is cleaned consistent with radiation control procedures. The off-normal MCO is handled within recovery operations under emergency response procedures, with the preferred approach being to move the off-normal MCO to the overpack storage tube for long-term observation and storage.

A second bounding scenario is a pressurized leak of gas and entrained particulate from the $\mathrm{MCO}$ at the sampling/weld station. The unmitigated consequences of this event do not exceed the offsite release limits but do exceed the onsite evaluation guidelines. No safety-class features are required to prevent or mitigate this event. Safety-significant features identified to mitigate this event include the sample hood and exhaust system, an exhaust flow indicating device, pressure tests to verify the sample connection to the $\mathrm{MCO}$ before opening the $\mathrm{MCO}$ port valve, and the MHM collision avoidance system and associated interlocks, sensors, and switches. Mitigated consequences of this event are well below both offsite release limits and onsite evaluation guidelines. The unmitigated scenario is brought to a stable state by allowing the MCO to depressurize to atmospheric pressure. Any contamination is cleaned consistent with radiation control procedures. The off-normal MCO is handled within recovery operations under emergency response procedures, with the preferred approach being to move the off-normal MCO to the overpack storage tube for long-term observation and storage. 
Principal Analyst $\quad$ P. D. Rittmann

Peer Review B. S. Lew

The bounding scenario for this accident category describes the ignition and explosion of a hydrogen-oxygen mixture inside an MCO when gas that is contaminated with oxygen is used to inert the MCO after sampling. The unmitigated consequences of this event do not exceed the offsite release limits, but the onsite evaluation guidelines are exceeded. No safety-class features are required to prevent or mitigate this event. The safetysignificant controls identified to prevent this event include the testing and verification of the helium purity of each gas cylinder in the inert gas system. Because the designated safety features prevent the occurrence of this event, both offsite release limits and onsite evaluation guidelines are satisfied. The unmitigated scenario is brought to a stable state by allowing the MCO to depressurize to atmospheric pressure. If the $\mathrm{MCO}$ is inside the cask, the MHM, or the storage tube, these also are allowed to depressurize to atmospheric pressure. Any contamination is cleaned consistent with radiation control procedures. The off-normal MCO is handled within recovery operations under emergency response procedures, with the preferred approach being to move the off-normal MCO to the overpack storage tube for long-term observation and storage.

Chapter 5.0
Explosion

Principal Analyst $\quad$ P. D. Rittmann
The bounding scenario for this accident category describes the accumulation of hydrogen inside an $\mathrm{MCO}$, followed by ignition and explosion of the hydrogen gas when it leaks into the sample hood and exhaust system and mixes with air. The unmitigated consequences of this event do not exceed the offsite release limits but do exceed the onsite evaluation guidelines. No safety-class features are required to prevent or mitigate this event. Safety-significant features selected to prevent this event include the sampling line and connection, the sample hood and exhaust system, verification of a minimum flow rate through the exhaust system, verification of the sample line connection, and pressure testing of the sample line before opening the MCO port valve. Because the selected safety features prevent the occurrence of this event, both offsite release limits and onsite evaluation guidelines are satisfied. The unmitigated scenario is brought to a stable state by allowing the MCO to vent any gas 
being generated. If the MCO is inside the cask, MHM, or the storage tube, these also are vented. A containment service tent is used to cover the $\mathrm{MCO}$ and vehicle, if appropriate, until the continuing gas generation has subsided to low levels a few hours after the event. Any contamination is cleaned consistent with radiation control procedures. The off-normal MCO is handled within recovery operations under emergency response procedures, with the preferred approach being to move the off-normal MCO to the overpack storage tube for long-term observation and storage.

Chapter 6.0

Calculations for Thermal Runaway Reactions Inside the Multi-Canister Overpack

Principal Analysts $\quad$ M. G. Piepho, P. D. Rittmann

Peer Review W. T. Watson

The two bounding scenarios for this accident category describe an accident that is initiated by accidentally filling the MCO with oxygen at the sampling station and an accident where the MCO is completely sheared (with total cross-sectional access to air) and extreme MCO temperatures (MCO wall temperatures greater than $100^{\circ} \mathrm{C}$ ). In the first case, the unmitigated consequences of this event will not violate the safety limit on MCO pressure nor violate criticality controls. No safety-class features are required to prevent or mitigate this event. Because no release will occur from this event, both offsite release limits and onsite evaluation guidelines are satisfied. In the second scenario, the unmitigated consequences violate criticality geometry controls and are prevented by safety-class features. The unmitigated scenario is brought to a stable state by ongoing inerting and cooling of the $\mathrm{MCO}$ at the sampling/weld station. Any contamination is cleaned consistent with radiation control procedures. The off-normal $\mathrm{MCO}$ is handled within recovery operations under emergency response procedures, with the preferred approach being to move the off-normal MCO to the overpack storage tube for long-term observation and storage.

Principal Analyst

Peer Review

The bounding scenario for this accident category describes conditions in which the MCO or CSB safety classified concrete structures could exceed their design temperatures due to the loss of air cooling. The unmitigated consequences of this event are postulated to cause unacceptable damage to safety-class equipment or structures. Safety-class features selected for this event include the CSB vault, inlet and exhaust structures, and controls for maintaining an acceptable MCO temperature at the sampling/weld station. 
The unmitigated scenario is brought to a stable state by restoring cooling and bringing the MCOs to a stable thermal condition. If the overheated $\mathrm{MCO}$ is in the sampling/weld station, glycol or forced-air cooling to the MCO is initiated. If the overheated MCOs are in the vault of the CSB, any debris is removed to restore air flow to the air intake and exhaust structures. Once a stable thermal condition is attained, the MCO is handled in accordance with recovery procedures or the vault is returned to operational status.

Chapter 8.0

Recovery Actions Related to Gaseous Releases and Explosions from Overpack Storage Tubes
Principal Analyst
W. T. Watson
Peer Review
P. D. Rittmann

This category of accidents is associated with recovery actions associated with the overpack storage tube assemblies and the tube vent and purge cart. These hazard and accident analyses for recovery actions were performed to identify functions and classify structures, systems, and components to achieve an appropriate level of defense in depth (to prevent or mitigate the radiological consequences of postulated hazards and accident events to the collocated onsite worker) and worker safety (to reduce exposure to radiation) for the overpack storage tube assemblies (OSTAs) and tube vent and purge cart. The bounding scenario for these accidents is a pressurized release of gases from an MCO into an overpack storage tube caused by either internal MCO pressure or a flammable gas explosion within the MCO. The unmitigated consequences of this event do not exceed the offsite release limits but do exceed the onsite evaluation guidelines. No safety-class features are required to prevent or mitigate this event. Safety-significant features selected to prevent this event include the OSTAs, a program to monitor the overpack storage tubes for pressure and to maintain inert gas within the tube, and a lockdown device for the overpack storage tube plug. The unmitigated scenario is brought to a stable state by venting and purging the OSTA. The tube vent and purge cart is used until the MCO is in the OSTA and the OSTA has a stable inert atmosphere. Any contamination from the unmitigated event is cleaned consistent with radiation control procedures. The off-normal MCO is handled within recovery operations under emergency response procedures, with the preferred approach being to move the off-normal MCO to another available OSTA for long-term observation and storage. Similarly, the confinement boundary functions of the tube vent and purge cart are identified as safety-significant functions.

The consequences associated with each of the six bounding DBAs are summarized in Table 1-2. Appendix A contains event tree analysis details for DBAs. 
SNF-3328 REV 0

Table 1-2. Summary of Consequences for Bounding Design Basis Accidents.

\begin{tabular}{|l|c|c|c|c|c|c|c|}
\hline \multirow{2}{*}{ Accident category } & Chapter & \multicolumn{3}{|c|}{ Offsite consequences } & \multicolumn{3}{c|}{ Onsite consequences } \\
\cline { 3 - 8 } & Release & Unmitigated & $\begin{array}{c}\text { Mitigated } \\
\text { (rem) }\end{array}$ & $\begin{array}{c}\text { EG } \\
\text { (rem) }\end{array}$ & $\begin{array}{c}\text { Unmitigate } \\
\text { d } \\
\text { (rem) }\end{array}$ & $\begin{array}{c}\text { Mitigated } \\
\text { (rem) }\end{array}$ \\
\hline $\begin{array}{l}\text { Rearrangement of } \\
\text { MCO internals }\end{array}$ & 2.0 & NA-Crit & CRIT & NA-Crit & NA-Crit & CRIT & NA-Crit \\
\hline $\begin{array}{l}\text { Gaseous release from } \\
\text { MCO }\end{array}$ & 3.0 & NA & 0.11 & NA & 1.0 & 300 & 0.3 \\
\hline $\begin{array}{l}\text { MCO internal } \\
\text { hydrogen explosion }\end{array}$ & 4.0 & 0.5 & 0.11 & 0.00 & 1.0 & 300 & 0.00 \\
\hline $\begin{array}{l}\text { MCO external } \\
\text { hydrogen explosion }\end{array}$ & 5.0 & 0.5 & 0.11 & 0.00 & 1.0 & 300 & 0.00 \\
\hline $\begin{array}{l}\text { MCO thermal } \\
\text { runaway reaction }\end{array}$ & 6.0 & 0.5 & Incredible & Incredible & 1.0 & Incredible & Incredible \\
\hline $\begin{array}{l}\text { Violation of design } \\
\text { temperature criteria }\end{array}$ & 7.0 & $\begin{array}{l}\text { NA-Crit or } \\
\text { NA-Therm }\end{array}$ & $\begin{array}{c}\text { CRIT or } \\
\text { THERM }\end{array}$ & $\begin{array}{l}\text { NA-Crit or } \\
\text { NA-Therm }\end{array}$ & $\begin{array}{l}\text { NA-Crit or } \\
\text { NA-Therm }\end{array}$ & $\begin{array}{c}\text { CRIT or } \\
\text { THERM }\end{array}$ & $\begin{array}{l}\text { NA-Crit or } \\
\text { NA-Therm }\end{array}$ \\
\hline
\end{tabular}

Note: Offsite release limits and onsite evaluation guidelines cited are for the "anticipated" event frequency category as provided in Sellers, E.D., 1997, Risk Evaluation Guidelines (REGs) to Ensure Inherently Safer Designs (Letter 97-SFD-172 to K. J. Hatch, Fluor Daniel Hanford, Incorporated, August 26), U.S. Department of Energy, Richland Operations Office, Richland, Washington.

$\mathrm{CRIT}=\quad$ consequences result in potential violation of criticality control and therefore require safety-class prevention or mitigation.

$\mathrm{EG}=$ evaluation guideline.

$\mathrm{MCO}=$ multi-canister overpack.

$\mathrm{NA}=$ mitigated offsite consequences are not applicable to safety-significant events.

NA-Crit $=$ Not applicable because consequences result in potential violation of criticality control, independent of radiological consequences. Therefore, safety-class prevention features are applied to preclude violation of criticality control and no dose consequences occur for this event.

NA-Therm $=$ Not applicable because consequences result in damage to safety structures that potentially violate criticality geometry controls, independent of radiological consequences. Therefore, safety-class prevention features are applied to preclude thermal damage/violation of criticality control and no dose consequences occur for this event.

THERM $=$ consequences result in thermal damage to safety-class operating deck and possible damage to the MCO. 


\subsection{ACCIDENT ANALYSIS}

This section presents the methodology used to develop the potential accidents that are described in Chapters 2.0 through 8.0. The accident analysis for each DBA starts with a description of the accident scenario with the major assumptions identified. The accident source term is then determined. Source terms for the accidents have been obtained through phenomenological and system response calculations. Once a source term has been determined, onsite and offsite consequences are calculated for the atmospheric transport pathway. These consequences are then compared to evaluation guidelines for onsite consequences or release limits for offsite consequences for the identification of safety-class structures, systems, and components and technical safety requirements.

\subsubsection{Source Term Composition}

The bounding source term used for the accident analyses is based on data for the fuel in the $\mathrm{K}$ East and K West Basins given in HNF-SD-SNF-TI-009, 105-K Basin Material Design Basis Feed Description for Spent Nuclear Fuel Project Facilities. HNF-SD-SNF-TI-009 defines an inventory for safety analysis by considering inventories of Mark IV, Mark IA, and single-pass reactor fuel in the K Basins. High-burnup Mark IV fuel, the fuel type that results in the highest estimated dose to people exposed to the material, was selected as the bounding inventory from the radiological dose perspective. Nuclear accountability records give the basis for the quantity, exposure variation, and decay time variation of the stored fuel. The radionuclide inventory was estimated from these data.

The MCO contains finely divided particulate material associated with oxidation of the fuel. This material includes an oxide layer on the fuel and particulate remaining on fuel surfaces and in crevices after fuel washing and racking into the $\mathrm{MCO}$ as well as expected increases in oxidation products that occur during queuing at the $\mathrm{K}$ Basins and processing at the Cold Vacuum Drying Facility (CVDF). The particulate inventory of the MCO dominates the airborne release. The radionuclide inventory of the sludge also is based on the high-burnup Mark IV fuel, which will be verified when characterization results are available and will be documented in the final safety analysis report.

The spent nuclear fuel (SNF) is primarily uranium metal, which is known to have toxicological effects. Plutonium and other transuranic heavy metals are also present in small quantities but add little to the overall toxicity of the fuel. For example, if the toxic air concentration limits for uranium are applied to neptunium, plutonium, americium, and curium, the "sum-of-fractions" indicator of toxicity (HNF-SD-SNF-TI-059) increases about $0.2 \%$. Thus, the uranium content of SNF controls the potential health impacts downwind following a postulated accident. Uranium acts like many heavy metals to damage one or more internal organs of individuals exposed to high air concentrations. The toxicity depends on the solubility of the uranium, with more soluble compounds being a greater hazard because they are transferred from the respiratory tract into the blood more quickly. 
Because any environmental release of SNF could have toxicological and radiological effects, both should be computed for comparison with consequence guidelines. A detailed comparison (FINF-SD-SNF-TI-059, Section 5.3) of the toxicological and radiological effects of airborne emissions leads to the conclusion that toxicological effects are.normally less severe than the radiological effects. The only exceptions are accidents in which new chemical forms are introduced into the CSB and then released into the air. However, scenarios with new chemicals are not deemed credible (i.e., the accident frequency is less than $1 \times 10^{-6}$ per year). The basic assumptions used to show that radiological effects are worse than toxicological effects are listed.

- The safety basis composition of SNF (HNF-SD-SNF-TI-015) was used in the comparison. The chemical forms were chosen to be the most limiting (i.e., smallest air concentration limits).

- The risk acceptance guidelines for chemical hazards are concentration limits for onsite and offsite receptors for three accident frequency categories. The risk acceptance guidelines for radiological hazards are 50-year committed effective dose equivalents for onsite and offsite receptors for the same three accident frequency categories. All combinations of receptor location and accident frequency were evaluated to determine whether chemical or radiological hazards dominated.

- Exposure duration is an important consideration for chemical hazards. For example, the permissible exposure limit-time-weighted average uses an eight-hour exposure time while the emergency response planning guidelines are based on a one-hour exposure time. In general, the longer the exposure time, the lower the air concentration limit. The comparison analysis, using concentration limits with shorter exposure times, namely 1 minute for corrosives and 15 minutes for noncorrosives, was conservative. These shorter exposure times are based roughly on the physiological response times for the two broad categories of toxic chemicals. However, exposure times from postulated accidents may exceed the times inherent in the concentration limits. In these cases, the concentration limit is reduced proportionately.

- Because SNF contains no corrosive chemicals, only the 15-minute exposure time for noncorrosive chemicals was used in the comparison. This minimum averaging time for the air concentrations downwind leads to the conclusion that puff air transport factors are not appropriate for determining the air concentrations. Puff air transport factors can only be used for release durations of less than eight minutes.

- The effects of radiological emissions are in all cases modeled using plume air transport factors regardless of the release duration. Because both the toxicological and radiological emissions for a given release duration will use the same air transport factors, the actual air transport factor has no effect on the comparison ratios that were calculated to quantify the relative hazard.

For both the onsite and offsite receptors at all accident frequency categories, the radiological effects are greater than the toxicological effects of an airborne emission. Therefore, 
the toxicological consequences of the postulated airborne releases will not require mitigating features beyond those required by the radiological consequences.

No routine chemical processes will be conducted in the CSB. Purging and backfilling the MCOs will involve the use of an inert gas (helium). Some chemicals, such as those used for equipment decontamination, may be used occasionally (HNF-SD-SNF-CM-001). However, there are no chemical inventories of concern for safety analysis considerations.

\subsubsection{Consequence Analysis}

Radiological inhalation dose consequences for each analyzed accident are based on the following factors:

- Mass of material available for release

- Airborne release fraction (or airborne release rate and release time) and respirable fraction

- Leak path factor

- Atmospheric transport and dispersion of airborne particles

- Duration of exposure

- Breathing rates

- Dose conversion factors.

The radiological dose to a maximum receptor of interest is typically determined by using the following equation:

$$
\mathrm{D}=\mathrm{M} \times \frac{\chi}{\mathrm{Q}^{\prime}} \times \mathrm{BR} \times \mathrm{UD}
$$

where

$\mathrm{D}=$ effective dose equivalent (rem)

$M \quad=$ mass of respirable airborne material released $(\mathrm{g})$

$\chi / \mathrm{Q}^{\prime}=$ time-integrated atmospheric transport factor $\left(\mathrm{s} / \mathrm{m}^{3}\right)$

$\mathrm{BR}=$ breathing rate $\left(\mathrm{m}^{3} / \mathrm{s}\right)$

UD = dose per unit respirable radioactive material inhaled $(\mathrm{rem} / \mathrm{g})$. 
The quantity of respirable material released $(M)$ is determined by the specific accident scenario. The quantity is a function of the total airborne release fraction (or airborne release rate times release time), the respirable fraction, and the leak path factor of any passive structural enclosure that may cause deposition of an airborne release before the release enters the atmosphere. The leak path factor is based on a time-integrated calculation of aerosol deposition within and release from an enclosure of given dimensions with specified leakage area, pressure, and temperature differentials. The specific value of each parameter is determined in the individual DBA analysis and based on the physical phenomena of the accident.

The atmospheric transport factor ( $\left.\chi / Q^{\prime}\right)$ is based on specific release conditions (e.g., ground level or elevated, long or short duration) and the receptor's distance from the release. The atmospheric transport factor is the time-integrated normalized air concentration at the receptor's location. The transport factor includes the dilution of an airborne contaminant caused by atmospheric mixing and turbulence. The air transport values used in this report have been generated using the GXQ computer program (WHC-SD-GN-SWD-30002 and WHC-SD-GN-SWD-30003). Table 1-3 contains the air transport values used to determine onsite and offsite consequences.

Table 1-3. Atmospheric Transport Factors Used in Accident Analyses for the Canister Storage Building.

\begin{tabular}{|c|c|}
\hline \multirow{2}{*}{ Receptor location description } & Air transport factors for various release durations ${ }^{a}$ \\
\hline & Acute (less than 1 hour) $)^{b}$ \\
\hline $\begin{array}{l}\text { Onsite } \\
(100 \mathrm{~m} \mathrm{E} \text { or } \mathrm{ESE})^{c}\end{array}$ & $3.41 \mathrm{E}-02^{\mathrm{c}}$ \\
\hline $\begin{array}{l}\text { Highway } 240 \\
(10,510 \mathrm{~m} \mathrm{~W} \text { or } 14,500 \mathrm{~m} \mathrm{ESE})^{d}\end{array}$ & $2.01 \mathrm{E}-05$ \\
\hline $\begin{array}{l}\text { Hanford Site boundary } \\
(17,390 \mathrm{~m} \mathrm{E})\end{array}$ & $1.30 \mathrm{E}-05$ \\
\hline
\end{tabular}

'Units for these values are seconds per cubic meter. In all cases the releases are assumed to be point sources at ground level to maximize the dose consequences.

No adjustment for plume meander.

Because of variation in 200 Area wind data, the largest onsite exposures depend on the release duration. For release durations between 1 and 2 hours, the worst location is $100 \mathrm{~m}$ east. Other release durations lead to the worst location at $100 \mathrm{~m}$ east-southeast.

Because of variation in 200 Area wind data, the largest exposures depend on the release duration. For release durations of one year, the worst location is $14,500 \mathrm{~m}$ east-southeast (the "Wye" barricade). Other release durations lead to the worst location at $10,510 \mathrm{~m}$ west (Washington State Highway 240). 
Air transport factors are calculated using methods found in NRC Regulatory Guide 1.145, Atmospheric Dispersion Models for Potential Accident Consequence Assessments at Nuclear Power Plants. In each wind direction, the observed frequencies of particular wind speed and stability class combinations are used to compute a value that is exceeded only $0.5 \%$ of the time. This is repeated for all 16 compass directions to determine the worst-case location.

Exposures to the collocated worker onsite are bounded by the individual at the $100 \mathrm{~m}$ location. The risk evaluation guidelines apply to this individual. Exposures to members of the public are bounded by the individuals located on Washington State Highway 240 and at the Hanford Site boundary. For assessment purposes, the U.S. Department of Energy has directed (Sellers 1996) that the Hanford Site boundary be considered the location of the offsite receptor. Consequences at the Highway 240 location are included for reference only. None of the accidents analyzed in this document adjust the air transport factors for the finite size of the source (i.e., building wake effects) or for the elevation of the release above ground level (i.e., stack effects).

The breathing rate depends on individual activity factors and exposure duration. All accidents analyzed assume the offsite and onsite receptors are exposed for no more than one hour. The breathing rate used is the light activity rate of $3.33 \times 10^{-4} \mathrm{~m}^{3} / \mathrm{s}$ given in HNF-SD-SNF-TI-059, A Discussion on the Methodology for Calculating Radiological and Toxicological Consequences for the Spent Nuclear Fuel Project at the Hanford Site.

The dose per unit intake is the 50-year dose commitment for all relevant exposure pathways per gram of radioactive material inhaled. The major radiation exposure pathway for the identified accidents is inhalation of radioactive material. Dose contributions from the submersion pathway were calculated and found to be negligible with respect to the total dose for the radionuclides of interest (Hey 1995). Doses from groundshine also are expected to be negligible because most of the radionuclides of interest are alpha emitters. Therefore, the doses from groundshine and submersion are not included in the radiological dose calculations.

Potential doses from the ingestion pathway are not considered because U.S. Department of Energy, state, and federal emergency preparedness plans limit ingestion of contaminated food in the event of an accident. DOE/RL-94-02, Hanford Emergency Response Plan, governs emergency response for all Hanford Site facilities. The primary determinant of exposure from the ingestion pathway is the effectiveness of public health measures (i.e., interdiction) rather than the severity of the accident itself. Ingestion, if it occurs, involves a relatively slow-to-develop pathway and is not considered an immediate threat to an exposed population in the same sense as the inhalation pathway. In addition, calculations in HNF-SD-SNF-TI-059 show that the contribution of ingestion to the total dose is negligible compared to the inhalation contribution.

Table 1-4 shows the composition of the K Basins fuel used to determine the committed effective dose equivalent per gram of respirable release. Nuclides with minor contributions (less than $0.1 \mathrm{mrem} / \mathrm{g}$ ) are not shown. Isotopes of plutonium, americium, and curium constitute $99.5 \%$ of the total inhalation dose. The specific dose for the safety analysis inventory is 
Table 1-4. Composition of K Basins Fuel and the Dose per Unit of Intake. (2 sheets)

\begin{tabular}{|c|c|c|}
\hline Radionuclide & $\begin{array}{l}\text { Activity } \\
\text { (Ci/MTU) }\end{array}$ & $\begin{array}{l}\text { CEDE per unit intake } \\
\text { rem } / g\end{array}$ \\
\hline${ }^{3} \mathrm{H}$ & $2.61 \mathrm{E}+01$ & $2.5 \mathrm{E}-03$ \\
\hline${ }^{14} \mathrm{C}$ & $5.53 \mathrm{E}-01$ & $1.2 \mathrm{E}-03$ \\
\hline${ }^{60} \mathrm{Co}$ & $2.09 E+00$ & $4.6 \mathrm{E}-01$ \\
\hline${ }^{85} \mathrm{Kr}$ & $3.70 E+02$ & $4.9 \mathrm{E}-04$ \\
\hline${ }^{90} \mathrm{Sr}^{\mathrm{c}}$ & $6.93 E+03$ & $1.7 \mathrm{E}+03$ \\
\hline${ }^{99} \mathrm{Tc}$ & $2.19 \mathrm{E}+00$ & $1.8 \mathrm{E}-02$ \\
\hline${ }^{113 \mathrm{~m}} \mathrm{Cd}$ & $2.78 \mathrm{E}+00$ & $4.3 \mathrm{E}+00$ \\
\hline${ }^{134} \mathrm{Cs}$ & $6.47 \mathrm{E}+00$ & $3.0 \mathrm{E}-01$ \\
\hline${ }^{137} \mathrm{Cs}^{c}$ & $9.66 \mathrm{E}+03$ & $3.1 \mathrm{E}+02$ \\
\hline${ }^{147} \mathrm{Pm}$ & $1.09 \mathrm{E}+02$ & $4.3 \mathrm{E}+00$ \\
\hline${ }^{151} \mathrm{Sm}$ & $1.02 \mathrm{E}+02$ & $3.1 \mathrm{E}+00$ \\
\hline${ }^{152} \mathrm{Eu}$ & 8.45 E-01 & $1.9 \mathrm{E}-03$ \\
\hline${ }^{154} \mathrm{Eu}$ & $1.13 \mathrm{E}+02$ & $3.2 \mathrm{E}+01$ \\
\hline${ }^{155} \mathrm{Eu}$ & $1.06 \mathrm{E}+01$ & 4.4 E-01 \\
\hline${ }^{234} \mathrm{U}$ & 3.84 E-01 & $5.1 \mathrm{E}+01$ \\
\hline${ }^{235} \mathrm{U}^{\mathrm{c}}$ & $1.27 \mathrm{E}-02$ & $1.6 \mathrm{E}+00$ \\
\hline${ }^{236} \mathrm{U}$ & $7.16 \mathrm{E}-02$ & $9.0 \mathrm{E}+00$ \\
\hline${ }^{238} \mathrm{U}^{\mathfrak{c}}$ & 3.31 E-01 & $3.9 \mathrm{E}+01$ \\
\hline${ }^{237} \mathrm{~Np}{ }^{\mathrm{c}}$ & $4.66 \mathrm{E}-02$ & $2.5 \mathrm{E}+01$ \\
\hline${ }^{238} \mathrm{Pu}$ & $1.33 \mathrm{E}+02$ & $5.2 \mathrm{E}+04$ \\
\hline${ }^{239} \mathrm{Pu}$ & $1.73 E+02$ & $7.4 \mathrm{E}+04$ \\
\hline${ }^{240} \mathrm{Pu}$ & $1.37 \mathrm{E}+02$ & $5.9 \mathrm{E}+04$ \\
\hline${ }^{241} \mathrm{Pu}^{\mathrm{e}}$ & $6.82 \mathrm{E}+03$ & $5.6 \mathrm{E}+04$ \\
\hline${ }^{242} \mathrm{Pu}$ & 8.71 E-02 & $3.6 \mathrm{E}+01$ \\
\hline${ }^{241} \mathrm{Am}$ & $4.34 \mathrm{E}+02$ & $1.9 \mathrm{E}+05$ \\
\hline${ }^{242 m} \mathrm{Am}^{\mathrm{c}}$ & 3.72 E-01 & $1.6 \mathrm{E}+02$ \\
\hline${ }^{243} \mathrm{Am}^{\circ}$ & $2.78 \mathrm{E}-01$ & $1.2 \mathrm{E}+02$ \\
\hline
\end{tabular}




\section{SNF-3328 REV 0}

Table 1-4. Composition of K Basins Fuel and the Dose per Unit of Intake. (2 sheets)

\begin{tabular}{|c|c|c|}
\hline Radionuclide & $\begin{array}{c}\text { Activity } \\
(\text { Ci/MTU) }\end{array}$ & $\begin{array}{c}\text { CEDE per unit intake } \\
\text { rem/g }\end{array}$ \\
\hline${ }^{244} \mathrm{Cm}$ & $4.47 \mathrm{E}+00$ & $1.1 \mathrm{E}+03$ \\
\hline${ }^{55} \mathrm{Fe}$ & $5.41 \mathrm{E}-01$ & $1.5 \mathrm{E}-03$ \\
\hline${ }^{63} \mathrm{Ni}$ & $3.47 \mathrm{E}+00$ & $2.2 \mathrm{E}-02$ \\
\hline${ }^{79} \mathrm{Se}$ & $6.54 \mathrm{E}-02$ & $6.4 \mathrm{E}-04$ \\
\hline${ }^{93} \mathrm{Zr}$ & $2.95 \mathrm{E}-01$ & $9.5 \mathrm{E}-02$ \\
\hline${ }^{93 \mathrm{~m}} \mathrm{Nb}$ & $1.93 \mathrm{E}-01$ & $5.6 \mathrm{E}-02$ \\
\hline${ }^{106} \mathrm{Ru}^{\mathrm{c}}$ & $2.56 \mathrm{E}-02$ & $1.2 \mathrm{E}-02$ \\
\hline${ }^{107} \mathrm{Pd}$ & $1.56 \mathrm{E}-02$ & $2.0 \mathrm{E}-04$ \\
\hline${ }^{121 m} \mathrm{Sn}^{\mathrm{c}}$ & $6.27 \mathrm{E}-02$ & $7.2 \mathrm{E}-04$ \\
\hline${ }^{126} \mathrm{Sn}^{\mathrm{c}}$ & $1.29 \mathrm{E}-01$ & $1.3 \mathrm{E}-02$ \\
\hline${ }^{129} \mathrm{I}$ & $5.16 \mathrm{E}-03$ & $9.0 \mathrm{E}-04$ \\
\hline${ }^{135} \mathrm{Cs}^{144} \mathrm{Ce}$ & $6.04 \mathrm{E}-02$ & $2.8 \mathrm{E}-04$ \\
\hline${ }^{244} \mathrm{Cm}$ & $7.91 \mathrm{E}-04$ & $3.0 \mathrm{E}-04$ \\
\hline${ }^{\mathrm{Total}}$ & $4.47 \mathrm{E}+00$ & $1.1 \mathrm{E}+03$ \\
\hline
\end{tabular}

"Combined K Basins inventories decayed to May 31, 1998: $1.0 \mathrm{Ci}=3.7 \times 10^{10} \mathrm{~Bq}$.

'Fifty-year committed effective dose equivalent. The total was calculated by spreadsheet retaining three significant figures.

The following short-lived progeny nuclides are not shown in the table: ${ }^{90} \mathrm{Y},{ }^{137 \mathrm{~m}} \mathrm{Ba},{ }^{105} \mathrm{Rh}_{3}{ }^{121} \mathrm{Sn},{ }^{126 \mathrm{~m}} \mathrm{Sb}$, ${ }^{144 \mathrm{~m}} \mathrm{Pr},{ }^{144} \mathrm{Pr},{ }^{231} \mathrm{Th},{ }^{234} \mathrm{Th},{ }^{233} \mathrm{~Pa},{ }^{234} \mathrm{~Pa},{ }^{23440} \mathrm{~Pa},{ }^{237} \mathrm{U},{ }^{238} \mathrm{~Np},{ }^{242} \mathrm{Am}$, and ${ }^{242} \mathrm{Cm}$. These nuclides are found in secular equilibrium with the parent nuclide. Their dose contributions are included in the CEDE value shown for the parent nuclide.

MTU = metric ton of uranium.

$\mathrm{CEDE}=$ committed effective dose equivalent. 
$4.38 \times 10^{5} \mathrm{rem} / \mathrm{g}$. The values shown for the committed effective dose equivalent are the product of the activity and the dose conversion factor found in EPA Federal Guidance Report Number 11, Limiting Values of Radionuclide Intake and Air Concentration and Dose Conversion Factors for Inhalation, Submersion, and Ingestion. The dose conversion factor for tritium was increased by $50 \%$ to account for skin absorption (ICRP Publication 30). The committed effective dose equivalent for ${ }^{85} \mathrm{Kr}$ is the submersion dose factor from EPA Federal Guidance Report Number 12, Manual of Protective Action Guides and Protective Actions for Nuclear Incidents, divided by the light activity breathing rate.

\subsubsection{Risk Guidelines}

The U.S. Department of Energy-recommended radiological risk evaluation guidelines (Sellers 1997) are shown in Table 1-5. These criteria for identifying safety-class structures, systems, and components implement the guidance of DOE Order 6430.1A, General Design Criteria, Section 1300-1.4, "Guidance on Limiting Exposure of the Public," and are consistent with the graded approach to safety required by DOE Order 5480.23 .

As stated in HNF-PRO-704, satisfaction of its radiological evaluation guidelines meet the goals of SEN-35-91, Nuclear Safety Policy. However, the guidelines used by the SNF Project (Sellers 1997) are more conservative and are bounded by the guidelines specified in HNF-PRO-704, Table D-1. As such, satisfaction of the SNF Project radiological evaluation guidelines (Sellers 1997) will meet the goals of SEN-35-91. As discussed in future sections, the mitigated DBAs using the identified preventive and mitigative structure, system, and component features met the SNF Project radiological evaluation guidelines (Sellers 1997) and, consequently, the goals of SEN-35-91.

Table 1-5. Radiological Evaluation Guidelines and Limits.

\begin{tabular}{|l|c|c|c|}
\hline \multicolumn{1}{|c|}{ Event category } & $\begin{array}{c}\text { Frequency range } \\
\text { (per year) }\end{array}$ & $\begin{array}{c}\text { Onsite risk } \\
\text { evaluation } \\
\text { guidelines* } \\
\text { rem }\end{array}$ & $\begin{array}{c}\text { Offsite accident } \\
\text { release limits* } \\
\text { rem }\end{array}$ \\
\hline Anticipated & $1.0 \mathrm{E}-01$ to $1.0 \mathrm{E}-02$ & $1(5)$ & $0.5(0.5)$ \\
\hline Unlikely & $1.0 \mathrm{E}-02$ to $1.0 \mathrm{E}-04$ & $10(25)$ & $5.0(5)$ \\
\hline Extremely unlikely & $1.0 \mathrm{E}-04$ to $1.0 \mathrm{E}-06$ & $25(100)$ & $5.0(25)$ \\
\hline
\end{tabular}

Note: All doses are committed effective dose equivalents.

*This terminology is consistent with Tables I and 2 of Sellers, E. D., 1997, Risk Evaluation Guidelines (REGs) to Ensure Inherently Safer Designs (Letter 97-SFD-172 to H. J. Hatch, Fluor Daniel Hanford, Incorporated, August 26), U.S. Department of Energy, Richland Operations Office, Richland, Washington. These SNF Project guidelines are more conservative than the values in HNF-PRO-705, Safety Basis Planning, Documentation, Review, and Approval, Fluor Daniel Hanford, Incorporated, Richland, Washington (shown in parentheses). 


\subsubsection{Limiting Design Basis Accident Assumptions}

Based on limiting values assumed in the hazard and DBA analyses, the interface between the CVDF and the CSB requires that an MCO delivered from the CVDF to the CSB contain less than $200 \mathrm{~g}$ of free water and confine combustible hydrogen gases within the mechanically sealed MCOs. In addition, the CSB hazard and DBA analyses rely on the interface between the $\mathrm{K}$ Basins facility and the CVDF that requires the SNF delivered from the K Basins to the CVDF and the CSB to be sufficiently clean fuel (i.e., with cladding surfaces sufficiently free of aluminum hydroxides, uranium hydrides, uranium dioxides, and other surface contaminants) and the fuel loading to be controlled (e.g., the number of scrap baskets loaded into each MCO). The assumptions associated with the $\mathrm{K}$ Basins and CVDF performance are identified in Table 1-6. Safety-related performance documentation from the $\mathrm{K}$ Basins and the CVDF is relied on to ensure that the as-received content and condition of the MCO is as required for safety basis properties. 
Table 1-6. Key K Basins and Cold Vacuum Drying Facility Performance Assumptions.

\begin{tabular}{|c|c|c|c|}
\hline Facility & Performance parameter & \multicolumn{2}{|c|}{ Parameter } \\
\hline \multirow[t]{2}{*}{ K Basins } & \multirow[t]{2}{*}{$\begin{array}{l}\text { Maximum mass of aluminum hydroxide in an } \mathrm{MCO} \\
\text { delivered to the CSB }\end{array}$} & Value & $\begin{array}{c}\text { Equivalent } \\
\text { Water } \\
\text { Mass }\end{array}$ \\
\hline & & $48 \mathrm{~kg}^{*}$ & $16.8 \mathrm{~kg}^{*}$ \\
\hline K Basins & $\begin{array}{l}\text { Maximum mass of uranium hydrates in an } \mathrm{MCO} \\
\text { delivered to the CSB }\end{array}$ & $21.9 \mathrm{~kg}$ & $1.19 \mathrm{~kg}$ \\
\hline K Basins & $\begin{array}{l}\text { Maximum number of scrap baskets in an MCO } \\
\text { delivered to the CSB }\end{array}$ & $\begin{array}{l}2 \text { scrap } \\
\text { baskets }\end{array}$ & NA \\
\hline K Basins & $\begin{array}{l}\text { Maximum removable, not strongly adherent, } \mathrm{UO}_{2} \\
\text { particulate in an MCO delivered to the CSB }\end{array}$ & $\begin{array}{c}34 \mathrm{~kg} \text { of } \\
\mathrm{UO}_{2} \\
\text { particulate }\end{array}$ & NA \\
\hline CVDF & $\begin{array}{l}\text { Maximum free water in an MCO delivered to the } \\
\text { CSB }\end{array}$ & $200 \mathrm{~g}$ & $200 \mathrm{~g}$ \\
\hline CVDF & Leak rate of internal gas from $\mathrm{MCO}$ & $\begin{array}{c}<10^{-5} \\
\text { standard } \\
\mathrm{cm}^{3} / \mathrm{s}\end{array}$ & NA \\
\hline $\mathrm{CSB}$ & $\begin{array}{l}\text { Quantities of water moisture introduced into the } \\
\text { MCO during sampling operations do not exceed } \\
\text { "equivalent water mass" from aluminum hydroxide } \\
\text { and uranium hydrates in an MCO delivered to the } \\
\text { CSB per above }\end{array}$ & & \\
\hline
\end{tabular}

*This is the maximum based on long-term radiolysis; the thermal runaway case uses the HNF-SD-SNF-TI-015, 1997, Spent Nuclear Fuel Project Technical Databook, Rev. 0, Rev. 2 and ECN 645061, Fluor Daniel Hanford, Incorporated, Richland, Washington, value of $10.65 \mathrm{~kg}$ $\mathrm{Al}(\mathrm{OH})_{3}$ which corresponds to $3.73 \mathrm{~kg}$ water.

$\mathrm{CSB}=$ Canister Storage Building. $\mathrm{CVDF}=$ Cold Vacuum Drying Facility . $\mathrm{MCO}=$ multi-canister overpack. 
SNF-3328 REV 0

\subsection{REFERENCES}

DOE Order 5480.23, 1992, Nuclear Safety Analysis Reports, U.S. Department of Energy, Washington, D.C.

DOE Order 6430.1A, 1989, General Design Criteria, U.S. Department of Energy, Washington, D.C.

DOE/RL-94-02, 1995, Hanford Emergency Response Plan, U.S. Department of Energy, Richland Operations Office, Richland, Washington.

DOE-STD-3009-94, 1994, Preparation Guide for U.S. Department of Energy Nonreactor Nuclear Facility Safety Analysis Reports, U.S. Department of Energy, Washington, D.C.

EPA Federal Guidance Report Number 11, 1988, Limiting Values of Radionuclide Intake and Air Concentration and Dose Conversion Factors for Inhalation, Submersion, and Ingestion, EPA-520/1-88-020, U.S. Environmental Protection Agency, Washington, D.C.

EPA Federal Guidance Report Number 12, 1992, Manual of Protective Action Guides and Protective Actions for Nuclear Incidents, U.S. Environmental Protection Agency, Washington, D.C.

Hey, B. E., 1995, Revision 1 to Supporting Calculations for K Basin ISB (Internal Memo 8D150-BEH-94-003 R1 to J. R. Brehm, June 12), Westinghouse Hanford Company, Richland, Washington.

HNF-3048, 1998, Post Fuel-Cleaning Corrosion of Uranium Within MCO Payloads, Rev. 0, Fluor Daniel Hanford, Incorporated, Richland, Washington.

HNF-PRO-704, Hazard and Accident Analysis Process, Fluor Daniel Hanford, Incorporated, Richland, Washington.

HNF-PRO-705, Safety Basis Planning, Documentation, Review, and Approval, Fluor Daniel Hanford, Incorporated, Richland, Washington.

HNF-SD-SNF-CM-001, 1997, Spent Nuclear Fuel Project Configuration Monagement Plan, Rev. 2, Fluor Daniel Hanford, Incorporated, Richland, Washington.

HNF-SD-SNF-HIE-001, 1998, Canister Storage Building Hazard Analysis Report, Rev. 1, Fluor Daniel Hanford, Incorporated, Richland, Washington.

HNF-SD-SNF-TI-009, 1998, 105-K Basin Material Design Basis Feed Description for Spent Nuclear Fuel Project Facilities, Rev. 1, Fluor Daniel Hanford, Incorporated, Richland, Washington. 
HNF-SD-SNF-TI-015, 1997, Spent Nuclear Fuel Project Technical Databook, Rev. 0, Rev. 2 and ECN 645061, Fluor Daniel Hanford, Incorporated, Richland, Washington.

HNF-SD-SNF-TI-059, 1998, A Discussion on the Methodology for Calculating Radiological and Toxicological Consequences for the Spent Nuclear Fuel Project at the Hanford Site, Rev. 1, Fluor Daniel Hanford, Incorporated, Richland, Washington.

ICRP Publication 30, 1979, Limits for Intake by Workers, International Commission on Radiological Protection, Elmsford, New York.

NRC Regulatory Guide 1.145, 1982, Atmospheric Dispersion Models for Potential Accident Consequence Assessments at Nuclear Power Plants, U.S. Nuclear Regulatory Commission, Washington, D.C.

Sellers, E. D., 1996, Clarification of Site Boundary for Spent Nuclear Fuel Project (SNFP) Work in or Near K Basins (Letter 96-SFD-113 to President, Westinghouse Hanford Company, May 22), U.S. Department of Energy, Richland Operations Office, Richland, Washington.

Sellers, E. D., 1997, Risk Evaluation Guidelines (REGs) to Ensure Inherently Safer Designs (Letter 97-SFD-172 to H. J. Hatch, Fluor Daniel Hanford, Incorporated, August 26), U.S. Department of Energy, Richland Operations Office, Richland, Washington.

SEN-35-91, 1991, Nuclear Safety Policy, U.S. Department of Energy, Washington, D.C.

WHC-SD-GN-SWD-30002, 1995, GXQ Program Users' Guide, Rev. 1, Westinghouse Hanford Company, Richland, Washington.

WHC-SD-GN-SWD-30003, 1995, GXQ Program Verification and Validation, Rev. 1, Westinghouse Hanford Company, Richland, Washington. 
SNF-3328 REV 0

This page intentionally left blank. 


\subsection{REARRANGEMENT OF MULTI-CANISTER OVERPACK INTERNALS}

\subsection{PURPOSE AND OBJECTIVES}

If the multi-canister overpack (MCO) were to be subjected to an accidental drop, impact, or shear force of sufficient magnitude, then the MCO or the cask-MCO could be damaged in such a way as to breach the MCO or to substantially rearrange its internal geometry. A number of potential accidents have been identified at the Canister Storage Building (CSB) and are listed in Section 2.2. Five of these accidents are selected for further discussion or evaluation. While some of the cases could lead to radiological dose consequences or to a violation of criticality geometry control criteria, these scenarios are either prevented or mitigated so that no violation or significant release may occur, or are determined to occur so infrequently $\left(<10^{-6} / \mathrm{yr}\right)$ that they do not need to be considered. These cases are prevented or significantly mitigated by design and control features associated with the CSB or MCO handling machine (MHM). Required controls for each accident are summarized in Section 2.6.

\subsection{SCENARIO DEVELOPMENT}

At the CSB the MCO is hoisted by both the receiving crane and the MHM. The MCO could be dropped, either when it is inside the transportation cask or when it is outside the cask. Objects (e.g., the transportation cask lid) are also hoisted above the MCO, creating the potential for a drop onto the MCO. Other building equipment could move and collide with the MCO or the transportation cask. Several different scenarios that could cause rearrangement of MCO internals were considered, all of which were considered potentially serious hazards to the $\mathrm{MCO}$ in the CSB hazard analysis (HNF-SD-SNF-HIE-001). These scenarios include the following:

- Cask-MCO drop from the receiving crane

- Cask lid drop onto the MCO

- Drop of an MCO by the MHM

- Shear of an MCO by the MHM.

The translational movement of the CSB receiving crane and the MHM and the rotational movement of the MFM turret provide mechanisms for applying lateral or shear forces to the side of the MCO. These shear forces could be applied when the MCO extends across two regions that can translate or rotate with respect to one another, such as when the MCO is partially lowered below the CSB deck into a storage tube or partially lowered below the MHM turret-base interface. Rotational or translational forces could be applied to the MCO by the MHM because of operator error, MHM malfunction or failure, or an earthquake. An accident in which lateral forces are applied to the MCO, resulting in possible breach of confinement and loss of criticality geometry control of the fuel, is considered to be the bounding impact force design basis accident for the accident grouping involving the rearrangement of MCO internals. 


\section{SNF-3328 REV 0}

MCO containment and geometry must not be allowed to be breached or significantly altered because an $\mathrm{MCO}$ provides both primary containment and nuclear criticality configuration control of the spent nuclear fuel. Equipment or controls that protect the $\mathrm{MCO}$ and prevent violations of criticality limits are considered safety class (HNF-PRO-704, DOE Order 6430.1A). Because such equipment and controls must be designated safety class, it is not necessary to perform radiological consequence analysis for accidents that could violate criticality limits. Dose consequence analysis could not prescribe more stringent safety classifications than those already required to protect the $\mathrm{MCO}$ and to protect against criticality contingencies.

An MCO must continue to meet several conditions during any drop, impact or shear accident. Three geometry constraints must be satisfied to maintain criticality control: (1) the axis of the basket center criticality insert (6.6-in. pipe) must be maintained within 2 in. of the MCO centerline, (2) the inside MCO circumference must not exceed 73.04 in., and (3) the spent nuclear fuel contents in the MCO must be maintained within the MCO (HNF-SD-SNF-CSER-005). Because the MCO does not contain significant water while at the CSB, a criticality will not occur because any or all of these geometry controls are violated (double contingency is satisfied).

All MCO lateral force (shear) accidents with potentially unacceptable consequences have been prevented by safety-class MHM interlock controls. A discussion of the MHM interlocks is included in HNF-3553, Spent Nuclear Fuel Project Final Safety Analysis Report, Annex A, "Canister Storage Building Final Safety Analysis Report," Chapter A4.0, "Safety Structures, Systems, and Components."

A shear of an MCO by the MHM was identified in the CSB hazard analysis (HNF-SD-SNF-HIE-001) as a potentially significant accident (designator: SA-E-07, SA-F-07b, OA-E-07, OA-F-07, WS-E-07, WS-F-07). Because such an accident has the potential to cause the most damage to an $\mathrm{MCO}$ in terms of its fuel confinement and containment safety functions, it is considered to bound the consequences of all other accidents that could rearrange the MCO internals. Shear forces could be applied to the MCO during an unmitigated accident by MHM rotational or translational movement due to operator error, MHM malfunction or failure, or a seismic event. It is also postulated that the turret rotation could shear the MCO hoist cable and result in a drop of the MCO. Neither of these turret rotation accidents can occur unless one of several safety-class MHM interlocks (P6, P80, P9) is defeated. MHM interlock P9 ensures that the turret seismic restraints are applied prior to operating the MCO hoist. MHM interlocks P6 and P80 ensure that the turret seismic restraints cannot be disengaged and that power is not supplied to the turret rotate motor unless the MCO is fully raised in the MHM. Shear of an MCO by the MHM may be possible during a seismic event if the $\mathrm{MCO}$ is partially inserted in a storage tube, a pit, or the transport cask. Lateral movement of the massive MHM during a design basis earthquake could shear the MCO. Seismic restraints on the MHM trolley and gantry will prevent significant lateral movement when the restraints are applied. The MHM could also apply significant lateral forces against an MCO if the bridge or trolley drives were activated by operator error or MHM malfunction while the MCO is partially lowered from the MHM. MHM interlock P21 prevents the raising or lowering of the MCO hoist unless the bridge and trolley seismic restraints are applied. MHM interlocks (P3, P6, P8, P26, P80) prevent the disengagement of the 
bridge and turret seismic restraints and internupts bridge and trolley drive motor power unless the MCO is fully raised.

Consistent with credible drop scenarios developed from the CSB hazard analysis, $\mathrm{MCO}$ and cask-MCO drop analyses have been performed for different conceivable drop events. These analyses have been performed for a representative set of identified drop events that are not prevented by safety features. Drop event analyses have been performed for different orientations of the MCO (or dropped object) and assuming different material properties to ensure that the calculated effects of the drop events were thoroughly investigated and well understood. To demonstrate that all possible drop/shear scenarios have been considered and either explicitly analyzed or bounded by similar analyzed events, each process step during the MCO lifetime at the CSB is chronologically listed in Table 2-1 with any considered drop/shear scenarios. Drop accident scenarios that could occur during transportation to or from the CSB are discussed in HNF-SD-TP-SARP-017, Safety Analysis Report for Packaging, Onsite, Multicanister Overpack Cask.

\subsubsection{Cask-Multi-Canister Overpack Drop from Receiving Crane}

Conceivable cask-MCO drop events from the receiving crane were identified in the CSB hazard analysis (HNF-SD-SNF-HIE-001) as potential significant accidents (designator: TV-G-09, TV-G-13, SA-G-03b). The CSB receiving crane has been designated a safety-significant and important-to-safety piece of equipment. The crane only provides a single-load path but is rated for twice the load required for a safety-significant hoist. The crane is used to lift the cask-MCO from the transport trailer using a yoke. The crane is then translated to place the cask-MCO above the service station pit and the cask-MCO is lowered into the pit. The cask-MCO could be dropped from the receiving crane at any location the crane travels while suspending the cask-MCO. Drops 3 through 8, listed in Table 2-1, represent each distinct drop event possible during a receiving crane operation. Any of these drop events could occur due to a failure in the lift system (e.g., the hook, hoist rope, cask yoke) or as a result of improper connections of the load to the hoist. Because the crane is designed to ASME NOG-1, Rules for Construction of Overhead and Gantry Cranes (Top Running Bridge, Multiple Girder), Type I, criteria, the crane load should remain suspended during and after a design basis earthquake event. The drop from the receiving crane that impacts the transporter and results in a horizontal slap-down of the cask-MCO onto the concrete receiving area is the bounding unmitigated scenario for all possible receiving crane drops and provides the bounding unmitigated consequences. Recently, however, the SNF Project has implemented a prevention system for this drop. The cask transfer safety system is designed to prevent a dropped cask-MCO from impacting the floor during offloading from the transport trailer. The absorbing material collapses if a cask is dropped on it and cushions the cask. The restraints prevent the cask from tipping and falling on its side (slap down) in an unlikely event that the cask is dropped. The cask transfer safety system provides protection for the cask- $\mathrm{MCO}$ as it is being transferred from the transporter to the receiving pit. Other drops from the receiving crane that could have worse consequences have been reduced in frequency sufficiently to claim that they have been prevented. 
Table 2-1. Multi-Canister Overpack Process Steps and Possible Drop, Shear, or Impact Scenarios. (5 sheets)

\begin{tabular}{|c|c|c|c|c|c|c|c|}
\hline $\begin{array}{l}\text { Drop } \\
\text { shear }\end{array}$ & $\begin{array}{c}\text { Process step or } \\
\text { event }\end{array}$ & Drop/shear/impact description & Credible & Analyzed & $\begin{array}{c}\text { MCO } \\
\text { fail }\end{array}$ & Prevented & Safety controls, consequences, and comments \\
\hline 1 & $\begin{array}{l}\text { Cask-MCO } \\
\text { transported to } \\
\text { CSB }\end{array}$ & $\begin{array}{l}\text { See the safety analysis report for } \\
\text { packaging }^{\mathrm{a}}\end{array}$ & & & & & See the safety analysis report for packaging." \\
\hline 2 & $\begin{array}{l}\text { Remove } \\
\text { tractor }\end{array}$ & None & $\mathrm{N}$ & & & & NA \\
\hline 3 & \multirow{7}{*}{$\begin{array}{l}\text { Cask-MCO } \\
\text { moved by the } \\
\text { receiving crane } \\
\text { to the MCO } \\
\text { service station } \\
\text { pit }\end{array}$} & $\begin{array}{l}\text { Cask-MCO drop onto trailer edge } \\
\text { with horizontal slap-down onto } \\
\text { floor. Drop height: } 40 \mathrm{in} .\end{array}$ & $\mathrm{Y}$ & $\mathrm{Y}$ & $\mathrm{N}$ & $\mathrm{Y}$ & Cask transfer safety system. ${ }^{b}$ \\
\hline 4 & & $\begin{array}{l}\text { Cask-MCO vertical drop directly } \\
\text { onto concrete floor }\end{array}$ & $\mathbf{Y}$ & $\mathrm{Y}$ & $\mathbf{N}$ & $\mathrm{Y}$ & Cask transfer safety system. . $^{c}$ \\
\hline 5 & & $\begin{array}{l}\text { Cask-MCO drop onto edge of } \\
\text { service pit with slap-down }\end{array}$ & $\mathrm{Y}$ & $\mathrm{Y}$ & $\mathbf{N}$ & $\mathrm{N}$ & $\begin{array}{l}\text { The consequences for this drop are bounded by analyses } \\
\text { for the drop onto trailer edge with horizontal slap-down } \\
\text { (drop 3). }\end{array}$ \\
\hline 6 & & Cask-MCO drop into service pit & $\mathrm{Y}$ & $\mathrm{Y}$ & $\mathrm{N}$ & $\mathrm{N}$ & $\begin{array}{l}\text { This drop is not expected to violate MCO containment or } \\
\text { criticality geometry control. }\end{array}$ \\
\hline 7 & & $\begin{array}{l}\text { Cask-MCO shear by moving } \\
\text { receiving crane while partially } \\
\text { lowered into pit }\end{array}$ & $\mathrm{Y}$ & $\mathrm{Y}$ & $\mathrm{N}$ & $\mathrm{N}$ & $\begin{array}{l}\text { Shear forces not sufficient to significantly damage the } \\
\text { MCO because of the transportation cask. }\end{array}$ \\
\hline 8 & & $\begin{array}{l}\text { Cask-MCO drop onto edge of } \\
\text { maintenance pit with horizontal } \\
\text { slap-down into pit floor }\end{array}$ & $\mathrm{Y}$ & $\mathrm{N}$ & $\mathrm{Y}$ & $\mathrm{Y}$ & $\begin{array}{l}\text { This drop could lead to a } 2 \text { in, deflection of the MCO } \\
\text { center tube, violating a criticality safety criteria. A } \\
\text { resolver and interlock on receiving crane movement will } \\
\text { prevent this event. }\end{array}$ \\
\hline 9 & & $\begin{array}{l}\text { MHM shears the MCO by colliding } \\
\text { with the crane and cask-MCO as } \\
\text { the cask-MCO is lowered into the } \\
\text { pit }\end{array}$ & $\mathrm{Y}$ & $\mathrm{N}$ & $\mathrm{N}$ & $\mathrm{Y}$ & $\begin{array}{l}\text { Interlocks do not allow the MHM to enter the service area } \\
\text { while the receiving crane is present. Analysis } \\
\text { demonstrates that, in this accident, the transportation cask } \\
\text { prevents unacceptable MCO damage. }\end{array}$ \\
\hline
\end{tabular}




\begin{tabular}{|c|c|c|c|c|c|c|c|}
\hline $\begin{array}{l}\text { Drop } \\
\text { shear }\end{array}$ & $\begin{array}{c}\text { Process step or } \\
\text { event }\end{array}$ & Drop/shear/impact description & Credible & Analyzed & $\begin{array}{c}\mathrm{MCO} \\
\text { fail }\end{array}$ & Prevented & Safety controls, consequences, and comments \\
\hline 10 & $\begin{array}{l}\text { Cask yoke } \\
\text { removal }\end{array}$ & Drop yoke onto cask lid & $\mathbf{Y}$ & $\mathrm{N}$ & $\mathrm{N}$ & $\mathrm{N}$ & Insufficient force to damage MCO through cask lid. \\
\hline 11 & $\begin{array}{l}\text { Cask lid } \\
\text { removal using } \\
\text { service station } \\
\text { gantry hoist }\end{array}$ & Drop cask lid onto MCO & $\mathrm{Y}$ & $\mathrm{Y}$ & $\mathrm{N}$ & $\mathbf{N}$ & $\begin{array}{l}\text { Analysis of this drop demonstrates that the structural } \\
\text { containment of the MCO is not breached and that } \\
\text { criticality geometry control is not compromised. } \\
\text { port cover-to-flange seal may be broken. If the rupture } \\
\text { disk were to release from over-pressurization, an MCO } \\
\text { blow-down could occur. }\end{array}$ \\
\hline 12 & Seismic event & CSB facility structure falls on MCO & $\mathbf{N}$ & $\mathrm{N}$ & $\mathbf{Y}$ & $\mathbf{Y}$ & $\begin{array}{l}\text { The CSB facility is seismically qualified. This drop is } \\
\text { incredible. }\end{array}$ \\
\hline 13 & $\begin{array}{l}\text { Tent removal } \\
\text { and radiation } \\
\text { survey }\end{array}$ & None & $\mathbf{N}$ & $\mathrm{N}$ & $\mathrm{N}$ & NA & NA \\
\hline 14 & \multirow{4}{*}{$\begin{array}{l}\text { MCO retrieved } \\
\text { from cask in } \\
\text { service pit into } \\
\text { the } \mathrm{MHM}^{\mathrm{B}}\end{array}$} & Drop service pit plug onto MCO & $\mathbf{N}$ & $\mathrm{N}$ & $\mathrm{N}$ & $\mathbf{Y}$ & $\begin{array}{l}\text { The design of plug and pit shield make it geometrically } \\
\text { impossible for this drop to impact the MCO. }\end{array}$ \\
\hline 15 & & Drop MCO onto edge of cask & $\mathbf{N}$ & $\mathrm{Y}$ & $\mathrm{N}$ & $\mathrm{Y}$ & $\begin{array}{l}\text { This drop is not expected to violate MCO containment or } \\
\text { criticality geometry control. } .^{\circ} \text { Drop likelihood is reduced } \\
\text { by MHM interlocks (P61, P62, P66) and grapple design. }\end{array}$ \\
\hline 16 & & $\begin{array}{l}\text { Drop MCO back into cask. Could } \\
\text { be caused by shear of MCO hoist by } \\
\text { improper turret rotation }\end{array}$ & $\mathrm{N}$ & $\mathrm{Y}$ & $\mathrm{N}$ & $\mathrm{Y}$ & $\begin{array}{l}\text { This drop is not expected to violate MCO containment or } \\
\text { criticality geometry control." Drop likelihood is reduced } \\
\text { by MHM interlocks (P61, P62, P66) and grapple design. } \\
\text { Consequences of a drop from shear of hoist are bounded } \\
\text { by drop } 11 \text {. }\end{array}$ \\
\hline 17 & & $\begin{array}{l}\text { Shear MCO by moving MHM with } \\
\text { MCO only partially retrieved into } \\
\text { the MHM cask }\end{array}$ & $\mathrm{N}$ & $\mathrm{N}$ & $\mathrm{Y}$ & $\mathrm{Y}$ & $\begin{array}{l}\text { This shear is prevented by MHM SC interlocks (P3, P8, } \\
\text { P6, P9, P21, P26, P80). }\end{array}$ \\
\hline
\end{tabular}


Table 2-1. Multi-Canister Overpack Process Steps and Possible Drop, Shear, or Impact Scenarios. (5 sheets)

\begin{tabular}{|c|c|c|c|c|c|c|c|}
\hline $\begin{array}{l}\text { Drop } \\
\text { shear }\end{array}$ & $\begin{array}{c}\text { Process step or } \\
\text { event }\end{array}$ & Drop/shear/impact description & Credible & Analyzed & $\begin{array}{c}\mathrm{MCO} \\
\text { fail }\end{array}$ & Prevented & Safety controls, consequences, and comments \\
\hline 18 & \multirow[t]{2}{*}{ Seismic event } & $\begin{array}{l}\text { Shear MCO while partially inserted } \\
\text { into service station pit or storage } \\
\text { tube during a design basis } \\
\text { earthquake. }\end{array}$ & $\mathrm{Y}$ & $\mathbf{N}$ & Y & $\mathrm{Y}$ & $\begin{array}{l}\text { This shear is prevented by MHM SC seismic restraints } \\
\text { and SC interlocks (P3, P6, P8, P21, P26, P80). }\end{array}$ \\
\hline 19 & & $\begin{array}{l}\text { Cause MF-FM to fall onto operating } \\
\text { deck, resulting in major structural } \\
\text { damage to deck }\end{array}$ & $\mathrm{Y}$ & $\mathrm{Y}$ & $\mathrm{N}$ & $\mathrm{Y}$ & $\begin{array}{l}\text { This drop is prevented by the MHM seismic restraints and } \\
\text { SC interlocks (P3, P21) that ensure their operation. }\end{array}$ \\
\hline 20 & \multirow{3}{*}{$\begin{array}{l}\text { MCO } \\
\text { transported to } \\
\text { storage tube or } \\
\text { sampling/weld } \\
\text { station }\end{array}$} & $\begin{array}{l}\text { Shear MCO by rotating turret with } \\
\text { MCO only partially retracted into } \\
\text { M-M cask }\end{array}$ & $\bar{Y}$ & $\mathrm{~N}$ & $\mathrm{~N}$ & $Y$ & $\begin{array}{l}\text { This shear is prevented by MHM SC interlocks (P9, P6, } \\
\text { P80). }\end{array}$ \\
\hline 21 & & $\begin{array}{l}\text { Drop MCO within MHM MCO } \\
\text { cask tube onto MHMM turret deck }\end{array}$ & $\mathrm{Y}$ & $\mathrm{N}$ & $\mathrm{N}$ & $\mathrm{Y}$ & $\begin{array}{l}\text { Drop likelihood is reduced by MHM interlocks (P61, } \\
\text { P62, P66) and grapple design. Consequences bounded by } \\
\text { drop } 28 \text {. }\end{array}$ \\
\hline 22 & & $\begin{array}{l}\text { Drop MCO onto CSB deck or over } \\
\text { empty tubes or over empty pits (i.e., } \\
\text { maintenance pit, exchange facility } \\
\text { pit) }\end{array}$ & $\mathrm{Y}$ & $\mathrm{N}$ & $\mathrm{Y}$ & $\mathrm{Y}$ & $\begin{array}{l}\text { Drop into pits is prevented by MHM SC interlocks (P3, } \\
\text { P8, P26, P85, P80) and grapple design. }\end{array}$ \\
\hline 23 & $\begin{array}{l}\text { Install } \\
\text { intermediate } \\
\text { impact } \\
\text { absorber on } \\
\text { MCO }\end{array}$ & $\begin{array}{l}\text { Drop limiter on MCO - reduce } \\
\text { limiter effectiveness }\end{array}$ & $\mathrm{Y}$ & $\mathrm{N}$ & $\mathrm{N}$ & $\mathrm{Y}$ & $\begin{array}{l}\text { Drop likelihood is reduced by MHM interlocks (P61, } \\
\text { P62, P66) and grapple design. Limiter effectiveness } \\
\text { should not be greatly reduced. }\end{array}$ \\
\hline 24 & \multirow[t]{2}{*}{$\begin{array}{l}\text { MCO placed } \\
\text { in storage tube } \\
\text { or } \\
\text { sampling/weld } \\
\text { station }\end{array}$} & $\begin{array}{l}\text { Shear MCO or MHM grapple cable } \\
\text { by translating MHM with MCO } \\
\text { only partially deployed into the } \\
\text { storage tube }\end{array}$ & $\mathrm{Y}$ & $\mathbf{N}$ & $\mathrm{Y}$ & $\mathrm{Y}$ & $\begin{array}{l}\text { This shear is prevented by MHM SC interlocks (P3, P8, } \\
\mathrm{P6}, \mathrm{P} 21, \mathrm{P} 26, \mathrm{P} 80 \text { ). }\end{array}$ \\
\hline 25 & & $\begin{array}{l}\text { Shear MCO by rotating MHOM } \\
\text { turret with MCO only partially } \\
\text { retracted into MHM cask }\end{array}$ & $\mathrm{Y}$ & $\mathrm{N}$ & $\mathrm{N}$ & $\mathrm{Y}$ & $\begin{array}{l}\text { This shear is prevented by MHM SC interlocks (P6, P9, } \\
\mathrm{P} 80 \text { ). }\end{array}$ \\
\hline
\end{tabular}


SNF-3328 REV 0

\begin{tabular}{|c|c|c|c|c|c|c|c|c|c|}
\hline 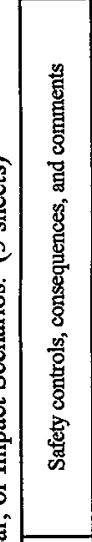 & 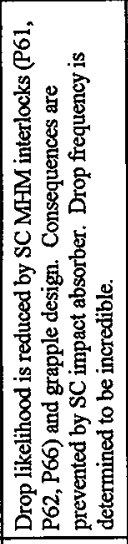 & 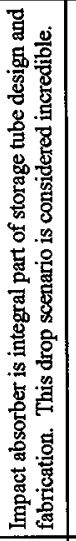 & 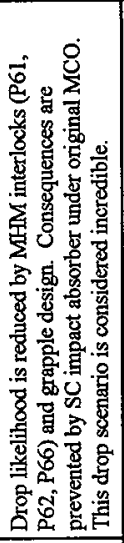 & 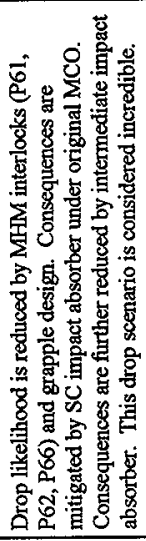 & 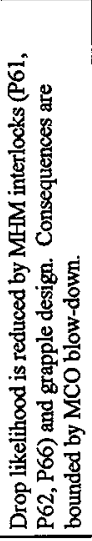 & 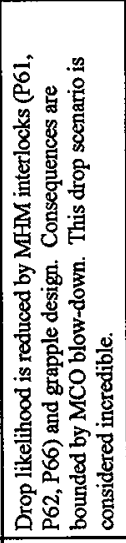 & 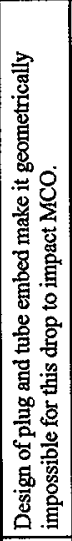 & 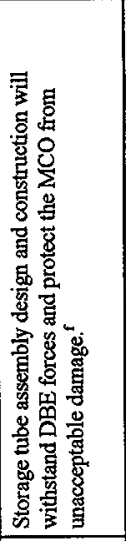 & 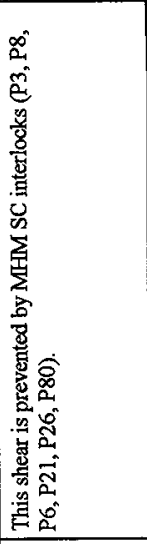 \\
\hline $\begin{array}{l}\text { 莺 } \\
\text { 总 } \\
\text { 总 }\end{array}$ & $\rightarrow$ & $\Rightarrow$ & $>$ & $\nu$ & 2 & $>-$ & $>$ & $>$ & $>$ \\
\hline 号富 & Z & $p$ & $>$ & $z$ & $>$ & $>$ & $z$ & z & $>$ \\
\hline$\frac{\mathrm{g}}{\mathrm{g}}$ & z & $z$ & $z$ & $z$ & z & $z$ & $z$ & $>$ & $z$ \\
\hline 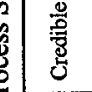 & $z$ & 学 & $\stackrel{\text { 兄 }}{ }$ & 学 & $>$ & $\ddot{z}$ & $z$ & 7 & $x$ \\
\hline 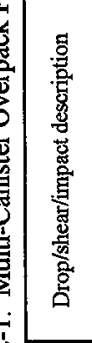 & 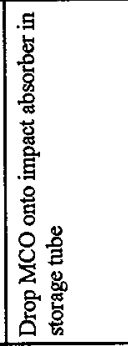 & 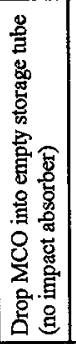 & 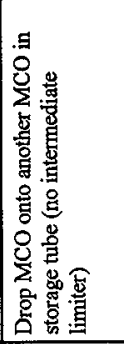 & 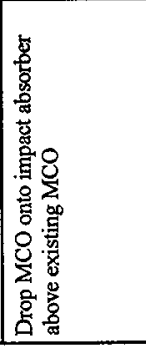 & 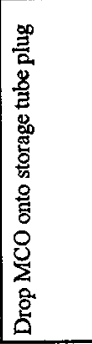 & 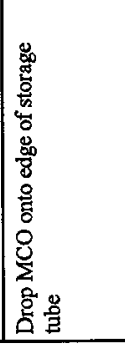 & 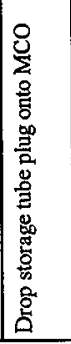 & 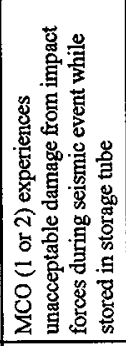 & 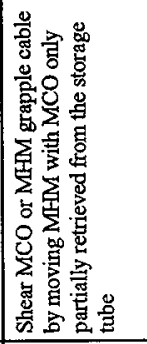 \\
\hline 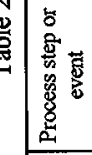 & & & & & & & & 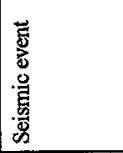 & 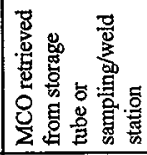 \\
\hline 总莍 & జ్రి & $\pi$ & $\stackrel{\infty}{\sim}$ & ते & 았 & $\bar{m}$ & N & $m$ & 志 \\
\hline
\end{tabular}


Table 2-1. Multi-Canister Overpack Process Steps and Possible Drop, Shear, or Impact Scenarios. (5 sheets)

\begin{tabular}{|l|c|l|c|c|c|c|c|}
\hline $\begin{array}{l}\text { Drop } \\
\text { shear }\end{array}$ & $\begin{array}{c}\text { Process step or } \\
\text { event }\end{array}$ & \multicolumn{1}{|c|}{ Drop/shear/impact description } & Credible & Analyzed & $\begin{array}{c}\text { MCO } \\
\text { fail }\end{array}$ & Prevented & Safety controls, consequences, and comments \\
\cline { 1 - 6 } & & $\begin{array}{l}\text { Shear MCO by rotating turret with } \\
\text { MCO only partially retracted into } \\
\text { MHM cask }\end{array}$ & $\mathrm{Y}$ & $\mathrm{N}$ & $\mathrm{N}$ & $\mathrm{Y}$ & $\begin{array}{l}\text { This shear is prevented by an MHM SC interlocks (P6, } \\
\mathrm{P} 9, \mathrm{P} 80) .\end{array}$ \\
\hline 36 & & $\begin{array}{l}\text { Drop MCO onto impact absorber in } \\
\text { storage tube }\end{array}$ & $\mathrm{N}^{\mathrm{s}}$ & $\mathrm{N}$ & $\mathrm{N}$ & $\mathrm{Y}$ & $\begin{array}{l}\text { Drop likelihood is reduced by MHM SC interlocks (P61, } \\
\text { P62, P66) and grapple design. Consequences are } \\
\text { prevented by SC impact absorber. This drop scenario is } \\
\text { considered incredible. }\end{array}$ \\
\hline 37 & & $\begin{array}{l}\text { Drop MCO onto a previously } \\
\text { crushed impact absorber (MCO } \\
\text { was dropped when originally } \\
\text { inserted) }\end{array}$ & $\mathrm{N}^{\mathrm{s}}$ & $\mathrm{N}$ & $\mathrm{Y}$ & $\mathrm{Y}$ & $\begin{array}{l}\text { Drop likelihood is reduced by MHM interlocks (P61, } \\
\text { P62, P66) and grapple design. Previously crushed impact } \\
\text { absorber may still provide some mitigation of MCO } \\
\text { damage. This drop scenario is considered incredible. }\end{array}$ \\
\hline
\end{tabular}

Note: MHM SC interlock descriptions may be found in HNF-3553, 1999, Spent Nuclear Fuel Project Final Safety Analysis Report, Annex A, "Canister Storage Building Final Safety Analysis Report," Chapter A4.0, "Safety Structures, Systems, and Components," Rev. 0, Fluor Daniel Hanford, Incorporated, Richland, Washington.

"HNF-SD-TP-SARP-017, 1997, Safety Analysis Report for Packaging, Onsite, Multicanister Overpack Cask, Rev. 0, Fluor Daniel Hanford, Incorporated, Richland, Washington.

'HNF-SD-SNF-DP-010, 1997, Cask and MCO Drop onto the Transport Trailer Edge with Subsequent Horizontal Slap Down onto the CSB Receiving Area Floor, Rev. 0, Fluor Daniel Hanford, Incorporated, Richland, Washington.

"HNF-SD-SNF-DP-007, 1997, Multi-Canister Overpack/Cask Drop Analysis File Documentation, Rev. 0, Fluor Daniel Hanford, Incorporated, Richland, Washington.

PPetersen, S. L. 1998, MHM Collision with CaskMCO (Transmittal FDT-137 to A. S. Daughtridge, D\&ES Hanford, November 30), Fluor Daniel, Incorporated, Richland, Washington.

"WHC-SD-SNF-DB-009, 1996, Storage Building Natural Phenomena Hazards, Rev. 4, Westinghouse Hanford Company, Richland, Washington.

'CSB-S-0007A, 1996, Storage Tube Analysis Confirmation, Fluor Daniel Hanford, Incorporated, Richland, Washington.

TThese drops were recentiy considered incredible per SNF-4087, The Frequency of a Multi-Canister Overpack (MCO) Drop by the Multi-Canister Overpack Handling Machine (MHM), Rev, 0, Fluor Daniel Hanford, Richland, Washington.

$\mathrm{DBE}=$ design basis earthquake.

$\mathrm{MCO}=$ multi-canister overpack.

MHM = multi-canister overpack handling machine

NA $=$ not applicable. 
A drop of the cask-MCO from a height of $40 \mathrm{in}$. with a subsequent slap-down onto the CSB receiving area concrete floor (drop 3 ) has been shown to result in no releases of radioactivity and no loss of criticality configuration control (HNF-SD-SNF-DP-010). The cask transfer safety system prevents or mitigates this drop.

The consequences of a cask-MCO drop by the receiving crane into the maintenance pit (drop 8, height greater than $40 \mathrm{in}$.) with a slap-down have not been determined. Based upon the results from a similar analysis (HNF-SD-SNF-DP-007), it is expected that such an accident would damage the MCO center tube geometry sufficiently to cause a criticality specification violation. While definitive supporting calculations do not exist, no radiological releases or associated onsite $(100 \mathrm{~m})$ or offsite dose consequences are expected from such an accident because of the structural protection provided by the cask. This accident frequency is reduced to beyond extremely unlikely by a safety-class receiving crane resolver and associated interlock. The resolver tracks the east-west position of the receiving crane. Before the receiving crane reaches the west side of the Fast Flux Test Facility (FFTF) pit, the interlock removes power from the drive motors. Power may only be restored to the crane by both the use of a supervisor-controlled fortress key at a remote station and the operator depressing an override button on the crane. While this interlock does not reduce the drop frequency, it does reduce the frequency of drops into the FFTF or maintenance pits. A technical safety requirement (TSR) program will not allow the interlock to be overridden when a cask-MCO is suspended by the crane.

\subsubsection{Cask Lid Drop onto Multi-Canister Overpack}

A drop of the cask lid onto the MCO was identified in the CSB hazard analysis (HNF-SD-SNF-HIE-001) as a potentially significant accident (designator: SA-G-03a). When the MCO transportation cask lid is removed from the cask, the lid could be dropped from the service station gantry hoist onto the top of the MCO or its port covers. While it has been demonstrated that such drops ( $5 \mathrm{ft}$ or less drop height) do not violate the structural integrity of the MCO (HNF-SD-SNF-DP-010, HNF-SD-SNF-DP-007), it is likely that the seal between the port cover and the MCO is ruptured. Below one port is a rupture disk. This disk is not expected to be disturbed by the drop. However, if the seal is broken on the MCO rupture disk port and the MCO pressurizes above the rupture disk relief pressure $(10 \mathrm{~atm})$, then a blow-down of the MCO would occur. The maximum internal MCO pressure at CSB is $5.2 \mathrm{~atm}$ (HNF-SD-SNF-TI-015). Over-pressurization of the $\mathrm{MCO}$ above the rupture disk relief pressure is considered incredible because insufficient water is available in the MCO to generate the required gas. It is not physically possible to lift the transportation cask lid more than $5 \mathrm{ft}$ above the MCO using the service station gantry hoist.

\subsubsection{Drop of a Multi-Canister Overpack by the Multi-Canister Overpack Handling Machine}

Drops of the MCO by the MHM were identified in the CSB hazard analysis

(HNF-SD-SNF-HIE-001) as potential significant accidents (designator: OA-G-03, -13, 
SA-G-03b, -13, WS-G-03a and b, -13). The safety-class interlocks on the MHM and the mechanics of the grapple associated with the MHM hoist combine to greatly reduce the likelihood that any MCO drop from the MHM will occur. MHM descriptions may be found in HNF-3553, Annex A, Chapter A2.0, "Facility Description." The MHM hoist has a single-failure-proof load path. The MHM grapple is designed with a mechanical lock that, when properly engaged, uses the weight of the MCO to help maintain a nearly fault-proof grip on the MCO. Interlocks prevent the grapple jaws from being opened unless the grapple is no longer loaded and the grapple is at a height corresponding to a permitted MCO set-down location (interlock P66). The most credible failure of this locking mechanism requires that the sensors that detect when the grapple has fully closed be miscalibrated, so that the grapple engages the MCO but does not engage its mechanical locking mechanism. Because the sensors are calibrated at the same time, miscalibration would be a common mode failure of this double-channel interlock. Even with this grapple interlock compromised, the MCO must be physically disturbed (possibly a seismic event) or another MHM interlock (such as P66) must fail and allow the operator to fully open the grapple under load before a drop would result. Recent calculations confirm that frequency of this drop is incredible $\left(<10^{-6} / \mathrm{yr}\right)(\mathrm{SNF}-4087)$.

Another possible accident that could lead to a drop is the shear of the MCO hoist cables by rotation of the MHM turret or by lateral movement of the MHM during a seismic event. Rotation of the turret while lowering the MCO is prevented by a safety-class interlock (P6). The MHM may not be rotated to the MCO hoist unless the MHM crane bridge and trolley seismic restraints have been applied (interlock P21). These seismic restraints prevent the MHM from shearing the hoist cables in a design basis earthquake. Drop of the $\mathrm{MCO}$ at a location other than a pit or tube where the MCO would normally be raised or lowered is considered incredible, because not only does the grapple and its interlocks have to fail but the interlock (P26), which prevents the turret from rotating and the turret seismic restraints disengaging without lowering the shield skirt, must also fail. Recent calculations confirm that frequency of this drop is incredible $\left(<10^{-6} / \mathrm{yr}\right)$ (SNF-4087).

Because drops into the service pit, sampling/weld station pit, or storage tube are not considered beyond extremely unlikely accidents, each of these locations are fitted with an impact absorber. These impact absorbers are required to limit the deceleration of a maximum weight MCO dropped from the maximum height to less than $35 \mathrm{~g}$. The MCO and internal baskets are designed to maintain confinement, containment, and subcriticality under all design basis drops with decelerations limited below $35 \mathrm{~g}$ (HNF-S-0426). These same MCO safety functions are maintained for some drops where this deceleration is exceeded. No consequence analyses are performed for any MCO drops from the MHM because they are all either incredible or their consequences have been mitigated such that no radiological release is expected.

\subsubsection{Shear of a Multi-Canister Overpack by the Multi-Canister Overpack Handling Machine}

A shear of an MCO by the MHM was identified in the CSB hazard analysis as a potentially significant accident (designator: SA-E-07, SA-F-07b, OA-E-07, OA-F-07, WS-E-07, WS-F-07) 
(HNF-SD-SNF-HIE-001). Because this accident has the potential to cause the most damage to an MCO in terms of its fuel confinement and containment safety functions, it is considered to bound the consequences of all other accidents that could rearrange the MCO internals. Simple analysis has demonstrated that the turret will not shear the MCO during rotation. It is also possible that the turret rotation could shear the MCO hoist cable and result in a drop of the MCO. Neither of these turret rotation accidents can occur unless one of several safety-class MHM interlocks $(\mathrm{P} 6, \mathrm{P} 80, \mathrm{P} 9)$ is defeated. MHM interlock $\mathrm{P} 9$ ensures that the turret seismic restraints, the base and the turret locking pins, are applied prior to operating the MCO hoist. MHM interlocks P6 and P80 ensure that the turret seismic restraints cannot be disengaged and that power is not supplied to the turret rotate motor unless the MCO is fully raised in the MHM. Shear of an MCO by the MHM may be possible during a seismic event if the MCO is partially inserted in a storage tube, a pit, or the transport cask. Lateral movement of the massive MHM during a design basis earthquake could shear the MCO. Seismic restraints on the MHM trolley and gantry will prevent significant lateral movement when the restraints are applied. The MHM could also apply significant lateral forces against an MCO if the bridge or trolley drives were activated by operator error or MHM malfunction while the MCO is partially lowered from the MHM. MHM interlock $P 21$ prevents the raising or lowering of the MCO hoist unless the bridge and trolley seismic restraints are applied. MFM interlocks (P3, P6, P8, P26, P80) prevent the disengagement of the bridge and turret seismic restraints and internupts bridge and trolley drive motor power unless the MCO is fully raised.

Shear of the MCO could also be possible if the MHM were to enter the service area while the $\mathrm{MCO}$ is being lowered into the service pit by the receiving crane (SA-F-05). The MHM could collide with the crane or also directly with the partially lowered $\mathrm{MCO}$, causing the $\mathrm{MCO}$ to be sheared. A MHM interlock (P5) inhibits the MHM from entering the service area "overlap zone" if the receiving crane is located in this area. Because the failure of the receiving crane sensor and striker deployment system that activates the MHM limit switches associated with interlock P5 is not incredible, analysis has been performed to assess the damage to the MCO in this accident scenario. Analysis demonstrates that such an accident would not cause unacceptable damage to the MCO (Petersen 1998). The transportation cask will adequately protect the MCO so that it is not breached and no criticality geometry control contingencies are violated.

No consequence analyses are performed for MCO shears caused by the MFM because the controls to prevent such an event are robust and sufficient to consider this accident incredible.

\subsubsection{Cask-Multi-Canister Overpack Shear by the Receiving Crane}

If the receiving crane were to be moved (translated) while the cask-MCO were partially lowered into the service pit, a shear force would be applied to the outer transportation cask. The lateral forces exerted upon the cask in this scenario are expected to be bounded by those experiences by the cask during a collision with the MHM (Petersen 1998). Because of the substantial design of the cask, engineering judgement leads one to conclude that such an event would not damage the $\mathrm{MCO}$ within the cask. Only superficial damage to the outer cask is considered to be likely. No consequence analyses are performed for any MCO shears caused by 


\section{SNF-3328 REV 0}

the receiving crane because the cask is expected to be able to fully protect the MCO from damage.

\subsection{SOURCE TERM ANALYSIS}

Those accidents that could breach the $\mathrm{MCO}$ require safety-class mitigation to prevent violation of criticality contingencies. Because the development of radiological source term and dose consequences could not lead to more restrictive safety classification and controls, no source term is developed.

\subsection{CONSEQUENCE ANALYSIS}

A consequence analysis was not performed for $\mathrm{MCO}$ shears caused by the MHM because the controls to prevent such an event are robust and sufficient to make this accident not credible. Any drop, impact, or shear accidents that were deemed to have the potential to violate the MCO criticality geometry control safety functions have been assigned preventive features that make their occurrence beyond extremely unlikely.

\subsection{COMPARISON TO GUIDELINES}

The consequences of a cask-MCO drop by the receiving crane into the maintenance pit with a slap-down have not been determined. Based upon the results from a similar analysis (HNF-SD-SNF-DP-007), it is expected that such an accident would damage the MCO center tube geometry sufficiently to cause a criticality specification violation. While definitive supporting calculations do not exist, no radiological releases or associated onsite $(100 \mathrm{~m})$ or offsite dose consequences are expected from such an accident because of the structural protection provided by the cask. The receiving crane will be instrumented with an absolute resolver (to measure and report current crane location) and an interlock scheme that will only allow the crane to travel west of the FFTF pit without requiring a key-operated override switch to be used to allow power to the crane drive. Because this accident could lead to the violation of a criticality control limit, this receiving crane interlock and associated electronics will need to be classified safety class.

No dose consequences are expected from a drop of the transportation cask lid onto the MCO. Dose consequences could result only if the MCO rupture disk were damaged or failed. Because MCO internal pressures above the rupture disk actuation pressure $\left(150 \mathrm{lb} / \mathrm{in}^{2}\right.$ gauge) are not credible at the CSB (HNF-SD-SNF-TI-015), a blow-down of the MCO and associated radiological release are not possible.

The drop of the MCO by the MHM could have safety-class consequences because of the potential to violate criticality control limits. No dose consequence estimates are needed to determine structure, system, and component (SSC) or TSR classification. Impact absorbers that 
mitigate drop consequences must be safety class. This drop has been recently determined to be incredible (SNF-4087).

The shear of the MCO by the MHM could have safety-class consequences because of the potential to violate criticality geometry control limits. No dose consequence estimates are needed to determine SSC or TSR classification. Mechanical equipment and MHM control system interlocks, sensors, relays, and power contactors that prevent a shear must be safety class.

The drop of the cask-MCO by the receiving crane from heights greater than 40 in. could have safety-class consequences because of the potential to violate criticality geometry control limits. No dose consequence estimates are needed to determine SSC or TSR classification. Equipment used to prevent a drop into the maintenance pit or from heights greater than 40 in. onto the receiving area floor must be safety class. Recently, safety-class cask transfer system has been implemented to prevent these drops.

\title{
2.6 SUMMARY OF SAFETY-CLASS STRUCTURES, SYSTEMS, AND COMPONENTS AND TECHNICAL SAFETY REQUIREMENT CONTROLS
}

The SSCs and TSR controls designated to prevent the loss of criticality control and the dose consequences of the rearrangement of MCO internals caused by a shear accident are as follows:

\subsubsection{Possible Rearrangement of Multi-Canister Overpack Internals Because of Shear}

\author{
Prevent Lateral MHM Movement
}

- Safety-class SSCs

- MHM interlock (P21) and sensors - Ensure that the MCO hoist cannot operate unless the bridge seismic clamps and trolley seismic restraints are applied when an MCO is in the MHM; the interlock circuitry includes relays, contactors, and sensors (limit switches)

- MHM interlocks (P3, P6, P8, P26, P80), sensors, and switches - Prevent the seismic restraints from disengaging and power being applied to the bridge and trolley drive motors unless the MCO hoist is fully raised when an MCO is in the MFM; the interlock circuitry includes contactors and relays, and sensors (resolvers, limit switches, photoelectric switches)

- MHM seismic restraints, rails, and rail frogs - Prevent translational movement of the MHM whenever engaged when an MCO is in the MHM (restraints must be engaged prior to $\mathrm{MCO}$ hoist operation) 
- Seismic detection and MHM power-disconnect system - Detects seismic event (magnitude $0.25 \mathrm{~g}$ horizontal $[0.74 \mathrm{~g} / 3]$ and $0.16 \mathrm{~g}$ vertical $[0.49 \mathrm{~g} / 3]$ ) and removes all power to the MHM; removal of power to prevent operation of the MCO hoist, disengagement of seismic restraints, and MHM translational movement (MHM interlocks are not seismically qualified)

- MHM rails and rail frogs - Prevent inadvertent movement and/or structural failure of the MHM, with collateral damage to safety-class structures or an $\mathrm{MCO}$

- Safety-significant SSCs

- MHM and MHM MCO hoist - Required by DOE Order 6430.1A and U.S. Nuclear Regulatory Commission (NRC) equivalency important-to-safety Category B for SSCs that handle SNF

- TSR

- Operability of MHM interlocks (P3, P6, P8, P21, P26, P80) and seismic detection and MHM power-disconnect system; the interlock circuitry includes relays, contactors, and sensors (resolvers, limit switches, photoelectric switches).

\section{Prevent Rotational MHM Turret Movement}

- Safety-class SSCs

- MHM interlock (P9) and sensors - Ensure that the MCO hoist cannot operate unless the turret seismic restraints are applied when an MCO is in the MHM; the interlock circuitry includes power contactors, relays, and proximity sensors

- MHM interlocks (P6, P80) and sensors - Prevent the seismic restraints from disengaging and power being applied to the turret rotational drive motors unless the MCO hoist is fully raised when an MCO is in the MHM; the interlock circuitry includes power contactors, relays, and sensors (resolver, limit switch, photoelectric switch)

- MHM seismic restraints - Prevent rotational movement of the MHM whenever engaged when an MCO is in the MHM (restraints must be engaged prior to MCO hoist operation)

- Seismic detection and MHM power-disconnect system - Detects seismic event (magnitude $0.25 \mathrm{~g}$ horizontal $[0.74 / 3 \mathrm{~g}]$ and $0.16 \mathrm{~g}$ vertical $[0.49 / 3 \mathrm{~g}]$ ) and removes all power to the MHM; removal of power to prevent operation of the MCO hoist, disengagement of seismic restraints, and MHM rotational movement (MHM interlocks are not seismically qualified) 
- Safety-significant SSCs

- MHM and MHM MCO hoist - Required by DOE Order 6430.1A and NRC equivalency important-to-safety Category $B$ for SSCs that handle SNF

- TSR

- Operability of MHM interlocks (P6, P9, P80) and seismic detection and MHM power-disconnect system; the interlock circuitry includes power contactors, relays, and sensors (resolvers, limit switches, photoelectric switches, proximity sensors).

The SSCs and TSR controls designated to prevent the loss of criticality control and the dose consequences of the rearrangement of MCO internals caused by a shear accident are summarized in Table 2-2. In accordance with Title 10, Code of Federal Regulations, Part 72, "Licensing Requirements for the Independent Storage of Spent Nuclear Fuel and High-Level Radioactive Waste," Section 72.3, "Definitions" (10 CFR 72.3), SSCs also have been identified that are considered important to safety. This important-to-safety classification is further delineated using a graded approach provided by NUREG/CR-6407, Classification of Transportation Packaging and Dry Spent Fuel Storage System Components According to Importance to Safety. NRC important-to-safety designations are identified in Table 2-2 for the rearrangement of MCO internals accidents. Defense-in-depth features also are included for each specific accident in Table 2-2.

The suite of safety SSCs and TSR controls necessary and sufficient to prevent the two design basis $\mathrm{MCO}$ shear accidents do not address some of the other accidents in the rearrangement of MCO internals accident category. Table 2-2 also lists the safety SSCs and TSR controls needed to prevent or control these accidents. Because these accidents are substantially different in development and progression from the DBAs, each scenario and the corresponding controls are also described below.

\subsubsection{Possible Rearrangement of Multi-Canister Overpack Internals Because of Drops}

Several drop accidents were evaluated and are listed here along with specific safety SSCs and TSR controls to prevent the described drop accident. The drop of the cask-MCO from the receiving crane onto the load-in/load-out area floor or into the MCO service station pit could lead to the loss of criticality geometry control of the fuel in the MCO. Analysis has demonstrated that the cask-MCO structural and criticality control features are sufficient to remain intact if the cask-MCO is dropped onto the concrete from a height less than 40 in. The SSCs and TSR controls selected either prevent the cask-MCO from being hoisted more than $40 \mathrm{in}$. above the 
Table 2-2. Summary of Safety Features Required to Prevent Rearrangement of Multi-Canister Overpack Internals. ( 9 sheets)

\begin{tabular}{|c|c|c|c|c|}
\hline Accident & $\begin{array}{l}\text { Checklist } \\
\text { designator }\end{array}$ & $\begin{array}{l}\text { General } \\
\text { function }\end{array}$ & Safety feature and safety classification ${ }^{b}$ & $\begin{array}{l}\text { NRC ITS } \\
\text { category }^{b}\end{array}$ \\
\hline \multicolumn{5}{|c|}{ Possible rearrangement of MCO internals because of a drop or shear } \\
\hline $\begin{array}{l}\text { MCO or cask } \\
\text { shear by the } \\
\text { MHM from } \\
\text { lateral MHM } \\
\text { movement }\end{array}$ & $\begin{array}{l}\text { SA-F-07b } \\
\text { OA-F-07 } \\
\text { WS-F-07 } \\
\text { OU-R-01 }\end{array}$ & $\begin{array}{l}\text { Prevent MCO } \\
\text { translational } \\
\text { shear }\end{array}$ & $\begin{array}{l}\text { Safety-class SSCs: } \\
\text { - MHM interlock (P21), sensors, and switches } \\
\text { and switches } \\
\text { - MHM seismic restraints, rails, and rail frogs } \\
\text { - Seismic detection and MHM power-disconnect } \\
\text { system } \\
\text { - MUHM rails and rail frogs } \\
\text { Safety-significant SSCs: } \\
\text { MIMM and MrMM MCO hoist } \\
\text { TSR: } \\
\text { Operability of MHM interlocks (P3, P6, P8, P21, } \\
\text { P26, P8O), seismic detection and MHM power- } \\
\text { disconnect system; MHM interlock } \\
\text { Defense in depth: } \\
\text { - Personnel are trained in sitewide and facility- } \\
\text { specific emergency response procedures that } \\
\text { include steps to place the facility in the safest } \\
\text { possible condition. } \\
\text { The MHM provides active, filtered ventilation at its } \\
\text { open interface with both the service station and the } \\
\text { sampling/weld station. } \\
\text { The MHM is designed to ASME NOG-1" to } \\
\text { preclude tipping. } \\
\text { The MHM has an auditory indication of its } \\
\text { movement (i.e., alarms). } \\
\text { The MHM is limited to relatively slow movement. } \\
\text { The MHM is provided with a backup grapple } \\
\text { disengagement capability. } \\
\text { Personnel are trained to procedures detailing the } \\
\text { safe sequence of operations; these procedures } \\
\text { prohibit interferences between the receiving crane } \\
\text { and the MHM }\end{array}$ & $\begin{array}{l}\text { A } \\
\text { A } \\
\text { A } \\
\text { A } \\
\text { A }\end{array}$ \\
\hline
\end{tabular}


Table 2-2. Summary of Safety Features Required to Prevent Rearrangement of Multi-Canister Overpack Internals. ( 9 sheets)

\begin{tabular}{|c|c|c|c|c|}
\hline Accident & $\begin{array}{l}\text { Checklist } \\
\text { designator }\end{array}$ & $\begin{array}{l}\text { General } \\
\text { function }\end{array}$ & Safety feature and safety classification ${ }^{b}$ & $\begin{array}{l}\text { NRC ITS } \\
\text { category" }\end{array}$ \\
\hline $\begin{array}{l}\text { MCO or MCO } \\
\text { hoist cable } \\
\text { shear by } \\
\text { rotation of the } \\
\text { MHM turret }\end{array}$ & $\begin{array}{l}\text { SA-E-07 } \\
\text { OA-E-07 } \\
\text { WS-E-07 } \\
\text { OU-R-01 }\end{array}$ & $\begin{array}{l}\text { Prevent MCO } \\
\text { rotational } \\
\text { shear }\end{array}$ & $\begin{array}{l}\text { Safety-class SSCs: } \\
\text { - MHM interlock (P9), sensors, and switches } \\
\text { - MHM interlocks (P6, P80), sensors, and switches } \\
\text { - Seism seismic retectraints } \\
\text { system } \\
\text { Safety-significant SSCS: } \\
\text { MHM and MHM MCO hoist } \\
\text { TSR: } \\
\text { - Operability of MHM interlocks (P6, P9, P80) and } \\
\text { seismic detection and MHM power-disconnect } \\
\text { system, and interlock circuitry } \\
\text { Defense in depth: } \\
\text { - Personnel are trained in sitewide and facility- } \\
\text { specific emergency response procedures that } \\
\text { include steps to place the facility in the safest } \\
\text { possible condition } \\
\text { The MHM provides active, filtered ventilation at its } \\
\text { open interface with both the service station and the } \\
\text { sampling/weld station } \\
\text { The MHM is designed to ASME NOG-1 }{ }^{\circ} \text { to } \\
\text { preclude tipping } \\
\text { - The MHM has an auditory indication of its } \\
\text { movement (i.e., alarms) } \\
\text { - The MHM is limited to relatively slow movement } \\
\text { - The MHM is provided with a backup grapple } \\
\text { disengagement capability } \\
\text { - Personnel are trained to procedures detailing the } \\
\text { safe sequence of operations; these procedures } \\
\text { prohibit interferences between the receiving crane } \\
\text { and the MHM }\end{array}$ & $\begin{array}{l}\text { A } \\
\text { A } \\
\text { A } \\
\text { A }\end{array}$ \\
\hline
\end{tabular}


SNF-3328 REV 0

Table 2-2. Summary of Safety Features Required to Prevent Rearrangement of Multi-Canister Overpack Internals. (9 sheets)

\begin{tabular}{|c|c|c|c|c|}
\hline Accident & $\begin{array}{l}\text { Checklist } \\
\text { designator }\end{array}$ & $\begin{array}{l}\text { General } \\
\text { function }\end{array}$ & Safety feature and safety classification ${ }^{b}$ & $\begin{array}{l}\text { NRC ITS } \\
\text { category }^{b}\end{array}$ \\
\hline $\begin{array}{l}\text { Cask-MCO } \\
\text { drop from the } \\
\text { receiving } \\
\text { crane }^{d}\end{array}$ & $\begin{array}{l}\text { TV-G-13 } \\
\text { SA-G-03a } \\
\text { SA-G-13 }\end{array}$ & $\begin{array}{l}\text { Prevent the } \\
\text { MCO from } \\
\text { sustaining } \\
\text { damage } \\
\text { exceeding the } \\
\text { allowable } \\
\text { level }\end{array}$ & $\begin{array}{l}\text { Safety-class SSCs: } \\
\text { Transportation cask } \\
\text { MCO shell, locking ring, and shield plug } \\
\text { - MCO fuel baskets including criticality center post } \\
\text { Receiving crane lifting yoke (length) } \\
\text { MCO service station impact absorber } \\
\text { Sask transfer safety system } \\
\text { Safety-significant SSCs: } \\
\text { Teceiving crane and hoist } \\
\text { TSRs: } \\
\text { - Use of proper yoke (length) to lift the cask-MCO } \\
\text { Impact absorber is installed in the MCO service } \\
\text { station pit and is functional } \\
\text { Defense in depth: } \\
\text { - The operators of the receiving crane are trained and } \\
\text { qualified to perform their duties safely, which } \\
\text { includes following procedures for safe handling of } \\
\text { the transportation cask } \\
\text { - Regular maintenance is performed on the } \\
\text { transporter to ensure it is in good working order } \\
\text { Qualified crane operators } \\
\text { Maintenance and operations manuals and details } \\
\text { are provided by crane vendors } \\
\text { The hoist design includes } \\
\text { - Interlocks to preclude lift and horizontal motion at } \\
\text { same time } \\
\text { - Dual brakes } \\
\text { - No free fall capacity }\end{array}$ & $\begin{array}{c}\text { A } \\
\text { A } \\
\text { A } \\
\text { A } \\
\text { NA } \\
\text { A } \\
\\
\text { B }\end{array}$ \\
\hline
\end{tabular}


Table 2-2. Summary of Safety Features Required to Prevent Rearrangement of Multi-Canister Overpack Internals. (9 sheets)

\begin{tabular}{|c|c|c|c|c|}
\hline Accident & $\begin{array}{l}\text { Checklist } \\
\text { designator" }\end{array}$ & $\begin{array}{r}\text { General } \\
\text { function }\end{array}$ & Safety feature and safety classification ${ }^{b}$ & $\begin{array}{l}\text { NRC ITS } \\
\text { category }^{b}\end{array}$ \\
\hline $\begin{array}{l}\text { Drop of MCO } \\
\text { back into the } \\
\text { cask or onto } \\
\text { the cask rim by } \\
\text { the MHM }\end{array}$ & $\begin{array}{l}\text { SA-G-03a } \\
\text { SA-G-13 }\end{array}$ & $\begin{array}{l}\text { Prevent the } \\
\text { MCO from } \\
\text { sustaining } \\
\text { damage } \\
\text { exceeding the } \\
\text { allowable } \\
\text { level }\end{array}$ & $\begin{array}{l}\text { Safety-class SSCs: } \\
\text { - MCO shell, locking ring, and shield plug } \\
\text { SCO fuel and scrap baskets including center post } \\
\text { Safety-significant SSCS: } \\
\text { - MHM and MHMMCO hoist } \\
\text { Defense in depth: } \\
\text { - The MHM grapple is designed with a mechanical } \\
\text { lock such that it should not be able to open while a } \\
\text { load is suspended from it } \\
\text { - Lifting devices used at the CSB are designed to } \\
\text { handle the loads they will carry } \\
\text { - Personnel are trained to facility-specific procedures } \\
\text { in the proper handling of the transportation cask, } \\
\text { MCO, receiving crane, gantry, and MHM } \\
\text { - Regular maintenance is performed to ensure it is in } \\
\text { good working order } \\
\text { - Qualified operators } \\
\text { Maintenance and operations manuals and details } \\
\text { are provided }\end{array}$ & $\begin{array}{l}\text { A } \\
\text { A } \\
\text { B }\end{array}$ \\
\hline $\begin{array}{l}\text { Drop of the } \\
\text { MCO from the } \\
\text { MHM into the } \\
\text { maintenance } \\
\text { pit }^{\mathrm{f}}\end{array}$ & $\begin{array}{l}\text { SA-G-03a } \\
\text { SA-G-13 }\end{array}$ & $\begin{array}{l}\text { Prevent the } \\
\text { MCO from } \\
\text { sustaining } \\
\text { damage } \\
\text { exceeding the } \\
\text { allowable } \\
\text { level }\end{array}$ & $\begin{array}{l}\text { Safety-class SSCs: } \\
\text { - MHM interlocks (P3, P8), sensors } \\
\text { MHM interlocks (P26, P80, P85), sensors } \\
\text { Safety-significant SSCS: } \\
\text { - MHM and MHM MCO hoist } \\
\text { TSR: } \\
\text { - Operability of interlocks (P3, P8, P26, P80, P85) } \\
\text { Defense in depth: } \\
\text { - The MHM grapple is designed with a mechanical } \\
\text { lock such that it should not be able to open while a } \\
\text { load is suspended from it } \\
\text { - Lifting devices used at the CSB are designed to } \\
\text { handle the loads they will carry } \\
\text { - Personnel are trained to facility-specific procedures } \\
\text { in the proper handling of the transportation cask, } \\
\text { MCO, receiving crane, gantry, and MHM } \\
\text { - Regular maintenance is performed to ensure it is in } \\
\text { good working order } \\
\text { - Qualified operators } \\
\text { - Maintenance and operations manuals and details } \\
\text { are provided }\end{array}$ & $\begin{array}{l}\mathrm{A} \\
\mathrm{A}\end{array}$ \\
\hline
\end{tabular}


SNF-3328 REV 0

Table 2-2. Summary of Safety Features Required to Prevent Rearrangement of

Multi-Canister Overpack Internals. (9 sheets)

\begin{tabular}{|c|c|c|c|c|}
\hline Accident & $\begin{array}{l}\text { Checklist } \\
\text { designator }\end{array}$ & $\begin{array}{l}\text { General } \\
\text { function }\end{array}$ & Safety feature and safety classification ${ }^{b}$ & $\begin{array}{l}\text { NRC ITS } \\
\text { category" }\end{array}$ \\
\hline $\begin{array}{l}\text { Drop of the } \\
\text { cask-MCO } \\
\text { from the } \\
\text { receiving crane } \\
\text { into the FFTF } \\
\text { or MHM } \\
\text { maintenance } \\
\text { pit }\end{array}$ & $\begin{array}{l}\text { SA-G-03b } \\
\text { SA-G-13 }\end{array}$ & $\begin{array}{l}\text { Prevent the } \\
\text { MCO from } \\
\text { sustaining } \\
\text { damage } \\
\text { exceeding the } \\
\text { allowable } \\
\text { level }\end{array}$ & $\begin{array}{l}\text { Safety-class SSCs: } \\
\text { Receiving crane positioning/interlock control } \\
\text { system } \\
\text { TSRs: } \\
\text { - Administrative use of the supervisor-controlled } \\
\text { fortress key for movement of receiving crane over or } \\
\text { east of the FFTF pit when there is no cask-MCO } \\
\text { load } \\
\text { - Operability of receiving crane positioning/interlock } \\
\text { control system } \\
\text { Defense in depth: } \\
\text { The MHM grapple is designed with a mechanical } \\
\text { lock such that it should not be able to open while a } \\
\text { load is suspended from it } \\
\text { - Liting devices used at the CSB are designed to } \\
\text { handle the loads they will carry } \\
\text { - Personnel are trained to facility-specific procedures } \\
\text { in the proper handling of the transportation cask, } \\
\text { MCO, receiving crane, gantry, and MHM } \\
\text { - Regular maintenance is performed to ensure it is in } \\
\text { good working order } \\
\text { Qualified operators } \\
\text { - Maintenance and operations manuals and details } \\
\text { are provided }\end{array}$ & A \\
\hline
\end{tabular}


Table 2-2. Summary of Safety Features Required to Prevent Rearrangement of

Multi-Canister Overpack Internals. (9 sheets)

\begin{tabular}{|c|c|c|c|c|}
\hline Accident & $\begin{array}{l}\text { Checklist } \\
\text { designator }\end{array}$ & $\begin{array}{l}\text { General } \\
\text { function }\end{array}$ & Safety feature and safety classification ${ }^{b}$ & $\begin{array}{l}\text { NRC ITS } \\
\text { category }^{b}\end{array}$ \\
\hline $\begin{array}{l}\text { CSB facility } \\
\text { structure falls } \\
\text { onto an MCO } \\
\text { or } \\
\text { MHM falls } \\
\text { onto the } \\
\text { operating deck }\end{array}$ & OU-R-01 & $\begin{array}{l}\text { Prevent } \\
\text { collapse of } \\
\text { CSB } \\
\text { structures or } \\
\text { loss of } \\
\text { structural } \\
\text { integrity of } \\
\text { the facility } \\
\text { when there is } \\
\text { SNF in the } \\
\text { facility } \\
\text { during NPH } \\
\text { events }\end{array}$ & $\begin{array}{l}\text { Safety-class SSCS: } \\
\text { - Standard and overpack storage tubes, carbon steel } \\
\text { base slab embeds, tube base assemblies, operating } \\
\text { deck, and vault } \\
\text { Safety-significant SSCs: } \\
\text { - Operating area shelter (waiver } 1 \text { to HNF-PRO-704) } \\
\text { Rail frogs, rails, MHM seismic restraints, MHM } \\
\text { (structural) (waiver } 2 \text { to HNF-PRO-704) } \\
\text { TSR: } \\
\text { - Double verification that rail frogs are installed and } \\
\text { secure } \\
\text { Defense in depth: } \\
\text { - Personnel are trained in sitewide and facility- } \\
\text { specific emergency response procedures that } \\
\text { include steps to place the facility in the safest } \\
\text { possible condition } \\
\text { The facility provides shelter for workers } \\
\text { - CSB personnel are trained in sitewide and facility- } \\
\text { specific emergency response procedures that } \\
\text { include steps to place the facility in the safest } \\
\text { possible condition }\end{array}$ & $\begin{array}{l}B \\
B\end{array}$ \\
\hline $\begin{array}{l}\text { Water line } \\
\text { break leads to } \\
\text { loss of } \\
\text { structural } \\
\text { integrity of the } \\
\text { CSB facility }\end{array}$ & OU-P-05 & $\begin{array}{l}\text { Detect water } \\
\text { leak to } \\
\text { prevent } \\
\text { washout of } \\
\text { compacted } \\
\text { soil near the } \\
\text { CSB to } \\
\text { protect } \\
\text { building } \\
\text { seismic } \\
\text { analysis } \\
\text { assumptions }\end{array}$ & $\begin{array}{l}\text { Safety-class SSCS: } \\
\text { - None } \\
\text { TSRs: } \\
\text { - Periodic walkdowns of the facility to ensure that the } \\
\text { SSI assumptions are protected } \\
\text { - Walkdowns of the facility after operating basis } \\
\text { earthquakes } \\
\text { Defense in depth: } \\
\text { - None }\end{array}$ & None \\
\hline
\end{tabular}


SNF-3328 REV 0

Table 2-2. Summary of Safety Features Required to Prevent Rearrangement of Multi-Canister Overpack Internals. (9 sheets)

\begin{tabular}{|c|c|c|c|c|}
\hline Accident & $\begin{array}{l}\text { Checklist } \\
\text { designator }\end{array}$ & $\begin{array}{l}\text { General } \\
\text { function }\end{array}$ & Safety feature and safety classification ${ }^{b}$ & $\begin{array}{l}\text { NRC ITS } \\
\text { category }\end{array}$ \\
\hline $\begin{array}{l}\text { MCO drop } \\
\text { into or onto the } \\
\text { storage tube }\end{array}$ & $\begin{array}{l}\text { OA-G-03 } \\
\text { OA-G-13 }\end{array}$ & $\begin{array}{l}\text { Limit impact } \\
\text { forces on the } \\
\text { MCO, tube, } \\
\text { and } \\
\text { associated } \\
\text { structures to } \\
\text { acceptable } \\
\text { levels }\end{array}$ & $\begin{array}{l}\text { Safety-class SSCS: } \\
\text { - Storage tube bottom impact absorber } \\
\text { Safety-significant SSCs: } \\
\text { - Storage tube intermediate impact absorber } \\
\text { TSRs: } \\
\text { - Bottom impact absorber is installed in each storage } \\
\text { tube prior to placing an MCO in the storage tube } \\
\text { - Intermediate impact absorber is installed in each } \\
\text { storage tube prior to placement of a second MCO in } \\
\text { that storage tube } \\
\text { - Interface guide ring is in place before arrival of the } \\
\text { MCO in the MHM over a storage tube } \\
\text { Defense in depth: } \\
\text { - The MHM grapple is designed with a mechanical } \\
\text { lock such that it should not be able to open while a } \\
\text { load is suspended from it } \\
\text { - Lifting devices used at the CSB are designed to } \\
\text { handle the loads they will carry } \\
\text { - Personnel are trained to facility-specific procedures } \\
\text { in the proper handling of the MCO and MHM } \\
\text { - Qualified crane operators } \\
\text { Maintenance and operations manuals and details } \\
\text { are provided by crane vendors } \\
\text { - The hoist design includes } \\
\text { - Interlocks to preclude lift and horizontal motion at } \\
\text { same time } \\
\text { - Dual brakes } \\
\text { - No free fall capacity }\end{array}$ & $\begin{array}{c}\text { A } \\
\text { NA } \\
\text { B }\end{array}$ \\
\hline
\end{tabular}


Table 2-2. Summary of Safety Features Required to Prevent Rearrangement of Multi-Canister Overpack Internals. (9 sheets)

\begin{tabular}{|c|c|c|c|c|}
\hline Accident & $\begin{array}{l}\text { Checklist } \\
\text { designator }\end{array}$ & $\begin{array}{l}\text { General } \\
\text { function }\end{array}$ & Safety feature and safety classification ${ }^{b}$ & $\begin{array}{l}\text { NRC ITS } \\
\text { category }^{b}\end{array}$ \\
\hline $\begin{array}{l}\text { MCO drop } \\
\text { into the } \\
\text { sampling/weld } \\
\text { station pit }\end{array}$ & $\begin{array}{l}\text { WS-G-03a } \\
\text { WS-G-13 }\end{array}$ & $\begin{array}{l}\text { Limit impact } \\
\text { forces on the } \\
\text { MCO to } \\
\text { acceptable } \\
\text { levels }\end{array}$ & $\begin{array}{l}\text { Safetty-class SSCs: } \\
\text { - Sampling/weld station impact absorber } \\
\text { TSR: } \\
\text { - Sampling/weld station impact absorber is installed } \\
\text { in the pit prior to placing an MCO in the } \\
\text { sampling/weld station } \\
\text { Defense in depth: } \\
\text { - The MHM grapple is designed with a mechanical } \\
\text { lock such that it should not be able to open while a } \\
\text { load is suspended from it } \\
\text { - Lifting devices used at the CSB are designed to } \\
\text { handle the loads they will caryy } \\
\text { - Personnel are trained to facility-specific procedures } \\
\text { in the proper handling of the transportation cask, } \\
\text { MCO, receiving crane, and MHM } \\
\text { - Qualified crane operators } \\
\text { - Maintenance and operations manuals and details } \\
\text { are provided by crane vendors } \\
\text { - The hoist design includes } \\
\text { - Interlocks to preclude lift and horizontal motion at } \\
\text { same time } \\
\text { - Dual brakes } \\
\text { - No free fall capacity }\end{array}$ & A \\
\hline \multicolumn{5}{|c|}{ Possible rearrangement of MCO internals due to collision } \\
\hline $\begin{array}{l}\text { MHM collides } \\
\text { with } \\
\text { cask-MCO as } \\
\text { it is being } \\
\text { lowered into } \\
\text { MCO service } \\
\text { station pit by } \\
\text { the receiving } \\
\text { crane }\end{array}$ & SA-F-05 & & $\begin{array}{l}\text { Safety-class SSCS: } \\
\text { - Transportation cask } \\
\text { Defense in depth: } \\
\text { - Personnel are trained to procedures detailing the } \\
\text { safe sequence of operations; these procedures } \\
\text { prohibit interferences between the receiving crane } \\
\text { and the MHM. } \\
\text { - The frogs on the receiving crane's tracks have stops } \\
\text { - The receiving crane has an auditory indication of its } \\
\text { movement (i.e., alarms) } \\
\text { - The receiving crane is limited to relatively slow } \\
\text { movement } \\
\text { The receiving crane design includes such features } \\
\text { as restricted speed, load float, micropositioner, and } \\
\text { auditory movement alarms } \\
\text { - Regular maintenance is performed on the receiving } \\
\text { crane to ensure it is in good working order }\end{array}$ & A \\
\hline
\end{tabular}


Table 2-2. Summary of Safety Features Required to Prevent Rearrangement of Multi-Canister Overpack Internals. (9 sheets)

\begin{tabular}{|c|c|c|c|c|}
\hline Accident & $\begin{array}{l}\text { Checklist } \\
\text { designator }\end{array}$ & $\begin{array}{l}\text { General } \\
\text { function }\end{array}$ & Safety feature and safety classification ${ }^{b}$ & $\begin{array}{l}\text { NRC ITS } \\
\text { category }^{\circ}\end{array}$ \\
\hline \multicolumn{5}{|c|}{ Possible rearrangement of $\mathrm{MCO}$ internals due to impact from gas cylinder } \\
\hline $\begin{array}{l}\text { Compressed } \\
\text { gas cylinder } \\
\text { missiles }\end{array}$ & $\begin{array}{l}\text { TV-F-06 } \\
\text { SA-F-06 } \\
\text { WS-F-06 }\end{array}$ & $\begin{array}{l}\text { Prevent } \\
\text { compressed } \\
\text { gas cylinders } \\
\text { from } \\
\text { becoming a } \\
\text { missile } \\
\text { hazard }\end{array}$ & $\begin{array}{l}\text { Programmatic control: } \\
\text { A TSR is not required but a Site maintenance } \\
\text { program on compressed gas cylinders is performed } \\
\text { on gas cylinders by the suppliers } \\
\text { Defense in depth: } \\
\text { - Operators are trained in the proper handling of } \\
\text { compressed gas cylinders according to established } \\
\text { procedures. } \\
\text { - Gas cylinders that supply the inert gas system are } \\
\text { located outside of the CSB }\end{array}$ & \\
\hline
\end{tabular}

'Checklist designators are from HNF-SD-SNF-HIE-001, 1999, Canister Storage Building Hazard Analysis Report, Rev. 1, Fluor Daniel Hanford, Incorporated, Richland, Washington.

'Safety classification for DBA in this category. Safety classification or ITS category could be different for another DBA category.

'ASME NOG-1, 1995, Rules for Construction of Overhead and Gantry Cranes (Top Rumning Bridge, Multiple Girder), American Society of Mechanical Engineers, New York, New York.

${ }^{d}$ Impact absorber specification requires that the deceleration of a maximum-weight MCO dropped from the maximum height ( $40 \mathrm{in}$. above the floor to the top of the impact absorber) is less than $35 \mathrm{~g}$.

${ }^{\circ}$ Compressed gas cylinder becomes a missile and impacts the $\mathrm{MCO}$ or cask-MCO because the operator removes the flow-restricting orifice.

'This scenario was recently determined to be incredible per SNF-4087, The Frequency of a Multi-Canister Overpack (MCO) Drop by the Multi-Canister Overpack Handling Machine (MHM).

$\mathrm{CSB}=$ Canister Storage Building.

DBA = design basis accident.

FFTF $=$ Fast Flux Test Facility .

ITS $=$ important to safety.

$\mathrm{MCO}=$ multi-canister overpack.

MHM = multi-canister overpack handling machine.

NA = not applicable to ITS category classification.

$\mathrm{NPH}=$ natural phenomena hazard.

$\mathrm{NRC}=$ U.S. Nuclear Regulatory Commission.

$\mathrm{SNF}=$ spent nuclear fuel.

SSC = structure, system, and component.

SSI $=$ soil-structure interaction.

$\mathrm{TSR}=$ technical safety requirement. 
underlying concrete or provide for impact absorption to reduce the forces on the MCO in case of a drop. The following are the specific safety SSCs and TSR controls that prevent this event:

- Safety-class SSCs

- $\quad$ MCO transportation cask $\rightarrow$ Provides structural protection to the MCO when the MCO is inside the cask from drops from the receiving crane

- MCO shell, locking ring, and shield plug - Provide structural protection, criticality geometry control (73.04 in. circumference), and containment of SNF should the cask-MCO drop from the receiving crane

- MCO fuel and scrap baskets including center post - Provide criticality geometry control of the SNF (maximum 2-in. deflection from MCO centerline)should the MCO drop from the receiving crane

- Receiving crane lifting yoke (length) - Limit lift height above the floor (maximum of $40 \mathrm{in}$.) when the cask-MCO is being lifted by the receiving crane

- MCO service station pit impact absorber - Limits deceleration forces to less than $35 \mathrm{~g}$ for a maximum-weight $\mathrm{MCO}$ if the cask-MCO is dropped from receiving crane into the $\mathrm{MCO}$ service station pit

- Safety-significant SSCs

- Receiving crane and hoist - Required by DOE Order 6430.1A and NRC equivalency important-to-safety Category $B$ for SSCs that handle SNF

- TSRs

- Use of proper yoke (length) to lift the cask-MCO

- Impact absorber is installed in the MCO service station pit and is functional.

The drop of the MCO from the MHM back into or onto the rim of the transportation cask has been analyzed for damage to the $\mathrm{MCO}$. Calculations have been completed that demonstrate that the $\mathrm{MCO}$ will not sustain unacceptable damage from this drop accident from the maximum height possible from the MHM MCO hoist and that this drop is incredible. An MCO that drops back into the cask will not be damaged in such a way that it cannot be retrieved from the cask using the MHM (HNF-SD-SNF-DP-007, HNF-SD-SNF-SARR-005). The following are the specific safety SSCs that prevent this event: 


\section{- Safety-class SSCs}

- MCO shell, locking ring, and shield plug - Provide structural protection, criticality geometry control (73 in. circumference), and containment of SNF should the MCO drop from the MHM at the MCO service station pit

- MCO fuel and scrap baskets including center post - Provides criticality geometry control of SNF (maximum 2-in. deflection from MCO centerline)should the MCO drop from the MHM at the MCO service station pit

- Safety-significant SSCs

- MHM and MHM MCO hoist - Required by DOE Order 6430.1A and NRC equivalency important-to-safety Category B for SSCs that handle SNF.

No TSR controls are needed for this accident.

The drop of the MCO from the MHM into the MHM maintenance pit could lead to the loss of criticality geometry control of the fuel in the MCO. This has been recently determined to be incredible. The following are the specific safety SSCs and TSR controls that prevent this event:

- Safety-class SSCs

- $\quad$ MHM interlocks (P3, P8) and sensors - Ensure that the MHM turret is rotated to the navigate (TV camera) position prior to allowing power to the bridge or trolley drive motors when an MCO is in the MHM; the interlock circuitry includes contactors and relays, switches, and sensors (resolver, limit switches)

- $\quad$ MHM interlocks (P26, P80, P85) and sensors - Prevent the MHM from rotating to the MCO position while over the maintenance pit when an MCO is in the MHM; the interlock circuitry includes contactors and relays, and sensors (limit switches, photoelectric switches)

- Safety-significant SSCs

- MHM and MHM MCO hoist - Required by DOE Order 6430.1A and NRC equivalency important-to-safety Category B for SSCs that handle SNF

- TSR

- Operability of interlocks and sensors (P3, P8, P26, P80, P85); the interlock circuitry includes contactors, relays, and sensors (resolvers, limit switches, photoelectric switches). 
The drop of the cask-MCO from the receiving crane into the FFTF pit or the MHM maintenance pit could lead to the loss of criticality geometry control of the fuel in the MCO. The following are the specific safety SSCs and TSR controls that prevent this event:

\section{- Safety-class SSCs}

- Receiving crane positioning/interlock control system - Remove power to the receiving crane to prevent the receiving crane from traveling over the FFTF or maintenance pit when the receiving crane is carrying an MCO loaded with SNF

- TSRs

- Administrative use of the supervisor-controlled fortress key for movement of receiving crane over or east of the FFTF pit when there is no cask-MCO loaded with SNF suspended from the crane

- Operability of receiving crane resolver and interlock.

The drop of a CSB structural component onto an MCO or other safety-class structure could lead to the loss of criticality geometry control of the fuel in the MCO. The following are the specific safety SSCs and TSR controls that prevent this event:

\section{- Safety-class SSCs}

- Standard and overpack storage tubes, carbon steel base slab embeds, tube base assemblies, operating deck, and vault - Provide criticality geometry control and passive cooling and are seismically qualified to ensure structural integrity for all design basis NPHs

- Safety-significant SSCs

- Operating area shelter - Seismically qualified and tornado hardened to provide structural integrity for all design basis NPHs (waiver 1 to HNF-PRO-704)

- Rail frogs, rails, MHM seismic restraints, MHM (structural) - Prevent the MHM from falling onto the operating deck during DBA seismic events (waiver 2 to HNF-PRO-704)

- Operating shelter - protect operating deck from structural failure of the operating area shelter during DBA seismic events.

\section{TSR}

- Independent verification that the rail frogs are installed and secure. 
The break of an exterior water line and the subsequent erosion and softening of soil around the CSB would weaken the structural integrity of the building such that it may no longer be able to withstand a seismic event. The following are the specific safety SSCs and TSR controls that prevent this event:

- Safety-class SSCs

$$
\text { - None }
$$

- TSRs

- Periodic walkdowns of the facility to ensure that the soil-structure interaction assumptions are protected

- Walkdowns of the facility after operating basis earthquakes.

The drop of an MCO into or onto the edge of a storage tube could lead to the loss of criticality geometry control of the fuel in the MCO. These drops are both mitigated by the installation of one or more impact absorbers in each storage tube. These impact absorbers limit the deceleration of a maximum weight MCO dropped from the maximum height in the MHM to less than $35 \mathrm{~g}$. This has been recently determined to be incredible. The following are the specific safety SSCs and TSR controls that prevent this event:

- Safety-class SSCs

- Storage tube bottom impact absorber - Limits deceleration forces to less than $35 \mathrm{~g}$ for a maximum-weight MCO if the MCO is dropped from the MHM into or onto the storage tube

- Interface guide ring - Limits forces on the standard storage tube, operating deck, and the MCO within acceptable criteria during MCO drop events (eccentric)

- Safety-significant SSCs

- Storage tube intermediate impact absorber - Limits forces to the bottom of the dropped MCO and the top of the bottom MCO if a second MCO is dropped into a storage tube

- TSRs

- Bottom impact absorber is installed in each storage tube prior to placing an $\mathrm{MCO}$ in the storage tube 
- Intermediate impact absorber is installed in each storage tube prior to placement of a second $\mathrm{MCO}$ in that storage tube

- Interface guide ring is in place before arrival of the MHM over a storage tube if the MHM is carrying an MCO.

The drop of an MCO into the sampling/weld station could lead to the loss of criticality geometry control of the fuel in the MCO. This drop is mitigated by the installation of an impact absorber in the sampling/weld station pit that limits the deceleration of a maximum weight MCO dropped from the maximum height in the MHM to less than $35 \mathrm{~g}$. The following are the specific safety SSCs and TSR controls that prevent this event:

- Safety-class SSCs

- Sampling/weld station impact absorber - Limits deceleration forces to the MCO if the MCO is dropped from the MHM into the sampling/weld station pit

- TSR

- Sampling/weld station impact absorber is installed in the pit prior to placing an MCO in the sampling/weld station.

\subsubsection{Possible Rearrangement of Multi-Canister Internals Because of Collision}

A collision of the MHM with the transportation cask when the cask is partially inserted into the service station pit by the receiving crane could lead to the loss of criticality geometry control of the fuel in the MCO. Calculations demonstrate that the cask provides adequate protection to the MCO in this accident (Petersen 1998). The following is the specific safety SSC that prevents this event:

- Safety-class SSCs

- Transportation cask - Provide structural protection for the MCO when the $\mathrm{MCO}$ is inside the cask.

No TSR controls are needed for this accident. 


\section{SNF-3328 REV 0}

\subsubsection{Possible Rearrangement of Multi-Canister Internals Because of Gas Cylinder Impact.}

The impact of a compressed gas cylinder (missile) with the cask-MCO or an exposed portion of the MCO presents an unknown hazard to the MCO. All compressed gas cylinders contain a flow-limiting orifice installed within the neck of the bottle so that the bottle may not become a missile unless this orifice is deliberately removed. No calculations were performed to determine the damage that an MCO might sustain if it were struck by a damaged compressed gas cylinder that did not contain a flow-limiting orifice, but the hazard analysis assumed that such damage might lead to a gaseous release with safety-significant consequences. No credible accident will remove the flow-limiting orifice, so these cylinders will not present missile hazards. The following is the specific programmatic control that prevents this event:

- Programmatic control

- Site maintenance program does not support maintenance on compressed gas cylinders; consequently, maintenance on gas cylinders is done by the suppliers.

\subsection{REFERENCES}

10 CFR 72, 1995, "Lizensing Requirements for the Independent Storage of Spent Nuclear Fuel and High-Level Radioactive Waste," Code of Federal Regulations.

ASME NOG-1, 1989, Rules for Construction of Overhead and Gantry Cranes (Top Running Bridge, Multipie Girder), American Society of Mechanical Engineers, New York, New York.

CSB-S-0007A, 1996, Storage Tube Analysis Confirmation, Fluor.Daniel Hanford, Incorporated, Richland, Washington.

DOE Order 6430.1A, 1989, General Design Criteria, U.S. Department of Energy, Washington, D.C.

HNF-1896, 1998, Multi-Canister Overpack Basemat Deformations and Damage During a Horizontal Slop Down onto the Canister Storage Building Receiving Floor, Rev. 0, Fluor Daniel Hanford, Incorporated, Richland, Washington.

HNF-3553, 1999, Spent Nuclear Fuel Project Final Safety Analysis Report, Rev. 0, Fluor Daniel Hanford, Incorporated, Richland, Washington.

HNF-PRO-704, Hazard and Accident Analysis Process, Fluor Daniel Hanford, Incorporated, Richland, Washington. 
HNF-S-0426, 1997, Performance Specification for Spent Nuclear Fuel Multi-Canister Overpack, Rev. 3, Fluor Daniel Hanford, Incorporated, Richland, Washington.

HNF-SD-SNF-CSER-005, 1997, Criticality Safety Evaluation Report for Spent Nuclear Fuel Processing and Storage Facilities, Rev. 3, Fluor Daniel Hanford, Incorporated, Richland, Washington.

HNF-SD-SNF-CSER-010, 1998, Criticality Safety Evaluation Report for the K Basin Fuel Retrieval Subproject, Rev. 0, Fluor Daniel Hanford, Incorporated, Richland, Washington.

HNF-SD-SNF-DP-007, 1997, Multi-Canister Overpack/Cask Drop Analysis File Documentation, Rev. 0, Fluor Daniel Hanford, Incorporated, Richland, Washington.

HNF-SD-SNF-DP-010, 1997, Cask and MCO Drop onto the Transport Trailer Edge with Subsequent Horizontal Slap Down onto the CSB Receiving Area Floor, Rev. 0, Fluor Daniel Hanford, Incorporated, Richland, Washington.

HNF-SD-SNF-HIE-001, 1998, Canister Storage Building Hazard Analysis Report, Rev. 1, Fluor Daniel Hanford, Incorporated, Richland, Washington.

HNF-SD-SNF-SARR-005, 1998, Multi-Canister Overpack Topical Report, Rev. 1, Fluor Daniel Hanford, Incorporated, Richland, Washington.

HNF-SD-SNF-TI-015, 1998, Spent Nuclear Fuel Project Technical Databook, Rev. 5, Fluor Daniel Hanford, Incorporated, Richland, Washington.

HNF-SD-TP-SARP-017, 1997, Safety Analysis Report for Packaging (Onsite) Multicanister Overpack Cask, Rev. 0, Fluor Daniel Hanford, Incorporated, Richland, Washington.

NUREG/CR-6407, 1996, Classification of Transportation Packaging and Dry Spent Fuel Storage System Components According to Importance to Safety, U.S. Nuclear Regulatory Commission, Washington, D.C.

Petersen, S. L. 1998, MHM Collision with Cask/MCO (Transmittal FDT-137 to A. S. Daughtridge, D\&ES Hanford, November 30), Fluor Daniel, Incorporated, Richland, Washington.

WHC-SD-SNF-DB-009, 1996, Canister Storage Building Natural Phenomena Hazards, Rev. 4, Westinghouse Hanford Company, Richland, Washington. 
SNF-3328 REV 0

This page intentionally left blank. 


\subsection{CALCULATIONS FOR GASEOUS RELEASE FROM THE MULTI-CANISTER OVERPACK}

\subsection{PURPOSE AND OBJECTIVES}

At the Cold Vacuum Drying Facility (CVDF), the multi-canister overpack (MCO) is backfilled to a prescribed pressure, using helium, just before it is sealed for shipment to the Canister Storage Building (CSB). The MCO's internal pressure can increase, as a function of time, because of the radiolytic decomposition of water and aluminum hydroxide inside the MCO and the release of hydrogen from the chemical reaction of water with metallic fuel. Uncontrolled release of this MCO internal gas pressure, referred to as a gaseous release, is an operational accident resulting from failure of MCO sampling system equipment and/or operator error during the MCO sampling process. The purpose of this document is to calculate the potential gaseous release dose consequences from an $\mathrm{MCO}$ in the CSB sampling/weld station. The accident analyzed is a release of $\mathrm{MCO}$ internal gases resulting from failure of sampling system pressure bounding integrity during the time that a sample is being taken from an MCO.

\subsection{SCENARIO DEVELOPMENT}

The CSB hazard analysis (HNF-SD-SNF-HIE-001) identifies and categorizes a series of potential accidents as $\mathrm{MCO}$ pressurized gaseous release accidents. The general sequence of events leading to a gaseous release event is shown in Figure 3-1. The gaseous release accidents, illustrated in Figure 3-2, include leaks in the process system caused by dropping or crashing equipment into the process system equipment, by random failures of the process equipment, or by operator error. These gaseous release events specifically include four potential events:

- Shear of sampling lines connected to the MCO because of collision (e.g., with crane, service cart) (hazard analysis checklist entry WS-F-05)

- Shear of sampling lines connected to the MCO because of impact of a gas cylinder that becomes a missile (hazard analysis checklist entry WS-F-06)

- Damage to the MCO, when the cover port is removed for the purpose of sampling, because of dropped equipment (e.g., hoods, sampling equipment, pit covers) (hazard analysis checklist entry WS-G-03)

- Overpressurization of the MCO, sampling system, and/or inerting system because of high gas pressure resulting from failure of the sampling system helium supply pressure regulator (hazard analysis checklist entry WS-H-06).

This set of accidents involves a pressurized MCO exhausting, ultimately, to the environment as a result of an upset condition during the MCO sampling process. All accidents in this set have been assigned the same severity and frequency categories (S2/F2). 
MCOs arrive at the CSB from the CVDF in a mechanically sealed configuration and having no pressure safety devices. The majority of the MCOs will simply be placed in interim storage after being welded closed, but a relatively small fraction of them will be designated as monitored MCOs.

A monitored $\mathrm{MCO}$ is transferred by the $\mathrm{MCO}$ handling machine from the storage tube to the sampling/weld station for sampling. At the sampling/weld station, the MCO wall temperature is checked via an optical pyrometer, the $\mathrm{MCO}$ gas pressure and temperature are checked, and the MCO gas stream is sampled for hydrogen and oxygen and for radiological particulate and gases. After sampling is completed, the MCO gas pressure is re-established to the prescribed pressure with inert gas if the MCO pressure is less than the prescribed pressure. The MCO mechanical seal and cover plate seal can then be leak-tested to confirm seal integrity.

Once the sampling program has been completed, the monitored MCOs will eventually be transferred back to the sampling/weld station to have the cover cap welded in place. The MCO cover cap encloses all of the potential leak paths from the MCO through mechanical seals on the shield plug and process valves. MCOs not designated for monitoring activities will have the cover cap welded on immediately after receipt at the CSB; they will go directly from the MCO service station to the sampling/weld station and will not be installed in storage tubes before welding.

Accidents identified in the CSB hazard analysis as checklist entries WS-F-05 and WS-F-06 are gaseous release events resulting from failures of the MCO sampling system or sampling system process that result in blowing down a pressurized MCO (HNF-SD-SNF-HIE-001). The conceptual design of the MCO sampling/weld station (Petersen 1998), which includes the MCO sampling system, specifies that one process line will be connected to the short tube process port of the MCO (under cover plate 2). The line will be used to draw a sample of gas from within the $\mathrm{MCO}$ and to repressurize the MCO to a prescribed pressure using helium from the $120 \mathrm{lb} / \mathrm{in}^{2}$ gauge CSB helium supply system. The sampling system piping between the refill valve and the MCO will be pressurized to a maximum of the prescribed pressure value during this $\mathrm{MCO}$ refill operation. A rupture of this process line while the line is connected to the MCO and the MCO process valve is open would result in blowdown of the MCO. Because only one process line is connected to the $\mathrm{MCO}$, it is not possible to establish a flow path through the MCO so as to feed and bleed the $\mathrm{MCO}$ and remove particulate from the $\mathrm{MCO}$ for an extended period of time. To get a substantial release from the CSB, the MCO internal filter must be failed open and the break must occur in a section of process piping upstream of the sampler's high-efficiency particulate air (HEPA) filter (or the sampler's HEPA filter must be assumed to be failed open for a break location downstream of the sampler's HEPA filter). The entire sampling process is a manual operation and the technician taking the sample is present at all times.

Hazard analysis checklist entry WS-G-03 involves equipment dropping onto the top of the MCO during the short time that the port cover is removed and the valve operator is not installed (HNF-SD-SNF-HIE-001). To cause a release, the dropped object must be small enough to fit into the MCO shield plug cavity and hit the port valve and massive enough to damage the valve to the extent that a substantial leak ensues. Such equipment has not been identified, so this event is considered not credible. 
Hazard analysis checklist entry WS-H-06 involves pressurizing the MCO from the CSB helium supply system to the extent that the MCO design pressure is exceeded, thereby failing the MCO (HNF-SD-SNF-HIE-001). This event requires (1) a failure of the pressure regulator that regulates the sampling system inert gas supply pressure to $120 \mathrm{lb} / \mathrm{in}^{2}$ gauge, (2) a failure of the safety relief valve (set to relieve at $135 \pm 10 \% \mathrm{lb} / \mathrm{in}^{2}$ gauge), and (3) an undetected failure of the sampling system refill regulator. If the MCO is pressurized because of regulator failures, the pressurized helium supply piping of the sampling system could carry helium to the safety relief valve but there would be no flow path through the MCO. The safety valve will close when the helium supply is exhausted or interrupted, and there will be no release of radioactive material from the MCO. Therefore, this event is not considered for dose calculations.

The bounding gas release event is, therefore, failure of the sampling system pressure bounding during sampling. The magnitude of the radioactive release and subsequent dose associated with this type of accident is a function of the MCO's particulate loading at the time of the event.

The sampling process begins when the MCO handling machine lowers the selected monitored MCO into the sampling/weld station pit. The MCO's surface temperature is monitored. If the MCO's top surface temperature is sufficiently high, the MCO is cooled using the sampling/weld station cooling cap to reduce the temperature consistent with Occupational Safety and Health Administration limits. After installing temporary radiation shields and guard rails, the sampling hood is installed on the MCO to confine possible airborne contamination generated by an accidental release during sampling. The MCO sampling cart is connected to the local distributed control system and inert gas connections. The sampling cart's piping to the sample gas accumulator is connected to the sampling hood's HEPA filter outlet using a quick-disconnect, and the sample cart vent's flexible hose is connected to the sampling hood discharge, which dumps to the exhauster. This exhaust system fan is turned on to establish a negative pressure relative to the operating area atmosphere inside the sampling hood to maintain air contamination control around the top of the MCO.

An MCO process valve operator is installed on the short tube port of the MCO (port 2) after the cover plate is removed. The process valve operator is connected, with a quickdisconnect coupling, to a flexible hose that connects to the inlet of the sampler's HEPA filter. The remainder of the sample system piping is (1) the flexible pipe that connects the outlet of the sampler's HEPA filter to the sample cart and (2) the rigid pipe in the sample cart that attaches to the sample valve and the sample accumulator.

A leak in the confines of the sample hood would be quickly exhausted through the sampling/weld station HEPA filter or exhauster to the CSB exhaust system plenum and out to the environment through the CSB stack. Leaks from the sample system outside of the sample hood would be to the CSB atmosphere.

The effective leak flow area is bounded by the flow area of the path through the MCO shield plug, which is a 1.0-in.-diameter hole. All of the sampling system piping outside of the sampling hood is less than or equal to 0.75 -in. diameter. The flexible hose inside the sample hood is 
nominal 1.0-in. diameter; a break of that hose could result in an approximately 1.0-in. diameter flow path from the MCO. This maximum leak path could also occur if the valve operator body is improperly secured to the top of the MCO. Therefore, the largest leak flow path area would be a leak into the sample hood. Sampling system leaks outside of the sample hood would have smaller flow area paths and would have traveled through the sampler's HEPA filter.

\subsection{SOURCE TERM ANALYSIS}

Section 4.4.2.3.2, page 4-73, of DOE-HDBK-3010-94, Airborne Release Fractions/Rates and Respirable Fractions/Rates for Nonreactor Nuclear Facilities, documents airborne release fractions and respirable fractions. These fractions are derived from experiments in which pressurized gases are vented through powders. Such venting is similar to that of an MCO blowing down because of a significant leak in the MCO sampling system pressure boundary. Based on the data reported in DOE-HDBK-3010-94 for pressures of $0.17 \mathrm{MPAg}$ and less, a conservative airborne release fraction of $5 \times 10^{-3}$ is assessed to be bounding. This value from DOE-HDBK-3010-94 is commensurate with the value for accelerated airflow parallel to surface, which could be the dominant effect for low-pressure venting powder. The limiting respirable fraction of 0.4 is considered to be appropriate (DOE-HDBK-3010-94).

For the gaseous release accident, the particulate available for release would be generated after the fuel is washed and could be very similar to powder lying on a heterogeneous surface. The contents of the MCO are intact fuel elements tightly packed in the fuel baskets and the pieces of fuel elements housed in the scrap basket. Particulate matter swept up by the streams of flowing gas within the MCO does not simply enter the general CSB airspace to be available for dispersion in the environment. Once a particle is swept up by the flowing gas, it must take a tortuous path through the rest of the MCO and through the MCO shield plug to exit the MCO.

The MCO gaseous release accident could only happen within the first year after an MCO is loaded, based on the schedule for sampling MCOs. HNF-3048, Post Fuel-Cleaning Corrosion of Uranium within MCO Payloads, states that the bounding value for the mass of particulate at the end of the first year is $34.0 \mathrm{~kg}$ of uranium dioxide, which contains $30.0 \mathrm{~kg}$ of uranium.

The gaseous release event with the bounding particulate release from the MCO would be that which results from a leak close to the MCO through a leak path with a flow area greater than or equal to the flow area through the MCO shield plug. This could be the result of a complete severance of the pipe or flexible tubing within the sampling/weld station sample hood or failure to tighten the hold down bolts on the MCO port valve operator. For a leak path flow area of this size, the MCO would depressurize to atmospheric pressure in less than a minute (SNF-2770, Figure 7-4), even for an MCO pressure of about $75 \mathrm{lb} / \mathrm{in}^{2}$ gauge. The MCO would depressurize in a much shorter time for MCO pressure values less than $10 \mathrm{lb} / \mathrm{in}^{2}$ gauge, which are very likely to be the case.

The $\mathrm{MCO}$ gases and any radioactive particulate matter released from the $\mathrm{MCO}$ during this event would be released through the MCO shield plug port, which contains the internal HEPA 
filter. Because the internal HEPA filter is not testable, it is assumed to be failed open for this event and not inhibiting entrained particulate matter escaping from the MCO into the sampling/weld station sample hood. The MCO sampling/weld station heating, ventilation, and air conditioning system draws air through the sampling/weld station hood at the rate of 100 to $250 \mathrm{ft}^{3} / \mathrm{min}$ into a filter train and then blows the air into the CSB exhaust system plenum. This air then goes up the exhaust stack and is released to the environment.

The amount of respirable material released during the blowdown from the MCO will be calculated using the following formula:

$$
\mathrm{Q}=(\mathrm{MAR})(\mathrm{ARF})(\mathrm{RF})(\mathrm{LPF})
$$

where

$$
\begin{aligned}
& \mathrm{MAR}=\text { material at risk }(30.0 \mathrm{~kg}) \\
& \mathrm{ARF}=\text { airborne release fraction }\left(5.0 \times 10^{-3}\right) \\
& \mathrm{RF}=\text { respirable fraction }(0.4) \\
& \mathrm{LPF}=\text { leak path factor (conservatively set to } 1.0) .
\end{aligned}
$$

For this event, the amount of respirable radionuclide material released is

$$
\begin{aligned}
\mathrm{Q} & =(30.0 \mathrm{~kg})(1,000 \mathrm{~g} / \mathrm{kg})(1.0)\left(5.0 \times 10^{-3}\right)(0.4)(1.0) \\
& =60 . \mathrm{g} .
\end{aligned}
$$

\subsection{CONSEQUENCE ANALYSIS}

The radiological dose (effective dose equivalent) to a receptor is calculated by using the following equation:

$$
\operatorname{EDE}=(M)\left(\frac{\chi}{Q^{\prime}}\right)(B R)(U D)
$$

where

$\mathrm{EDE}=$ the effective dose equivalent, in rem

$\mathrm{M}=$ the respirable quantity released into the air, in grams

$X / Q^{\prime}=$ the air transport factor, $s / \mathrm{m}^{3}$ (see Table 3-1)

$\mathrm{BR}=$ the average inhalation rate during the release, $\mathrm{m}^{3} / \mathrm{s}$

$\mathrm{UD}=$ the committed effective dose equivalent per unit gram inhaled. 
Table 3-1. Maximum Individual Locations and Air Transport Factors Used in the Calculations.

\begin{tabular}{|l|c|c|}
\hline \multicolumn{1}{|c|}{ Receptor location } & $\begin{array}{c}\text { Acute } \\
(<1 \text { hour })\end{array}$ & $\begin{array}{c}\text { Chronic } \\
\text { (annual) }\end{array}$ \\
\hline Onsite $(100 \mathrm{~m} \mathrm{ESE})$ & $3.41 \mathrm{E}-2$ & $4.03 \mathrm{E}-4$ \\
\hline Highway $240(10,510 \mathrm{~m} \mathrm{~W})$ & $2.01 \mathrm{E}-5$ & $1.07 \mathrm{E}-7$ \\
\hline Hanford Site boundary $(17,390 \mathrm{~m} \mathrm{E})$ & $1.30 \mathrm{E}-5$ & $7.98 \mathrm{E}-8$ \\
\hline
\end{tabular}

Note: Air transport factors are for ground level releases and the units are $\mathrm{s} / \mathrm{m}^{3}$. Values are taken from Table 1 of HNF-SD-SNF-TI-059, 1998, A Discussion on the Methodology for Calculating Radiological and Toxicological Consequences for the Spent Nuclear Fuel Project at the Hanford Site, Rev. 1, Fluor Daniel Hanford, Incorporated, Richland, Washington.

Radiological inhalation dose consequences for each set of accident conditions are analyzed based on the following assumptions:

- Breathing rate (BR) - The light activity breathing rate of $3.33 \times 10^{-4} \mathrm{~m}^{3} / \mathrm{s}$, as specified in HNF-SD-SNF-TI-059, A Discussion on the Methodology for Calculating Radiological and Toxicological Consequences for the Spent Nuclear Fuel Project at the Hanford Site, is used for all receptors.

- Dose conversion factor (UD) - The dose per unit of respirable material inhaled is $4.38 \times 10^{5} \mathrm{rem} / \mathrm{g}$ of fuel as specified in HNF-SD-SNF-TI-059. All the material released from the building is treated as respirable (i.e., less than $10 \mu \mathrm{m}$ aerodynamic diameter).

The duration of the release is taken to be less than one hour for all receptors. All of the air transport factors used in this analysis are summarized in Table 3-1. Using the respirable radionuclide release quantities and the air transport factors (see Table 3-1), doses to various receptors are calculated as demonstrated below. The results are summarized in Table 3-2.

Table 3-2. Summary of Dose Calculations (Unmitigated).

\begin{tabular}{|l|c|c|c|}
\hline \multicolumn{1}{|c|}{ Receptor location } & $\begin{array}{c}\text { Duration } \\
(\mathrm{h})\end{array}$ & $\begin{array}{c}\text { Air transport } \\
\text { factor }\end{array}$ & $\begin{array}{c}\text { Dose } \\
\text { (rem) }\end{array}$ \\
\hline Onsite $(100 \mathrm{~m} \mathrm{ESE})$ & $<1$ & $3.41 \mathrm{E}-2$ & 300.00 \\
\hline Highway $240(11,250 \mathrm{~m} \mathrm{NNW})$ & $<1$ & $2.01 \mathrm{E}-5$ & 0.18 \\
\hline Hanford Site boundary $(17,390 \mathrm{~m} \mathrm{E})$ & $<1$ & $1.30 \mathrm{E}-5$ & 0.11 \\
\hline
\end{tabular}


For the onsite collocated worker

$$
\begin{aligned}
E D E_{\text {Onsite }} & =(60.00 \mathrm{~g})\left(3.41 \times 10^{-2} \frac{\mathrm{s}}{\mathrm{m}^{3}}\right)\left(3.33 \times 10^{-4} \frac{\mathrm{m}^{3}}{\mathrm{~s}}\right)\left(4.38 \times 10^{5} \frac{\mathrm{rem}}{\mathrm{g}}\right) \\
& =300.00 \mathrm{rem}(3.0 \mathrm{~Sv}) .
\end{aligned}
$$

\subsection{COMPARISON TO GUIDELINES}

The U.S. Department of Energy-recommended radiological risk evaluation guidelines (Sellers 1997) are shown in Table 3-3. The annual frequency of a helium leak in the sampling system is estimated to be the sum of the frequency of a leak from the MCO sampling system pressure boundary configuration that exists during sampling. This includes (1) a leak resulting from failure to properly seal the MCO valve operator at the sampling/weld station; (2) leaks from the process line inside the sample hood; and (3) leaks from the process line outside the sample hood, which includes the piping in the sample cart (see Appendix A):

$$
\left(1 \times 10^{-2}\right)+\left(1.6 \times 10^{-5}\right)+\left(1.6 \times 10^{-5}\right) \approx 1 \times 10^{-2} / \text { year. }
$$

This places this event into the anticipated category.

Table 3-3. Radiological Evaluation Guidelines and Limits.

\begin{tabular}{|l|c|c|c|}
\hline \multicolumn{1}{|c|}{ Event category } & $\begin{array}{c}\text { Frequency range } \\
\text { (per year) }\end{array}$ & $\begin{array}{c}\text { Onsite risk evaluation } \\
\text { guidelines* } \\
\text { rem (Sv) }\end{array}$ & $\begin{array}{c}\text { Offsite accident } \\
\text { release limits* } \\
\text { rem (Sv) }\end{array}$ \\
\hline Anticipated & $1.0 \mathrm{E}-1$ to $1.0 \mathrm{E}-2$ & $1.0(0.01)$ & $0.5(0.005)$ \\
\hline Unlikely & $1.0 \mathrm{E}-2$ to $1.0 \mathrm{E}-4$ & $10.0(0.1)$ & $5.0(0.05)$ \\
\hline Extremely unlikely & $1.0 \mathrm{E}-4$ to $1.0 \mathrm{E}-6$ & $25.0(0.25)$ & $5.0(0.05)$ \\
\hline
\end{tabular}

Note: All doses committed effective dose eqquivalent.

*This terminology is consistent with Tables 1 and 2 of Sellers, E. D., 1997, Risk Evaluation Guidelines (REGs) to Ensure Inherently Safer Designs (Letter 97-SFD-172 to H. J. Hatch, Fluor Daniel Hanford, Incorporated, August 26), U.S. Department of Energy, Richland Operations Office, Richland, Washington.

The unmitigated radiological dose to the onsite worker from the gaseous release accident is calculated to be greater than the onsite risk evaluation guidelines for anticipated events. The dominant features of the CSB design in reducing doses associated with sampling system leak accidents are the HEPA filter train of the sample hood air system, which discharges to the CSB general exhaust system, and the HEPA filter on the sample line located on the sample hood. 
These filters will mitigate releases associated with breaches of the sample line inside and outside of the sample hood. These HEPA filters are specified to operate at $99.9 \%$ filter efficiency; thus the respirable quantity released into the air is reduced by a factor of 1,000 . The resultant mitigated dose for the bounding gaseous release accident is provided in Table 3-4.

Table 3-4. Summary of Dose Calculations (Mitigated).

\begin{tabular}{|l|c|c|c|}
\hline Receptor location & $\begin{array}{c}\text { Exposure time } \\
(\mathrm{h})\end{array}$ & $\begin{array}{c}\text { Air transport } \\
\text { factor }\end{array}$ & $\begin{array}{c}\text { Dose } \\
\text { rem (Sv) }\end{array}$ \\
\hline Onsite $(100 \mathrm{~m} \mathrm{E})$ & 1 & $3.41 \mathrm{E}-2$ & $0.3(0.003)$ \\
\hline
\end{tabular}

\subsection{SUMMARY OF SAFETY-CLASS STRUCTURES, SYSTEMS, AND COMPONENTS AND TECHNICAL SAFETY REQUIREMENT CONTROLS}

No safety-class structures, systems, and components (SSCs) are required to mitigate dose consequences from the two scenarios. The following safety-significant equipment and Technical Safety Requirement (TSR) controls are designated to mitigate the dose consequences of the bounding gaseous release accidents:

\subsubsection{Gaseous Release during the Multi-Canister Overpack Sampling Operation}

The release of MCO gases during the MCO sampling operation is due to a leak from the sampling system. Such a leak could be result from the sampling/weld station gantry crane, the MHM, or some other equipment moving horizontally into the sampling/weld station components and causing a shear of the piping or otherwise failing the sampling system pressure boundary. The following are the specific safety features and controls that prevent or mitigate this event:

- Safety-significant SSCs

- MHM interlock (P10), sensors, and switches (MHM collision avoidance system) Removes power from MHM bridge trolley drive motors upon collision with the MCO sampling/weld station

- Seismic restraints on the sampling/weld station gantry crane - Prevent motion of the gantry crane when the gantry crane is in position over the $\mathrm{MCO}$ for sampling and the $\mathrm{MCO}$ is connected to the sampling system and the MCO port valve is open

- Sampling/weld station gantry crane bumper - Activate the MHM collision avoidance system 
- TSRs

- Verify operability of MHM interlock (P10), sensors, and switches

- Verify application of the seismic restraint on the gantry crane before connecting the sampling line to the $\mathrm{MCO}$

\subsubsection{Gaseous Release Resulting from Overpressurization of the Multi-Canister Overpack}

The release of $\mathrm{MCO}$ gases resulting from overpressurization of the $\mathrm{MCO}$ is caused by the inert gas system during reinerting of a monitored $\mathrm{MCO}$ after sampling. This accident is initiated by failure of the pressure regulator on the helium supply system while an $\mathrm{MCO}$ is in the sampling/weld station undergoing the MCO helium backfill operation. The following are the specific safety features and controls that prevent or mitigate this event:

- Safety-class SSCs

- Pressure safety valves - Provide protection from pressure internal to the MCO and the sampling system piping from exceeding design values of $450 \mathrm{lb} / \mathrm{in}^{2}$ gauge and $150 \mathrm{lb} / \mathrm{in}^{2}$ gauge, respectively, when sampling the MCO; there shall be at least two independent safety valves, each with the flow capacity to relieve the maximum flow rate of gas through a failed open pressure regulator

- TSR

- Two pressure safety valves, one on the MCO sampling system and one on the helium supply system, must be installed and operable.

In addition, the maintenance of gas cylinders is assumed to be controlled by the site/project maintenance program. This program will verify that the gas cylinders have orifice flow restrictors that prevent excessive gas flow from the cylinders. As such, a TSR is not required.

The SSCs and TSR controls designated to mitigate gaseous release accidents are summarized in Table 3-5. U.S. Nuclear Regulatory Commission important-to-safety category SSCs and defense-in-depth features also are included.

The suite of safety SSCs and TSR controls necessary and sufficient to prevent the two gaseous release accidents do not address some of the other accidents in the same accident category. Table 3-5 also lists the safety SSCs and TSR controls needed to prevent or control these accidents. Because these accidents are substantially different in development and progression from the design basis accidents, each scenario and the corresponding controls are also described below.

3.6.2.1 Pressurized Release. When at the service area, the transportation cask lid can be dropped onto the cask-MCO or the MCO can be dropped from the MHM either back into the 
Table 3-5. Summary of Safety Features Required to Mitigate the Consequences of a Gaseous Release Design Basis Accident. (4 sheets)

\begin{tabular}{|c|c|c|c|c|}
\hline Accident & $\begin{array}{l}\text { Checklist } \\
\text { designator }\end{array}$ & $\begin{array}{l}\text { General } \\
\text { function }\end{array}$ & Safety feature and safety classification ${ }^{b}$ & $\begin{array}{l}\text { NRC ITS } \\
\text { category }\end{array}$ \\
\hline \multicolumn{5}{|c|}{ Pressurized release from MCO } \\
\hline \begin{tabular}{|l} 
MCO \\
sampling \\
system \\
pressure \\
boundary \\
failure caused \\
by equipment \\
collision
\end{tabular} & $\begin{array}{l}\text { WS-F-02 } \\
\text { WS-F-05 }\end{array}$ & $\begin{array}{l}\text { Prevent } \\
\text { equipment, } \\
\text { moving } \\
\text { horizontally, } \\
\text { from damaging } \\
\text { the sampling } \\
\text { system } \\
\text { Mitigate } \\
\text { particulate } \\
\text { release from the } \\
\text { sampling/weld } \\
\text { station }\end{array}$ & $\begin{array}{l}\text { Safety-significant SSCS: } \\
\text { MHM interlock (PIO), sensors, and switches (MHMM } \\
\text { collision avoidance system) } \\
\text { - Seismic restraints on the sampling/weld station } \\
\text { gantry crane } \\
\text { - Sampling/weld station gantry crane bumper } \\
\text { TSRs: } \\
\text { - Verify operability of MHM interlocks, sensors, and } \\
\text { switches (P10) } \\
\text { - Verify application of the seismic restraint on the } \\
\text { gantry crane prior to connecting the sampling line to } \\
\text { the MCO } \\
\text { Defense in depth: } \\
\text { - Personnel are trained to procedures detailing the safe } \\
\text { sequence of operations. } \\
\text { The frogs on the receiving crane's tracks have stops. } \\
\text { The operators of the MHM are trained and qualified } \\
\text { to perform their duties safely, which includes } \\
\text { following procedures for safe operation. } \\
\text { Regular maintenance is performed on the MHM to } \\
\text { ensure it is in good working order. }\end{array}$ & $\begin{array}{l}\text { NA } \\
\text { NA } \\
\text { NA }\end{array}$ \\
\hline $\begin{array}{l}\text { Overpressuri- } \\
\text { zation of MCO } \\
\text { and connecting } \\
\text { lines during } \\
\text { sampling }\end{array}$ & $\begin{array}{l}\text { WS-H-06a } \\
\text { WS-H-07 } \\
\text { WS-H-11 }\end{array}$ & $\begin{array}{l}\text { Protect the } \\
\text { sampling } \\
\text { system piping } \\
\text { and the MCO } \\
\text { from internal } \\
\text { pressure that } \\
\text { exceeds design } \\
\text { pressure }\end{array}$ & $\begin{array}{l}\text { Safety-class SSCs: } \\
\text { Helium system supply pressure safety valves } \\
\text { TSR: } \\
\text { Two pressure safety valves, one on the MCO } \\
\text { sampling system and one on the helium supply } \\
\text { system, must be installed and operable } \\
\text { Defense in depth: } \\
\text { Relief valve is tested. } \\
\text { - Glycol lines are low pressure. The pressure gauge } \\
\text { will fail at a lower pressure than the MCO. } \\
\text { Personnel are trained to facility-specific procedures } \\
\text { regarding transportation cask shipping, movement, } \\
\text { and handling. } \\
\text { A service area enclosure can be placed over the } \\
\text { service pit when higher than normal pressures are } \\
\text { detected in the transportation cask. } \\
\text { The service area enclosure, if in place, provides } \\
\text { HEPA-filtered confinement in the event of an MCO } \\
\text { pressure release. }\end{array}$ & A \\
\hline
\end{tabular}


Table 3-5. Summary of Safety Features Required to Mitigate the Consequences of a Gaseous Release Design Basis Accident. (4 sheets)

\begin{tabular}{|c|c|c|c|c|}
\hline Accident & $\begin{array}{l}\text { Checklist } \\
\text { designator" }\end{array}$ & $\begin{array}{l}\text { General } \\
\text { function }\end{array}$ & Safety feature and safety classification ${ }^{b}$ & $\begin{array}{l}\text { NRC ITS } \\
\text { category }^{b}\end{array}$ \\
\hline $\begin{array}{l}\text { Drop of the } \\
\text { MCO from the } \\
\text { MHM while } \\
\text { removing the } \\
\text { MCO from the } \\
\text { transportation } \\
\text { cask } \\
\text { or } \\
\text { Transportation } \\
\text { cask lid drop } \\
\text { onto the MCO }\end{array}$ & SA-G-03a & $\begin{array}{l}\text { Prevent the } \\
\text { MCO from } \\
\text { structural } \\
\text { deformation } \\
\text { that results in a } \\
\text { leak of MCO } \\
\text { internal gases } \\
\text { from the MCO }\end{array}$ & $\begin{array}{l}\text { Safety-significant SSCS: } \\
\text { - MCO shell, locking ring, and shield plug } \\
\text { - MCO service station impact absorber } \\
\text { Tent gantry hoist } \\
\text { ISRs: } \\
\text { - Impact absorber is installed in the MCO service } \\
\text { station pit and is operable } \\
\text { - Cask lid may only be removed by a crane and hoist } \\
\text { lifting device that physically cannot lift the lid more } \\
\text { than } 5 \text { ft above the top of the MCO. } \\
\text { Defense in depth: } \\
\text { The MHM grapple is designed with a mechanical } \\
\text { lock such that it should not be able to open while a } \\
\text { load is suspended from it. } \\
\text { - Personnel are trained to facility-specific procedures in } \\
\text { the proper handling of the transportation cask, MCO, } \\
\text { receiving crane, gantry, and MFM. } \\
\text { Lifting devices used at the CSB are designed to } \\
\text { handle the loads they will carry. }\end{array}$ & $\begin{array}{c}\mathrm{NA} \\
\text { NA } \\
\mathrm{C}\end{array}$ \\
\hline $\begin{array}{l}\text { Conrosion of } \\
\text { the MCO by } \\
\text { battery acid }\end{array}$ & OA-D-01 & $\begin{array}{l}\text { Prevent the } \\
\text { MCO from } \\
\text { sustaining } \\
\text { corrosion } \\
\text { damage that } \\
\text { results in a leak } \\
\text { of MCO } \\
\text { internal gases } \\
\text { from the MCO }\end{array}$ & $\begin{array}{l}\text { Safety-significant SSCS: } \\
\text { - Battery compartment of the tube vent and purge cart } \\
\text { Defense in depth: } \\
\text { - Periodic battery inspections are performed } \\
\text { - Written charging procedures are used } \\
\text { - Reputable battery vendor is used }\end{array}$ & B \\
\hline
\end{tabular}


Table 3-5. Summary of Safety Features Required to Mitigate the Consequences of a Gaseous Release Design Basis Accident. (4 sheets)

\begin{tabular}{|c|c|c|c|c|}
\hline Accident & $\begin{array}{r}\begin{array}{r}\text { Checklist } \\
\text { designator" }\end{array} \\
\end{array}$ & $\begin{array}{r}\text { General } \\
\text { function }\end{array}$ & Safety feature and safety classification ${ }^{b}$ & $\begin{array}{l}\text { NRC ITS } \\
\text { category }^{\text {b }}\end{array}$ \\
\hline $\begin{array}{l}\text { MCO } \\
\text { sampling } \\
\text { system } \\
\text { pressure } \\
\text { boundary } \\
\text { equipment } \\
\text { drop }\end{array}$ & $\begin{array}{l}\text { WS-G-01 } \\
\text { WS-G-03b } \\
\text { WS-G-04 } \\
\text { WS-G-06 }\end{array}$ & $\begin{array}{l}\text { Prevent falling } \\
\text { objects from } \\
\text { falling into the } \\
\text { sampling } \\
\text { system } \\
\text { components } \\
\text { Mitigate } \\
\text { particulate } \\
\text { release from the } \\
\text { sampling/weld } \\
\text { station }\end{array}$ & $\begin{array}{l}\text { Safety-significant SSCs: } \\
\text { - Seismic restraints on the sampling/weld station } \\
\text { gantry crane } \\
\text { Sample hood/sample hood exhaust system } \\
\text { - Sample line HEPA filter } \\
\text { TSRs: } \\
\text { - Perform a pressure-test of the port valve } \\
\text { operator/MCO shield plug seal and of the sampling } \\
\text { system pressure boundary within the sample hood up } \\
\text { to and including the sampling line HEPA filter } \\
\text { Verify the air flow rate through the sampling hood } \\
\text { - Independent verification of pressure test of the } \\
\text { sampling system pressure boundary integrity } \\
\text { - Independent verification that the MCO port valve is } \\
\text { properly closed prior to removal of the port valve } \\
\text { operator from the MCO shield plug } \\
\text { Defense in depth: } \\
\text { - The MIMM grapple is designed with a mechanical } \\
\text { lock such that it should not be able to open while a } \\
\text { load is suspended from it. } \\
\text { Personnel are trained to facility-specific procedures in } \\
\text { the proper handling of the transportation cask, MCO, } \\
\text { receiving crane, gantry, and MHM. } \\
\text { The sampling/weld station gantry crane bumper } \\
\text { activates the MHM anticollision system to prevent } \\
\text { collisions with the sample hood and sample lines. } \\
\text { - Lifting devices used at the CSB are designed to } \\
\text { handle the loads they will carry. }\end{array}$ & $\begin{array}{l}\text { NA } \\
\text { NA } \\
\text { NA } \\
\text { NA }\end{array}$ \\
\hline $\begin{array}{l}\text { Gaseous } \\
\text { release from } \\
\text { failure of the } \\
\text { sampling } \\
\text { system } \\
\text { pressure } \\
\text { boundary } \\
\text { caused by } \\
\text { damage from } \\
\text { high-pressure } \\
\text { gas cylinders }\end{array}$ & WS-F-06 & $\begin{array}{l}\text { Prevent high- } \\
\text { pressure gas } \\
\text { cylinders from } \\
\text { becoming } \\
\text { dangerous } \\
\text { missiles in the } \\
\text { CSB }\end{array}$ & $\begin{array}{l}\text { Safety-significant SSCs: } \\
\text { A flow-restricting orifice in the neck of gas cylinders } \\
\text { TSR: } \\
\text { A TSR is not required. Site/project maintenance } \\
\text { program will control maintenance involving gas } \\
\text { cylinders which will verify that the gas cylinders } \\
\text { have orifice flow restrictors. Only cylinder suppliers } \\
\text { perform maintenance. } \\
\text { Defense in depth: } \\
\text { Operators are trained in the proper handling of } \\
\text { compressed gas cylinders according to established } \\
\text { procedures } \\
\text { - Gas cylinders have flow restrictors to linit forces } \\
\text { from gas exiting the cylinder } \\
\text { - Gas cylinders supplying the inert gas system are } \\
\text { located outside of the CSB }\end{array}$ & NA \\
\hline \multicolumn{5}{|c|}{ Possible release from cask-MCO } \\
\hline
\end{tabular}




\section{Table 3-5. Summary of Safety Features Required to Mitigate the Consequences of a} Gaseous Release Design Basis Accident. (4 sheets)

\begin{tabular}{|c|c|c|c|c|}
\hline Accident & $\begin{array}{l}\text { Checklist } \\
\text { designator }\end{array}$ & $\begin{array}{l}\text { General } \\
\text { function }\end{array}$ & Safety feature and safety classification ${ }^{b}$ & $\begin{array}{l}\text { NRC ITS } \\
\text { category }\end{array}$ \\
\hline $\begin{array}{l}\text { Drop of the } \\
\text { transportation } \\
\text { cask-MCO } \\
\text { from the } \\
\text { receiving crane } \\
\text { causing a } \\
\text { release of } \\
\text { particulate } \\
\text { from the } \\
\text { transportation } \\
\text { cask }\end{array}$ & TV-G-13 & $\begin{array}{l}\text { Preclude the } \\
\text { release of } \\
\text { particulate by } \\
\text { proper design of } \\
\text { the MCO and } \\
\text { transportation } \\
\text { cask and to } \\
\text { handle the } \\
\text { transportation } \\
\text { cask within the } \\
\text { design basis } \\
\text { parameters }\end{array}$ & $\begin{array}{l}\text { Safety-significant SSCS: } \\
\text { - MCO shell, locking ring, and shield plug } \\
\text { Transportation cask } \\
\text { TSeceiving crane lifting yoke (length) } \\
\text { TSR: } \\
\text { Defense in depth: } \\
\text { - Transportation cask confinement of radionuclides } \\
\text { - Qualified crane operators. } \\
\text { provintenance and operations manuals and details are } \\
\text { - The hoist design includes. } \\
\text { - Interlocks to preclude lift and horizontal motion at } \\
\text { same time } \\
\text { - Dual brakes } \\
\text { - No free fall capacity. } \\
\text { Lifting devices used at the CSB are designed to } \\
\text { handle the loads they will carry. } \\
\text { - Personnel are trained to facility-specific procedures in } \\
\text { the proper handling of the transportation cask, MCO, } \\
\text { receiving crane, and MHM. }\end{array}$ & $\begin{array}{l}B \\
B \\
B\end{array}$ \\
\hline
\end{tabular}

"Checklist designators are from HNF-SD-SNF-FIE-001, 1999, Canister Storage Building Hazard Analysis Report, Rev. 1, Fluor Daniel Hanford, Incorporated, Richland, Washington. DBA category.

"The pressure control valve on the helium supply system fails open and causes the inside of the sampling system piping and the MCO to be exposed to helium source pressure that is in excess of the sampling system and the MCO design pressure values.

Battery acid spills from the service cart battery to the operating deck, falls into the storage tube plug and corrodes the tube plug seal, drops onto the MCO, and corrodes through the wall of the MCO causing the release of MCO internal gases.

CSB = Canister Storage Building.

DBA $=$ design basis accident.

HEPA $=$ high-efficiency particulate air (filter).

ITS $=$ important to safety.

$\mathrm{MCO}=$ multi-canister overpack

MHM = multi-canister overpack handling machine.

NA = not applicable to ITS category classification.

$\mathrm{NRC}=$ U.S. Nuclear Regulatory Commission.

SSC = structure, system, and component.

TSR $=$ technical safety requirement. 
transportation cask or onto the edge of the cask as the $\mathrm{MCO}$ is being raised out of the cask into the travel position in the MHM. If the MCO is dropped onto the edge of the cask, the falling distance from the maximum possible elevation of the MCO in the MHM to the top of the transportation cask is approximately $8 \mathrm{ft}$. The MCO is designed to maintain its integrity following such a drop (HNF-SD-SNF-DP-010). The MCO can also be dropped from the maximum possible height in the MHM to the bottom of the transportation cask; a distance of about $21.2 \mathrm{ft}$. An impact absorber in the MCO service station pit, located under the cask, will absorb energy of the falling $\mathrm{MCO}$ and prevent damage to the $\mathrm{MCO}$ that could result in the release of $\mathrm{MCO}$ gas (HNF-SD-SNF-DP-010). The following are the specific safety features and controls that prevent or mitigate this event:

- Safety-significant SSCs

- MCO shell, locking ring, and shield plug - Provide structural protection and confinement of the SNF when SNF is in an open transportation cask, in the MHM, or being transferred from the transportation cask to the MHM

- MCO service station impact absorber - Limits deceleration forces to the MCO to $35 \mathrm{~g}$ if the MCO is dropped from the MHM back into the transportation cask; must be installed and operable when the MCO is being lowered into or being raised from the service station pit

- Tent gantry hoist - Physically limits the cask lid from being lifted more than $5 \mathrm{ft}$ above the top of the MCO

- TSRs

- Impact absorber is installed in the MCO service station pit and is operable

- Cask lid may only be removed by a crane and hoist lifting device that physically cannot lift the lid more than $5 \mathrm{ft}$ above the top of the MCO.

The tube vent and purge cart performs normal and recovery-related activities. It is hypothesized that acid (the electrolyte) from the battery on the cart could fall from the cart onto the operating deck in the vicinity of a storage tube cover, leak through the gap around the cover, leak through the storage tube plug seal, and drip onto the MCO. This acid could then chemically react with the MCO shell and corrode a hole in the MCO shell, resulting in the release of MCO gases. The following are the specific safety features that prevent or mitigate this event:

- Safety-significant SSCs

- Battery compartment of the tube vent and purge cart - Contains battery acid within the compartment when the cart is in the operating area; it will be fabricated from material that will not chemically react with battery acid and has the capacity to contain the entire acid inventory of the battery for an indefinite period of time when the cart is in the operating deck area or in the service area of the CSB 
The drop of an object onto the sampling/weld station components is another cause of a leak from the sampling system. Such a drop could shear the sampling system piping or otherwise fail the confinement capability of the sampling system pressure boundary. Safety-significant confinement by the sample hood, sample hood duct, and the sample hood exhaust HEPA filter is required. The exhaust fan associated with this exhaust system must be verified to be operating before opening the MCO port valve. It is not necessary to have safety-significant electric power for the fan because the loss of sample hood exhaust flow due to loss of electric power or mechanical failure coincident with a sampling system leak inside the sample hood is not credible. The following are the specific safety features and controls that prevent or mitigate this event. The following SSCs and TSRs are also designed to protect against operator error in connecting the sampling system to the $\mathrm{MCO}$, against failure of sampling components, and against motion of the gantry crane that could damage the sampling apparatus:

- Safety-significant SSCs

- Seismic restraints on the sampling/weld station gantry crane - Prevent motion of the gantry crane when the gantry crane is in position over the $\mathrm{MCO}$ for sampling and the MCO is connected to the sampling system and the MCO port valve is open

- Sample hood and sample hood exhaust system - Provides confinement of radioactive particulate by sweeping any particulate released from the $\mathrm{MCO}$ into the exhaust system HEPA filter train; the HEPA filter must be rated to operate at a minimum of $99.9 \%$ efficiency, as assumed in the safety analysis, and be aerosol tested semiannually; this system must be operating when the $\mathrm{MCO}$ is in the sampling/weld station pit and the MCO is connected to the sampling system and the MCO port valve is open; minimum air flow rate of $5 \mathrm{ft}^{3} / \mathrm{min}$ is required to entrain respirable particulate and move it into the HEPA filter

- Sample line HEPA filter - Provides confinement of particulate released from the MCO during the sampling operation; must be operable when the MCO is in the sampling/weld station and the MCO is connected to the sampling system and the MCO port valve is open; the HEPA filter must be rated to operate at a minimum of $99.9 \%$ efficiency, as assumed in the safety analysis

- Sample hood exhaust flow indicating device - Provides positive indication that the sample hood exhaust system is operating and shows the air flow rate

- $\quad$ TSRs

- Perform a pressure-test of the port valve operator-MCO shield plug seal and of the sampling system pressure boundary within the sample hood up to and including the sampling line HEPA filter; the pressure test should ensure this pressure boundary integrity at the design pressure of the sampling system

- Verify that the air flow rate through the sampling hood is at least $100 \mathrm{ft}^{3} / \mathrm{min}$ just before opening the MCO port valve 
- Independent verification that the pressure test of the sampling system pressure boundary integrity was performed and demonstrated that the system is sufficiently leak-tight to proceed with the sampling operation

- Independent verification that the MCO port valve is properly closed prior to removal of the port valve operator from the MCO shield plug

A high-pressure gas cylinder is not expected to become a missile that could crash into the sample system and shear the piping because the gas cylinders used for MCO sampling and welding operations will be located outside the CSB. The only bottles available to create this hazard are those on the tube vent and purge cart and those brought into the facility for maintenance welding activities. Accidentally shearing the valve body from the cylinder, by dropping the cylinder or crashing something into the cylinder, would not result in the cylinder becoming a missile because the small orifice that remains in the neck of the bottle severely limits the flow rate of gas from the cylinder. Limiting the flow rate limits the thrust generated by the escaping gas such that the cylinder will not accelerate to a dangerous velocity. Removal of the flow-restricting orifice from a pressurized cylinder is an extremely difficult task that could not be accomplished by one person without special equipment. The following are the specific safety features and controls that prevent or mitigate this event:

- Safety-significant SSCs

- A flow-restricting orifice in the neck of gas cylinders - Limits the thrust produced by escaping gas to an amount that cannot accelerate the cylinder to dangerous velocity; this feature provides protection against accidental breaking-off of the valve body on top of the cylinder

- TSRs

- A TSR is not required; the Site and project maintenance programs will control maintenance involving gas cylinders, which will verify that the gas cylinders have orifice flow restrictors and will require cylinder suppliers to perform all maintenance.

3.6.2.2 Pressurized Release from Cask-Multi-Canister Overpack. An accident that involves dropping the loaded transportation cask while moving the transportation cask from the MCO transporter to the service pit is not considered a design basis accident because the transportation cask provides a structural barrier to protect against the release of radionuclides from the MCO that would make the consequences of this accident less severe than for the gaseous release from the MCO at the sampling/weld station provided that the drop height is less than $40 \mathrm{in}$. The following are the specific safety features and controls that prevent or mitigate this event:

- Safety-significant SSCs

- MCO shell, locking ring, and shield plug - Provide structural protection, containment, and confinement of SNF should the cask-MCO drop from the receiving crane 


\section{SNF-3328 REV 0}

- Transportation cask - Provide structural protection for the MCO

- Receiving crane lifting yoke (length) - Limits lift height of the bottom of the cask (maximum of $40 \mathrm{in}$.) above the floor when the cask-MCO is being lifted by the receiving crane

- TSRs

- Administrative control to verify use of the lifting yoke.

\subsection{REFERENCES}

DOE-HDBK-3010-94, 1994, Airborne Release Fractions/Rates and Respirable Fractions/Rates for Nonreactor Nuclear Facilities, U.S. Department of Energy, Washington, D.C.

HNF-3048, 1998, Post Fuel-Cleaning Corrosion of Uranium Within MCO Payloads, Rev. 0, Fluor Daniel Hanford, Incorporated, Richland, Washington.

HNF-SD-SNF-DP-010, 1997, Cask and MCO Drop onto the Transport Trailer Edge with Subsequent Horizontal Slap Down onto the CSB Receiving Area Floor, Rev. 0, Fluor Daniel Hanford, Incorporated, Richland, Washington.

HNF-SD-SNF-HIE-001, 1998, Canister Storage Building Hazard Analysis Report, Rev. 1, Draft, Fluor Daniel Hanford, Incorporated, Richland, Washington.

HNF-SD-SNF-TI-059, 1998, A Discussion on the Methodology for Calculating Radiological and Toxicological Consequences for the Spent Nuclear Fuel Project at the Hanford Site, Rev. 1, Fluor Daniel Hanford, Incorporated, Richland, Washington.

Petersen, S. L., 1998, Design Package for the Multi-Canister Overpacks Sampling Station (transmittal FDP-643, to M. K. Mahaffey, DE\&S Hanford, Incorporated, June 30), Rev. 0, Fluor Daniel Hanford, Incorporated, Richland, Washington.

Sellers, E. D., 1997, Risk Evaluation Guidelines (REGs) to Ensure Inherently Safer Designs (Letter 97-SFD-172 to H. J. Hatch, Fluor Daniel Hanford, Incorporated, August 26), U.S. Department of Energy, Richland Operations Office, Richland, Washington.

SNF-2770, 1998, Cold Vacuum Drying Facility Design Basis Accident Analysis Documentation, Rev. 0, Fluor Daniel Hanford, Incorporated, Richland, Washington. 
SNF-3328 REV 0

This page intentionally left blank. 
Figure 3-1. Logic Diagram for Canister Storage Building Pressurized Gaseous Release.

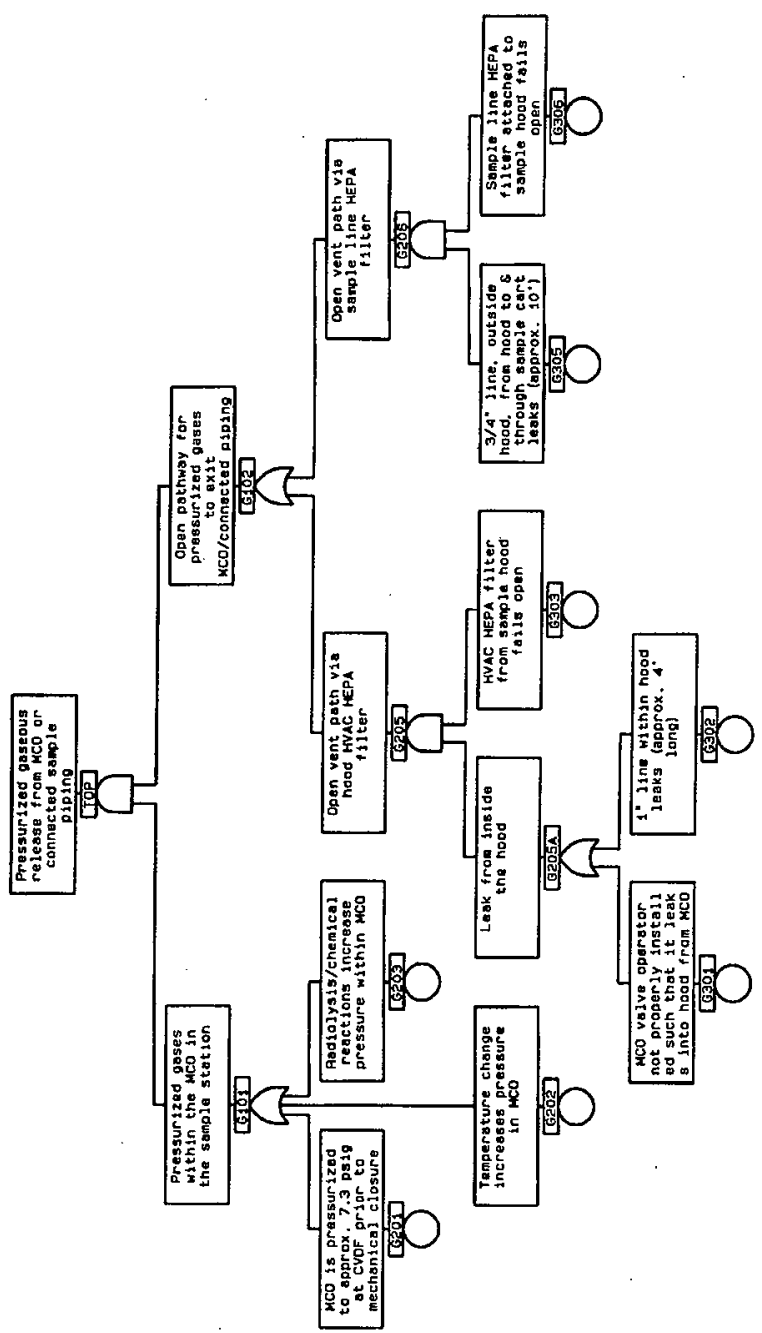


Figure 3-2. Gaseous Release at the Sampling/Weld Station and Mitigating Features.

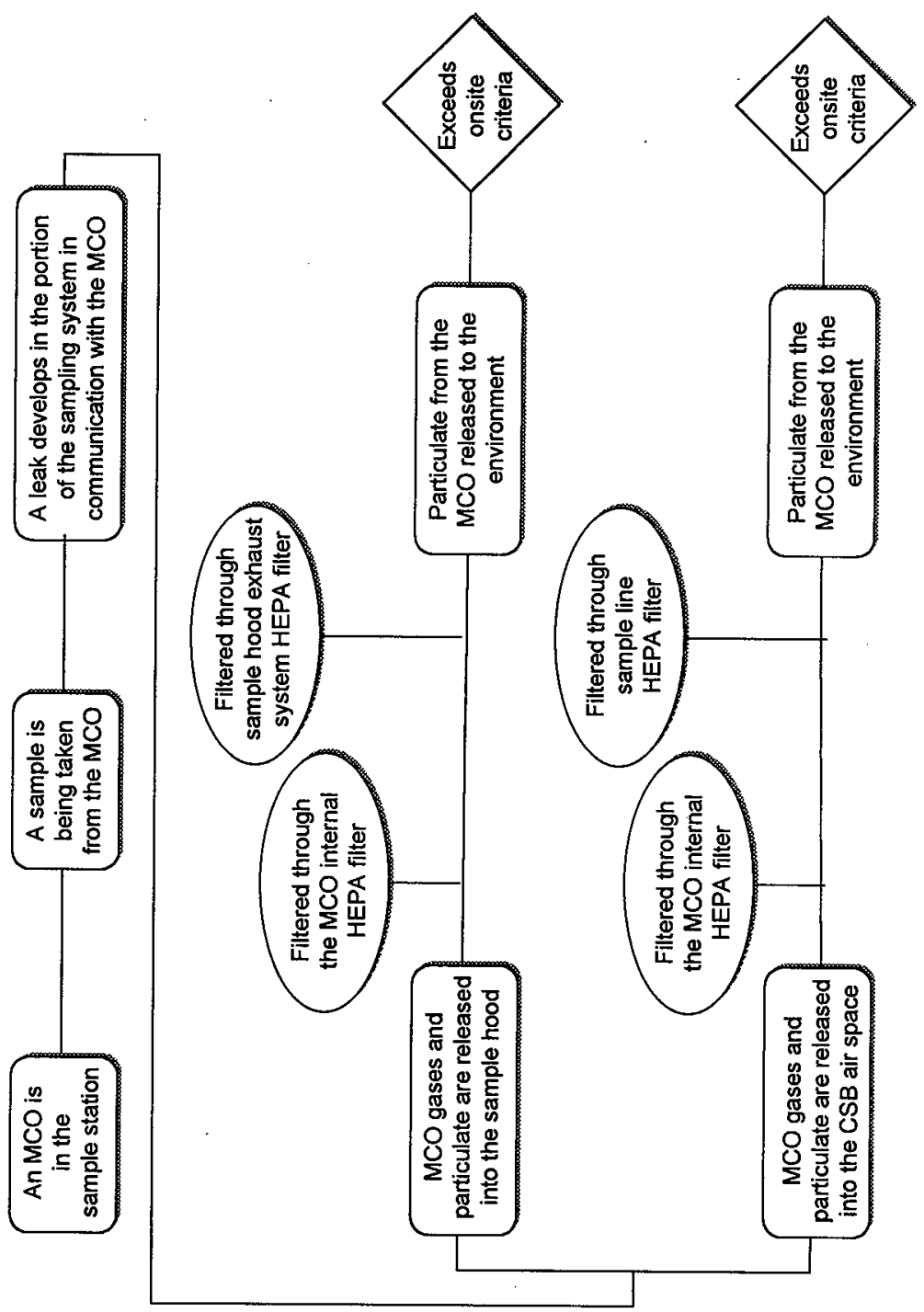




\subsection{CALCULATIONS FOR MULTI-CANISTER OVERPACK INTERNAL HYDROGEN EXPLOSION}

\subsection{PURPOSE AND OBJECTIVES}

Three events have been identified that could result in formation of flammable mixtures of hydrogen and oxygen inside a multi-canister overpack (MCO) while at the Canister Storage Building (CSB). These are described in Section 4.2. The first identified event is radiolytic decomposition of oxygen-containing compounds, such as aluminum hydroxide and uranium oxide (hydrate). The second event is the charging of an MCO with a gas containing oxygen at the sampling/weld station. The third event is an ingress of air to an MCO that has been breached at the CSB.

The accident event with bounding consequences is the explosion of a hydrogen-oxygen mixture at the sampling/weld station. This accident could exceed the temperature limits for the MCO sample hose and lead to its rupture and release of particulate to the air. The environmental release of radioactivity in this accident gives doses to individuals located downwind that exceed guidelines. Mitigation strategies are discussed in Section 4.5. Required controls are summarized in Section 4.6.

\subsection{SCENARIO DEVELOPMENT}

In the postulated accidents, hydrogen accumulates because of radiolytic decomposition or corrosion of uranium in a moist environment. The general sequence of events leading to a hydrogen explosion is shown in Figure 4-1. Two conditions necessary for radiolytic production of hydrogen and oxygen in the $\mathrm{MCO}$ are (1) enough aluminum hydroxide, uranium oxide (hydrated), or free water and (2) a high enough radiation level, which is indicated by the thermal power of the fuel. Two conditions necessary for production of hydrogen by reaction with uranium inside the $\mathrm{MCO}$ are adequate amounts of exposed uranium metal and water vapor.

Radiolytic production of hydrogen and oxygen occurs slowly, and the hydrogen is produced at several times the rate of the oxygen. Thus, the mixture is not combustible until the oxygen concentration exceeds the minimum necessary. Such events will not take place until near the end of the projected storage period.

Charging the MCO with oxygen at the sampling/weld station would occur early in the storage period because that is when sampling will take place. Note that hydrogen accumulates rather quickly inside the $\mathrm{MCO}$; the added oxygen creates a flammable mixture that could then explode. Because it takes very little energy to begin hydrogen-oxygen combustion, it has been assumed that ignition sources are present where needed. The specific accident scenarios evaluated are described in the following subsections. 


\section{SNF-3328 REV 0}

\subsubsection{Hydrogen Explosion During Storage due to Radiolysis}

Radiolytic decomposition of aluminum hydroxide, aluminum and iron hydrates, free water, and water bound as hydrates in the uranium oxide may lead to flammable mixtures of hydrogen and oxygen in an MCO. Hydrogen would be produced at a higher rate than the oxygen, making oxygen the limiting reactant. An explosion cannot occur until the oxygen concentration exceeds the minimum necessary.

Because oxygen gas reacts with uranium in damaged fuel elements, it is necessary to assume the active area of exposed uranium is zero. This is the minimum area assumption for safety basis calculations (HNF-SD-SNF-TI-017). With minimum exposed uranium, there is minimum hydrated water bound in the uranium oxides. Most of the oxygen comes from the aluminum hydroxide.

\subsubsection{Hydrogen Explosion Following Oxygen Addition at the Sampling/Weld Station}

At the sampling/weld station, the MCO is connected to the sample cart and a small gas sample is taken from the $\mathrm{MCO}$. If an $\mathrm{MCO}$ with the bounding hydrogen concentration were depressurized at this point, it would be necessary to recharge the MCO with helium. If required, inert gas is added to the MCO to raise the internal pressure to $4.0 \mathrm{lb} / \mathrm{in}^{2}$ gauge. Two methods for charging oxygen into the MCO have been postulated. One requires failing to purge air from the helium line so that air is forced into the MCO rather than helium. The other requires that the helium be contaminated with oxygen.

The helium line runs from the storage tank on the north side of the CSB to the sampling/weld station on the south side of the CSB. Due to its length, this pipe contains a large volume of air initially. It is possible for this line to be filled with air during a sampling sequence by omission of the helium purge steps.

Having a supply of helium contaminated with oxygen is possible because suppliers of compressed gases routinely prepare mixtures of helium and oxygen for medical use. Suppliers providing helium to the CSB will also be providing medical facilities with helium and oxygen mixtures.

By either method, oxygen is charged into an $\mathrm{MCO}$ with a bounding hydrogen concentration. The explosion is expected to occur shortly after the oxygen enters the MCO. Combustion temperatures and pressures are high enough that the hot gases forced from the MCO cause the sample line to melt. The compromise of the confinement boundary of the MCO leads to a release of particulate matter at the sampling/weld station. This scenario is diagramed in Figure 4-2. An event tree is provided in Appendix A. 


\subsubsection{Hydrogen Explosion Following an Air Ingress}

It is assumed that the MCO is breached. Gases inside the MCO can escape and gases outside the $\mathrm{MCO}$ can diffuse into the MCO. At some point there will be a flammable mixture in the MCO. The resulting explosion leads to a gaseous release of particulate matter.

\subsection{SOURCE TERM ANALYSIS}

The mathematical analysis of the postulated accidents focuses on the hydrogen and oxygen concentrations in an MCO. Mixtures of hydrogen in air are flammable in the range of $4 \%$ to $75 \%$ hydrogen by volume at atmospheric pressure. Very damaging shock waves may be produced if the hydrogen concentration is between 18 and 58 vol\% in air (NUREG/CR-2726). The stoichiometric ratio ( 2 moles hydrogen per 1 mole of oxygen) corresponds to $29.6 \%$ hydrogen in air. The presence of helium changes the stoichiometric ratio because it displaces oxygen. For example, if there are equal volume percents of hydrogen and helium, then the stoichiometric hydrogen concentration is reduced to $22.8 \%$. The minimum oxygen concentration needed for combustion is $4 \%$ (Bulletin 503). For a given oxygen and hydrogen concentration at higher initial gas pressures, the reaction is slowed by the increased amount of nonreacting atoms. The overall effect is to raise the minimum concentrations.

\subsubsection{Basis for Hydrogen Explosion due to Radiolysis}

The various assumptions used in this section are selected to show whether a combustible mixture of hydrogen and oxygen produced by radiolysis in the MCO is possible. These values should not be taken as limits.

Before leaving the Cold Vacuum Drying Facility (CVDF), the MCO is normally pressurized to about $152 \mathrm{kPa}\left(1.5 \mathrm{~atm}\right.$ or $\left.7.4 \mathrm{lb} / \mathrm{in}^{2}\right)$ with helium. To be conservative, the initial helium pressure is assumed to be $111.5 \mathrm{kPa}\left(1.5 \mathrm{lb} / \mathrm{in}^{2}\right.$ gauge). The average temperature of this helium is assumed to be $25^{\circ} \mathrm{C}\left(77^{\circ} \mathrm{F}\right)$. The initial helium inventory is computed using the ideal gas law as shown below. The normal helium inventory is 30.7 moles, while the low pressure assumption gives 22.5 moles helium.

$$
\mathrm{N}(\mathrm{He})=\left(\mathrm{P}_{\mathrm{MCO}}\right)\left(\mathrm{V}_{\mathrm{MCO}}\right) /(\mathrm{R}) /\left(\mathrm{T}_{\mathrm{gas}}\right)
$$

where

$$
\begin{aligned}
& \mathrm{N}(\mathrm{He})=\text { number of moles of helium in the MCO initially, } 30.7 \text { moles } \\
& \mathrm{P}_{\mathrm{MCO}}=\text { pressure of the helium in the MCO, } 1.5 \mathrm{~atm} \\
& \mathrm{~V}_{\mathrm{MCO}}=\text { volume of the } \mathrm{MCO}, 500 \mathrm{~L} \\
& \mathrm{R}=\text { ideal gas constant, } 0.082057 \mathrm{~L} \cdot \mathrm{atm} / \mathrm{mole} / \mathrm{K} \\
& \mathrm{T}_{\text {gas }} \quad=\text { temperature of the helium gas, } 298 \mathrm{~K}\left(25^{\circ} \mathrm{C}\right) .
\end{aligned}
$$


Oxygen and hydrogen are produced in the MCO by radiolysis of four materials: water, aluminum hydroxide, uranium oxide hydrate, and sludge hydrates. The principle reactions producing these gases are shown in Table 4-1. The oxygen is removed by reaction with exposed fuel to produce uranium oxide. This reaction is also shown in Table 4-1. The rate at which the production reactions take place depends on the radiation flux, the radiation interaction probability, and the radiolysis constants. The rate at which the removal reaction takes place depends primarily on the temperature of the fuel and its exposed area.

Table 4-1. Gas Production and Removal Reactions in the Multi-Canister Overpack.

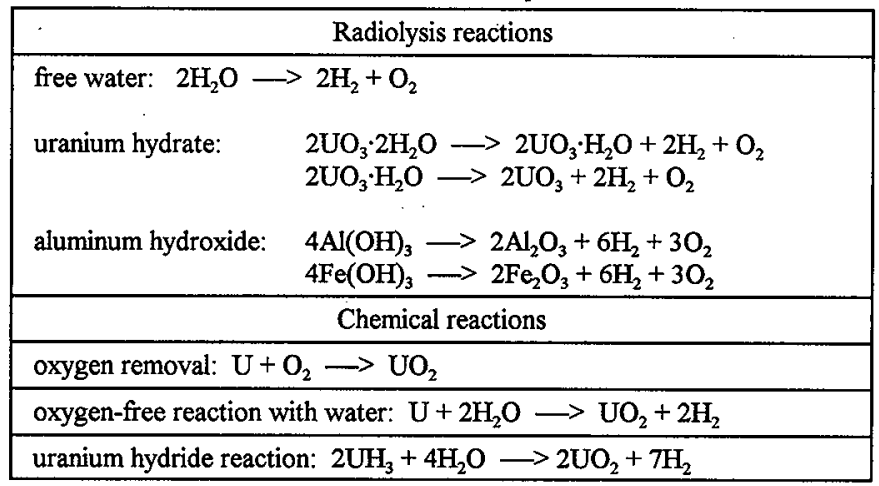

The radiation flux and the fuel temperature are proportional to the power level. To simplify matters and to be conservative, all of the energy associated with a particular radiation type is assumed to be absorbed in the MCO. Because the interaction of charged particles (e.g., alpha and beta radiation) is independent of the atomic number of the material, the relative amount of energy deposited in the various materials inside the MCO depends only on the relative mass of the material. For photon radiation, the interaction probability depends on the atomic number as well as the energy of the radiation. The relative amount of energy deposited in the various materials is the ratio of the products of the mass absorption coefficient times the mass of the material. These relationships are summarized in the following equation. The equation for oxygen production has the same form, except that radiolysis constants for oxygen are substituted.

$$
\mathrm{dN}_{\mathrm{X}}\left(\mathrm{H}_{2}\right) / \mathrm{dt}=(\mathrm{C})\left(\mathrm{M}_{\mathrm{X}} / \mathrm{M}_{\mathrm{U}}\right)(\mathrm{Q})\left\{\left(\mathrm{F}_{\mathrm{XU}}\right)\left[\left(\mathrm{F}_{\alpha}\right)\left(\mathrm{G}_{\mathrm{X}}^{\alpha}\left(\mathrm{H}_{2}\right)\right)+\left(\mathrm{F}_{\mathrm{B}}\right)\left(\mathrm{G}_{\mathrm{X}}^{\mathrm{s}}\left(\mathrm{H}_{2}\right)\right)\right]+\left(\mathrm{F}_{\mathrm{\Gamma}}\right)\left(\mathrm{G}_{\mathrm{X}}^{\Gamma}\left(\mathrm{H}_{2}\right)\right)\left(\mu_{\mathrm{X}} / \mu_{\mathrm{U}}\right)\right\}
$$

where

$$
\mathrm{dN}_{\mathrm{X}}\left(\mathrm{H}_{2}\right) / \mathrm{dt}=\text { rate of } \mathrm{H}_{2} \text { generation by radiolysis of material } \mathrm{X} \text {, mole/year }
$$




\section{SNF-3328 REV 0}

$$
\begin{aligned}
& \mathrm{C}=\text { conversion factor }=3.138(\text { mole })(100 \mathrm{eV}) /(\text { watt }) /(\text { year }) /(\text { molecule }) \\
& \mathrm{M}_{\mathrm{X}} / \mathrm{M}_{\mathrm{U}} \quad=\text { ratio of mass of material X in the MCO to the mass of uranium in the MCO } \\
& \mathrm{Q} \quad=\text { radiation power level in } \mathrm{MCO} \text {, watts } \\
& \mathrm{F}_{\mathrm{XU}} \quad=\text { fraction of material } \mathrm{X} \text { mass, which is uranium; it also represents a charged } \\
& \text { particle interaction fraction in material } \mathrm{X} \\
& \mathrm{F}_{\alpha} \quad=\text { fraction of } \mathrm{MCO} \text { power due to alpha radiation; modeled as an increasing } \\
& \text { exponential resulting from production by radioactive decay of other isotopes } \\
& \mathrm{G}_{\mathrm{X}}^{\alpha}\left(\mathrm{H}_{2}\right)=\text { radiolysis constant for } \mathrm{H}_{2} \text { generation in material } \mathrm{X} \text { by alpha radiation, } \\
& \text { molecules } \mathrm{H}_{2} \text { per } 100 \mathrm{eV} \text { deposited in material } \mathrm{X} \\
& \mathrm{F}_{\mathrm{B}} \quad=\text { fraction of } \mathrm{MCO} \text { power due to beta radiation; modeled as a decreasing } \\
& \text { exponential } \\
& \mathrm{G}_{\mathrm{X}}^{\mathrm{B}}\left(\mathrm{H}_{2}\right) \text { = radiolysis constant for } \mathrm{H}_{2} \text { generation in material } \mathrm{X} \text { by beta radiation, } \\
& \text { molecules } \mathrm{H}_{2} \text { per } 100 \mathrm{eV} \text { deposited in material } \mathrm{X} \\
& \mathrm{F}_{\Gamma} \quad=\text { fraction of } \mathrm{MCO} \text { power due to gamma radiation; modeled as a decreasing } \\
& \text { exponential } \\
& \mathrm{G}_{\mathrm{X}}^{\mathrm{T}}\left(\mathrm{H}_{2}\right)=\text { radiolysis constant for } \mathrm{H}_{2} \text { generation in material } \mathrm{X} \text { by gamma radiation, } \\
& \text { molecules } \mathrm{H}_{2} \text { per } 100 \mathrm{eV} \text { deposited in material X } \\
& \mu_{\mathrm{X}} / \mu_{\mathrm{U}} \quad=\text { ratio of the mass energy absorption coefficient for material } \mathrm{X} \text { to the } \\
& \text { coefficient for uranium. }
\end{aligned}
$$

Parameters used in the calculations are shown in Tables 4-2 and 4-3. The fractions of the total MCO thermal power for each radiation type are derived from the 1995 and 2040 power levels and the assumed formulas shown in Table 4-2. Note that fuel drying does not happen until the year 2000 , or 2 years after the current dates for bounding power levels given in HNF-SD-SNF-TI-015, Spent Nuclear Fuel Project Technical Databook. These power fractions are plotted in Figure 4-3. The formulas for beta and gamma radiation shown on Table 4-2 are from HNF-SD-SNF-TI-040, MCO Internal Gas Composition and Pressure During Interim Storage. The formula for alpha radiation is different but represents the increase in power fraction more accurately.

The masses shown on Table 4-3 are taken from HNF-SD-SNF-TI-015. The exposed uranium fuel surface area also is assumed to determine the amount of uranium hydrate and free water present. The bounding case MCO with no scrap baskets has intact fuel. The exposed area is zero; thus, the free water inventory is zero. There is a small amount of uranium oxide 
Table 4-2. Parameters to Model the Decreasing Multi-Canister Overpack Power Level.

\begin{tabular}{|l|c|c|c|}
\hline \multicolumn{1}{|c|}{ Parameter } & Alpha radiation & Beta radiation & Gamma radiation \\
\hline Scale factor, $S F$ & 0.2447 & 0.4862 & 0.3171 \\
\hline Half life & $14.3 \mathrm{y}$ & $28.8 \mathrm{y}$ & $28.7 \mathrm{y}$ \\
\hline Decay constant, $\mathrm{L}$ & $0.0486 \mathrm{y}^{-1}$ & $0.0241 \mathrm{y}^{-1}$ & $0.0242 \mathrm{y}^{-1}$ \\
\hline Time offset, $\mathrm{T}_{\mathbf{0}}$ & $33.5 \mathrm{y}$ & NA & NA \\
\hline
\end{tabular}

If " $\mathrm{t}$ " is the elapsed time (years since 1995), then the fractions of total power contributed by each type of radiation are listed below:

alpha radiation: $\quad F_{\alpha}=\left(\mathrm{SF}_{\alpha}\right)\left\{1.00-\operatorname{Exp}\left[-\left(\mathrm{L}_{\alpha}\right)\left(\mathrm{t}+\mathrm{t}_{0}\right)\right]\right\}$

beta radiation: $\quad F_{B}=\left(\mathrm{SF}_{\mathrm{B}}\right) \operatorname{Exp}\left[-\left(\mathrm{L}_{\mathrm{B}}\right)(\mathrm{t})\right]$

gamma radiation: $\left.F_{r}=\left(S_{T}\right) \operatorname{Exp}\left[-I_{r}\right)(t)\right]$.

NA $=$ not applicable.

Table 4-3. Parameters for Calculating the Rate of Hydrogen and

Oxygen Generation Within a Multi-Canister Overpack.

\begin{tabular}{|c|c|c|c|c|c|}
\hline Parameter & $\mathrm{H}_{2} \mathrm{O}$, free & $\mathrm{UO}_{3} \cdot 2 \mathrm{H}_{2} \mathrm{O}$ & $\mathrm{UO}_{3} \cdot \mathrm{H}_{2} \mathrm{O}$ & $\mathrm{Al}(\mathrm{OH})_{3}$ & $\begin{array}{c}\text { Al \& Fe } \\
\text { hydrate }\end{array}$ \\
\hline $\mathrm{M}_{\mathrm{X}}$ & $200 \mathrm{~g}$ & $320 \mathrm{~g}$ & 0 & $10,650 \mathrm{~g}$ & $1,280 \mathrm{~g}$ \\
\hline $\mathrm{G}_{\mathrm{X}}^{\alpha}\left(\mathrm{H}_{2}\right)$ & 1.5 & 0.168 & 0.089 & 0.520 & 0.260 \\
\hline $\mathrm{G}_{\mathrm{X}}^{\mathrm{R}}\left(\mathrm{H}_{2}\right)$ & 0.45 & 0.050 & 0.027 & 0.156 & 0.078 \\
\hline $\mathrm{G}_{\mathrm{X}}^{\Gamma}\left(\mathrm{H}_{2}\right)$ & 0.45 & 1.2 & 1.2 & 1.2 & 1.2 \\
\hline$\mu_{\mathrm{X}}, \mathrm{cm}^{2} / \mathrm{g}$ & 0.03264 & 0.06534 & 0.06727 & 0.03015 & 0.02982 \\
\hline$\mu_{\mathrm{X}} / \mu_{\mathrm{U}}$ & 0.421 & 0.843 & 0.868 & 0.389 & 0.385 \\
\hline $\mathrm{G}_{\mathrm{X}}^{\alpha}\left(\mathrm{O}_{2}\right)$ & 0.75 & 0.084 & 0.044 & 0.260 & 0.130 \\
\hline $\mathrm{G}_{\mathrm{X}}^{\mathrm{B}}\left(\mathrm{O}_{2}\right)$ & 0.225 & 0.025 & 0.013 & 0.078 & 0.039 \\
\hline $\mathrm{G}_{\mathrm{X}}^{\Gamma}\left(\mathrm{O}_{2}\right)$ & 0.225 & 0.102 & 0.059 & 0.134 & 0.110 \\
\hline Molecular wt & $18 \mathrm{~g} / \mathrm{mole}$ & $322 \mathrm{~g} / \mathrm{mole}$ & $304 \mathrm{~g} / \mathrm{mole}$ & $78 \mathrm{~g} / \mathrm{mole}$ & $92.5 \mathrm{~g} / \mathrm{mole}$ \\
\hline $\mathrm{F}_{\mathrm{XU}}$ & 1.0 & 0.739 & 0.783 & 0 & 0.011 \\
\hline
\end{tabular}

Notes: The total mass of uranium in the MCO is taken as $6,339.6 \mathrm{~kg}$. The units for " $\mathrm{G}^{\prime \prime}$ values are molecules per $100 \mathrm{eV}$ deposited. Values for " $\mathrm{G}$ " are from HNF-SD-SNF-TI-015, 1998, Spent Nuclear Fuel Project Technical Databook, Rev. 6, Fluor Daniel Hanford, Incorporated, Richland, Washington. Mass absorption coefficient ratios are at an energy of $662 \mathrm{keV}$, which is the principle component of the gamma spectrum. The mass absorption coefficient are from ANSI/ANS-6.4.3, 1991, Gamma-Ray Attenuation Coefficients and Buildup Factors for Engineering

Materials, American National Standards Institute, New York, New York. For uranium the value is $0.07753 \mathrm{~cm}^{2} / \mathrm{g}$.

$\mathrm{MCO}=$ multi-canister overpack. 
associated with the sludge that does not become zero. With no scrap baskets, the uranium oxide amount is $320 \mathrm{~g}$.

The radiolysis constants are taken from HNF-SD-SNF-TI-015. For gamma radiation the hydrogen and oxygen constants are stoichiometric (i.e., 2 to 1). However, for the other materials, the hydrogen production is more than 10 times the oxygen production. This difference is not well explained; it appears to be a combination of oxygen entrapment and hydrogen over-estimation.

The values for the mass absorption coefficients shown on Table 4-3 are taken from ANSI/ANS-6.4.3, Gamma-Ray Attentuation Coefficients and Buildup Factors for Engineering Materials. The values chosen are at the dominant energy of the photon spectrum, $662 \mathrm{keV}$, characteristic of Cs-137 and Ba- $137 \mathrm{~m}$. The ratios of mass absorption coefficients are used in the calculations. The values shown were computed from a fifth order interpolating polynomial using three table values of higher and lower energies.

Values for $F_{x i}$ indicate the fraction of alpha and beta energy that may affect the material. For the uranium oxides, the value is the mole ratio of uranium and the compound. Water is assumed to be located in cracks and crevices, so the interaction fraction is 1.0. For aluminum hydroxide the interaction fraction is zero because the aluminum hydroxide is located on the cladding. For the canister particulate, the average interaction fraction is the mass of uranium divided by the mass of the canister particulate, that is $(236.5 \mathrm{~g} \mathrm{U}) /(1,600 \mathrm{~g})=0.148$. Because the canister particulate is $20 \%$ uranium oxide dihydrate, the interaction fraction can also be computed from the $\mathrm{UO}_{3} \cdot 2 \mathrm{H}_{2} \mathrm{O}$ fraction as $(0.20)(0.739)=0.148$.

For comparison with calculations presented in HNF-SD-SNF-TI-040, the fractions of hydrate and hydroxide removed by radiolysis were computed. These are shown on Table 4-4. The first two rows of fractions differ due to different values for radiolysis constants and mass absorption coefficients. In addition, there are slightly different power levels, because the present calculations have two years of decay prior to the onset of radiolysis. This reduces the removal fractions as shown in Table 4-4.

Figure 4-4 shows the production of oxygen for all radiation types in each target material for no scrap baskets and intact fuel. It is assumed that the MCO is processed in the year 2000, which means that the power level has been decreasing for 2 years. Hence, the time scale begins at 2 years and ends at 42 years, corresponding to the years 2000 to 2040 . The MCO is assumed to have a thermal power level of $776 \mathrm{~W}$. There are no oxygen removal mechanisms in effect so that the relative importance of the various materials can be observed. The aluminum hydroxide contributes nearly all of the oxygen. The assumed effect of radiation on uranium dihydrate is to free one of the water molecules leaving uranium monohydrate. The uranium monohydrate in turn loses its water, but at a slower rate. The contribution of free water is included for information. With intact fuel, the assumed free water is zero. 
Table 4-4. Radiolysis Removal Fractions.

\begin{tabular}{|c|c|c|c|c|}
\hline Conditions & $\begin{array}{c}\text { Free water } \\
(\%)\end{array}$ & $\begin{array}{c}\mathrm{UO}_{3} \cdot 2 \mathrm{H}_{2} \mathrm{O} \\
(\%)\end{array}$ & $\begin{array}{c}\mathrm{Al}(\mathrm{OH})_{3} \\
(\%)\end{array}$ & $\begin{array}{c}\mathrm{Al} \& \mathrm{Fe} \text { hydrates } \\
(\%)\end{array}$ \\
\hline $\begin{array}{c}\text { HNF-SD-SNF-TI-040 } \\
396 \mathrm{~W} ; 40 \mathrm{y}\end{array}$ & 7.0 & 50 & 3.6 & Not given \\
\hline $\begin{array}{c}\text { Present work } \\
396 \mathrm{~W} ; 40 \mathrm{y}\end{array}$ & 6.9 & 45 & 3.6 & 4.8 \\
\hline $\begin{array}{c}\text { Present work } \\
776 \mathrm{~W} ; 40 \mathrm{y}\end{array}$ & 13 & 69 & 7.0 & 9.2 \\
\hline $\begin{array}{c}\text { Present work } \\
776 \mathrm{~W} ; \mathrm{y}\end{array}$ & 0.39 & 4.2 & 0.28 & 0.36 \\
\hline
\end{tabular}

The percentages are the fractions of the materiais shown that are decomposed by radiolysis. These fractions are independent of the initial inventory of the material.

HNF-SD-SNF-TI-040, 1998, MCO Internal Gas Composition and Pressure During Interim Storage, Rev. 2, Fluor Daniel Hanford, Incorporated, Richland, Washington.

Figure 4-5 shows the production of hydrogen for all radiation types in each target material based on the same parameters used for Figure 4-4. As with the oxygen, most of the hydrogen comes from aluminum hydroxide. Both figures include the gas production from free water even though the assumption of intact fuel means no free water.

Oxygen reacts readily with any exposed fuel to form uranium oxide as shown in Table 4-1. This lowers the oxygen concentration in the MCO. The reaction rate depends on the temperature of the fuel and the area of exposed fuel. The fuel temperature can be estimated using the method described in HNF-SD-SNF-TI-040. The equation for this is shown below. Values for the correlation constant are developed in Appendix A of HNF-SD-SNF-TI-040. The value recommended for fuel is $\mathrm{Cw}=9.5 \mathrm{~W} / \mathrm{K}$.

$$
\begin{gathered}
\mathrm{T}_{\text {fuel }}=(\mathrm{W}) /(\mathrm{CW})+\mathrm{T}_{\text {amb }} \\
\mathrm{T}_{\mathrm{gas}}=(0.75)(\mathrm{W}) /(\mathrm{CW})+\mathrm{T}_{\text {amb }}
\end{gathered}
$$

where

$\mathrm{T}_{\text {fuel }}=$ temperature of the fuel, in degrees kelvin

$\mathrm{T}_{\text {gas }}=$ temperature of the $\mathrm{MCO}$ gas, in degrees kelvin

$\mathrm{W}=$ total power of the $\mathrm{MCO}$, in watts

$\mathrm{Cw}=$ correlation constant, 9.5 watts per degree kelvin

$\mathrm{T}_{\mathrm{amb}}=$ annual average ambient temperature, $285 \mathrm{~K}\left(12{ }^{\circ} \mathrm{C}\right)$. 


\section{SNF-3328 REV 0}

The temperature of the MCO gas is assumed to be $75 \%$ of the difference with the ambient temperature. This temperature is needed to estimate the pressure of the gas in the MCO.

With large surface areas, the oxygen removal rate is large enough that the oxygen concentration is greatly reduced. When the oxygen concentration falls below $10 \mathrm{vppm}(0.001 \%)$ then the oxygen-free reaction between fuel and water vapor proceeds. The formula for this reaction is shown in Table 4-1. To maximize the concentration of oxygen, the exposed fuel surface is reduced to the safety basis minimum, namely, $0 \mathrm{~m}^{2}$. The only oxygen-producing materials are aluminum hydroxide and sludge (canister particulate).

Figure 4-6 shows the total hydrogen and oxygen concentrations and the pressure inside the MCO as a function of time after leaving the CVDF. The initial MCO pressure upon leaving the CVDF is $1.1 \mathrm{~atm}$. The MCO gas is entirely helium at the time it is sealed at the CVDF. Using the bounding inventories for free water and aluminum hydroxide, the oxygen concentration exceeds the minimum needed to support combustion (4.0\%).

By the year 2040, the hydrogen concentration has reached $40.5 \%$ and the oxygen concentration has reached $4.7 \%$. The MCO pressure at this time is $225 \mathrm{kPa}$ (2.22 atm or $18.0 \mathrm{lb} / \mathrm{in}^{2}$ gauge). The $\mathrm{MCO}$ gas temperature is $318 \mathrm{~K}\left(45^{\circ} \mathrm{C}\right)$. The assumed power level is $776 \mathrm{~W}$. Note that for fuel coated in aluminum hydroxide, the maximum power level is $527 \mathrm{~W}$ (HNF-3035). At this lower power level, the peak oxygen concentration is $3.9 \%$ at a pressure of $186 \mathrm{kPa}\left(1.83 \mathrm{~atm}\right.$ or $\left.12 \mathrm{lb} / \mathrm{in}^{2}\right)$.

From the curves for hydrogen and oxygen, it is evident that these gases are not liberated in stoichiometric proportions. The ratio of hydrogen to oxygen is about 7 to 1 , rather than the stoichiometric ratio of 2 to 1 . It is assumed that most of the generated oxygen is held in the corrosion layer so that only hydrogen is free to accumulate. If this assumption is not true, then MCO pressures and hydrogen concentrations would be higher.

\subsubsection{Basis for a Fydrogen Explosion due to Oxygen in the Helium System}

The composition of the gas inside the MCO shortly after it arrives at the CSB is assumed to be only helium and hydrogen. The hydrogen is generated primarily by reaction between exposed fuel and water vapor. The radiolytic decomposition of water and hydroxides adds very little and is not considered. For a reaction to occur rapidly, there must be a large, exposed fuel surface area. The MCO with two scrap baskets is bounding.

The bounding hydrogen content of an MCO with two scrap baskets will be estimated assuming the water reactions with uranium metal and uranium hydride occur at the same rate. From HNF-SD-SNF-TI-015, Spent Nuclear Fuel Project Technical Databook, the enhancement factor for the metal reaction is 10 while the enhancement factor for the hydride reaction is 12 . In addition, the metal reaction produces 1 mole of hydrogen gas for every mole of water reacted; but the hydride reaction produces 1.75 moles hydrogen for every mole of water reacted. The combined effect is that the hydrogen generation increases by the factor 


$$
\frac{(10)(1)+(12)(1.75)}{10+12}=1.409
$$

over the amount expected from the uranium metal reaction alone.

The hydrogen gas that could be generated from the uranium metal is limited by the amount of water available to react. The bounding free water estimate is $200 \mathrm{~g}$ in crevices and cracks. In addition, uranium oxide dihydrate will lose one of the water molecules at normal $\mathrm{MCO}$ temperatures (HNF-1523). Much of this loss may occur during drying at CVDF, but to maximize the hydrogen generation after drying none will be assumed. The bounding hydrated water estimate for 2 scrap baskets is $1,190 \mathrm{~g}$ water. Half of this amount is available to react with uranium fuel to form hydrogen. The total water mass of $795 \mathrm{~g}$ is equivalent to 44 moles of water. The hydride enhancement described above leads to the bounding production of 62 moles of hydrogen in the MCO. From the ideal gas law, this hydrogen has a volume of $1,520 \mathrm{~L}$ at reference conditions.

The initial low helium inventory is 22.5 moles (see Section 4.3.1). Thus, the gas in the MCO is $27 \%$ helium and $73 \%$ hydrogen. Chapter 5.0 shows that the reaction producing this hydrogen can proceed rather quickly, so that by the time an $\mathrm{MCO}$ is sampled it is reasonable to assume the above hydrogen inventory has been realized.

An MCO containing the bounding hydrogen gas inventory is vented at the sampling/weld station and assumed to be completely depressurized so that recharge with helium is necessary. However, instead of charging the MCO with helium, a gas mixture containing oxygen is added and creates a flammable mixture of hydrogen and oxygen in the MCO.

When the MCO is depressurized, the relative amounts of helium and hydrogen remain unchanged. The gas mixture is still $27 \%$ helium and $73 \%$ hydrogen. At a pressure of $1 \mathrm{~atm}$ and a temperature of $50^{\circ} \mathrm{C}\left(122^{\circ} \mathrm{F}\right)$, the $\mathrm{MCO}$ inventory is 18.9 moles total, or 13.9 moles hydrogen and 5.0 moles helium.

The action of adding a helium and oxygen mixture to the $\mathrm{MCO}$ increases the pressure in the MCO to $129 \mathrm{kPa}$ ( $1.27 \mathrm{~atm}$ or $4.0 \mathrm{lb} / \mathrm{in}^{2}$ gauge). The amount of gas added is calculated from the ideal gas law to be 5.1 moles. The final total in the MCO is 24.0 moles. The hydrogen concentration decreases from $73 \%$ to $58 \%$. The oxygen concentration in the MCO depends on the oxygen concentration in the added gas. From the ideal gas law, the oxygen concentration in the MCO follows the absolute pressures. Thus, the final oxygen concentration is $0.27 / 1.27=$ 0.213 times the concentration of the added gas. If the added gas were $60 \%$ oxygen, then the oxygen concentration in the MCO would be $12.8 \%$.

To achieve a flammable mixture at atmospheric pressure, the oxygen concentration must exceed $4.9 \%$ in the MCO. Thus, the oxygen concentration of the added gas must be greater than $23 \%$. Note the oxygen concentration in air is $21 \%$. To achieve a mixture in the MCO that will produce very damaging shock waves, the oxygen concentration in the MCO must be at least $9 \%$. 
Thus, the flammable mixture in the MCO does not become very damaging until the oxygen concentration in the added gas exceeds $42 \%$.

\subsubsection{Basis for Hydrogen Explosion After an Air Ingress}

Due to an accident that breaches the MCO, the gases inside the MCO rush out. While recovery plans are being made, air diffuses into the $\mathrm{MCO}$ and the gas inside diffuses out. At some point, a flammable mixture is reached.

As discussed in Section 4.3.2, the low helium MCO contains a mixture of $73 \%$ hydrogen and $27 \%$ helium. When this mixes with air containing $21 \%$ oxygen and $79 \%$ nitrogen, the stoichiometric mixture of hydrogen and oxygen is reached after about $67 \%$ of the gas in the MCO has been replaced with air. The final mixture is $5 \%$ helium, $28 \%$ hydrogen, $14 \%$ oxygen, and $53 \%$ nitrogen. These determine the peak pressure during combustion.

\subsubsection{Method to Estimate Peak Pressures due to Hydrogen Combustion}

When the hydrogen and oxygen react, water vapor is formed and energy is released. To be conservative, it is assumed that the energy released stays in the gas and none is lost to the MCO components. The heat capacity of the gases allows the final temperature to be computed. This final temperature, together with the number of moles of gases in the MCO and the ideal gas law, is used to calculate the final pressure due to the combustion.

The heat of water vapor formation from hydrogen and oxygen gas is $57,800 \mathrm{cal} / \mathrm{mole}$ at a temperature of about $300 \mathrm{~K}\left(27^{\circ} \mathrm{C}\right)$. The heat capacity of various gases is calculated from a quadratic formula as listed in Table 4-5.

Table 4-5. Parameters to Determine Heat Capacities.

\begin{tabular}{|c|c|c|c|}
\hline Gas & A & B & C \\
\hline $\mathrm{H}_{2}$ & 4.959 & $-1.96 \mathrm{E}-04$ & $4.76 \mathrm{E}-07$ \\
\hline $\mathrm{N}_{2}$ & 4.470 & $1.39 \mathrm{E}-03$ & $-6.90 \mathrm{E}-08$ \\
\hline $\mathrm{O}_{2}$ & 4.130 & $3.17 \mathrm{E}-03$ & $-1.01 \mathrm{E}-06$ \\
\hline $\mathrm{H}_{2} \mathrm{O}$ & 5.149 & $2.64 \mathrm{E}-03$ & $4.59 \mathrm{E}-08$ \\
\hline $\mathrm{He}$ & 3.020 & 0 & 0 \\
\hline
\end{tabular}

Notes: The heat capacity at constant volume (in cal/mole/K) is computed from the formula $\mathrm{Cv}=$ $\mathrm{A}+\mathrm{B} \cdot \mathrm{T}+\mathrm{C} \cdot \mathrm{T}^{2}$, where $\mathrm{T}$ is the temperature of the gas. The heat capacities apply to the temperature range from $300 \mathrm{~K}\left(27^{\circ} \mathrm{C}\right)$ to $1,500 \mathrm{~K}\left(1,227^{\circ} \mathrm{C}\right)$. At higher temperatures the heat capacities are over-estimated. 


\section{SNF-3328 REV 0}

The final temperature of the gas mixture is found using the following formula. The integration is between the initial temperature of the gas mixture before combustion and the final temperature of the gas mixture after combustion. The summation is over the types of gases present in the $\mathrm{MCO}$ after combustion. Because the final gas temperature is unknown but determines the heat capacities, the temperature must be solved by an iterative process.

$$
\left(\mathrm{H}_{\mathrm{F}}\right)\left(\mathrm{N}_{\mathrm{H} 2 \mathrm{O}}\right)=\int_{\mathrm{T}_{\mathrm{o}}}^{\mathrm{T}_{\mathrm{f}}}\left(\sum(\mathrm{Cvi})(\mathrm{Ni})\right)
$$

where

$\mathrm{H}_{\mathrm{F}}=$ heat of formation of water from hydrogen and oxygen, 57,800 calories per mole formed as a vapor

$\mathrm{N}_{\mathrm{H} 2 \mathrm{O}}=$ number of moles of water formed; computed as the smaller of the number of moles of hydrogen and twice the number of moles of oxygen (prior to combustion)

$\mathrm{T}_{0}=$ temperature of the gas mixture before combustion, in Kelvin

$\mathrm{T}_{\mathrm{f}}=$ temperature of the gas mixture after combustion, in Kelvin

Cvi = heat capacity at constant volume of gas "I"; depends on the temperature of the gas (represented as a quadratic equation)

$\mathrm{Ni}=$ number of moles of gas "I" after the oxygen and hydrogen react.

For an explosion near the end of the projected storage period, the gas in the MCO is made of 22.5 moles helium, 17.3 moles hydrogen, 2.0 moles oxygen, and 0.9 mole water vapor. The MCO pressure at this time is $225 \mathrm{kPa}$ (2.22 atm or $18 \mathrm{lb} / \mathrm{in}^{2}$ gauge). The MCO gas temperature is $318 \mathrm{~K}\left(45^{\circ} \mathrm{C}\right)$.

Because the oxygen concentration exceeds the minimum needed for combustion (4.9\%), the combustion temperature and pressure will be computed. The combustion reaction uses all 2.0 moles of oxygen, together with 4.0 moles of hydrogen. This produces an additional 4.0 moles of water vapor. The final gas mixture in the MCO is 22.5 moles helium, 13.3 moles hydrogen, and 4.9 moles water vapor. The energy liberated by the formation of the water vapor is 233,000 calories.

By an iterative process, the final temperature of the gas mixture is calculated to be $1,640 \mathrm{~K}$ $\left(1,370^{\circ} \mathrm{C}\right)$. The corresponding pressure in the $\mathrm{MCO}$ is $1,110 \mathrm{kPa}\left(11.0 \mathrm{~atm}\right.$ or $146 \mathrm{lb} / \mathrm{in}^{2}$ gauge). Because the welded MCO is designed to withstand internal pressures of $450 \mathrm{lb} / \mathrm{in}^{2}$, the $\mathrm{MCO}$ is 


\section{SNF-3328 REV 0}

not damaged by this pressure. The energy liberated is absorbed in the MCO contents and walls, which increases their temperature.

The above radiolysis model was used to estimate bounding aluminum hydroxide and water inventories that would have combustion pressures greater than the MCO design pressure of $450 \mathrm{lb} / \mathrm{in}^{2}$ gauge. The maximum thermal power level of $776 \mathrm{~W}$ was assumed. With a helium fill pressure of $1.1 \mathrm{~atm}$, the MCO must have $48 \mathrm{~kg}$ of $\mathrm{Al}(\mathrm{OH})_{3}$ present.

With less hydrogen in the $\mathrm{MCO}$, the oxygen concentration is increased. The hydrogen might be reduced by lower radiolysis constants (values shown in Table 4-3 were bounding) or by hydrogen gettering (reaction between hydrogen and bare metal to form metal hydrides). The combustion temperatures and pressures would be affected by such a change in concentration. Several cases were run using an MCO inventory of 22.5 gmoles helium and 2.0 gmoles oxygen. Results are shown in Table 4-6. As the hydrogen inventory increases past stoichiometric (i.e., 4.0 gmoles hydrogen), the combustion energy remains constant. However, the combustion temperature declines due to the increased mass of gas in the $\mathrm{MCO}$. The mass and temperature effects offset one another so that the combustion pressure in the MCO hardly changes with hydrogen inventory. Thus, if higher concentrations of oxygen are present due to decreases in hydrogen, there is no appreciable effect on the combustion pressure.

For an explosion at the sampling/weld station due to air in the helium line, the gas added to the $\mathrm{MCO}$ is $21 \%$ oxygen and $79 \%$ nitrogen. The composition of the gas before combustion is 5.0 gmoles helium, 13.9 gmoles hydrogen, 1.1 gmoles oxygen, and 4.0 gmoles nitrogen. The MCO pressure is $129 \mathrm{kPa}\left(1.27\right.$ atm or $\left.4.0 \mathrm{lb} / \mathrm{in}^{2}\right)$. The $\mathrm{MCO}$ gas temperature is $323 \mathrm{~K}\left(50^{\circ} \mathrm{C}\right)$.

The combustion reaction uses 1.1 gmoles oxygen together with 2.2 gmoles hydrogen. This produces 2.2 gmoles water vapor. The final gas mixture in the MCO is 5.0 gmoles helium, 11.7 gmoles hydrogen, 2.2 gmoles water vapor, and 4.0 gmoles nitrogen. The energy liberated by the formation of the water vapor is 124,000 calories.

By an iterative process, the final temperature of the gas mixture is $1408 \mathrm{~K}\left(1134^{\circ} \mathrm{C}\right)$. The corresponding pressure in the MCO is $536 \mathrm{kPa}$ (5.29 atm or $63 \mathrm{lb} / \mathrm{in}^{2}$ gauge). This is well below the MCO design pressure of $450 \mathrm{lb} / \mathrm{in}^{2}$. In addition, the sample line and connection are designed to withstand even greater pressure. However, the sample line is vulnerable to high temperatures. When the explosion occurs, the sample line can melt to the point that gases in the MCO rush out carrying particulate matter into the environment.

For an explosion at the sampling/weld station due to impure helium, if the gas added to the $\mathrm{MCO}$ is $60 \%$ oxygen, then the composition of the MCO gas before combustion is 7.1 moles helium, 13.9 moles hydrogen, and 3.0 moles oxygen. The MCO pressure at this time is $129 \mathrm{kPa}$ (1.27 atm or $4.0 \mathrm{lb} / \mathrm{in}^{2}$ gauge). The MCO gas temperature is $323 \mathrm{~K}\left(50^{\circ} \mathrm{C}\right)$. 
Table 4-6. Effect of Hydrogen Inventory in the Multi-Canister Overpack on Combustion Pressures.

\begin{tabular}{|c|c|c|c|c|c|c|}
\hline \multirow{2}{*}{$\begin{array}{c}\text { Hydrogen } \\
\text { (gmoles) }\end{array}$} & \multirow{2}{*}{$\begin{array}{c}\text { Total } \\
\text { (gmoles) }\end{array}$} & \multicolumn{2}{|c|}{ Gas concentration } & \multirow{2}{*}{$\begin{array}{c}\mathrm{MCO} \\
\text { pressure } \\
\text { (atm) }\end{array}$} & \multicolumn{2}{|c|}{ Combustion results } \\
\hline & & $\mathrm{H}_{2}$ & $\mathrm{O}_{2}$ & & $\begin{array}{c}\text { Temperature } \\
(\mathrm{K})\end{array}$ & $\begin{array}{c}\text { Pressure } \\
\text { (atm) }\end{array}$ \\
\hline 2 & 26.5 & $7.55 \%$ & $7.55 \%$ & 1.41 & 1,335 & 7.45 \\
\hline 3 & 27.5 & $10.91 \%$ & $7.27 \%$ & 1.46 & 1,762 & 9.98 \\
\hline 4 & 28.5 & $14.04 \%$ & $7.02 \%$ & 1.51 & 2,138 & 12.28 \\
\hline 5 & 29.5 & $16.95 \%$ & $6.78 \%$ & 1.56 & 2,067 & 12.21 \\
\hline 6 & 30.5 & $19.67 \%$ & $6.56 \%$ & 1.62 & 2,003 & 12.16 \\
\hline 8 & 32.5 & $24.62 \%$ & $6.15 \%$ & 1.72 & 1,888 & 12.09 \\
\hline 10 & 34.5 & $28.99 \%$ & $5.80 \%$ & 1.83 & 1,789 & 12.04 \\
\hline 12 & 36.5 & $32.88 \%$ & $5.48 \%$ & 1.94 & 1,703 & 12.02 \\
\hline 16 & 40.5 & $39.51 \%$ & $4.94 \%$ & 2.15 & 1,558 & 12.02 \\
\hline 20 & 44.5 & $44.94 \%$ & $4.49 \%$ & 2.36 & 1,441 & 12.06 \\
\hline 24 & 48.5 & $49.48 \%$ & $4.12 \%$ & 2.57 & 1,345 & 12.14 \\
\hline 28 & 52.5 & $53.33 \%$ & $3.81 \%$ & 2.78 & 1,264 & 12.24 \\
\hline 32 & 56.5 & $56.64 \%$ & $3.54 \%$ & 3.00 & 1,195 & 12.35 \\
\hline 36 & 60.5 & $59.50 \%$ & $3.31 \%$ & 3.21 & 1,135 & 12.48 \\
\hline 40 & 64.5 & $62.02 \%$ & $3.10 \%$ & 3.42 & 1,083 & 12.62 \\
\hline
\end{tabular}

Note: The MCO gases are at $50^{\circ} \mathrm{C}$. In addition to hydrogen, there are 22.5 gmoles helium and 2.0 gmoles oxygen.

$\mathrm{MCO}=$ multi-canister overpack

The combustion reaction at the sampling/weld station uses 3.0 moles of oxygen, together with 6.0 moles of hydrogen. This produces an additional 6.0 moles of water vapor. The final gas mixture in the MCO is 7.1 moles helium, 7.9 moles hydrogen, and 6.0 moles water vapor. The energy liberated by the formation of the water vapor is 355,000 calories.

By an iterative process, the final temperature of the gas mixture is about $3,060 \mathrm{~K}$ $\left(2,790^{\circ} \mathrm{C}\right)$. The corresponding pressure in the $\mathrm{MCO}$ is $1,060 \mathrm{kPa}\left(10.5 \mathrm{~atm}\right.$ or $140 \mathrm{lb} / \mathrm{in}^{2}$ gauge). Because the oxygen concentration is high enough that shock waves may form, the pressure may be even higher. Before welding, the MCO design pressure is $450 \mathrm{lb} / \mathrm{in}^{2}$. In addition, the sample line and connection are designed to withstand even greater pressure. However, the sample line is vulnerable to high temperatures. When the explosion occurs, the sample line can melt enough that gases in the $\mathrm{MCO}$ rush out carrying particulate matter into the environment.

The air ingress accident leads to a similar environmental release. When the gas mixture in the $\mathrm{MCO}$ explodes, the adiabatic flame temperature reaches $2,910 \mathrm{~K}\left(2,640{ }^{\circ} \mathrm{C}\right)$. The pressure in the $\mathrm{MCO}$ is $785 \mathrm{kPa}$ (7.7 atm or $99 \mathrm{lb} / \mathrm{in}^{2}$ gauge). Because the hydrogen concentration is above 
$18 \%$, damaging shock waves may form and as much as double the pressure. Because the MCO is already open to the environment, the gases rush through the opening and carry particulate matter into the environment.

\subsection{CONSEQUENCE ANALYSIS}

The downwind doses for the contaminated helium accident are computed in the following subsections. The methodology is taken from HNF-SD-SNF-TI-059, A Discussion on the Methodology for Calculating Radiological and Toxicological Consequences for the Spent Nuclear Fuel Project at the Hanford Site. The particular inputs for this accident are the same as those used in the gaseous release accident. The risk guidelines are for an extremely unlikely event.

\subsubsection{Downwind Dose Calculation Methodology}

Inhalation doses to individuals located downwind of the CSB can be computed using the following equation (HNF-SD-SNF-TI-059). It is assumed that the individuals are not evacuated during plume passage because of the short duration of the release.

$$
\mathrm{EDE}=\mathrm{M}_{\mathrm{arr}}\left(\chi / \mathrm{Q}^{\prime}\right)(\mathrm{BR})(\mathrm{UD})
$$

where

$\mathrm{EDE}=$ the effective dose equivalent, in sieverts

$\mathrm{M}_{\text {air }}=$ the respirable quantity released into the air, $60 \mathrm{~g} \mathrm{U}$

$\chi / \mathrm{Q}^{\prime}=$ the air transport factor, $\mathrm{s} / \mathrm{m}^{3}$ (see Table 4-7)

$\mathrm{BR}=$ the average inhalation rate during the release, $3.33 \times 10^{-4} \mathrm{~m}^{3} / \mathrm{s}$

UD $=$ the committed effective dose equivalent per unit gram inhaled, 4,380 Sv/g U.

The air transport factors are for adverse wind conditions. These conditions are exceeded only $0.5 \%$ of the hours in a year. The approach used in U.S. Nuclear Regulatory Commission Regulatory Guide 1.145, Atmospheric Dispersion Models for Potential Accident Consequence Assessments at Nuclear Power Plants, was used to compute the 99.5 percentile air transport factors. Plume meander and building wake effects have not been included because the release duration following the explosion is only a few minutes. The releases are assumed to take place at ground level.

Hanford Site wind data collected at the Hanford Meteorological Station for the years 1983 to 1991 was used in computing the air transport factors. The worst-case locations are used for each receptor. The onsite individuals are $100 \mathrm{~m}$ east and $10,510 \mathrm{~m}$ west of the CSB. The offsite 
Table 4-7. Comparison of Doses with Risk Guidelines for Downwind Receptors from a Bounding Internal Hydrogen Explosion at the Canister Storage Building.

\begin{tabular}{|l|c|c|c|c|}
\hline \multirow{2}{*}{$\begin{array}{c}\text { Receptor location } \\
\text { (distance and direction) }\end{array}$} & \multirow{2}{*}{$\begin{array}{c}\text { Air transport } \\
\text { factor } \\
\left(\mathrm{s} / \mathrm{m}^{3}\right)\end{array}$} & \multicolumn{2}{|c|}{$\begin{array}{c}\text { Safety significant dose } \\
\left(\mathrm{CEDE}^{\mathrm{b}}\right)\end{array}$} & \multirow{2}{*}{$\begin{array}{c}\text { Risk } \\
\text { rem (Sv) }\end{array}$} \\
\cline { 3 - 4 } & & $\begin{array}{c}\text { Guideline } \\
(\mathrm{Sv})\end{array}$ \\
\cline { 3 - 4 } $\begin{array}{l}\text { Onsite } \\
(100 \mathrm{~m} \mathrm{E})\end{array}$ & $3.41 \mathrm{E}-02$ & $\begin{array}{c}3.0 \mathrm{E}+02 \\
(3.0 \mathrm{E}+00)\end{array}$ & $\begin{array}{c}\text { Accident } \\
\text { prevented }\end{array}$ & $\begin{array}{c}2.5 \mathrm{E}+01 \\
(2.5 \mathrm{E}-01)\end{array}$ \\
\hline $\begin{array}{l}\text { Highway } 240 \\
(10,510 \mathrm{~m} \mathrm{~W})\end{array}$ & $2.01 \mathrm{E}-05$ & $\begin{array}{c}1.8 \mathrm{E}-01 \\
(1.8 \mathrm{E}-03)\end{array}$ & $\begin{array}{c}\text { Accident } \\
\text { prevented }\end{array}$ & NA \\
\hline $\begin{array}{l}\text { Hanford Site boundary } \\
(17,390 \mathrm{~m} \mathrm{E})\end{array}$ & $1.30 \mathrm{E}-05$ & $\begin{array}{c}1.1 \mathrm{E}-01 \\
(1.1 \mathrm{E}-03)\end{array}$ & NA & $\begin{array}{c}5.0 \mathrm{E}+00 \\
(5.0 \mathrm{E}-02)\end{array}$ \\
\hline
\end{tabular}
assumed.

"Release is at ground level; release duration is less than I hour; no plume rise or plume meander has been

'Fifty-year committed effective dose equivalent from inhalation.

${ }^{\circ}$ Based on the extremely unlikely frequency, $1 \mathrm{E}-04$ to $1 \mathrm{E}-06$ per year.

$\mathrm{CEDE}=$ committed effective dose equivalent.

NA $=$ not applicable.

individual is located 17,390 m east. As shown in HNF-SD-SNF-TI-059, the computed air transport factors and unit dose factor lead to the minimum release amounts required to exceed the guidelines. The first guideline exceeded for extremely unlikely probability events is for the onsite worker location $100 \mathrm{~m}$ east of the CSB. The minimum release amount is $5.0 \mathrm{~g}$ of uranium fuel.

\subsubsection{Consequences of a Hydrogen Explosion Due to Radiolysis}

Because an explosion at the end of storage under bounding conditions has been shown to cause no harm to the $\mathrm{MCO}$, there are no consequences to discuss.

\subsubsection{Consequences of a Hydrogen Explosion Following Oxygen Addition at the Sampling/Weld Station}

For pressurized releases through a powder, the bounding release fraction is 0.005 with a respirable fraction of 0.4 (DOE-HDBK-3010-94, Section 4.4.2.3.2). Applying this to the projected bounding MCO particulate loading (HNF-SD-SNF-TI-015) of $34 \mathrm{~kg} \mathrm{UO}_{2}$, or $30 \mathrm{~kg} \mathrm{U}$, leads to a value for $\mathrm{M}_{\mathrm{\alpha ij}}$ of $60 \mathrm{~g} \mathrm{U}$. This release fraction is considered bounding because the result is based on experiments in which a pressurized gas was explosively released through a sample of powder. The hydrogen explosion during MCO handling accident involves a pressurized release in 
which the gas surrounding the powder and is suddenly released. Because the MCO vent path does not travel through the particulate it contains, the assumed release fraction is conservative.

Doses resulting from the oxygen addition event are shown on Table 4-7. The unmitigated case exceeds the onsite release guideline by a considerable margin. Therefore, safety-significant features are required to mitigate this accident.

\subsubsection{Consequences of a Hydrogen Explosion After an Air Ingress}

The same bounding release fraction used for the oxygen addition at the sampling/weld station can be used for this pressurized release. Because the same $34 \mathrm{~kg}$ uranium oxide is at risk, the same release of $60 \mathrm{~g}$ uranium fuel occurs. The resulting doses are the same as those shown in Table 4-7. Because the unmitigated case exceeds the onsite dose guideline, safety-significant features are required to mitigate this accident.

\subsection{COMPARISON TO GUIDELINES}

The consequences of a hydrogen explosion inside an $\mathrm{MCO}$ are primarily radiation doses to individuals downwind of the CSB. The internal hydrogen explosion scenario initiates a gaseous release. The projected doses, listed in Table 4-7, exceed the onsite guidelines for accidents in all probability categories. By initiating a program to ensure the helium received at the CSB is of adequate purity, the frequency of this event is reduced well below $10^{-6} /$ year. Failures by the helium supplier and CSB quality control personnel would be required for this accident to occur. Another method to eliminate such an event is to ensure the $\mathrm{MCO}$ is only depressurized enough to collect an adequate gas sample. Normal sampling is expected to lower the MCO pressure by less than $3.4 \mathrm{kPa}\left(0.5 \mathrm{lb} / \mathrm{in}^{2}\right.$ gauge $)$. Any $\mathrm{MCO}$ needing a pressure recharge after normal sampling would have a pressure near that it had when packed at the CVDF. In other words, very little hydrogen gas would be generated; thus, there would be insufficient hydrogen to cause an explosion if oxygen were added instead of helium.

For the air ingress accidents, the only mitigation is preventing accidents that would breach the MCO. Once such an accident occurs, the only way to prevent a hydrogen explosion is to keep air away from the MCO. The means to surround the MCO with an inert atmosphere exists at the CSB through the helium system and materials to construct impromptu confinement as needed.

\subsection{SUMMARY OF SAFETY-CLASS STRUCTURES, SYSTEMS, AND COMPONENTS AND TECHNICAL SAFETY REQUIREMENT CONTROLS}

No safety-class structures, systems, and components (SSCs) are required to prevent the hydrogen explosion design basis accident or to mitigate its dose consequences. Under normal operating conditions, there is no external accumulation of flammable mixtures of hydrogen and 


\section{SNF-3328 REV 0}

oxygen. Under credible or accident conditions, safety-significant controls or equipment are required to ensure flammable concentrations of oxygen internal to the $\mathrm{MCO}$ are precluded. The safety-significant equipment and technical safety requirement (TSR) controls designated to prevent the dose consequences of hydrogen explosion accidents within the $\mathrm{MCO}$ are as follows:

- Safety-significant SSC

- $\quad$ MCO (structural) - Maintain a gaseous seal such that oxygen gas cannot enter the $\mathrm{MCO}$ at a rate that would present a flammability hazard.

Good operating practices during the sampling process will not significantly depressurize the MCO. As little sample gas as possible should be taken from the MCO during sampling. Using a sampling operation that minimizes the need to refill the $\mathrm{MCO}$ with inert gas reduces the frequency with which this accident could occur. This sampling operation should be considered defense in depth for prevention of flammable gas mixtures within the $\mathrm{MCO}$ at the sampling station. The following specific TSR control prevents this event:

- TSR

- Verify helium minimum purity from sample on receipt at the CSB for any inert gas cylinders used to supply the inert gas system

- Inert the supply lines after they have been depressurized before using inert gas system

The SSCs and TSR controls designated to prevent the MCO internal hydrogen explosion accidents are summarized in Table 4-8. U.S. Nuclear Regulatory Commission important-to-safety category SSCs and defense-in-depth features also are included for each specific accident in Table 4-8.

The suite of safety SSCs and TSR controls necessary and sufficient to prevent the MCO internal hydrogen explosion accidents do not address some of the other accidents in the same accident category. Table 4-8 also lists the safety SSCs and TSR controls needed to prevent or control these accidents. Because these accidents are substantially different in development and progression from the design basis accidents, each scenario and the corresponding controls are also described below.

A hydrogen explosion (SA-J-06a, OA-J-06a, WS-F-06) during cask handling follows from excessive gas buildup in the MCO caused by radiolysis. It has been shown that the bounding case MCO will not be able to generate flammable gas mixtures even after 40 years of storage. Somewhat larger inventories of aluminum hydroxide remaining in the $\mathrm{MCO}$ after washing at $\mathrm{K}$ Basins will lead to flammable mixtures. However, combustion of these mixtures will not exceed the $450 \mathrm{lb} / \mathrm{in}^{2}$ design pressure of the MCO. To exceed this pressure limit, the key interface performance assumptions identified in Chapter 1.0, Table 1-6, must be exceeded. The following performance assumption is key to preventing this event: 
Table 4-8. Summary of Safety Features Required to Mitigate the Consequences of a Multi-Canister Overpack Internal Hydrogen Explosion. (3 sheets)

\begin{tabular}{|c|c|c|c|c|}
\hline Accident & $\begin{array}{c}\text { Checklist } \\
\text { designator }\end{array}$ & $\begin{array}{l}\text { General } \\
\text { function }\end{array}$ & Safety features and safety classification ${ }^{b}$ & $\begin{array}{l}\text { NRC ITS } \\
\text { category }\end{array}$ \\
\hline \multicolumn{5}{|c|}{ Hydrogen deflagration } \\
\hline $\begin{array}{l}\text { Hydrogen } \\
\text { explosion in } \\
\text { the MCO due } \\
\text { to use of } \\
\text { oxygen as a } \\
\text { purge gas }\end{array}$ & WS-H-06b & $\begin{array}{l}\text { Prevent oxygen } \\
\text { from entering } \\
\text { the inert gas } \\
\text { system }\end{array}$ & $\begin{array}{l}\text { Safety-significant SSCs: } \\
\text { MCO } \\
\text { TSR: } \\
\text { Verify helium minimum purity from sample on } \\
\text { receipt at the CSB for any inert gas cylinders used to } \\
\text { supply the inert gas system } \\
\text { - Inert the supply lines after they have been } \\
\text { depressurized before using inert gas system } \\
\text { Defense in depth: } \\
\text { Minimize gas loss from the MCO during sampling to } \\
\text { avoid repressurizing with helium }\end{array}$ & NA \\
\hline \multicolumn{5}{|c|}{ Deflagration } \\
\hline $\begin{array}{l}\text { Hydrogen } \\
\text { explosion } \\
\text { during cask } \\
\text { handling or } \\
\text { storage due to } \\
\text { radiolysis of } \\
\text { hydrogen and } \\
\text { oxygen } \\
\text { accumulation } \\
\text { within the } \\
\text { MCO }\end{array}$ & $\begin{array}{l}\text { SA-J-06a } \\
\text { OA-J-06a } \\
\text { WS-J-06 }\end{array}$ & & $\begin{array}{l}\text { General assumption is that all MCOs are within } \\
\text { specifications, in particular for aluminum hydroxide in } \\
\text { an MCO } \\
\text { Assumption: } \\
\text { - The K Basins washing process and the drying } \\
\text { process at the CVDF will ensure the key interface } \\
\text { performance assumptions are met. } \\
\text { Defense in depth: } \\
\text { - HVAC provides air circulation for dilution. } \\
\text { Cask head seals prevent hydrogen leakage from the } \\
\text { cask. }\end{array}$ & \\
\hline
\end{tabular}


Table 4-8. Summary of Safety Features Required to Mitigate the Consequences of a Multi-Canister Overpack Internal Hydrogen Explosion. (3 sheets)

\begin{tabular}{|c|c|c|c|c|}
\hline Accident & $\begin{array}{l}\text { Checklist } \\
\text { designator }\end{array}$ & $\begin{array}{l}\text { General } \\
\text { function }\end{array}$ & Safety features and safety classification ${ }^{b}$ & $\begin{array}{l}\text { NRC ITS } \\
\text { category }^{6}\end{array}$ \\
\hline $\begin{array}{l}\text { Hydrogen } \\
\text { explosion } \\
\text { because } \\
\text { breached MCO } \\
\text { allows air } \\
\text { ingress }\end{array}$ & OA-J-06c & $\begin{array}{l}\text { Prevent MCO } \\
\text { drops, shears, } \\
\text { impacts, and } \\
\text { collisions by } \\
\text { gas cylinders of } \\
\text { MCOs } \\
\text { Ensure MCOs } \\
\text { are within seal- } \\
\text { leak rate criteria }\end{array}$ & 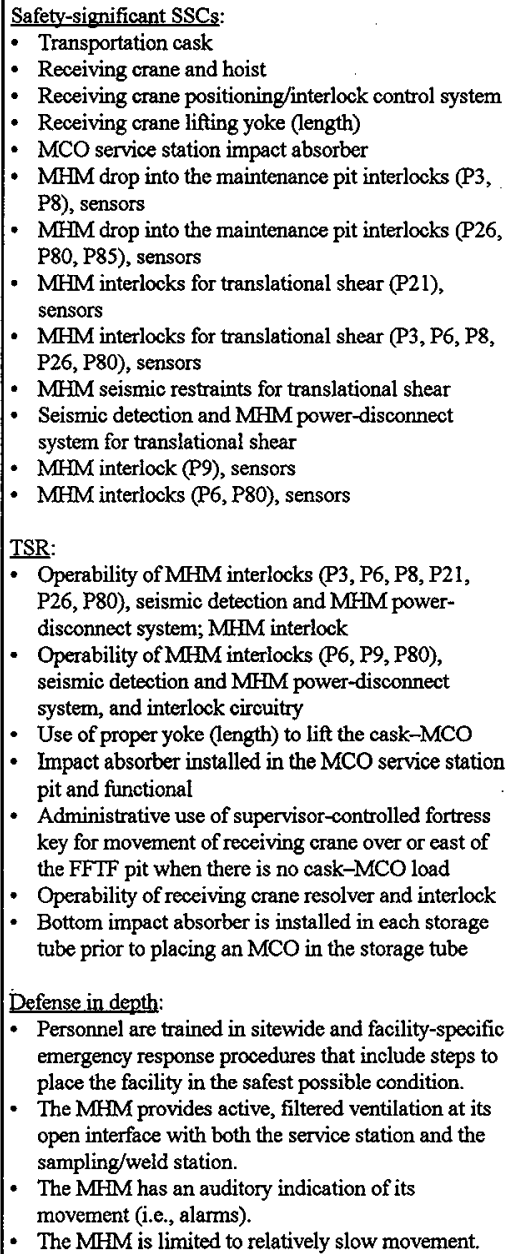 & $\begin{array}{l}\text { B } \\
\text { B } \\
\text { B } \\
\text { B } \\
\text { B } \\
\text { B } \\
\text { B } \\
\text { B } \\
\text { B } \\
\text { B } \\
\text { B } \\
\text { B } \\
\text { B }\end{array}$ \\
\hline
\end{tabular}


Table 4-8. Summary of Safety Features Required to Mitigate the Consequences of a Multi-Canister Overpack Internal Hydrogen Explosion. (3 sheets)

\begin{tabular}{|c|c|c|c|c|}
\hline Accident & $\begin{array}{c}\text { Checklist } \\
\text { designator" }\end{array}$ & $\begin{array}{l}\text { General } \\
\text { function }\end{array}$ & Safety features and safety classification ${ }^{b}$ & $\begin{array}{l}\text { NRC ITS } \\
\text { category }\end{array}$ \\
\hline $\begin{array}{l}\text { Hydrogen } \\
\text { explosion } \\
\text { because } \\
\text { breached MCO } \\
\text { allows air } \\
\text { ingress } \\
\text { (continued) }\end{array}$ & $\begin{array}{l}\text { OA-J-06c } \\
\text { (continued) }\end{array}$ & $\begin{array}{l}\text { Prevent MCO } \\
\text { drops, shears, } \\
\text { impacts, and } \\
\text { collisions by } \\
\text { gas cylinders of } \\
\text { MCOs } \\
\text { Ensure MCOs } \\
\text { are within seal- } \\
\text { leak rate criteria } \\
\text { (continued) }\end{array}$ & $\begin{array}{l}\text { Defense in depth (continued): } \\
\text { The MHM is provided with a backup grapple } \\
\text { disengagement capability. } \\
\text { - Personnel are trained to procedures detailing the safe } \\
\text { sequence of operations; these procedures prohibit } \\
\text { interferences between the receiving crane and the } \\
\text { MHM }\end{array}$ & \\
\hline
\end{tabular}

"Checklist designators are from HNF-SD-SNF-HIE-001, 1999, Canister Storage Building Hazard Analysis Report, Rev. 1, Fluor Daniel Hanford, Incorporated, Richland, Washington.

'Safety classification for DBA in this category. Safety classification or ITS category could be different for another DBA category.

$\mathrm{CSB}=$ Canister Storage Building.

DBA $=$ design basis accident.

$\mathrm{CVDF}=$ Cold Vacuum Drying Facility.

FFTF $=$ Fast Flux Test Facility.

$\mathrm{HVAC}=$ heating, ventilation, and air conditioning.

ITS $=$ important to safety.

$\mathrm{MCO}=$ multi-canister overpack .

MHM = multi-canister overpack handling machine.

NA $=$ not applicable to ITS category classification.

NRC = U.S. Nuclear Regulatory Commission.

$\mathrm{SSC}=$ structure, system, and component.

TSR $=$ technical safety requirement. 
- Assumption

- The $\mathrm{K}$ Basins washing process and the drying process at the CVDF will ensure the key performance interface assumptions defined in Chapter 1.0, Table 1-6, are met.

A different hydrogen explosion scenario (OA-J-06c) could occur following an MCO handling accident that allows gases inside the MCO to diffuse out and air to enter the MCO. At some point, a flammable mixture of hydrogen and air will be present in the MCO. Combustion of this mixture leads to a gaseous release accident. Onsite dose guidelines are exceeded. Therefore, safety-significant controls are needed to prevent the handling accidents. The following are the specific safety features and that prevent or mitigate this event:

- Safety-significant SSCs

- Transportation cask - Provides structural protection to an $\mathrm{MCO}$, when the MCO is inside a cask, from drops from the receiving crane

- Receiving crane and hoist-Required by DOE Order 6430.1A, General Design Criteria, and U.S. Nuclear Regulatory Commission equivalency important-to-safety Category B for SSCs that handle SNF

- Receiving crane positioning/interlock control system - Prevent the receiving crane from traveling over the Fast Flux Test Facility or maintenance pit when the receiving crane is carrying an $\mathrm{MCO}$

- Receiving crane lifting yoke (length) - Limits lift height above the floor (maximum of $40 \mathrm{in}$.) when the cask-MCO is being lifted by the receiving crane

- MCO service station impact absorber - Limits deceleration forces* to the MCO if the cask-MCO is dropped from the receiving crane into the MCO service station pit

- $\quad$ MHM interlocks (P3, P8) drop into the maintenance pit, sensors, and switches Ensure that the MHM turret is rotated to the navigate (TV camera) position before allowing power to the bridge or trolley drive motors when an MCO is in the MHM; the interlock circuitry includes relays, contactors, and sensors (resolvers, limit switches)

- $\quad$ MHM drop into the maintenance pit interlocks (P26, P80, P85), sensors, and switches - Prevent the MHM from rotating to the MCO position while over the maintenance pit when an MCO is in the MHM; the interlock circuitry includes relays and contactors and sensors (limit switches, photoelectric switches)

- MHM interlock (P21) for translational shear, sensors, and switches - Ensure that the MCO hoist cannot operate unless the bridge and trolley seismic restraints are 
applied when an MCO is in the MHM; the interlock circuitry includes relays, contactors, and sensors (limit switches)

- $\quad$ MHM interlocks (P3, P6, P8, P26, P80) for translational shear, sensors, and switches - Prevent the seismic restraints from disengaging and power being applied to the bridge and trolley drive motors unless the MCO hoist is fully raised when an MCO is in the MHM; the interlock circuitry includes contactors, relays, and sensors (resolvers, limit switches, photoelectric switches)

- MHM seismic restraints for translational shear - Prevent translational movement of MHM whenever engaged when an MCO is in the MHM (restraints must be engaged before MCO hoist operation)

- Seismic detection and MHM power-disconnect system for translational shear Detects seismic event (magnitude $0.74 / 3 \mathrm{~g}$ horizontal, $0.49 / 3 \mathrm{~g}$ vertical) and removes all power to the MHM; removal of power to prevent operation of the MCO hoist, disengagement of seismic restraints (MHM interlocks are not seismically qualified)

- MHM interlock (P9), sensors, and switches - Ensure that the MCO hoist cannot operate unless the turret seismic restraints are applied when an MCO is in the MHM; the interlock circuitry includes contactors, relays, and proximity sensors

- $\quad$ MHM interlocks (P6, P80), sensors, and switches - Prevent the seismic restraints from disengaging and power being applied to the turret rotational drive motors unless the MCO hoist is fully raised when an MCO is in the MHM; the interlock circuitry includes contactors, relays, and sensors (resolvers, limit switches, photoelectric switches).

- TSR

- Operability of MHM interlocks (P3, P6, P8, P21, P26, P80) and seismic detection and MHM power-disconnect system; the interlock circuitry includes relays, contactors, and sensors (resolvers, limit switches, photoelectric switches).

- Operability of MHM interlocks (P6, P9, P80) and seismic detection and MHM power-disconnect system; the interlock circuitry includes power contactors, MHM relays, mechanical switches, and sensors (resolvers, limit switches, photoelectric switches).

- Operability of interlocks and sensors (P26, P80, P85); the interlock circuitry includes contactors, relays, and sensors (resolvers, limit switches, photoelectric switches)

- Use of proper yoke (length) to lift the cask-MCO

- Impact absorber is installed in the MCO service station pit and is functional. 


\section{SNF-3328 REV 0}

- Administrative use of the supervisor-controlled fortress key for movement of receiving crane over or east of the Fast Flux Test Facility pit when there is no caskMCO loaded with SNF suspended from the crane

- Operability of receiving crane positioning/interlock control system.

- Bottom impact absorber is installed in each storage tube prior to placing an MCO in the storage tube

\subsection{REFERENCES}

ANSI/ANS-6.4.3, 1991, Gamma-Ray Attentuation Coefficients and Buildup Factors for Engineering Materials, American National Standards Institute, New York, New York.

Bulletin 503, 1952, Limits of Flammability of Gases and Vapors, U.S. Bureau of Mines, Washington, D.C.

DOE-HDBK-3010-94, 1994, Airborne Release Fractions/Rates and Respirable Fractions/Rates for Nonreactor Nuclear Facilities, U.S. Department of Energy, Washington, D.C.

DOE Order 6430.1A, General Design Criteria, U.S. Department of Energy, Washington, D.C.

HNF-3035, 1998, MCO Gas Composition for Low Reactive Surface Areas, Rev. OB, Fluor Daniel Hanford, Incorporated, Richland, Washington.

HNF-SD-SNF-HIE-001, 1998, Canister Storage Building Hazard Analysis Report, Rev. 1, Draft, Fluor Daniel Hanford, Incorporated, Richland, Washington.

HNF-SD-SNF-TI-015, 1998, Spent Nuclear Fuel Project Technical Databook, Rev. 6, Fluor Daniel Hanford, Incorporated, Richland, Washington.

HNF-SD-SNF-TI-017, 1998, Fuel Surface Area, Rev. 3, Fluor Daniel Hanford, Incorporated, Richland, Washington.

HNF-SD-SNF-TI-040, 1998, MCO Internal Gas Composition and Pressure During Interim Storage, Rev. 2, Fluor Daniel Hanford, Incorporated, Richland, Washington.

HNF-SD-SNF-TI-059, 1998, A Discussion on the Methodology for Calculating Radiological and Toxicological Consequences for the Spent Nuclear Fuel Project at the Hanford Site, Rev. 1, Fluor Daniel Hanford, Incorporated, Richland, Washington.

NUREG/CR-2726, 1983, Light Water Reactor Hydrogen Mamual, Sandia National Laboratories, Albuquerque, New Mexico. 
Regulatory Guide 1.145, 1982, Atmospheric Dispersion Models for Potential Accident Consequence Assessments at Nuclear Power Plants, Rev. 1, U.S. Nuclear Regulatory Commission, Washington, D.C. 
SNF-3328 REV 0

This page intentionally left blank. 
SNF-3328 REV 0

Figure 4-1. General Sequence for Internal Hydrogen Explosions.
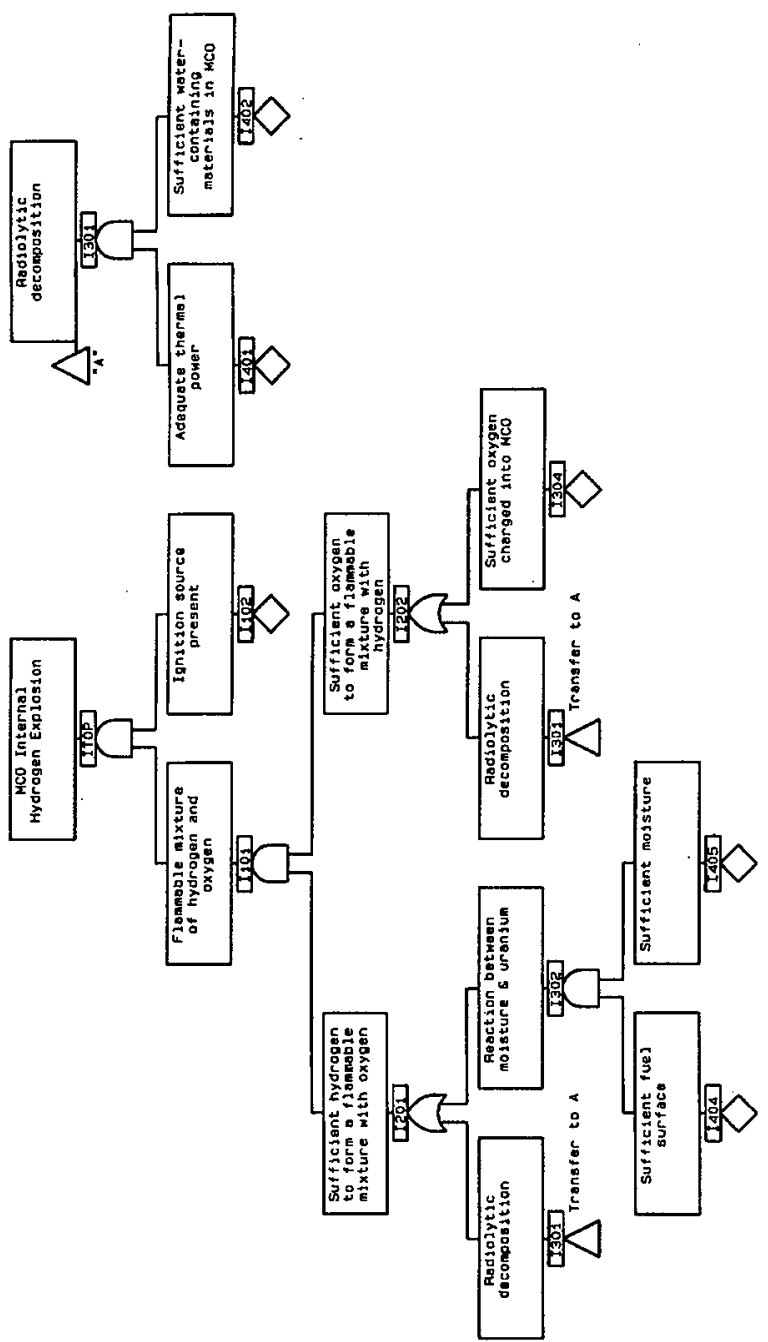
Figure 4-2. Event Diagram of a Hydrogen Explosion due to Oxygen in the Helium System.

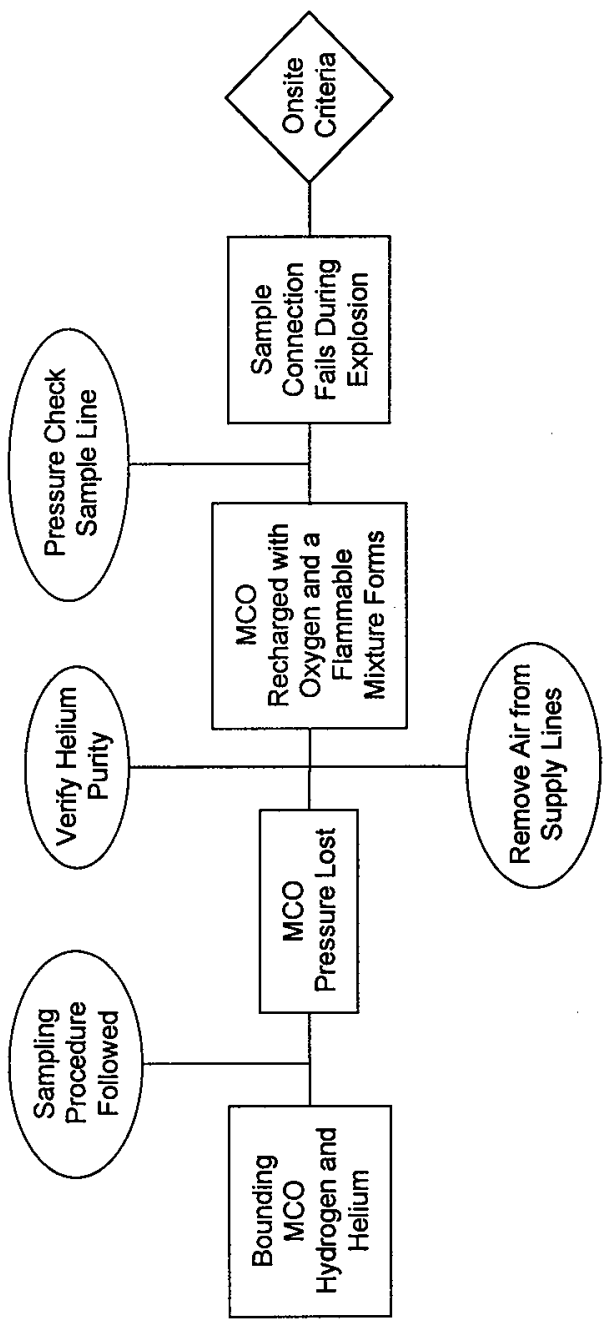


SNF-3328 REV 0

Figure 4-3. Fractions of Total Multi-Canister Overpack Power by Radiation Type.

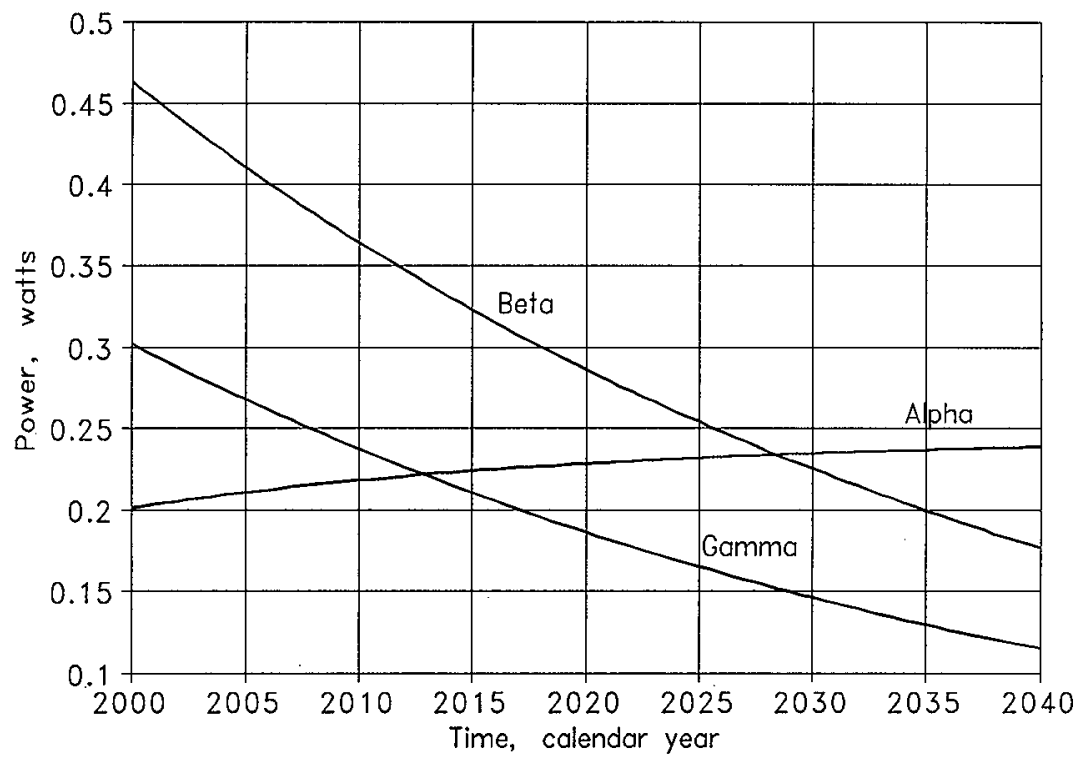


Figure 4-4. Oxygen Production (no scrap baskets; intact fuel).

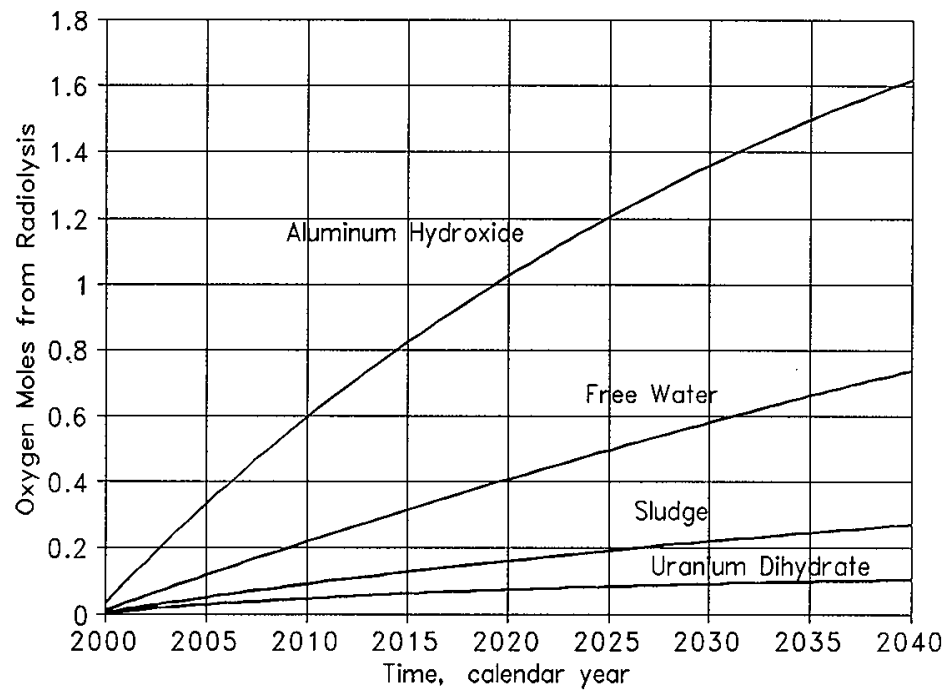


Figure 4-5. Hydrogen Production (no scrap baskets; intact fuel).

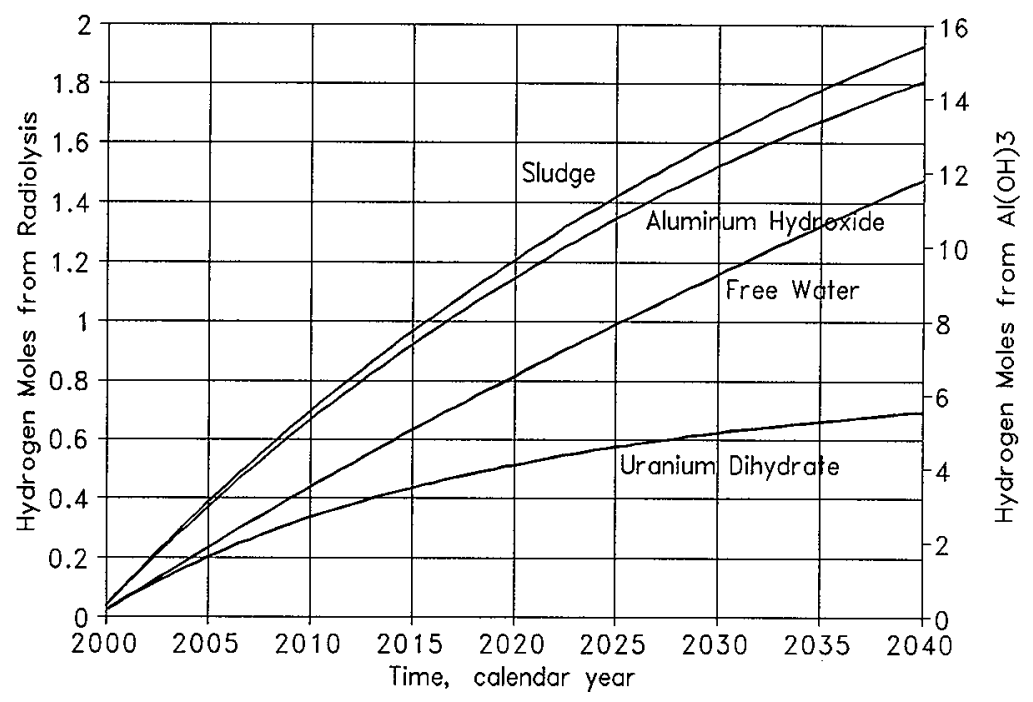




\section{SNF-3328 REV 0}

Figure 4-6. Bounding Gas Concentration and Multi-Canister Overpack Pressure.

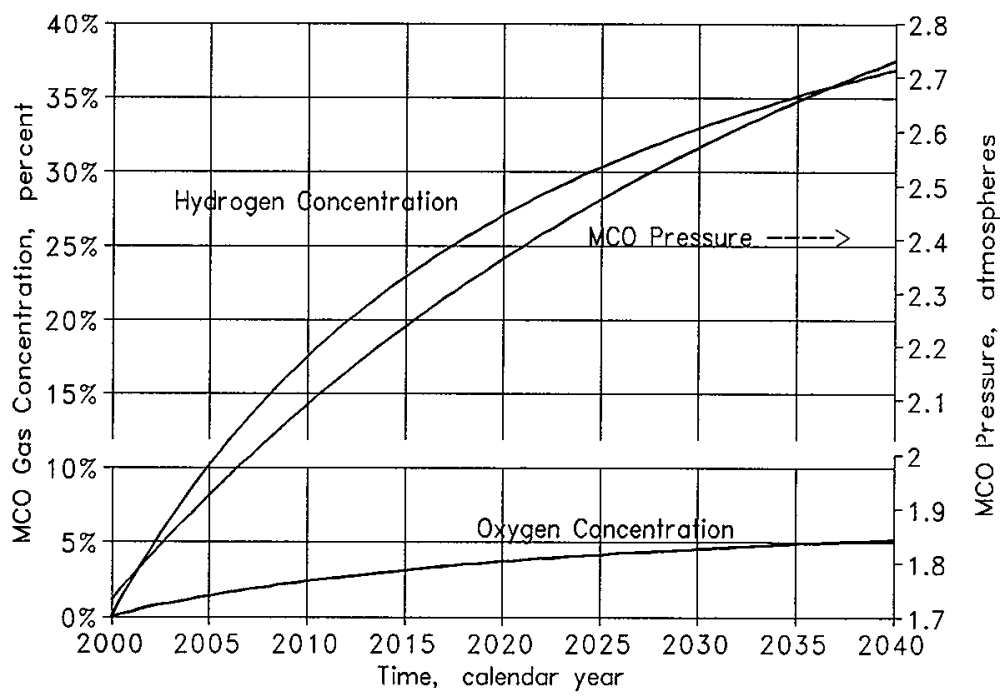




\subsection{CALCULATIONS FOR MULTI-CANISTER OVERPACK EXTERNAL HYDROGEN EXPLOSION}

\subsection{PURPOSE AND OBJECTIVES}

The evaluation of potential consequences of hydrogen explosions outside the multi-canister overpack (MCO) is summarized in this chapter. There could be occasions during the handling of a cask-MCO in the Canister Storage Building (CSB) in which significant concentrations of hydrogen could be found outside an MCO. Two event scenarios occur during venting of a cask-MCO shortly after it arrives at the CSB. In these scenarios, significant hydrogen buildup in the cask void space is vented into the containment tent exhauster and explodes. A third event scenario occurs during MCO handling when a major delay leads to excessive hydrogen concentration in the MCO handling machine (MHM). In a fourth scenario, an explosion occurs during interim storage when an off-normal leak rate leads to burnable concentrations of hydrogen in a storage tube. The other scenario occurs at the MCO sampling/weld station when a line leak into the sampling hood provides high enough hydrogen concentrations that an explosion in the hood could injure personnel at the hood. This latter accident is identified in the CSB hazard analysis (HNF-SD-SNF-HIE-001) as WS-L-11.

The accident with bounding consequences is the explosion of a hydrogen-air mixture at the sampling/weld station. This bounding accident could cause serious injury to nearby personnel. The environmental release of radioactivity to individuals located downwind are within guidelines. Mitigation strategies are discussed in Section 5.5. Required controls for each accident are summarized in Section 5.6.

\subsection{SCENARIO DEVELOPMENT}

In all postulated accident scenarios, hydrogen accumulates in an MCO because of processing delays, equipment malfunctions, or catastrophic events. The general sequence of events leading to a hydrogen explosion is shown in Figure 5-1. The accident sequence begins with the presence of enough hydrogen inside an MCO to form a flammable mixture with air outside the MCO. Three conditions necessary for hydrogen accumulation inside an $\mathrm{MCO}$ within a reasonable time frame are uranium metal and hydrides, water, and high temperatures. The uranium and water are reactants, and the elevated temperature speeds the reaction.

In this accident sequence, the accumulated hydrogen escapes the MCO and mixes with air to form a combustible mixture of hydrogen and oxygen. The mixture is then ignited. Because it takes very little energy to begin the hydrogen-oxygen combustion, it is assumed that ignition sources are present where needed. The combustion could be initiated by static electricity in ventilation ducting, a small particle of uranium hydride, static electricity in the spray nozzles in the water storage tanks, and other sources. The specific accident scenarios are described in the following subsections. 


\subsubsection{Hydrogen Explosion During Multi-Canister Overpack Cask Venting}

MCOs are transported from the Cold Vacuum Drying Facility (CVDF) to the CSB in sealed and slightly pressurized transportation casks. When a cask-MCO first arrives at the CSB, it contains helium and hydrogen in the void space. Helium is introduced at the CVDF to displace air from the void space. The hydrogen is liberated primarily by the reaction of water vapor with uranium and uranium hydrides and also by the radiolytic decomposition of water-containing compounds in the $\mathrm{MCO}$.

Hydrogen produced inside the MCO will increase the MCO pressure and could leak into the space between the MCO and the transportation cask. One method for producing an explosive mixture is shown in the Figure 5-2 block diagram.

Rough handling or some other failure at the CVDF is assumed to cause a mechanically sealed MCO to leak much faster than the maximum allowed rate. Within a shipping window of four days, enough hydrogen forms and leaks from the $\mathrm{MCO}$ and into the cask void volume to raise the gas pressure in the transportation cask. When the initial pressure check at the CSB discloses excessive pressure, the mobile service station tent is placed over the cask for contamination control. The hydrogen-gas mixture is vented to a high-efficiency particulate air (HEPA)-filtered exhaust unit. The helium purge is assumed to fail and produce a flammable mixture in the exhauster.

A spark would lead to an explosion in the ductwork near the operator and could result in serious injury. If the hydrogen-air mixture does not explode in the duct within the confinement tent, it could still explode in the ductwork near the HEPA filter and lead to significant environmental release of the radioactivity accumulated on the HEPA filter. However, the projected dose to an individual $100 \mathrm{~m}$ downwind does not exceed the dose criteria.

The hydrogen explosion during cask-MCO venting scenario is diagramed in Figure 5-2. An event tree is provided in Appendix A.

\subsubsection{Hydrogen Explosion from Receiving a Wet Cask-MCO}

A hydrogen explosion from receiving a wet cask- $\mathrm{MCO}$ is a variation on the explosion during cask venting in that the source of hydrogen in the cask is due to wet corrosion of the fuel. When a cask-MCO is ready to leave the CVDF and go to the CSB, it looks the same as a cask-MCO that has just arrived at the CVDF for drying operations. It has been assumed that at the CVDF one cask-MCO is dry and ready for shipment to the CSB at about the same time a water-filled cask-MCO arrives from $\mathrm{K}$ Basins. A process interruption causes the two casks to be mistaken and the water-filled cask-MCO is sent to the CSB. 
A small delay in processing the cask-MCO could allow for significant hydrogen accumulation. High temperature conditions during transport would reduce the time needed for significant hydrogen accumulation. The accident diagram in Figure 5-2 shows this scenario from the venting operation to the results.

\subsubsection{Hydrogen Explosion During Multi-Canister Overpack Handling}

The MHM transports MCOs within the CSB. The void space inside the MHM is filled with air and may be ventilated by a HEPA-filtered exhauster located on the turret. The HEPA filter units are located at the same level as the operating platform. If there were a major equipment breakdown that trapped a leaking MCO in the MHM for an extended period of time, then significant hydrogen could accumulate in the air around the MCO. This scenario is diagramed in Figure 5-3.

A mechanically sealed $\mathrm{MCO}$ is assumed to leak much faster than the maximum allowed rate following the MHM malfunction. A few days later, enough hydrogen has leaked from the MCO that there are flammable concentrations of hydrogen in the MHM. A flammable mixture of air and hydrogen also exists in the exhaust ducts and HEPA filter.

A spark would lead to an explosion in the ducts and HEPA filter. Any personnel nearby could be injured. An explosion could also lead to significant environmental release of the radioactivity accumulated on the HEPA filter. The projected radiation dose to any individual downwind does not exceed the dose criteria.

\subsubsection{Hydrogen Explosion During Interim Storage}

MCOs are expected to be in interim storage for about 40 years. Welded MCOs have a maximum allowable leak rate of $1 \times 10^{-7} \mathrm{~cm}^{3} / \mathrm{s}$, so that two may be placed in a storage tube. Mechanically sealed MCOs have a higher maximum allowable leak rate $\left(1 \times 10^{-5} \mathrm{~cm}^{3} / \mathrm{s}\right)$ and must be stored one to a storage tube. A high leak rate could produce flammable concentrations of hydrogen and air in the storage tube. This scenario is diagramed in Figure 5-4.

Rough handling or some other failure is assumed to cause an MCO to leak much faster than the maximum allowed rate. Within a few weeks enough hydrogen has leaked from the MCO into the storage tube to create flammable concentrations. An explosion of this mixture could damage the storage tube, but it is unlikely to exceed any safety criteria.

\subsubsection{Hydrogen Explosion During Multi-Canister Overpack Gas Sampling}

Cover cap welding on selected MCOs will be delayed for about one year to allow for gas sampling at the CSB. An MCO to be sampled is moved to the sampling pit and a sample hood is placed over the MCO. Connections are made to the MCO sample port and MCO gas is collected 
using the positive pressure of the MCO. If the connection to the MCO were to fail and discharge MCO gas into the sample hood, an explosive mixture of hydrogen and air could be formed in the hood. Because personnel are normally near the hood during this time, it is probable that an explosion in the sample hood would cause a fatal injury to the operator opening the MCO vent valve. This scenario is diagramed in Figure 5-5.

\subsection{SOURCE TERM ANALYSIS}

The mathematical analysis of the identified postulated hydrogen explosion accidents focuses on hydrogen concentration in a transportation cask, the MHM, or in a CSB storage tube. Before describing the accidents in detail, some general information relevant to all the external hydrogen accidents will be presented.

\subsubsection{Hydrogen Accumulation and Other Parameters}

Parameters and assumptions common to all, or most, of the postulated accidents are presented here. The values presented include gas volumes, helium inventory in the $\mathrm{MCO}$, air inventory in the transportation cask, hydrogen content of the $\mathrm{MCO}$ after all the available free and hydrated water has reacted with the uranium, the corresponding $\mathrm{MCO}$ pressure, the MCO leak rate, and the peak overpressures due to hydrogen combustion.

5.3.1.1 Volumes. The volumes of accumulated hydrogen are listed in Table 5-1. Because the shapes are somewhat irregular, the volumes are approximate. However, improved volume estimates will not affect the conclusions.

5.3.1.2 Helium and Air Inventory in the Multi-Canister Overpack. Before leaving the CVDF, an $\mathrm{MCO}$ is pressurized to $152 \mathrm{kPa}\left(22.1 \mathrm{lb} / \mathrm{in}^{2}\right)$ with helium. The average temperature of this helium is assumed to be $25^{\circ} \mathrm{C}$. Rather than convert gas quantities to moles, the amounts will be converted to volumes at reference conditions, namely, $25^{\circ} \mathrm{C}$ and $101.3 \mathrm{kPa}\left(14.7 \mathrm{lb} / \mathrm{in}^{2}\right)$. The conversion is carried out using the following equation, which is easily derived from the ideal gas law.

$$
\text { Vref }=(\mathrm{V})(\mathrm{P} / \text { Pref })(\text { Tref } / T)
$$

where

$$
\begin{aligned}
& \text { Vref }=\text { volume at the reference temperature and pressure, Liters } \\
& \text { Pref }=\text { reference pressure, } 101.3 \mathrm{kPa}\left(14.7 \mathrm{lb} / \mathrm{in}^{2}\right) \\
& \text { Tref }=\text { reference temperature, } 298 \mathrm{~K},\left(25^{\circ} \mathrm{C}\right) \\
& \mathrm{V}, \mathrm{P}, \mathrm{T}=\text { volume, pressure and temperature of a gas. }
\end{aligned}
$$


Table 5-1. Volumes Assumed for Hydrogen Accumulation.

\begin{tabular}{|l|c|c|}
\hline \multicolumn{1}{|c|}{ Location } & Volume, $\mathrm{L}$ & Volume, $\mathrm{ft}^{3}$ \\
\hline Free volume inside MCO & 500 & 17.7 \\
\hline Outer volume of MCO & 1,360 & 48.0 \\
\hline Inner volume of cask & 1,460 & 51.5 \\
\hline Inner volume of MHM & 2,530 & 89.3 \\
\hline Storage tube volume & 4,250 & 150.1 \\
\hline Free volume of cask & 100 & 3.5 \\
\hline Free volume of MHM & 1,170 & 41.3 \\
\hline Storage tube - one MCO & 2,890 & 102.1 \\
\hline Storage tube - two MCOs & 1,530 & 54.0 \\
\hline Sample hood & 600 & 21.2 \\
\hline
\end{tabular}

Note: These are approximate values due to the irregular shapes. More exact volumes will have no effect on the conclusions.

$\mathrm{MCO}=$ multi-canister overpack

$\mathrm{MHM}=$ multi-canister overpack handling machine .

At reference conditions, the initial volume of helium in the $\mathrm{MCO}$ is given by the formula

$$
\begin{aligned}
& \text { Vref }=(500 \mathrm{~L})(152 \mathrm{kPa} / 101.3 \mathrm{kPa})(298 \mathrm{~K} / 298 \mathrm{~K}) \\
& \text { Vref }=750 \mathrm{~L} .
\end{aligned}
$$

5.3.1.3 Bounding Hydrogen Gas in the Multi-Canister Overpack. The composition of the gas inside the MCO when it is received at the CSB is based on the assumption that there is only helium and hydrogen. The hydrogen is generated primarily by corrosion of fuel and reaction with uranium hydride. The radiolytic decomposition of water and hydroxides adds very little and has not been considered.

The bounding hydrogen content of an MCO with two scrap baskets will be estimated assuming the water reactions with uranium metal and uranium hydride occur at the same rate. From HNF-SD-SNF-TI-015, Spent Nuclear Fuel Project Technical Databook, the enhancement factor for the metal reaction is 10 while the enhancement factor for the hydride reaction is 12 . In addition, the metal reaction produces 1 mole of hydrogen gas for every mole of water reacted, but the hydride reaction produces 1.75 moles hydrogen for every mole of water reacted. The combined effect is that the hydrogen generation increases by the factor 


$$
\frac{(10)(1)+(12)(1.75)}{10+12}=1.409
$$

over the amount expected from the uranium metal reaction alone.

The hydrogen gas that could be generated from the uranium metal is limited by the amount of water available to react. The bounding free water estimate is $200 \mathrm{~g}$ in crevices and cracks. In addition, uranium oxide dihydrate will lose one of the water molecules at normal MCO temperatures (HNF-1523). Much of this loss may occur during drying at CVDF, but to maximize the hydrogen generation after drying none will be assumed. The bounding hydrated water estimate for 2 scrap baskets is $1,190 \mathrm{~g}$ water. Half of this amount is available for temperatures less than $100^{\circ} \mathrm{C}$ to react with uranium fuel to form hydrogen. The total water mass of $800 \mathrm{~g}$ is equivalent to 44 moles of water. The hydride enhancement described above leads to the bounding production of 62 moles of hydrogen in the MCO. From the ideal gas law, this hydrogen has a volume of $1,520 \mathrm{~L}$ at reference conditions.

$$
\begin{aligned}
& V=(\mathrm{n})(\mathrm{R})(\mathrm{T}) /(\mathrm{P}) \\
& \mathrm{V}=(62 \mathrm{moles})(0.082057 \mathrm{~L} \cdot \mathrm{atm} / \mathrm{mole} / \mathrm{K})(298 \mathrm{~K}) /(1 \mathrm{~atm}) \\
& V=1,520 \mathrm{~L}
\end{aligned}
$$

where.

$\mathrm{V}=$ volume of a quantity of gas at a specified temperature and pressure

$\mathrm{n}=$ number of moles of the gas

$\mathrm{R}=$ ideal gas law constant, $0.082057 \mathrm{~L} \cdot \mathrm{atm} / \mathrm{mole} / \mathrm{K}$

$\mathrm{T}=$ temperature of the gas, in kelvin

$P=$ pressure of the gas, in atmospheres $(1 \mathrm{~atm}=101.3 \mathrm{kPa})$.

To calculate the actual pressure of the gas mixture in the $\mathrm{MCO}$, the following formula is used; this formula is another variation on the ideal gas law. At $75^{\circ} \mathrm{C}$ the pressure of the helium and hydrogen mixture in the $\mathrm{MCO}$ is $537 \mathrm{kPa}\left(63 \mathrm{lb} / \mathrm{in}^{2}\right.$ gauge):

$$
\begin{aligned}
& P=(\text { Pref })(\text { Vref } / \mathrm{V})(\mathrm{T} / \text { Tref }) \\
& \mathrm{P}=(101.3 \mathrm{kPa})(750 \mathrm{~L}+1520 \mathrm{~L})(348 \mathrm{~K}) /(500 \mathrm{~L}) /(298 \mathrm{~K}) \\
& \mathrm{P}=537 \mathrm{kPa} .
\end{aligned}
$$

5.3.1.4 Multi-Canister Overpack Leak Rate Calculation. Due to an off-normal condition, the MCO is assumed to leak much faster than the bounding leak rate for a mechanically sealed MCO. The bounding leak rate is $1.0 \times 10^{-5} \mathrm{~cm}^{3} / \mathrm{s}\left(8.64 \times 10^{-4} \mathrm{~L} / \mathrm{d}\right)$ at reference conditions (HNF-2155). Reference conditions are defined as having an inside pressure of $101.3 \mathrm{kPa}\left(14.7 \mathrm{lb} / \mathrm{in}^{2}\right)$ and an 
outside pressure of $1.013 \mathrm{kPa}\left(0.147 \mathrm{lb} / \mathrm{in}^{2}\right)$, both at a temperature of $25^{\circ} \mathrm{C}$. The reference leak rate is based on volumes inside the container. A bounding formula to represent the leak rate at the postulated conditions outside the container follows. Note that no distinction is made between hydrogen and helium leak rates. The hydrogen is lighter than helium, and could diffuse more rapidly through a small leak. The formula comes from the observation that the leakage rate is proportional to the pressure difference inside and outside the cask and also the density, which is represented as pressure. The temperature adjustment is included to adjust for density change and to be consistent with the method used in the derivation of the leak rate criteria (HNF-2155).

$$
\mathrm{L}_{M C O, \text { out }}=\mathrm{L}_{x} \frac{\left(\mathrm{P}_{M C O, \text { in }}-\mathrm{P}_{M C O, \text { out }}\right)\left(\mathrm{P}_{M C O, \text { ave }}\right)\left(\mathrm{T}_{M C O, \text { out }}\right)}{\left(\mathrm{P}_{M C O, \text { out }}\right)\left(\mathrm{T}_{M C O, \text { in }}\right)}
$$

where

$$
\begin{aligned}
& \mathrm{L}_{\mathrm{MCO}, \text { out }}=\text { leak rate at the postulated conditions outside the } \mathrm{MCO} \text {, in } \mathrm{L} / \mathrm{d} \text { (or } \mathrm{L} / \mathrm{h} \text { ) } \\
& \mathrm{L}_{\star} \quad=\text { proportionality constant based on the leak rate at reference conditions, in } \mathrm{L} / \mathrm{d} \\
& \text { (or } \mathrm{L} / \mathrm{h} \text { ) per } \mathrm{kPa} \\
& \mathbf{P}_{\mathrm{MCO}, \text { in }}=\text { pressure inside the } \mathrm{MCO} \text { at postulated conditions, in } \mathrm{kPa} \\
& \mathbf{P}_{\mathrm{MCO}, \text { out }}=\text { pressure outside the } \mathrm{MCO} \text { at postulated conditions, in } \mathrm{kPa} \\
& \mathrm{P}_{\mathrm{MCO}, \mathrm{ave}}=\text { average pressure, }\left(\mathrm{P}_{\mathrm{MCO}, \mathrm{in}}+\mathrm{P}_{\mathrm{MCO}, \text { out }}\right) / 2 \text {, in } \mathrm{kPa} \\
& \mathrm{T}_{\mathrm{MCO} \text {,in }}=\text { temperature inside the } \mathrm{MCO} \text { at postulated conditions, in degrees kelvin } \\
& \mathrm{T}_{\mathrm{MCO} \text {,out }}=\text { temperature outside the } \mathrm{MCO} \text { at postulated conditions, in degrees kelvin. }
\end{aligned}
$$

The constant, $\mathrm{L}_{x}$, takes the place of more complex parameters described in HNF-2155, Multi-Canister Overpack Combustible Gas Management Leak Test Acceptance Criteria. These parameters mainly depend on the leak diameter and are weakly dependent on gas temperature. The value for $\mathrm{L}_{\mathrm{x}}$ can be obtained using reference conditions inside the container. This is shown as:

$$
\mathbf{L}_{\mathbf{x}}=\mathrm{L}_{\text {ref,in }} \frac{\left(\mathbf{P}_{\text {ref,in }}\right)}{\left(\mathbf{P}_{\text {ref,in }}-\mathbf{P}_{\text {ref,iout }}\right)\left(\mathbf{P}_{\text {ref,ave }}\right)}=L_{\text {ref, } \text { in }}\left(0.01975 \mathrm{kPa}^{-1}\right)
$$


where

$$
\begin{aligned}
& \mathrm{L}_{\mathrm{x}}=\text { proportionality constant, in } \mathrm{L} / \mathrm{d} \text { (or } \mathrm{L} / \mathrm{h} \text { ) per } \mathrm{kPa} \\
& \left.\mathrm{L}_{\text {refin }}=\text { leak rate at reference conditions inside, in } \mathrm{L} / \mathrm{d} \text { (or } \mathrm{L} / \mathrm{h}\right) \\
& \mathrm{P}_{\text {ref,in }}=\text { pressure inside the } \mathrm{MCO} \text { at reference conditions, } 101.3 \mathrm{kPa} \\
& \mathrm{P}_{\text {ref,out }}=\text { pressure outside the } \mathrm{MCO} \text { at reference conditions, } 1.013 \mathrm{kPa} \\
& \mathrm{P}_{\text {ref,ave }}=\text { average pressure, }\left(\mathrm{P}_{\text {refin }}+\mathrm{P}_{\text {ref,out }}\right) / 2=51.16 \mathrm{kPa} .
\end{aligned}
$$

The actual MCO leak rate changes with time according to the pressure difference between the $\mathrm{MCO}$ and its containment. These changes have been modeled using small time steps in spreadsheets. Specific cases are discussed below.

The leak rates modeled with the described formulas are very low. For example, a leak rate 10,000 times the criteria for a mechanically sealed MCO is $0.1 \mathrm{~cm}^{3} / \mathrm{s}$, or $8.64 \mathrm{~L} / \mathrm{d}$ at reference conditions. Such small leak rates are associated with very small holes or cracks. Thus, the associated matter released due to suspended or entrained particulate is very small and will be ignored in the analysis of external hydrogen accidents.

Hydrogen accumulation in a wet MCO, from the time it leaves the $\mathrm{K}$ Basins to the time it mistakenly arrives at the CSB, is based on the uranium corrosion equation used in the CVDF external hydrogen explosion analysis (SNF-2770). Because the values presented in that report were determined adequate to produce flammable mixtures of hydrogen and oxygen, it has been assumed that the same hydrogen accumulation takes place by the time the MCO is vented at the CSB.

5.3.1.5 Pressures Due to Hydrogen Deflagration. Mixtures of hydrogen in air are flammable in the range of $4 \%$ to $75 \%$ hydrogen by volume at atmospheric pressure and room temperature. Higher pressures and temperatures change the flammable concentration range, but these limits will be assumed for simplicity. Very damaging shock waves may be produced if the hydrogen concentration is between 18 and $58 \mathrm{vol} \%$ in air (NUREG/CR-2726). The stoichiometric ratio ( 2 moles hydrogen per 1 mole of oxygen) corresponds to $29.6 \%$ hydrogen in dry air. The presence of helium changes the stoichiometric ratio because it displaces oxygen. For example, if there are equal volume percents of hydrogen and helium, then the stoichiometric hydrogen concentration is reduced to $22.8 \%$.

When the hydrogen and oxygen react, water vapor is formed and energy is released. To be conservative, it is assumed that the energy released stays in the gas and none is lost to the MCO components. The heat capacity of the gases allows the final temperature to be computed. This final temperature, together with the number of moles of gases in the $\mathrm{MCO}$ and the ideal gas law, is used to calculate the final pressure due to the combustion.

The heat of formation of water vapor from hydrogen and oxygen gas is $57,800 \mathrm{cal} / \mathrm{mole}$ at a temperature of about $27^{\circ} \mathrm{C}$. The heat capacity of various gases is calculated from a quadratic 
formula as listed in Table 5-2. The final temperature of the gas mixture is found using the following formula. The integration is between the initial temperature of the gas mixture before combustion and the final temperature of the gas mixture after combustion. The summation is over the types of gases present in the $\mathrm{MCO}$ after combustion. Because the final gas temperature is unknown but determines the heat capacities, it must be solved by an iterative process.

$$
\left(\mathrm{H}_{\mathrm{F}}\right)\left(\mathrm{N}_{\mathrm{H} 2 \mathrm{O}}\right)=\int_{\mathrm{T}_{\mathrm{o}}}^{\mathrm{T}_{\mathrm{f}}}\left(\sum(\mathrm{Cvi})(\mathrm{Ni})\right)
$$

where

$\mathrm{H}_{\mathrm{F}} \quad$ = heat of formation of water from hydrogen and oxygen, 57,800 calories per mole formed as a vapor

$\mathrm{N}_{\mathrm{H} 2 \mathrm{O}}=$ number of moles of water formed; computed as the smaller of the number of moles of hydrogen and twice the number of moles of oxygen (prior to combustion)

$\mathrm{T}_{\mathrm{o}} \quad=$ temperature of the gas mixture before combustion, in Kelvin

$\mathrm{T}_{\mathrm{f}} \quad=$ temperature of the gas mixture after combustion, in Kelvin

$\mathrm{Cvi}=$ heat capacity at constant volume of gas "I"; depends on the temperature of the gas (represented as a quadratic equation)

$\mathrm{Ni}=$ number of moles of gas "I" after the oxygen and hydrogen react.

The pressure pulse from a hydrogen explosion exists for only a fraction of a second, but may do considerable damage to the vessel containing it. An estimate of how long this pressure exists can be obtained from the following formula for the rate of pressure increase (SFPE 1992).

$$
(\mathrm{dP} / \mathrm{dt})_{\max }=\left(\mathrm{K}_{\mathrm{G}}\right) /\left(\mathrm{V}^{1 / 3}\right)
$$

where

$$
\begin{aligned}
& (\mathrm{dP} / \mathrm{dt})_{\max }=\text { maximum rate of pressure increase, } \mathrm{kPa} / \mathrm{s} \\
& \mathrm{K}_{\mathrm{G}} \quad=\text { parameter measured for explosions in spherical containers, for hydrogen this } \\
& \text { is } 66,000 \mathrm{kPa} \cdot \mathrm{m} / \mathrm{s} \text { (SFPE 1992) } \\
& \mathrm{V}=\text { volume of the container with the burning gases, } \mathrm{m}^{3} \text {. }
\end{aligned}
$$


Table 5-2. Parameters to Determine Heat Capacities.

\begin{tabular}{|c|c|c|c|}
\hline Gas & A & B & C \\
\hline $\mathrm{H}_{2}$ & 4.959 & $-1.96 \mathrm{E}-04$ & $4.76 \mathrm{E}-07$ \\
\hline $\mathrm{N}_{2}$ & 4.470 & $1.39 \mathrm{E}-03$ & $-6.90 \mathrm{E}-08$ \\
\hline $\mathrm{O}_{2}$ & 4.130 & $3.17 \mathrm{E}-03$ & $-1.01 \mathrm{E}-06$ \\
\hline $\mathrm{H}_{2} \mathrm{O}$ & 5.149 & $2.64 \mathrm{E}-03$ & $4.59 \mathrm{E}-08$ \\
\hline $\mathrm{He}$ & 3.020 & 0 & 0 \\
\hline
\end{tabular}

Values for the heat capacity at constant volume (in cal/mole/K) are computed from the formula $\mathrm{Cv}=\mathrm{A}+\mathrm{B} \cdot \mathrm{T}+\mathrm{C} \cdot \mathrm{T}^{2}$, where $\mathrm{T}$ is the temperature of the gas. This method and parameter values are given in Whitwell and Toner, 1969, Conservation of Mass and Energy, Blaisdell Publishing Company, Waltham, Massachusetts.

The heat capacity parameters shown on this table apply to the temperature range of $300 \mathrm{~K}\left(27^{\circ} \mathrm{C}\right)$ to $1,500 \mathrm{~K}\left(1,230^{\circ} \mathrm{C}\right)$. At higher temperatures, the heat capacities are over-estimated.

Dividing the final pressure rise by the maximum rate of pressure rise leads to a bound on the shortest possible time in which the pressure could reach the peak. This minimum time is useful for estimating the motion of objects affected by the pressure pulse. As an example, an explosion in a storage tube could lift the storage tube plug.

The momentum imparted to an object affected by the pressure pulse is computed as the time-integral of the force acting on the object. As a simple approximation, the pressure is assumed to rise linearly to the peak and then fall linearly back to where it started. The total time is twice the value for $t_{\min }$ given above. The force on the object is the product of the affected surface area and the pressure. Therefore, the momentum imparted to an object is the product of the peak pressure increase $\left(\mathrm{P}_{\mathrm{x}}-\mathbf{P}_{\mathrm{o}}\right)$, the affected surface area, and the time for the pressure to rise to the peak $\left(t_{\min }\right)$. The final speed of the object is this momentum divided by its mass:

$$
\mathrm{U}=\left(\mathrm{P}_{\mathrm{x}}-\mathrm{P}_{\mathrm{o}}\right)(\mathrm{A})\left(\mathrm{t}_{\min }\right) /(\mathrm{M})
$$

where

$$
\begin{aligned}
& U=\text { speed of object affected by the pressure pulse, in } \mathrm{m} / \mathrm{s} \\
& \mathrm{P}_{\mathrm{x}}=\text { maximum pressure after completion of combustion of } \mathrm{M}_{\mathrm{H}} \text {, in } \mathrm{kPa} \\
& \mathrm{P}_{\mathrm{o}}=\text { starting pressure before combustion, } 101.3 \mathrm{kPa} \text { is used } \\
& A=\text { surface area affected by the pressure pulse, in } \mathrm{m}^{2}
\end{aligned}
$$


$t_{\min }=$ minimum time for the pressure to rise to the peak value $\left(P_{x}\right)$, in units of milli-seconds

$\mathrm{M}=$ mass of object affected by the pressure pulse, in $\mathrm{kg}$.

In the case of storage tube explosions, the speed of the object can be used to estimate how high the storage tube plug could rise following a hydrogen explosion (see Section 5.3.4). In the case of an explosion in the weld/sampling hood, this speed could indicate how fast the face of the hood moves toward the operator due to the explosion (see Section 5.3.5).

\subsubsection{Basis for Hydrogen Explosion During Multi-Canister Overpack Cask Venting}

The assumptions used in this section are selected to show that an explosive mixture of hydrogen and air is reasonably possible. These values should not be taken as limits.

Oxidation of the uranium metal by residual water vapor in the MCO pressurizes the MCO. The cask becomes pressurized due to the assumed leakage path from the MCO to the cask. No delay in shipping is required to generate the necessary hydrogen. The bounding shipping window of 4 days is enough time if the relative humidity within the MCO exceeds $5 \%$. After the cask arrives at the CSB it must be vented. If the pressure is relieved quickly there could be flammable concentrations in the exhaust. An important issue is whether enough hydrogen can form and leak to the cask during shipment so that an extraordinary delay is not needed to have flammable mixtures during venting. A delay of four days is bounding, but a delay of one year is incredible.

The basis for the hydrogen explosion during venting uses a simple time-dependent pressurization model for an MCO. It is assumed that hydrogen forms at the high rate found in the oxygen-free reaction equation. The presence of oxygen reduces the reaction rate by more than a factor of 10. If the oxygen-free equation is not appropriate then this accident would not be likely due to the need for a shipping period well beyond the bounding four days. The required shipping delay would become too long to be credible.

As an MCO is transported from the CVDF to the CSB, hydrogen is formed by oxidation of uranium. The oxygen-free formula from HNF-SD-SNF-TI-015 will be used to represent this. The weight gain due to oxygen-free water vapor reacting with uranium is

$$
\begin{gathered}
\log K=4.33-2144 / T_{\text {fuel }}+0.5 \cdot \log \left(H \cdot P_{\text {sat }}\right) \\
\log P_{\text {sat }}=7.0739-1657.46 /\left(T_{g a s}-46.11\right)
\end{gathered}
$$

where

$$
\begin{aligned}
& \mathrm{K}=\text { the weight gain, in milligrams of oxygen per square centimeter per hour } \\
& \mathrm{T}_{\text {fucl }}=\text { temperature of the uranium metal, in degrees kelvin }
\end{aligned}
$$


$\mathrm{T}_{\mathrm{gas}^{2}}=$ average temperature of the gases in the $\mathrm{MCO}$, in degrees kelvin

$\mathrm{H}=$ the relative humidity of the water vapor

$\mathrm{P}_{\text {sat }}=$ the saturated pressure of water vapor, in $\mathrm{kPa}$.

The method shown to approximate the saturation pressure of water $\left(\mathrm{P}_{\mathrm{sa}}\right)$ was taken from Chemical Process Safety Fundamentals with Applications (Crowl and Louvar 1990). The presence of water vapor also affects the pressure in the MCO. The formula for calculating the volume at reference conditions of water vapor in the MCO follows:

$$
\mathrm{V}_{\mathrm{MCO}, \mathrm{H} 2 \mathrm{O}}=(\mathrm{H})\left(\mathrm{V}_{\mathrm{MCO}}\right)\left(\mathrm{P}_{\mathrm{sat}} / \mathrm{P}_{\mathrm{ref}}\right)\left(\mathrm{T}_{\mathrm{ref}} / \mathrm{T}_{\mathrm{gas}}\right)
$$

where

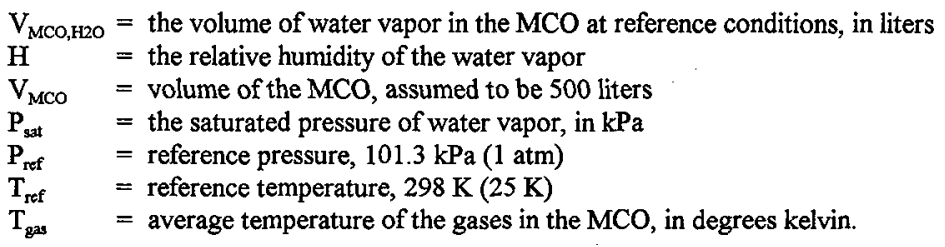

The weight gain formula represents a hydrogen generation rate in the MCO. It has been assumed that each mole of oxygen weight gain also produces 2 moles of hydrogen gas. A small amount of metal hydride may also be formed, but this reaction is assumed to be minor. Because the bounding MCO with two scrap baskets has $120,000 \mathrm{~cm}^{2}$ of exposed surface area (HNF-SD-SNF-TI-015), the production rate of hydrogen can be calculated. In addition, a fuel reaction area enhancement factor of 10 is applied to account for radiation and surface roughness (HNF-SD-SNF-TI-015). The hydrogen generation rate (grams $\mathrm{H}_{2}$ per hour) follows. For every mole of oxygen ( $16 \mathrm{~g}$ oxygen) added to the metal, 2 moles of hydrogen $\left(2 \mathrm{~g} \mathrm{H}_{2}\right)$ are produced. In addition, the hydride enhancement factor (1.409) is also used.

$$
\text { Rate }\left(\mathrm{H}_{2}\right)=(\mathrm{K})\left(120,000 \mathrm{~cm}^{2}\right)(10) \frac{2 \mathrm{~g} \text { hydrogen }}{16 \mathrm{~g} \text { oxygen }}(1.409)
$$

The hydrogen generation rate depends on the number of scrap baskets. An MCO with two scrap baskets has a safety basis fuel area of $120,000 \mathrm{~cm}^{2}$ together with a hydrate water inventory of $1,190 \mathrm{~g}$. An MCO with a single scrap basket has a safety basis fuel area of $80,000 \mathrm{~cm}^{2}$ together with a hydrate inventory of $777 \mathrm{~g}$. Both cases lead to flammable mixtures while venting the cask. The two scrap basket case produces a more severe explosion.

The hydrogen generation rate also depends on the assumed fuel temperature. After leaving the CVDF, the average fuel temperature in the MCO under bounding conditions is assumed to increase from $30^{\circ} \mathrm{C}$ to $65^{\circ} \mathrm{C}$. The bounding conditions involve hot weather as indicated in the 
shipping thermal analysis for the safety analysis report for packaging (HNF-SD-TP-SARP-017). To represent the temperature history, the following formula is used. The parameters were selected so that half of the temperature increase occurs during the first 12 hours. A graph of the assumed temperatures during transfer to the CSB is shown in Figure 5-6.

$$
T_{M C O, f u e l}=(338 \mathrm{~K})-(35 \mathrm{~K}) \cdot \operatorname{Exp}\left(-\left(0.05776 \mathrm{~h}^{-1}\right) \cdot \mathrm{t}\right)
$$

where

$\mathrm{T}_{\text {MCo,fuel }}=$ the average fuel temperature, in degrees kelvin

$\mathrm{t}=$ the elapsed time since leaving CVDF, in hours.

The average temperature of the gas in the MCO is assumed to be several degrees lower than the fuel temperature but follows the same time dependence. While the fuel temperature is assumed to increase from $30^{\circ} \mathrm{C}$ to $65^{\circ} \mathrm{C}$, the $\mathrm{MCO}$ gas temperature is assumed to increase from $25^{\circ} \mathrm{C}$ to $50^{\circ} \mathrm{C}$. Similarly, the temperature in the cask is assumed to increase from $25^{\circ} \mathrm{C}$ to $30^{\circ} \mathrm{C}$. Simple linear interpolation is used to construct the gas temperatures:

$$
\mathrm{Tx}, \mathrm{t}=\mathrm{Tx}, \mathrm{i}+(\mathrm{Tm}, \mathrm{t}-\mathrm{Tm}, \mathrm{i})(\mathrm{Tx}, \mathrm{f}-\mathrm{Tx}, \mathrm{i}) /(\mathrm{Tm}, \mathrm{f}-\mathrm{Tm}, \mathrm{i})
$$

where

$\mathrm{Tx}, \mathrm{t}=$ gas temperature in the MCO or cask at some intermediate time

$\mathrm{Tx}, \mathrm{i}=$ gas temperature in the MCO or cask initially (leaving CVDF)

$\mathrm{Tx}, \mathrm{f}=$ gas temperature in the MCO or cask finally (arriving at CSB)

$\mathrm{Tm}, \mathrm{t}=$ fuel temperature in the $\mathrm{MCO}$ at some intermediate time

$\mathrm{Tm}, \mathrm{i}=$ fuel temperature in the MCO initially (leaving CVDF)

$\mathrm{Tm}, \mathrm{f}=$ fuel temperature in the MCO finally (arriving at CSB).

The number of grams of water in the MCO that can contribute to the generation of hydrogen is limited. The bounding mass of free water after drying is $200 \mathrm{~g}$. In addition, the bounding mass of hydrated oxides of uranium (two scrap basket case) is $1,190 \mathrm{~g}$. Of this mass of hydrate water, about half may be freed by thermal decomposition and thus contribute to hydrogen generation (HNF-1523). The rate at which this water becomes available increases with temperature. This water is assumed available from the start. The actual temperature dependence of the release of hydrate would slow the hydrogen buildup. Because temperatures are assumed to rise rapidly during shipment from the CVDF, this additional delay should be less than one day.

The representation of pressures and gas concentrations in the MCO and transportation cask uses the following equations. A spreadsheet was prepared to implement this model. Note that all volumes have been converted to reference temperature and pressure conditions.

Approximation for the $\mathrm{MCO}$ :

$$
V_{M C O, H 2, J+1}=V_{M C O, H 2, J}+d V_{o x, H 2, J}-d V_{M C O, t o t,}\left(V_{M C O, H 2, J}\right) /\left(V_{M C O, L o t, 5}\right)
$$




\section{SNF-3328 REV 0}

$$
\begin{aligned}
& \mathrm{V}_{\mathrm{MCO}, \mathrm{Hot}, \mathrm{J}}=\mathrm{V}_{\mathrm{MCO}, \mathrm{H} 2, \mathrm{~J}}+\mathrm{V}_{\mathrm{MCO}, \mathrm{He}, \mathrm{J}}+\mathrm{V}_{\mathrm{MCO}, \mathrm{H} 2 \mathrm{O}, \mathrm{J}} \\
& V_{M C O, H e, J+1}=V_{M C O, H e, J}-d V_{M C O, \text { tot }, J}\left(V_{M C O, H G, J}\right) /\left(V_{M C O, \text { tot }, 3}\right) \\
& \mathrm{dV}_{\mathrm{ox}, \mathrm{H} 2, \mathrm{~J}} / \mathrm{dt}=\operatorname{Rate}\left(\mathrm{H}_{2}\right)_{\mathrm{J}} \cdot\left(1 \mathrm{~mole} \mathrm{H}_{2}\right) /\left(2 \mathrm{~g} \mathrm{H}_{2}\right) \cdot \mathrm{R} \cdot\left(\mathrm{T}_{\mathrm{ref}} / \mathrm{P}_{\mathrm{ret}}\right) \\
& \mathrm{dV}_{\mathrm{MCO}, \mathrm{tot}, J} / \mathrm{dt}=\left(\mathrm{L}_{\mathrm{x}}\right)\left(\mathrm{P}_{\mathrm{MCO}, \mathrm{J}}-\mathrm{P}_{\text {cask }, \mathrm{J}}\right)\left(\mathrm{P}_{\text {cask }, \mathrm{J}}+\mathrm{P}_{\mathrm{MCO}, \mathrm{J}}\right)\left(\mathrm{T}_{\mathrm{ref}} / \mathrm{P}_{\mathrm{ref}}\right) / 2 \\
& \mathrm{P}_{\mathrm{MCO}, \mathrm{J}}=\left(\mathrm{P}_{\mathrm{ref}}\right)\left(\mathrm{T}_{\mathrm{MCO}, \mathrm{J}} / \mathrm{T}_{\mathrm{ref}}\right)\left(\mathrm{V}_{\mathrm{MCO}, \mathrm{to}, \mathrm{J}} \mathrm{J}\right) /\left(\mathrm{V}_{\mathrm{MCO}}\right)
\end{aligned}
$$

Approximation for the Cask:

$$
\begin{aligned}
& \mathrm{V}_{\text {cask, } \mathrm{H} 2, \mathrm{~J}+1}=\mathrm{V}_{\text {cask } \mathrm{H} 2, \mathrm{~J}}+d \mathrm{~V}_{\mathrm{MCO}, \mathrm{tot}, 3}\left(\mathrm{~V}_{\mathrm{MCO}, \mathrm{H} 2, \mathrm{~J}}\right) /\left(\mathrm{V}_{\mathrm{MCO}, \text { tot } \mathrm{J}}\right) \\
& \mathrm{V}_{\text {cask }, \mathrm{He}, \mathrm{J}+1}=\mathrm{V}_{\text {cask, } \mathrm{He}, \mathrm{J}}+d \mathrm{~V}_{\mathrm{MCO}, \mathrm{tot}, \mathrm{S}}\left(\mathrm{V}_{\mathrm{MCO}, \mathrm{He}, \mathrm{J}}\right) /\left(\mathrm{V}_{\mathrm{MCO}, \mathrm{tot}, \mathrm{J}}\right)
\end{aligned}
$$

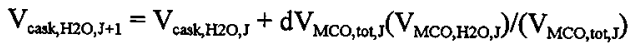

$$
\begin{aligned}
& P_{\text {cask }, \mathrm{J}}=\left(P_{\text {ref }}\right)\left(T_{\text {cask }, J} / T_{\text {ref }}\right)\left(V_{\text {cask,H2,J }}+V_{\text {cask,He, } J}+V_{\text {cask, air }}\right) /\left(V_{\text {cask }}\right)
\end{aligned}
$$

where

$$
\begin{aligned}
& \mathrm{V}_{\mathrm{MCO}, \mathrm{H} 2, \mathrm{~J}+1}=\text { volume of hydrogen in the } \mathrm{MCO} \text { at time step } \mathrm{J}+1 \text {, in liters at reference } \\
& \mathrm{V}_{\mathrm{MCO}, \mathrm{H} 2, \mathrm{~J}}=\text { volume of hydrogen in the } \mathrm{MCO} \text { at time step } \mathrm{J} \text {, in liters at reference } \\
& \text { temperature and pressure } \\
& \mathrm{V}_{\mathrm{MCO}, \mathrm{He}, \mathrm{J}+1}=\text { volume of helium in the } \mathrm{MCO} \text { at time step } \mathrm{J}+1 \text {, in liters at reference } \\
& \text { temperature and pressure } \\
& \mathrm{V}_{\mathrm{MCO}, \mathrm{He}, \mathrm{S}}=\text { volume of helium in the } \mathrm{MCO} \text { at time step } \mathrm{J} \text {, in liters at reference } \\
& \text { temperature and pressure } \\
& \mathrm{V}_{\mathrm{MCO}, \mathrm{HzO}, \mathrm{J}}=\text { volume of water vapor in the } \mathrm{MCO} \text { at time step } \mathrm{J} \text {, in liters at reference } \\
& \text { temperature and pressure } \\
& \mathrm{V}_{\mathrm{MCO}, \text { tot }, \mathrm{I}}=\text { total volume of gas in the } \mathrm{MCO} \text { at time step } \mathrm{J} \text {, in liters at reference } \\
& \text { temperature and pressure } \\
& \mathrm{V}_{\mathrm{cask}, \mathrm{H} 2, \mathrm{~J}+1}=\text { volume of hydrogen in the cask at time step } \mathrm{J}+1 \text {, in liters at reference } \\
& \text { temperature and pressure } \\
& \mathrm{V}_{\text {cask,H2, }}=\text { volume of hydrogen in the cask at time step } \mathrm{J} \text {, in liters at reference } \\
& \text { temperature and pressure }
\end{aligned}
$$




$$
\begin{aligned}
& \mathrm{V}_{\mathrm{cask}, \mathrm{He}, \mathrm{J}+1}=\text { volume of helium in the cask at time step } \mathrm{J}+1 \text {, in liters at reference } \\
& \text { temperature and pressure } \\
& \mathrm{V}_{\text {cask,He, } \mathrm{J}}=\text { volume of helium in the cask at time step } \mathrm{J} \text {, in liters at reference } \\
& \text { temperature and pressure } \\
& \mathrm{V}_{\text {cask,H20,J+1 }}=\text { volume of water vapor in the cask at time step } \mathrm{J}+1 \text {, in liters at reference } \\
& \text { temperature and pressure } \\
& \mathrm{V}_{\text {cask, H2O, } \mathrm{J}}=\text { volume of water vapor in the cask at time step } \mathrm{J} \text {, in liters at reference } \\
& \text { temperature and pressure } \\
& \mathrm{dV}_{\mathrm{Ox}, \mathrm{H} 2, \mathrm{~J}} / \mathrm{dt}=\text { rate of change in volume of hydrogen gas in the } \mathrm{MCO} \text { due to oxidation of } \\
& \text { uranium fuel at time step } \mathrm{J} \text {, in liters per hour at reference temperature and } \\
& \text { pressure } \\
& \mathrm{dV}_{\mathrm{MCO}, \text { tot }} / \mathrm{dt}=\text { rate of change in volume of gas in the MCO due to leakage to the cask at } \\
& \text { time step } \mathrm{J} \text {, in liters per hour at reference temperature and pressure } \\
& \operatorname{Rate}\left(\mathrm{H}_{2}\right)_{\mathrm{J}} \quad=\text { rate at which hydrogen is produced in the MCO at time step } \mathrm{J} \text {, in grams per } \\
& \text { hour } \\
& \mathrm{R}=\text { ideal gas law constant, } 0.082057 \mathrm{~L} \cdot \mathrm{atm} / \mathrm{gmole} /{ }^{\circ} \mathrm{K} \\
& \mathrm{L}_{\mathrm{x}} \quad=\text { leak rate proportionality constant, } \mathrm{L} / \mathrm{h} \text { per } \mathrm{kPa} \\
& \mathbf{P}_{\text {ref }} \quad=\text { reference pressure, } 101.3 \mathrm{kPa}(1 \mathrm{~atm}) \\
& \mathrm{T}_{\text {ref }} \quad=\text { reference temperature, } 298 \mathrm{~K}(25 \mathrm{~K}) \\
& \mathrm{P}_{\mathrm{MCO}, \mathrm{I}}=\text { pressure inside the } \mathrm{MCO} \text { at time step } \mathrm{J} \text {, in } \mathrm{kPa} \\
& \mathrm{V}_{\mathrm{MCO}}=\text { volume of the } \mathrm{MCO} \text {, assumed to be } 500 \mathrm{~L} \\
& \mathrm{~T}_{\mathrm{MCO}, \mathrm{J}}=\text { temperature of gas in the } \mathrm{MCO} \text { at time step } \mathrm{J} \text {, in degrees kelvin } \\
& \mathrm{P}_{\text {cask, } \mathrm{J}} \quad=\text { pressure inside the cask at time step } \mathrm{J} \text {, in } \mathbf{k P a} \\
& \mathrm{V}_{\text {cask }} \quad=\text { free volume of the cask with an } \mathrm{MCO} \text {, assumed to be } 100 \mathrm{~L} \\
& \mathbf{T}_{\text {cask, }}=\text { temperature inside the cask, in degrees kelvin. }
\end{aligned}
$$

The pressures in the MCO and cask are shown in Figure 5-7 for two relative humidities, 2\% and $50 \%$. It can be seen that this model has the MCO pressure rising until all the water is used up. After the available water is used the pressure begins to decrease due to leakage to the cask. 
The slope of the pressure curve for the cask begins to decrease at this point because gas is entering the cask at a decreasing rate. Relative humidity affects how long it takes to reach the transition. Higher humidities use the water more quickly and reach the transition sooner. The corresponding hydrogen concentration curves are shown in Figure 5-8 for three relative humidities $(2 \%, 10 \%$, and $50 \%)$.

Because the humidity in the $\mathrm{MCO}$ primarily affects the time required to pressurize the cask, it will be assumed that the relative humidity is $10 \%$. Higher or lower humidities will not affect the conclusion.

According to the above model, the cask temperature and pressure are $30^{\circ} \mathrm{C}$ and $284 \mathrm{kPa}$ ( $26.6 \mathrm{lb} / \mathrm{in}^{2}$ gauge) after 4 days at a leak rate 10,000 times greater than allowed for a mechanically sealed MCO. The gas concentrations in the cask are $32 \%$ hydrogen, $32 \%$ helium, $7.6 \%$ oxygen, $29 \%$ nitrogen, and $0.1 \%$ water vapor as shown on Table 5-3. The corresponding volumes (at $25^{\circ} \mathrm{C}$ and $1 \mathrm{~atm}$ ) are $88 \mathrm{~L}$ hydrogen, $88 \mathrm{~L}$ helium, $21 \mathrm{~L}$ oxygen, $79 \mathrm{~L}$ nitrogen, and $0.3 \mathrm{~L}$ water vapor for a total of $276 \mathrm{~L}$.

Table 5-3. Hydrogen and Oxygen Volumes at the Time of Venting.

\begin{tabular}{|l|c|c|c|}
\hline \multicolumn{1}{|c|}{ Identifier } & Hydrogen & Oxygen & Total \\
\hline MCO free space & $980 \mathrm{~L}$ & $0 \mathrm{~L}$ & $1,650 \mathrm{~L}$ \\
$(500 \mathrm{~L}$ at $362 \mathrm{kPa}$ and $323 \mathrm{~K})$ & $(60 \%)$ & $(0 \%)$ & \\
\hline Cask free space & $88 \mathrm{~L}$ & $21 \mathrm{~L}$ & $276 \mathrm{~L}$ \\
$(100 \mathrm{~L}$ at $279 \mathrm{kPa}$ and $303 \mathrm{~K})$ & $32 \%$ & $7.6 \%$ & \\
\hline Vented at CSB & $56 \mathrm{~L}$ & $13 \mathrm{~L}$ & $176 \mathrm{~L}$ \\
& $32 \%$ & $7.6 \%$ & \\
\hline 1 second flow from exhauster & 0 & $99 \mathrm{~L}$ & $472 \mathrm{~L}$ \\
& & $21 \%$ & \\
\hline Exhauster mixture & $56 \mathrm{~L}$ & $112 \mathrm{~L}$ & $648 \mathrm{~L}$ \\
& $8.7 \%$ & $17 \%$ & \\
\hline
\end{tabular}

Volumes have been converted to reference temperature and pressure. Reference temperature is $25^{\circ} \mathrm{C}$ and reference pressure is $101.3 \mathrm{kPa}(14.7 \mathrm{psia})$. Gas concentrations are shown below the respective volumes. The "Total" column includes the helium and nitrogen and any water vapor.

$\mathrm{CSB}=$ Canister Storage Building.

$\mathrm{MCO}=$ multi-canister overpack.

Note that the mixture of gases in the cask is combustible. If it were ignited, at most $3.5 \mathrm{~g}$ hydrogen would burn, assuming all the available oxygen was combusted. The maximum pressure during combustion uses the starting pressure of $284 \mathrm{kPa}$ and reaches $1,820 \mathrm{kPa}\left(249 \mathrm{lb} / \mathrm{in}^{2}\right.$ gauge). This exceeds the design pressure for the cask and would cause it to rupture. The 
contamination available for resuspension is minimal because the MCO is sealed. In addition, personnel are not normally near the cask; therefore, the explosion of the cask will not be evaluated in further detail. However, because the MCO is leaking and the cask is breached by the hydrogen explosion, there is a loss of confinement.

Because the cask is pressurized, the mobile service station tent is placed over it before venting and purging the cask free space. The tent provides contamination control. The confinement tent is ventilated by a portable exhauster located outside the tent. It will be assumed that this exhauster operates at $1,000 \mathrm{ft}^{3} / \mathrm{min}$. If the gases in the cask are vented suddenly, then the lower explosive limit could be exceeded in the exhauster ductwork. If, in this example the cask is vented in one second, $(276-100) \mathrm{L}=176 \mathrm{~L}$ vents into the exhaust system. In that one second the cask gases would mix with $472 \mathrm{~L}$ of air. The total volume of the mixture is thus $648 \mathrm{~L}$. The resulting hydrogen concentration is $(32 \%)(176 \mathrm{~L}) /(648 \mathrm{~L})=8.7 \%$, which exceeds the lower explosive limit. The hydrogen and oxygen volumes calculated above are summarized in Table 5-3 for clarity.

The total volume of hydrogen introduced to the exhaust system is $56 \mathrm{~L}$ at $25^{\circ} \mathrm{C}$ and atmospheric pressure. This corresponds to $4.6 \mathrm{~g}$ of hydrogen undergoing complete combustion. Because the combustion of $1 \mathrm{~g}$ of hydrogen releases the same thermal energy as $28.65 \mathrm{~g}$ of TNT (NUREG-1320), the $4.6 \mathrm{~g}$ of hydrogen is comparable to $133 \mathrm{~g}$ of TNT. The damage created by the hydrogen is less than that from TNT because the hydrogen is spread over a large volume and burns slower. Nevertheless, some damage to the duct and HEPA filter can be expected. The adiabatic flame temperature is $1,250 \mathrm{~K}$, thus the bounding pressure in the duct is $407 \mathrm{kPa}$ (44 lb/in ${ }^{2}$ gauge).

If a wet MCO were brought to the CSB due to a mixup at the CVDF, the venting operation would not detect the presence of water because the upper cask port is used for the pressure measurement connection. The venting operation would also exceed $4 \%$ hydrogen in the exhauster if the bounding case hydrogen accumulation were to occur. The external hydrogen explosion analysis for the CVDF (SNF-2770) shows that after 24 hours the bounding pressure in the cask-MCO is $1,135 \mathrm{kPa}\left(165 \mathrm{lb} / \mathrm{in}^{2}\right.$ absolute $)$ at $25^{\circ} \mathrm{C}$. The void space in the wet cask is about $38 \mathrm{~L}$. Thus, the gas volume at reference temperature and pressure is given by:

$$
\begin{aligned}
& \text { Vref }=(38 \mathrm{~L})(1135 \mathrm{kPa} / 101.3 \mathrm{kPa})(298 \mathrm{~K} / 298 \mathrm{~K}) \\
& \text { Vref }=428 \mathrm{~L} .
\end{aligned}
$$

From the molar concentrations given in SNF-2770, Cold Vacuum Drying Facility Design Basis Accident Analysis Documentation, the hydrogen concentration is $89 \%$. It is assumed that no oxygen is present because the cask was filled with helium at the $\mathrm{K}$ Basins. The volume of hydrogen to be vented is therefore $(89 \%)(428 \mathrm{~L}-38 \mathrm{~L})=348 \mathrm{~L}$. This is a larger volume of hydrogen than before, and it could produce high enough concentrations in the exhauster to form shock waves as it burns. 
If the hydrogen in the exhaust duct were ignited near the exhauster HEPA filter, the resulting pressure wave could damage the HEPA filter and its housing, allowing radioactive contamination on the filter to enter the process bay or the environment.

The amount of radioactivity released to the environment by a hydrogen explosion near the exhauster HEPA filter has been estimated using bounding assumptions. For example, it is assumed that the HEPA filter housing reads $50 \mathrm{mR} / \mathrm{h}$ at the time of the explosion. HEPA filters normally are changed when the differential pressure becomes too large, indicating that the filter is becoming plugged. An additional administrative criterion is the dose rate on the filter housing at a point nearest the filters. Because the filters must be changed by hand, the exposure to personnel working nearby and especially during filter changeout would be excessive if a dose rate limit were not in place.

Using the safety/regulatory basis spent fuel composition (HNF-SD-SNF-TI-059), the dose rates to the side of a single HEPA filter has been estimated using the ISO-PC software (WHC-SD-WM-UM-030). The filter is assumed to be $61 \mathrm{~cm}$ by $61 \mathrm{~cm}$ by $30 \mathrm{~cm}$. The filter medium is homogenized throughout this volume at a density of $0.16 \mathrm{~g} / \mathrm{cm}^{3}$, corresponding to a filter weight of $18.1 \mathrm{~kg}$. Assuming an administrative dose rate limit of $50 \mathrm{mR} / \mathrm{h}$ to the side of the HEPA filter, then $1.5 \mathrm{~g}$ of spent fuel is present on the filter. Additional details and the program output are included in Appendix B.

\subsubsection{Hydrogen Explosion During Multi-Canister Overpack Handling}

Soon after arrival at the CSB, the pressure in the bounding MCO reaches about $537 \mathrm{kPa}$ (63 lb/in ${ }^{2}$ gauge) if the MCO vapor space is oxygen free. The gas in the MCO is $67 \%$ hydrogen and $33 \%$ helium. It has been assumed that some accident occurs while an $\mathrm{MCO}$ is being transported from one location to another inside the CSB. The MHM is immobilized with the MHM ventilation system out of service. In addition, the MCO begins to leak much faster than the leak rate criteria.

As gas slowly leaves the MCO, the pressure decreases. It is assumed that the gases leave the $\mathrm{MCO}$ at a rate proportional to their concentration. Diffusion effects are considered minimal compared to convective flow effects. The air space around the MCO is ventilated by natural circulation only. Thus, clean air continually enters the MHM air space while a mixture of air, hydrogen, and helium continually leaves. The representation of gas concentrations in the MHM uses the equations below. Note that all volumes have been converted to reference temperature and pressure conditions.

Approximation for the MCQ:

$$
\begin{aligned}
& \mathrm{V}_{\mathrm{MCO}, \mathrm{tot}, \mathrm{J}+1} \doteq \mathrm{V}_{\mathrm{MCO}, \mathrm{tot}, \mathrm{J}}-\mathrm{dV}_{\mathrm{MCO}, \mathrm{lot}, \mathrm{J}} \\
& \mathrm{dV}_{\mathrm{MCO}, \mathrm{to}, \mathrm{J}} / \mathrm{dt}=\left(\mathrm{L}_{\mathrm{x}}\right)\left(\mathrm{P}_{\mathrm{MCO}, \mathrm{J}}-\mathrm{P}_{\mathrm{MHM}}\right)\left(\mathrm{P}_{\mathrm{MHM}}+\mathrm{P}_{\mathrm{MCO}, \mathrm{J}}\right)\left(\mathrm{T}_{\mathrm{ref}} / \mathrm{P}_{\mathrm{ref}}\right) / 2
\end{aligned}
$$




$$
P_{M C O, J}=\left(P_{\text {ref }}\right)\left(T_{M C O, J}\right) /\left(T_{\text {ref }}\right)\left(V_{M C O, \text { tot }, J}\right) /\left(V_{M C O}\right)
$$

Approximation for the MHM:

$$
\begin{aligned}
& \mathrm{C}_{\mathrm{MHM}, \mathrm{Hx}, \mathrm{J}+1}=\left(\mathrm{C}_{\mathrm{MHM}, \mathrm{HX}, \mathrm{J}}\right)\left[1-\left(\mathrm{dV}_{\mathrm{MCO}, \mathrm{tot} J}+\mathrm{dV}_{\mathrm{git}}\right) /\left(\mathrm{V}_{\mathrm{MHM}}\right)\right]+\left(\mathrm{C}_{\mathrm{MCO}, \mathrm{Hx}}\right)\left(\mathrm{dV}_{\mathrm{MCO}, \mathrm{tot}, \mathrm{J}}\right) /\left(\mathrm{V}_{\mathrm{MHM}}\right) \\
& \mathrm{C}_{\mathrm{MHM}, \text { air }, J+1}=\left(\mathrm{C}_{\mathrm{MHM}, \text { air, }, J}\right)\left[1-\left(\mathrm{dV}_{\mathrm{MCO}, \text { to }, \mathrm{J}}+\mathrm{dV}_{\text {air }}\right) /\left(\mathrm{V}_{\mathrm{MHAM}}\right)\right]+\left(\mathrm{C}_{\mathrm{CSB}, \text { air }}\right)\left(\mathrm{dV}_{\text {air }}\right) /\left(\mathrm{V}_{\mathrm{MHM}}\right)
\end{aligned}
$$

where

$$
\begin{aligned}
& \mathrm{V}_{\mathrm{MCO}, \text { tot }, \mathrm{J}+1}=\text { volume of gas in the } \mathrm{MCO} \text { at time step } \mathrm{J}+1 \text {, in liters at reference } \\
& \text { temperature and pressure } \\
& \mathrm{V}_{\mathrm{MCO}, \mathrm{1ot}, 3}=\text { volume of gas in the MCO at time step } \mathrm{J} \text {, in liters at reference temperature } \\
& \text { and pressure } \\
& \mathrm{dV}_{\mathrm{MCO}, \text { to }, J} / \mathrm{dt}=\text { rate of change in volume of gas in the MCO due to leakage to the MHM at } \\
& \text { time step } \mathrm{J} \text {, in liters per day at reference temperature and pressure } \\
& \mathbf{L}_{\mathrm{x}} \quad=\text { leak rate proportionality constant, } \mathrm{L} / \mathrm{d} \text { per } \mathrm{kPa} \\
& \mathbf{P}_{\mathrm{MCO}, \mathrm{J}}=\text { pressure inside the } \mathrm{MCO} \text { at time step } \mathrm{J} \text {, in } \mathrm{kPa} \\
& \mathrm{V}_{\mathrm{MCO}}=\text { volume of the } \mathrm{MCO} \text {, assumed to be } 500 \mathrm{~L} \\
& \mathrm{~T}_{\mathrm{MCO}, \mathrm{J}}=\text { temperature of gas in the } \mathrm{MCO} \text { at time step } \mathrm{J} \text {, in degrees kelvin } \\
& P_{\text {ref }} \quad=\text { reference pressure, } 101.3 \mathrm{kPa}(1 \mathrm{~atm}) \\
& \mathrm{T}_{\text {ref }} \quad=\text { reference temperature, } 298 \mathrm{~K}\left(25^{\circ} \mathrm{C}\right) \\
& \mathrm{C}_{\mathrm{MHM}, \mathrm{H}, \mathrm{J}+1}=\underset{\text { percent }}{\text { concentration of hydrogen or helium in the MHM at time step } \mathrm{J}+1 \text {, in }} \\
& \mathrm{C}_{\mathrm{MHM}, \mathrm{H}, \mathrm{J}}=\text { concentration of hydrogen or helium in the } \mathrm{MHM} \text { at time step } \mathrm{J} \text {, in percent } \\
& \mathrm{C}_{\mathrm{MEM}, \mathrm{Mir}, \mathrm{J}+1}=\text { concentration of air in the MHM at time step } \mathrm{J}+1 \text {, in percent } \\
& \mathrm{C}_{\mathrm{MHM}, \text { air, }}=\text { concentration of air in the MHM at time step J, in percent } \\
& \mathrm{V}_{\mathrm{MHM}}=\text { free volume of the MHM with an MCO inside, assumed to be } 1,170 \mathrm{~L} \\
& \mathrm{C}_{\mathrm{MCO}, \mathrm{Hx}}=\text { concentration of hydrogen or helium in the } \mathrm{MCO} \text {, in percent. Note that }
\end{aligned}
$$


$\mathrm{C}_{\mathrm{CSB}, \text { air }}=$ concentration of air at the CSB, assumed to be $100 \%$ ( $21 \%$ oxygen and $79 \%$ nitrogen)

$d V_{\mathrm{air}} / \mathrm{dt} \quad=$ rate at which air enters and leaves the MHM due to natural circulation, in liters per day at reference temperature and pressure

$\mathrm{P}_{\mathrm{MHM}}=$ pressure inside the MHM, assumed to be $101.3 \mathrm{kPa}$

$\mathrm{T}_{\mathrm{MHM}}=$ temperature inside the MHM, assumed to be $303 \mathrm{~K}\left(30^{\circ} \mathrm{C}\right)$.

The hydrogen concentration in the MHM rises to a peak value determined by the relationship between hydrogen addition and hydrogen removal. Hydrogen addition is characterized by the assumed leak rate from the MCO to the MHM. Hydrogen removal is characterized by the assumed natural circulation rate from the MHM to the environment. Table 5-4 summarizes reasonable combinations that were used with the above model.

Table 5-4. Peak Hydrogen Concentration for Various Add/Removal Factors.

\begin{tabular}{|c|c|c|c|}
\hline \multirow{2}{*}{$\begin{array}{c}\text { MHM natural } \\
\text { circulation per day }\end{array}$} & \multicolumn{3}{|c|}{ MCO leakage factor } \\
\cline { 2 - 4 } & 1,000 & 3,000 & 10,000 \\
\hline $100 \%$ & $1.07 \%$ in $4.0 \mathrm{~d}$ & $2.86 \%$ in $3.0 \mathrm{~d}$ & $\begin{array}{c}7.33 \% \text { in } 2.0 \mathrm{~d} \\
(4 \% \text { in } 1 \mathrm{lh})\end{array}$ \\
\hline $30 \%$ & $3.12 \%$ in $9.8 \mathrm{~d}$ & $\begin{array}{c}7.33 \% \text { in } 6.8 \mathrm{~d} \\
(4 \% \text { in } 37 \mathrm{~h})\end{array}$ & $\begin{array}{c}15.38 \% \text { in } 4.2 \mathrm{~d} \\
(4 \% \text { in } 10 \mathrm{~h})\end{array}$ \\
\hline $10 \%$ & $7.33 \%$ in $20.5 \mathrm{~d}$ & $\begin{array}{c}14.54 \% \text { in } 13.3 \mathrm{~d} \\
(4 \% \text { in } 31 \mathrm{~h})\end{array}$ & $\begin{array}{c}24.81 \% \text { in } 7.6 \mathrm{~d} \\
(4 \% \text { in } 9 \mathrm{~h})\end{array}$ \\
\hline
\end{tabular}

The MHM natural circulation rate is the fraction of air replaced per day. The MCO leakage factor times $1 \mathrm{E}-05 \mathrm{~cm}^{3} / \mathrm{s}$ is the leak rate at reference conditions. The percents shown are the peak hydrogen concentration at the time indicated. Where the peak is greater than $4 \%$, the time needed to exceed $4 \%$ is shown in parentheses.

$\mathrm{MCO}=$ multi-canister overpack

$\mathrm{MHM}=$ multi-canister overpack handling machine.

Higher leak rates and lower natural circulation rates are needed to reach flammable concentrations in the MHM. The case with a leakage factor of 10,000 and a natural circulation rate of $30 \%$ per day is shown in Figure 5-9. The MCO leakage corresponds to $0.1 \mathrm{~cm}^{3} / \mathrm{s}$ $(8.64 \mathrm{~L} / \mathrm{d})$ at reference conditions. It is assumed that the MHM is filled with air initially to provide the oxygen. Figure 5-9 shows the concentrations of oxygen and hydrogen in the MHM following the start of the leak from the MCO. From the graph, the hydrogen concentration exceeds the lower flammability limit after 0.4 days. The peak hydrogen concentration is $15.38 \%$, but this is not reached until 4.2 days after the start of the leak. 
Thirty hours after the start of the leak, the hydrogen concentration in the MHM would be $10 \%$. Thus, the mass of hydrogen present would be $9.6 \mathrm{~g}$, which is equivalent to $274 \mathrm{~g}$ of TNT. Again, the damage from hydrogen is lower due to the greater volume affected and the slower rate of combustion. The adiabatic flame temperature is $1,370 \mathrm{~K}\left(1,100^{\circ} \mathrm{C}\right)$, which leads to a maximum pressure of $436 \mathrm{kPa}\left(48 \mathrm{lb} / \mathrm{in}^{2}\right.$ gauge).

A hydrogen explosion in the MHM would damage the MHM due to the transitory high pressures. Because the MCO would not be damaged, the only available source of radioactivity is the HEPA filter units on the MHM turret. These could fill with the hydrogen-air mixture and be affected by the deflagration. For personnel protection reasons, the pair would read less than $50 \mathrm{mR} / \mathrm{h}$ on contact. Thus, the worst-case explosion near them would have consequences no worse than the rupture of the containment tent exhauster during MCO venting. The potential for personnel injury exists because personnel are normally located near the MHM turret to operate the MHM.

\subsubsection{Fydrogen Explosion During Interim Storage}

While an MCO is inside a storage tube at the CSB, an abnormal leakage rate could lead to flammable concentrations of hydrogen and air in the storage tube. The same equations derived to model the hydrogen accumulation in the MHM apply to the storage tube with the exception of differences in three of the input parameters. First, the storage tube with a single, mechanically sealed MCO has a free volume of about $2,890 \mathrm{~L}$. Second, the temperature of the air in the storage tube is assumed to be $35^{\circ} \mathrm{C}$. Third, the natural ventilation rate for the storage tube comes from the value for volumetric changes due to barometric pressure variations during the year (WHC-EP-0651). WHC-EP-0651, Barometric Pressure Variations, gives the following value for this rate. Note that the MHM subscript is used to be consistent with the formulas in the previous section.

$$
\mathrm{dV}_{\mathrm{dir}} / \mathrm{dt} / \mathrm{V}_{\mathrm{MHTM}}=1.69 \text { per year }=0.463 \% \text { per day }
$$

As with the MFM, it will be assumed that the storage tube is initially filled with air so that oxygen is present to react with the hydrogen leaking from the MCO. Because the ventilation rate is fixed, higher leak rates lead to higher peak concentrations of hydrogen in the storage tube. A summary of peak concentrations and times to reach those concentrations are shown in Table 5-5.

The case with a leakage factor of 10,000 is shown in Figure 5-10. The MCO leakage corresponds to $0.1 \mathrm{~cm}^{3} / \mathrm{s}(8.64 \mathrm{~L} / \mathrm{d})$ at reference conditions. Figure $5-10$ shows the concentrations of oxygen and hydrogen in the storage tube following the start of the leak from the MCO. From the graph, the hydrogen concentration exceeds the lower flammability limit after about 23 hours. The peak hydrogen concentration is $25.9 \%$, but this is not reached until 37 days. 
Table 5-5. Peak Storage Tube Concentrations for Various Multi-Canister Overpack Leak Rates.

\begin{tabular}{|c|c|c|c|}
\hline $\begin{array}{c}\text { MCO leakage } \\
\text { factor }\end{array}$ & $\begin{array}{c}\text { Peak hydrogen } \\
\text { concentration } \\
(\%)\end{array}$ & $\begin{array}{c}\text { Time to reach } \\
\text { peak hydrogen } \\
\text { (days) }\end{array}$ & $\begin{array}{c}\text { Time to exceed } \\
\text { 4\% hydrogen } \\
\text { (days) }\end{array}$ \\
\hline 1,000 & 16.1 & 124 & 9.6 \\
\hline 3,000 & 21.2 & 71 & 3.1 \\
\hline 10,000 & 25.9 & 37 & 0.9 \\
\hline
\end{tabular}

The MCO leakage factor times $\mathrm{IE}-05 \mathrm{~cm}^{3} / \mathrm{s}$ is the leak rate at reference conditions.

$\mathrm{MCO}=$ multi-canister overpack

If the hydrogen concentration in the storage tube were $20 \%$ at the time of the explosion, then the mass of hydrogen present would be $47 \mathrm{~g}$, which is equivalent to $1,350 \mathrm{~g}$ of TNT. Again, the damage from hydrogen would be lower due to the greater volume affected and the slower rate of combustion. The adiabatic flame temperature is $2,320 \mathrm{~K}$, which leads to a maximum pressure of $690 \mathrm{kPa}$ ( $85 \mathrm{lb} / \mathrm{in}^{2}$ gauge). The peak pressure is reached in about 13 milliseconds. Because the storage tube plug has a surface area of $0.37 \mathrm{~m}^{2}$ and a mass of $2,406 \mathrm{~kg}$, the speed of the plug after the explosion is $1.1 \mathrm{~m} / \mathrm{s}$. Under the influence of earth's gravity the plug would rise about $6.6 \mathrm{~cm}$. Thus, a hydrogen explosion in the storage tube could barely lift the storage tube plug. Note that the hydrogen concentrations are high enough that shock waves can be formed. The effect of this phenomenon is to possibly double the peak pressures (SFPE 1992). No radioactive releases are expected from this accident because the MCO pressure boundary should remain intact, and the storage tubes are assumed to have very little surface contamination.

With two MCOs in a storage tube the volume of air is reduced to $1,530 \mathrm{~L}$. The reduced air volume means that less hydrogen needs to leak from an $\mathrm{MCO}$ to reach flammable concentrations. However, the MCOs placed in the tube are sealed by welding on a cover cap. The leak rate criteria for these MCOs is $1 \times 10^{-7} \mathrm{~cm}^{3} / \mathrm{s}$. If one bounding case MCO has a leak rate 30,000 times this criteria, then the hydrogen concentration reaches a flammable concentration of $4 \%$ in 16 days. The assumed MCO leak rate corresponds to $0.003 \mathrm{~cm}^{3} / \mathrm{s}$ at reference conditions.

\subsubsection{Hydrogen Explosion During Multi-Canister Overpack Sampling}

To determine the composition of gases in an $\mathrm{MCO}$, selected MCOs are moved from the storage tubes to the sampling/weld station for analysis. A sampling hood is placed over the MCO. The hood is connected to the HEPA filtered exhaust system and the flow rate through the hood is between $47 \mathrm{~L} / \mathrm{s}$ and $118 \mathrm{~L} / \mathrm{s}$. Gas is vented from the MCO via a sampling line attached to the $\mathrm{MCO}$. If this connection were to fail, hydrogen and helium in the MCO would be vented to the hood and the exhauster. 
The mathematical representation of the composition of the gas in the sample hood follows. It is assumed that the flow rate from the $\mathrm{MCO}$ is proportional to the pressure of the $\mathrm{MCO}$, as discussed in Section 5.3.1.4. The initial flow rate from the leak is an input to control hydrogen accumulation in the hood. A spreadsheet was prepared to implement this model. Note that all volumes have been converted to reference temperature and pressure conditions.

Approximation for the $\mathrm{MCQ}$ :

$$
\begin{aligned}
& V_{M C O, t o t, J+1}=V_{M C O, t o t, J}-d V_{M C O, t o t, J} \\
& \mathrm{dV}_{\mathrm{MCO}, \mathrm{tot}, \mathrm{J}} / \mathrm{dt}=\left(\mathrm{F}_{0}\right)\left(\mathrm{V}_{\mathrm{MCO}, \mathrm{tot}, \mathrm{J}}\right) /\left(\mathrm{V}_{\mathrm{MCO}, \mathrm{to}, 0}\right)
\end{aligned}
$$

Approximation for the Sample Hood:

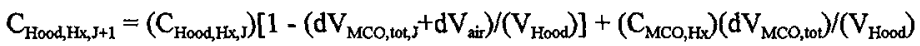

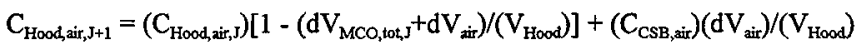

where

$$
\begin{aligned}
& \mathrm{V}_{\mathrm{MCO}, \mathrm{toh} \mathrm{J}+1}=\text { volume of gas in the } \mathrm{MCO} \text { at time step } \mathrm{J}+1 \text {, in liters at reference } \\
& \text { temperature and pressure } \\
& \mathrm{V}_{\mathrm{MCO}, \mathrm{tos} \mathrm{J}}=\text { volume of gas in the } \mathrm{MCO} \text { at time step } \mathrm{J} \text {, in liters at reference temperature } \\
& \text { and pressure } \\
& \mathrm{dV}_{\mathrm{MCO}, \text { tot } \mathrm{J}} / \mathrm{dt}=\text { rate of change in volume of both hydrogen and helium in the } \mathrm{MCO} \text { as it } \\
& \text { vents to the hood at time step } \mathrm{J} \text {, in } \mathrm{L} / \mathrm{s} \text { at reference temperature and } \\
& \text { pressure } \\
& \mathrm{F}_{0}=\text { initial flow rate from the MCO to the hood, in } \mathrm{L} / \mathrm{s} \\
& \mathrm{C}_{\mathrm{Hood}, \mathrm{H} x \mathrm{~J}+1}=\begin{array}{c}
\text { concentration of hydrogen or helium in the hood at time step } \mathrm{J}+1 \text {, in } \\
\text { percent }
\end{array} \\
& \mathrm{C}_{\mathrm{Hood}, \mathrm{H} \times \mathrm{J}}=\text { concentration of hydrogen or helium in the hood at time step } \mathrm{J} \text {, in percent } \\
& \mathrm{C}_{\mathrm{Hood}, \text { air }, \mathrm{Y}+\mathrm{1}}=\text { concentration of air in the hood at time step } \mathrm{J}+1 \text {, in percent } \\
& \mathrm{C}_{\text {Hood,air, } \mathrm{J}}=\text { concentration of air in the hood at time step } \mathrm{J} \text {, in percent } \\
& \mathrm{V}_{\text {hood }}=\text { volume of air in the hood, assumed to be } 600 \mathrm{~L} \text {, based on approximate } \\
& \text { dimensions of } 30 \text { in. by } 37.5 \text { in. by } 32.5 \text { in. }
\end{aligned}
$$


$\mathrm{C}_{\mathrm{MCO}, \mathrm{Hx}}=$ concentration of hydrogen or helium in the $\mathrm{MCO}$, in percent. Note that this does not change with time because there is no gas production during the event and the gas leakage is not enhanced by diffusion effects.

$\mathrm{C}_{\mathrm{CSB}, \text { air }}=$ concentration of air at the CSB, assumed to be $100 \%(21 \%$ oxygen and $79 \%$ nitrogen)

$\mathrm{dV}_{\mathrm{air}} \mathrm{dt}=$ rate at which air enters and leaves the hood due to operation of the hood exhauster, in $\mathrm{L} / \mathrm{s}$ at reference temperature and pressure.

To simplify calculations, the temperature of the gas in the hood is $25^{\circ} \mathrm{C}$, which is also the reference temperature. The ventilation rate for the hood is assumed to be $47 \mathrm{~L} / \mathrm{s}\left(100 \mathrm{ft}^{3} / \mathrm{min}\right)$ to minimize the hydrogen removal rate. The initial flow rate from the MCO into the hood is assumed to be $20 \mathrm{~L} / \mathrm{s}\left(42 \mathrm{ft}^{3} / \mathrm{min}\right)$. From the equation for choked flow through an orifice that follows, there must be a hole with a cross-sectional area of $6.05 \mathrm{~mm}^{2}\left(0.0094 \mathrm{in}^{2}\right)$ to produce this flow rate. Of course, higher flow rates will lead to greater hydrogen concentrations. Note that when the MCO flow rate exceeds $71 \mathrm{~L} / \mathrm{s}\left(150 \mathrm{ft}^{3} / \mathrm{min}\right)$ then the hood exhaust capacity is exceeded and the above equations do not apply. The excess gas (air, hydrogen and helium) is being forced out of the hood. Flow rates that are lower than the assumed value lead to lower hydrogen concentrations. The value chosen simply illustrates a flow rate that produces flammable mixtures in the hood.

$$
\dot{Q}_{\text {choke }}=C_{\text {dis }} A P_{M C O} \sqrt{\frac{\gamma g M}{\mathrm{RT}_{M C O}}\left(\frac{2}{\gamma+1}\right)^{(\gamma+1) /(\gamma-1)}}
$$

where

$Q_{\text {choke }}=$ mass flow rate out the hole, in $1 \mathrm{bm} / \mathrm{s}$

$\mathrm{C}_{\mathrm{dis}}=$ discharge coefficient, which is assumed to be 1.0

A $=$ cross-sectional area of the hole, in square inches

$\mathrm{g}=$ conversion factor, $32.17 \mathrm{lbm}-\mathrm{f} / \mathrm{s}^{2} / \mathrm{lbf}$

$\mathrm{M}=$ average molecular weight of the escaping gas, $2.67 \mathrm{lbm} / \mathrm{bb}-\mathrm{mole}$

$\mathrm{R}=$ ideal gas constant, $1,545 \mathrm{ft}-\mathrm{lbf} / \mathrm{b}-\mathrm{mole} /{ }^{\circ} \mathrm{R}$

$\mathrm{T}_{\mathrm{MCO}}=$ absolute temperature of the gas in the $\mathrm{MCO}, 627^{\circ} \mathrm{R}\left(75^{\circ} \mathrm{C}\right)$

$\mathbf{P}_{\mathrm{MCO}}=$ absolute pressure of the gas in the $\mathrm{MCO}, 78 \mathrm{lbf} / \mathrm{in}^{2}$ 
$\gamma \quad=$ the ratio of the heat capacities at constant pressure and volume for the hydrogenhelium mixture. For monatomic gases like helium, $\gamma$ is 1.67 , while for diatomic gases like hydrogen and air, $\gamma$ is 1.40 . The weighted average $\gamma$ was computed for the hydrogen-helium mixture using the number of moles of each as the weighting factor, giving a value of 1,49 .

Under the above conditions, the peak hydrogen concentration in the hood is $16.7 \%$, which is reached in 27 seconds. The lower flammability limit (4\% hydrogen) is reached in 2.0 seconds. Notice the time scale is now in seconds rather than days. Figure 5-11 shows the concentrations of oxygen and hydrogen in the weld/sampling hood following the start of the release from the MCO. Note that the time scale on this graph is seconds.

If the hydrogen concentration in the weld/sampling hood was $10 \%$ at the time of the explosion then the hood would contain $4.9 \mathrm{~g}$ of hydrogen, which releases a thermal energy equivalent to $140 \mathrm{~g}$ of TNT. Again, the damage from hydrogen is lower due to the greater volume affected and the slower rate of combustion. The adiabatic flame temperature is $1,370 \mathrm{~K}$, which leads to a maximum pressure of $442 \mathrm{kPa}\left(49 \mathrm{lb} / \mathrm{in}^{2}\right.$ gauge). This pressure is high enough to damage the hood and injure any personnel nearby. The potential for personnel injury exists because personnel are normally located near the sample hood during sampling operations.

To quantify the potential hazard to personnel, consider the effect of the explosion on the viewing window in front of the operator. Using the viewing window dimensions of $30 \mathrm{in}$. wide by $18 \mathrm{in}$. tall, the peak pressure increase of $49 \mathrm{lb} / \mathrm{in}^{2}$ applies a force of $26,700 \mathrm{lb}$ to the viewing window. Assuming the window is 0.5 in. thick and has a density of $1,100 \mathrm{~kg} / \mathrm{m}^{3}$, then its mass is $4.87 \mathrm{~kg}(10.7 \mathrm{lb})$. The peak pressure is reached in 4.4 milli-seconds using the method presented in Section 5.3.1.5. If no energy is lost to breaking the window free of its mounts, then the speed of the window is $106 \mathrm{~m} / \mathrm{s}(237 \mathrm{mi} / \mathrm{h})$. The impact with the operator will probably cause a fatality. If half the energy were needed to free the window, the speed would still be $71 \%$ of the maximum. Thus, there is a real possibility of serious injury or death from an explosion in the sample hood.

In addition to personnel injury, the hydrogen explosion in the sample hood may break the sample line, resulting in a rapid depressurizing of the MCO. Radioactive contamination in the MCO and sample hood HEPA filter can be released to the environment. The primary sources of radioactivity are (1) the HEPA filter near the sample hood, (2) the dry particulate matter suspended inside the $\mathrm{MCO}$ by the explosion, and (3) the entrained particulate matter resuspended and carried out with the gases leaving the MCO. Of these three, the third is estimated to provide nearly all of the activity released. Estimates of the amounts released are provided in Section 5.4.

\subsection{CONSEQUENCE ANALYSIS}

The downwind doses for each accident are computed in the following subsections. During cask venting, the containment tent HEPA filter is ruptured and releases a portion of its activity into the air. The hydrogen explosion in a storage tube is not expected to produce meaningful offsite consequences because there is no radioactive contamination nearby. The hydrogen 
explosion in the MHM will produce offsite doses no worse than the cask venting accident because the material at risk in the HEPA filters will be limited by the same criteria to minimize occupational exposure to personnel. The hydrogen explosion in the weld/sampling hood leads to much larger releases due to the depressurization of the MCO.

\subsubsection{Downwind Dose Calculation Methodology}

Inhalation doses to individuals located downwind of the CSB can be computed using the following equation (HNF-SD-SNF-TI-059). It assumed that the individuals are not evacuated during plume passage because of the short duration of the release.

$$
\mathrm{EDE}=\mathrm{M}_{\mathrm{air}}\left(\chi / \mathrm{Q}^{\prime}\right)(\mathrm{BR})(\mathrm{UD})
$$

where

$\mathrm{EDE}=$ the effective dose equivalent, in sieverts

$\mathbf{M}_{\text {air }}=$ the respirable quantity released into the air, in grams of uranium fuel

$\chi / Q^{\prime}=$ the air transport factor, $\mathrm{s} / \mathrm{m}^{3}$ (see Table 5-6)

$\mathrm{BR}=$ the average inhalation rate during the release, $3.33 \times 10^{-4} \mathrm{~m}^{3} / \mathrm{s}$

$\mathrm{UD}=$ the committed effective dose equivalent per unit gram inhaled, $4,380 \mathrm{~Sv} / \mathrm{g}$.

Table 5-6. Comparison of Doses with Risk Guidelines for Downwind Receptors from a Bounding Hydrogen Explosion During Cask Venting.

\begin{tabular}{|l|c|c|c|c|}
\hline \multirow{2}{*}{$\begin{array}{c}\text { Receptor location } \\
\text { (distance and direction) }\end{array}$} & \multirow{2}{*}{$\begin{array}{c}\text { Air transport } \\
\text { factor } \\
\left(\mathrm{s} / \mathrm{m}^{3}\right)\end{array}$} & \multicolumn{2}{|c|}{$\begin{array}{c}\text { Safety significant dose (CEDE }) \\
\text { rem (Sv) }\end{array}$} & \multirow{2}{*}{$\begin{array}{c}\text { Risk guideline } \\
\text { (Sv) }\end{array}$} \\
\cline { 3 - 5 } & & Unmitigated & Mitigated & \\
\hline $\begin{array}{l}\text { Onsite } \\
(100 \mathrm{~m} \mathrm{E})\end{array}$ & $3.41 \mathrm{E}-02$ & $\begin{array}{c}7.5 \mathrm{E}-02 \\
(7.5 \mathrm{E}-04)\end{array}$ & $\begin{array}{c}\text { Accident } \\
\text { prevented }\end{array}$ & $\begin{array}{c}1.0 \mathrm{E}+00 \\
(1.0 \mathrm{E}-02)\end{array}$ \\
\hline $\begin{array}{l}\text { Highway } 240 \\
(10,510 \mathrm{~m} \mathrm{~W})\end{array}$ & $2.01 \mathrm{E}-05$ & $\begin{array}{c}4.4 \mathrm{E}-05 \\
(4.4 \mathrm{E}-07)\end{array}$ & $\begin{array}{c}\text { Accident } \\
\text { prevented }\end{array}$ & NA \\
\hline $\begin{array}{l}\text { Hanford Site boundary } \\
(17,390 \mathrm{~m} \mathrm{E})\end{array}$ & $1.30 \mathrm{E}-05$ & $\begin{array}{c}2.8 \mathrm{E}-05 \\
(2.8 \mathrm{E}-07)\end{array}$ & NA & $\begin{array}{c}5.0 \mathrm{E}-01 \\
(5.0 \mathrm{E}-03)\end{array}$ \\
\hline
\end{tabular}
assumed.

Release is at ground level; release duration is less than 1 hour; no plume rise or plume meander has been

'Fifty-year committed effective dose equivalent from inhalation.

'Based on the anticipated frequency, 0.1 to 0.01 per year.

$\mathrm{CEDE}=$ committed effective dose equivalent.

NA = not applicable. 
The air transport factors are for adverse wind conditions. These conditions are exceeded only $0.5 \%$ of the hours in a year. The approach used in U.S. Nuclear Regulatory Commission (NRC) Regulatory Guide 1.145, Atmospheric Dispersion Models for Potential Accident Consequence Assessments at Nuclear Power Plants, was used to compute the 99.5 percentile air transport factors. Plume meander and building wake effects have not been included because the release duration following the explosion is only a few minutes. The releases are assumed to take place at ground level.

Hanford Site wind data collected at the Hanford Meteorological Station (HMS) for the years 1983 to 1991 was used in computing the air transport factors. The worst-case locations are used for each receptor. The onsite individuals are $100 \mathrm{~m}$ east and $10,510 \mathrm{~m}$ west of the CSB. The offsite individual is located 17,390 m east. As shown in HNF-SD-SNF-TI-059, A Discussion on the Methodology for Calculating Radiological and Toxicological Consequences for the Spent Nuclear Fuel Project at the Hanford Site, the computed air transport factors and unit dose factor lead to the minimum release amounts required to exceed the guidelines. The first guideline exceeded is for anticipated probability events at the onsite worker location $100 \mathrm{~m}$ east of the CSB. The minimum release amount needed to exceed the onsite guideline is $0.20 \mathrm{~g}$ of uranium fuel.

For hydrogen explosions near a HEPA filter, the bounding release fraction is 0.01 with a respirable fraction of 1.0 (DOE-HDBK-3010-94, Section 5.4.2.2). Applying this to the limiting release amount of $0.20 \mathrm{~g}$ uranium means the HEPA filter loading must not exceed $20 \mathrm{~g}$ of uranium fuel. For the $2 \mathrm{ft}$ by $2 \mathrm{ft}$ by $1 \mathrm{ft}$ filter, the contact reading at the side with a $1.5 \mathrm{~g}$ loading is about $50 \mathrm{mR} / \mathrm{h}$. Therefore, with $20 \mathrm{~g}$ of uranium the contact reading would be about $670 \mathrm{mR} / \mathrm{h}$. As long as each HEPA filter array has less than $20 \mathrm{~g}$ of uranium on it, any hydrogen explosions impacting the filter face will not exceed the downwind dose guidelines.

\subsubsection{Consequences of a Hydrogen Explosion After Venting the Cask}

During venting of the cask-MCO, the hydrogen concentration in the portable exhauster ductwork could be high enough to explode if ignited. Such an explosion would damage the ductwork and could injure personnel nearby. If the bounding case hydrogen were to explode in the exhauster HEPA filter instead, it would damage the housing and filter and lead to an environmental release of radioactivity.

For HEPA filter blasts, the bounding release fraction is 0.01 with a respirable fraction of 1.0 (DOE-HDBK-3010-94, Section 5.4.2.2). Assuming the filter is loaded with the amount of fuel $(1.5 \mathrm{~g})$ needed to give a reading of $50 \mathrm{mR} / \mathrm{h}$, then the airborne release would be $0.015 \mathrm{~g}$ fuel. Downwind dose results are shown in Table 5-6. The assumed release duration is less than one hour. The onsite and offsite dose guidelines are not exceeded. However, the potential for personnel injury may require safety-significant features to mitigate this accident. 


\subsubsection{Consequences of a Hydrogen Explosion During Multi-Canister Overpack Handling}

A hydrogen explosion in the MHM could damage the MHM due to high pressures. No environmental releases of radioactivity from the $\mathrm{MCO}$ are expected because the MCO would not be damaged. The only other sources of radioactivity are the HEPA filter units on the MHM turret. These filter units could fill with hydrogen air mixture and be part of the deflagration. For personnel protection reasons, each filter would be expected to read less than $50 \mathrm{mR} / \mathrm{h}$ on contact. Thus, the worst-case explosion near them would have consequences no worse than the rupture of the containment tent exhauster during MCO venting, shown in Table 5-6. The onsite and offsite dose guidelines would not be exceeded. The potential for personnel injury exists because personnel will be located near the MHM turret to operate it. Therefore, safety-significant features may be required to mitigate this accident.

\subsubsection{Consequences of a Hydrogen Explosion During Interim Storage}

The worst-case event in the storage tubes is when a tube containing a single MCO develops an explosive mixture of hydrogen and air. If this mixture were to detonate, it could seriously damage the storage tube and possibly lead to a misalignment that would prevent future removal of the MCO by normal means. Any environmental release of radioactivity due to resuspension of surface contamination would be very small and would lead to onsite and offsite doses well below the guidelines for anticipated events.

\subsubsection{Consequences of a Hydrogen Explosion During Multi-Canister Overpack Sampling}

A hydrogen explosion in the sample hood could damage the sample hood due to high pressures. Significant environmental releases of radioactivity from the MCO are expected because the sample line could also be damaged and allow the MCO to rapidly release its gaseous contents. Particulate matter contained in the MCO could be resuspended by the explosion and entrained in the exiting gases.

The bounding particulate inventory at the end of the CSB storage period is $66 \mathrm{~kg}$ (HNF-1527). For an MCO with two scrap baskets and three fuel baskets, the bounding releasable particulate is $34 \mathrm{~kg}$. Dose calculations for downwind receptors are based on the uranium fuel released. Assuming the particulate is all $\mathrm{UO}_{2}$, then the uranium fuel is $88 \%$ of the particulate mass, or $30 \mathrm{~kg}$.

For pressurized releases through a powder, the bounding release fraction is 0.005 with a respirable fraction of 0.4 (DOE-HDBK-3010-94, Section 4.4.2.3.2). Applying this to the projected bounding $\mathrm{MCO}$ particulate loading (HNF-1527) of $30 \mathrm{~kg} U$ leads to a value for $\mathrm{M}_{\text {air }}$ of $60 \mathrm{~g} \mathrm{U}$. This release fraction is considered bounding because it is based on experiments in which a pressurized gas was explosively released through a sample of powder. The present accident involves a pressurized release in which the gas surrounds the powder and is suddenly released. 
The assumed release fraction is clearly conservative because the MCO vent path does not travel through the particulate it contains.

The release of particulate matter suspended inside the MCO by the explosion is limited by the ability of gases to support particulate matter. The maximum respirable particulate loading is about $1 \mathrm{~g} / \mathrm{m}^{3}$. Because the MCO internal volume is about $0.5 \mathrm{~m}^{3}$, the bounding mass lofted inside the $\mathrm{MCO}$ is $0.5 \mathrm{~g}$. Because not all of this will exit the MCO and also because the mass estimated to be released by the blowdown of the $\mathrm{MCO}$ is much larger, this mass has been ignored as an insignificant contribution to the total release.

Resulting doses are shown on Table 5-7. The unmitigated case exceeds the onsite guideline by a considerable margin. In addition, death of an operator performing the sample connection is likely; therefore, safety-significant features are required to mitigate this accident.

Table 5-7. Comparison of Doses with Risk Guidelines for Downwind Receptors from a Bounding Hydrogen Explosion in the Sample Hood.

\begin{tabular}{|c|c|c|c|c|}
\hline \multirow{2}{*}{$\begin{array}{l}\text { Receptor location } \\
\text { (distance and direction) }\end{array}$} & \multirow{2}{*}{$\begin{array}{c}\text { Air transport } \\
\text { factor }^{\text {a }} \\
\left(\mathrm{s} / \mathrm{m}^{3}\right)\end{array}$} & \multicolumn{2}{|c|}{$\begin{array}{c}\text { Safety significant dose }\left(\mathrm{CEDE}^{\mathrm{b}}\right) \\
\text { rem }(\mathrm{Sv})\end{array}$} & \multirow{2}{*}{$\begin{array}{c}\text { Risk guideline } \\
\text { (Sv) }\end{array}$} \\
\hline & & Unmitigated & Mitigated & \\
\hline $\begin{array}{l}\text { Onsite } \\
(100 \mathrm{mE})\end{array}$ & 3.41 E-02 & $\begin{array}{c}3.0 E+02 \\
(3.0 E+00)\end{array}$ & $\begin{array}{l}\text { Accident } \\
\text { prevented }\end{array}$ & $\begin{array}{r}1.0 \mathrm{E}+00 \\
(1.0 \mathrm{E}-02)\end{array}$ \\
\hline $\begin{array}{l}\text { Highway } 240 \\
(10,510 \mathrm{~m} \mathrm{~W})\end{array}$ & $2.01 \mathrm{E}-05$ & $\begin{array}{c}1.8 \mathrm{E}-01 \\
(1.8 \mathrm{E}-03)\end{array}$ & $\begin{array}{l}\text { Accident } \\
\text { prevented }\end{array}$ & NA \\
\hline $\begin{array}{l}\text { Hanford Site boundary } \\
(17,390 \mathrm{~m} \mathrm{E})\end{array}$ & $1.30 \mathrm{E}-05$ & $\begin{array}{l}1.1 \mathrm{E}-01 \\
(1.1 \mathrm{E}-03)\end{array}$ & NA & $\begin{array}{c}5.0 \cdot \mathrm{E}-01 \\
(5.0 \mathrm{E}-03)\end{array}$ \\
\hline
\end{tabular}

Release is at ground level; release duration is less than 1 hour; no plume rise or plume meander has been assumed.

'Fifty-year committed effective dose equivalent from inhalation.

'Based on the anticipated frequency, 0.1 to 0.01 per year.

$\mathrm{CEDE}=$ committed effective dose equivalent.

NA $=$ not applicable.

\subsection{COMPARISON TO GUIDELINES}

Mitigation of these hydrogen explosions is discussed in the following subsections. For each scenario, mitigation reduces the likelihood that an explosive hydrogen mixture can be formed. If an explosive mixture of hydrogen and oxygen is not formed, then there are no dose or personal injury consequences for the scenario. 


\subsubsection{Mitigation of Hydrogen Explosions During Cask Venting}

Mitigation of a hydrogen explosion in the tent exhaust system begins with ensuring the MCO has met the leak rate requirement at CVDF prior to being transported to the CSB. If the leak rate meets the criteria, then the time needed to accumulate significant hydrogen in the cask is too long for a shipping delay to provide the necessary time.

Excessive hydrogen is prevented from building up in the cask before venting by ensuring there are no delays during transport between the CVDF and the CSB. Current design calls for venting within 4 days after sealing at the CVDF.

Preventing a hydrogen explosion in the tent exhaust system is based on preventing the formation of an explosive mixture of hydrogen and air in the ductwork. An explosive mixture of hydrogen and air is prevented by reducing the rate at which hydrogen enters the ductwork and ensuring that planned helium flow is present to dilute the hydrogen.

The consequences of an explosion in the HEPA filter are mitigated by ensuring the uranium fuel loading is less than $20 \mathrm{~g}$. Because the single HEPA filter is unlikely to be shielded and $20 \mathrm{~g}$ uranium fuel leads to excessive dose rates, this limit will easily be met by ALARA (as low as reasonably achievable) program controls.

\subsubsection{Mitigation of Hydrogen Explosions Inside the Multi-Canister Overpack Handling Machine}

Mitigation of a hydrogen explosion during MCO handling begins with ensuring the MCO meets the leak rate requirements and protecting the MHM from catastrophic failures and delays in repairing the ventilation system:

The MHM active ventilation system precludes any significant hydrogen buildup. The periodic use of this ventilation system is recommended in the event that an $\mathrm{MCO}$ is trapped in the MHM for any length of time.

The consequences of an explosion in the HEPA filters are mitigated by ensuring the total uranium fuel loading on both HEPA filters is less than $20 \mathrm{~g}$. Because the HEPA filters are unlikely to be shielded and $20 \mathrm{~g}$ uranium fuel leads to excessive dose rates on the MHM turret, this limit should easily be met by ALARA program controls.

\subsubsection{Mitigation of Hydrogen Explosions Inside Storage Tubes}

Mitigation of a hydrogen explosion during interim storage begins with ensuring the MCO meets the leak rate requirements prior to being placed in a storage tube. As long as the MCO leak rate meets the criteria, then natural barometric changes make it impossible to accumulate significant hydrogen in a storage tube. 


\subsubsection{Mitigation of Hydrogen Explosions During Multi-Canister Overpack Sampling}

Mitigation of a hydrogen explosion during MCO sampling requires protecting the hose connection to the MCO from major leaks. During the opening of the MCO sample port valve, the operator should measure the hydrogen concentration in the hood. Excessive concentrations would require immediate action, such as closing the sample port valve or evacuating the sampling/weld station.

Another way to prevent the explosion is to pressure check the sample line after it is connected to the MCO. Purging the line with helium would be necessary before making the connection to ensure no oxygen is forced into the MCO during the pressure test.

An alternate approach is to modify the weld/sampling hood design to use an airtight attachment to the MCO. The hood could then be filled with helium to displace air. The exhauster would still be needed to direct MCO gases through the HEPA filter. With an inert atmosphere surrounding the sample line, any hydrogen leaks would not lead to flammable mixtures inside the sample hood. Thus, the accident would be prevented.

The consequences of an explosion in the HEPA filters are mitigated by ensuring the total uranium fuel loading on all HEPA filters is less than $20 \mathrm{~g}$. Because the HEPA filters are unlikely to be shielded and $20 \mathrm{~g}$ uranium fuel leads to excessive dose rates near the sample hood, this limit should easily be met by ALARA program controls.

\subsection{SUMMARY OF SAFETY-CLASS STRUCTURES, SYSTEMS, AND COMPONENTS AND TECHNICAL SAFETY REQUIREMENT CONTROLS}

No safety-class structures, systems, and components (SSCs) are required to prevent hydrogen explosion design basis accident (WS-L-11) outside of the MCO. Under normal operating conditions, there is no external accumulation of flammable concentrations of hydrogen. Under abnormal or accident conditions, safety-significant equipment is required in order to ensure flammable concentrations of hydrogen external to the MCO and CSB systems are precluded. To prevent the bounding external hydrogen explosion in the sample hood, it is necessary to check the leak rate of the sample line before the MCO port valve is opened. The maximum allowable leak rate is based upon the bounding hydrogen concentration and air flow rate in the sample hood. If the air flow rate is greater than or equal to $5 \mathrm{ft}^{3} / \mathrm{min}$ in the sample hood and the sample line leak rate is less than $40 \mathrm{~cm}^{3} / \mathrm{s}$, then the hydrogen concentration in the hood will not exceed $1 \%$. The following are the specific safety SSCs and technical safety requirement (TSR) controls that prevent this event:

- Safety-significant SSCs

- $\quad$ MCO valve operator and sample line - Provides confinement of flammable hydrogen gas with the confinement boundary to below $40 \mathrm{~cm}^{3} / \mathrm{s}$ 


\section{SNF-3328 REV 0}

- $\quad$ Sampling hood exhaust system (hood; ducting; heating, ventilation, and air conditioning fan) - Provides air negative pressure and flow $\left(>5 \mathrm{ft}^{3} / \mathrm{min}\right)$ to dilute any flammable gas concentrations to below $1 \%(25 \%$ of the lower flammability limit)

- TSRs

- Verify minimum air flow rate for hydrogen gas dilution $\left(5 \mathrm{ft}^{3} / \mathrm{min}\right)$ in the hood

- Verify that the sample line and connection leaks less than $40 \mathrm{~cm}^{3} / \mathrm{s}$ by performing pressure test of sampling connections, operator, and hose assembly

- Independent verification of sampling connection assembly and performance of the pressure test of the sample assembly

- Limit the radionuclide inventory on the HEPA filter attached to the sampling hood exhaust system to less than $20 \mathrm{~g}$.

- Limit the radionuclide inventory on the HEPA filter attached to the sampling piping to less than $20 \mathrm{~g}$.

The SSCs and TSR controls designated to prevent the MCO external hydrogen explosion are summarized in Table 5-8. U.S. Nuclear Regulatory Commission important-to-safety category SSCs and defense-in-depth features also are included for each specific accident in Table 5-8.

The suite of safety SSCs and TSR controls necessary and sufficient to prevent the MCO external hydrogen explosion accidents do not address some of the other accidents in the same accident category. Table 5-8 also lists the safety SSCs and TSR controls needed to prevent or control these accidents. Because these accidents are substantially different in development and progression from the design basis accidents, each scenario and the corresponding controls are also described below.

The hydrogen explosion in the MHM (OA-J-06b, in the MHM) caused by hydrogen leakage from the $\mathrm{MCO}$ occurs during $\mathrm{MCO}$ handling. This accident scenario assumes that the MHM contains an MCO with a small leak (10,000 times the criteria). If the MHM is immobilized by a power failure or some other event and the ventilation system is off, the gas mixture in the MHM will become flammable in less than a day. Combustion of this hydrogen mixture would at most release activity accumulated on the MHM HEPA filters into the environment. Using the bounding release factor for explosions on HEPA filters, the onsite dose guidelines are met if the HEPA filter loading is less than $20 \mathrm{~g}$ of SNF. The corresponding exposure rate near the filter exceeds $600 \mathrm{mR} / \mathrm{h}$. The following are the specific safety features and controls that prevent or mitigate this event: 
Table 5-8. Summary of Safety Features Required to Mitigate the Consequences of a Multi-Canister Overpack External Hydrogen Explosion. (2 sheets)

\begin{tabular}{|c|c|c|c|c|}
\hline Accident & $\begin{array}{l}\text { Checklist } \\
\text { designator }\end{array}$ & General function & Safety features and safety classification ${ }^{b}$ & $\begin{array}{l}\text { NRC ITS } \\
\text { category }^{\text {b }}\end{array}$ \\
\hline \multicolumn{5}{|c|}{ Hydrogen deflagration } \\
\hline $\begin{array}{l}\text { Hydrogen } \\
\text { explosion in } \\
\text { the } \\
\text { sampling/ } \\
\text { weld station } \\
\text { hood } \\
\text { caused by } \\
\text { sample line } \\
\text { connection } \\
\text { failure } \\
\text { (DBA) }\end{array}$ & WS-L-11 & $\begin{array}{l}\text { Ensure sufficient } \\
\text { air flow in the } \\
\text { hood to dilute } \\
\text { quantities of } \\
\text { hydrogen gas } \\
\text { leaking from the } \\
\text { sample line or } \\
\text { connection to } \\
\text { below }<1 \% \\
\text { ( } 25 \% \text { of the } \\
\text { lower } \\
\text { flammability } \\
\text { limit) } \\
\text { Ensure that the } \\
\text { sample line } \\
\text { connection from } \\
\text { the sample valve } \\
\text { to the connecting } \\
\text { hose does not } \\
\text { leak }\end{array}$ & $\begin{array}{l}\text { Safety-significant SSCs: } \\
\text { - MCO valve operator and sample } \\
\text { Hampling hood exhaust system (hood, ducting, } \\
\text { HVAC fan) } \\
\text { TSRs: } \\
\text { Verify minimum air flow rate for hydrogen gas } \\
\left.\text { dilution ( } 5 \mathrm{f}^{3} / \mathrm{min}\right) \text { in the hood } \\
\text { Perform pressure test of sampling connections, } \\
\text { operator and hose assembly, including that the } \\
\text { sample line and connection leaks less than } \\
40 \mathrm{~cm}^{3} / \mathrm{s} \\
\text { Independent verification of sampling connection } \\
\text { assembly and performance of the pressure test } \\
\text { of the sample assembly } \\
\text { - Limit the radionuclide inventory on HEPA filter } \\
\text { attached to sampling hood exhaust system to } \\
20 \mathrm{~g} \\
\text { Limit the radionuclide inventory on HEPA filter } \\
\text { attached to sampling piping to } 20 \mathrm{~g}\end{array}$ & $\begin{array}{l}\text { NA } \\
\text { NA }\end{array}$ \\
\hline $\begin{array}{l}\text { Hydrogen } \\
\text { explosion in } \\
\text { the MHM } \\
\text { due to } \\
\text { hydrogen } \\
\text { leakage } \\
\text { from the } \\
\text { MCO }\end{array}$ & $\begin{array}{l}O A-J-06 b \\
\text { (in MFM) }\end{array}$ & $\begin{array}{l}\text { Mitigate the } \\
\text { quantity of } \\
\text { release to below } \\
\text { onsite } \\
\text { consequence } \\
\text { guidelines }\end{array}$ & $\begin{array}{l}\text { Assumption: } \\
\text { - Reliance on leak testing at the CVDF to ensure } \\
\text { that only MCOs that meet SNF Project criteria } \\
\text { on MCO leakage are shipped to the CSB } \\
\text { TSR: } \\
\text { - Surveillance to limit the radionuclide inventory } \\
\text { on the HEPA filter in the MHM to less than } \\
20 \mathrm{~g} \\
\text { Defense in depth: } \\
\text { Limit flow rate of vented gases so that when } \\
\text { mixed with air in the portable exhaust duct } \\
\text { work, the mixture is not flammable }\end{array}$ & \\
\hline
\end{tabular}


Table 5-8. Summary of Safety Features Required to Mitigate the Consequences of a Multi-Canister Overpack External Hydrogen Explosion. (2 sheets)

\begin{tabular}{|c|c|c|c|c|}
\hline Accident & $\begin{array}{c}\text { Checklist } \\
\text { designator }\end{array}$ & General function & Safety features and safety classification & \\
\hline
\end{tabular}

"Checklist designators are from HNF-SD-SNF-HIE-001, 1999, Canister Storage Building Hazard Analysis Report, Rev. 1, Fluor Daniel Hanford, Incorporated, Richland, Washington.

${ }^{b}$ Safety classification for DBA in this category. Safety classification or ITS category could be different for another DBA category.

$\mathrm{CSB}=$ Canister Storage Building.

$\mathrm{DBA}=$ design basis accident.

CVDF $=$ Cold Vacuum Drying Facility.

HEPA = high-efficiency particulate air (filter).

HVAC $=$ heating, ventilation, and air conditioning.

ITS $=$ important to safety.

$\mathrm{MCO}=$ muiti-canister overpack.

MHM = multi-canister overpack handling machine.

NA = not applicable to ITS category classification.

$\mathrm{NRC}=$ U.S. Nuclear Regulatory Commission.

SSC $=$ structure, system, and component.

SNF $=$ spent nuclear fuel.

$\mathrm{TSR}=$ technical safety requirement. 
- Assumption

- Reliance on leak testing at the CVDF to ensure that only MCOs that meet SNF Project criteria on MCO leakage are shipped to the CSB

- TSR

- Limit the radionuclide inventory on the HEPA filter in the MHM extract system to less than $20 \mathrm{~g}$.

\subsection{REFERENCES}

Crowl, D. A., and J. F. Louvar, 1990, Chemical Process Safety Fundamentals with Applications, Prentice Hall, Englewood Cliffs, New Jersey.

DOE-HDBK-3010-94, 1994, Airborne Release Fractions/Rates and Respirable Fractions/Rates for Nonreactor Nuclear Facilities, U.S. Department of Energy, Washington, D.C.

HNF-1523, 1997, K-Basins Particulate Water Content, Behaviour, and Impact, Rev. 0, Fluor Daniel Hanford, Incorporated, Richland, Washington.

HNF-1527, 1998, Estimates of Particulate Mass in Multi-Canister Overpacks, Rev. 1, Duke Engineering Services Hanford, Incorporated, Richland, Washington.

HNF-2155, 1998, Multi-Canister Overpack Combustible Gas Management Leak Test Acceptance Criteria, Rev. 0, Duke Engineering Services Hanford, Incorporated, Richland, Washington.

HNF-SD-SNF-HIE-001, 1998, Canister Storage Building Hazard Analysis Report, Rev. 1, Draft, Fluor Daniel Hanford, Incorporated, Richland, Washington.

HNF-SD-SNF-TI-015, 1998, Spent Nuclear Fuel Project Technical Databook, Rev. 5, Fluor Daniel Hanford, Incorporated, Richland, Washington.

HNF-SD-SNF-TI-059, 1998, A Discussion on the Methodology for Calculating Radiological and Toxicological Consequences for the Spent Nuclear Fuel Project at the Hanford Site, Rev. 1, Fluor Daniel Hanford, Incorporated, Richland, Washington.

HNF-SD-TP-SARP-017, 1998, Safety Analysis Report for Packaging (Onsite) Multicanister Overpack Cask, Rev. 1, Fluor Daniel Hanford, Incorporated, Richland, Washington.

NRC Regulatory Guide 1.145, 1982, Atmospheric Dispersion Models for Potential Accident Consequence Assessments at Nuclear Power Plants, Rev. 1, U.S. Nuclear Regulatory Commission, Washington, D.C. 
NUREG-1320, 1988, Nuclear Fuel Cycle Accident Analysis Handbook, U.S. Nuclear Regulatory Commission, Washington, D.C.

NUREG/CR-2726, 1983, Light Water Reactor Hydrogen Manual, Sandia National Laboratories, Albuquerque, New Mexico.

SFPE, 1992, SFPE Handbook of Fire Protection Engineering, Society of Fire Protection Engineers, Boston, Massachusetts.

SNF-2770, 1998, Cold Vacuum Drying Facility Design Basis Accident Analysis Documentation, Rev. 0, Fluor Daniel Hanford, Incorporated, Richland, Washington.

WHC-EP-0651, 1993, Barometric Pressure Variations, Westinghouse Hanford Company, Richland, Washington.

WHC-SD-WM-UM-030, 1995, ISO-PC Version 1.98-User's Guide, Rev. 0, Westinghouse Hanford Company, Richland, Washington.

Whitwell, J. C., and R. K. Toner, 1969, Conservation of Mass and Energy, Blaisdell Publishing Company, Waltham, Massachusetts. 
SNF-3328 REV 0

Figure 5-1. General Sequence for External Hydrogen Explosions.

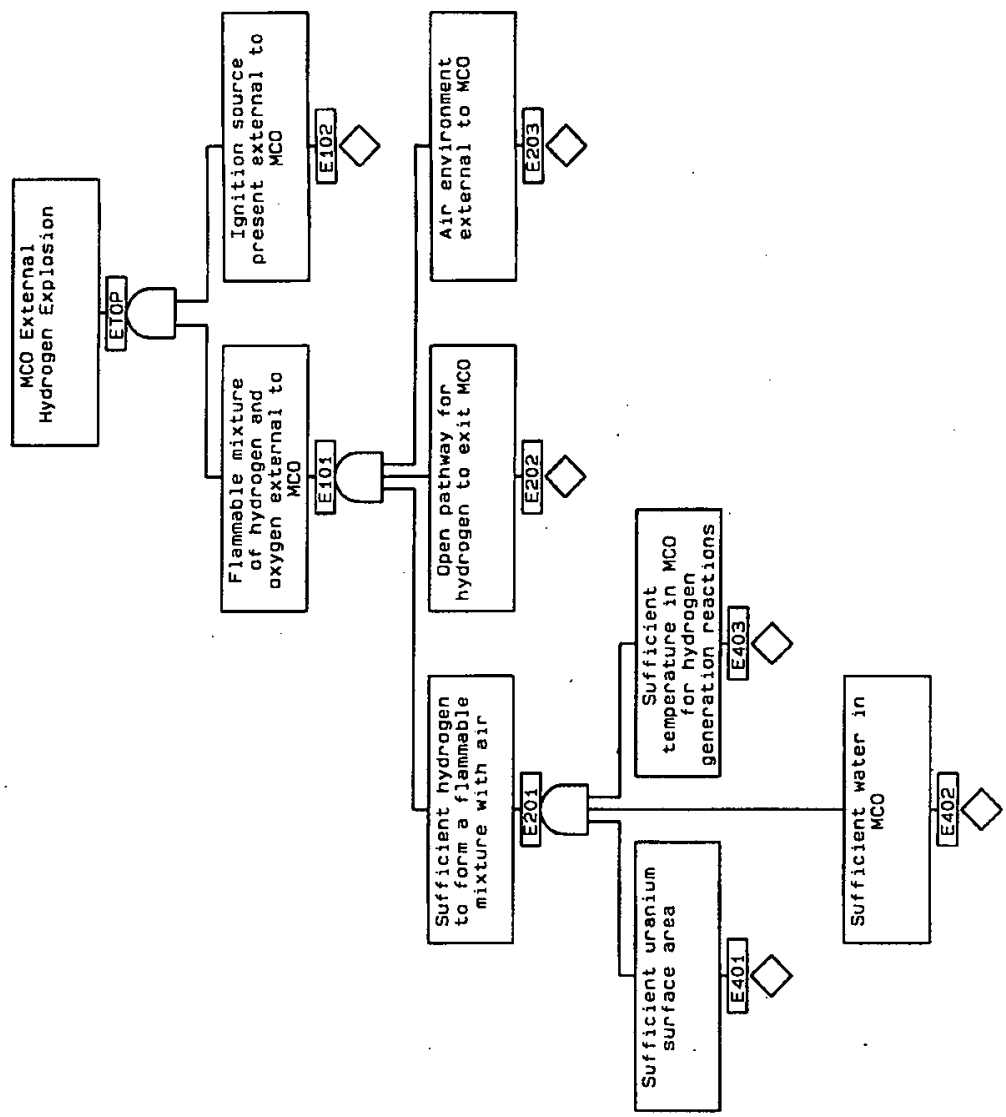


Figure 5-2. Hydrogen Explosion in the Confinement Tent Exhaust System.

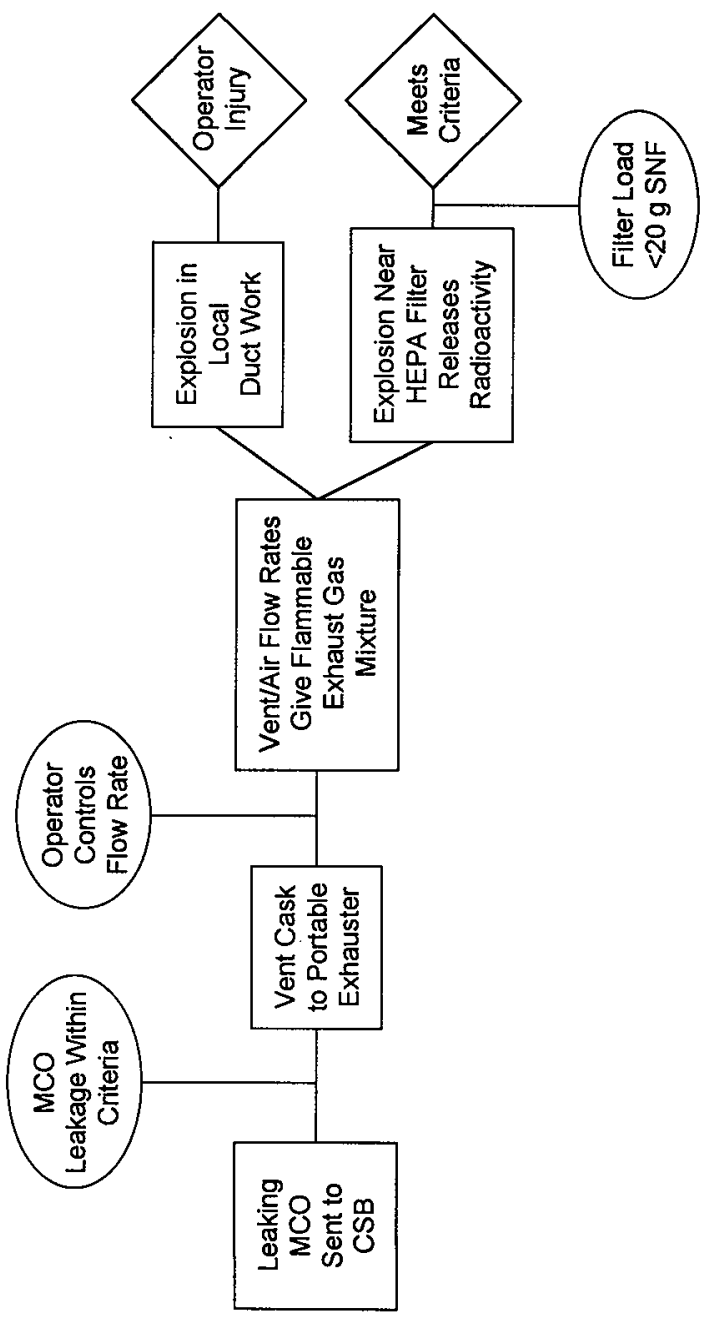


Figure 5-3. Hydrogen Explosion in the Multi-Canister Overpack Handling Machine and Mitigating Features.

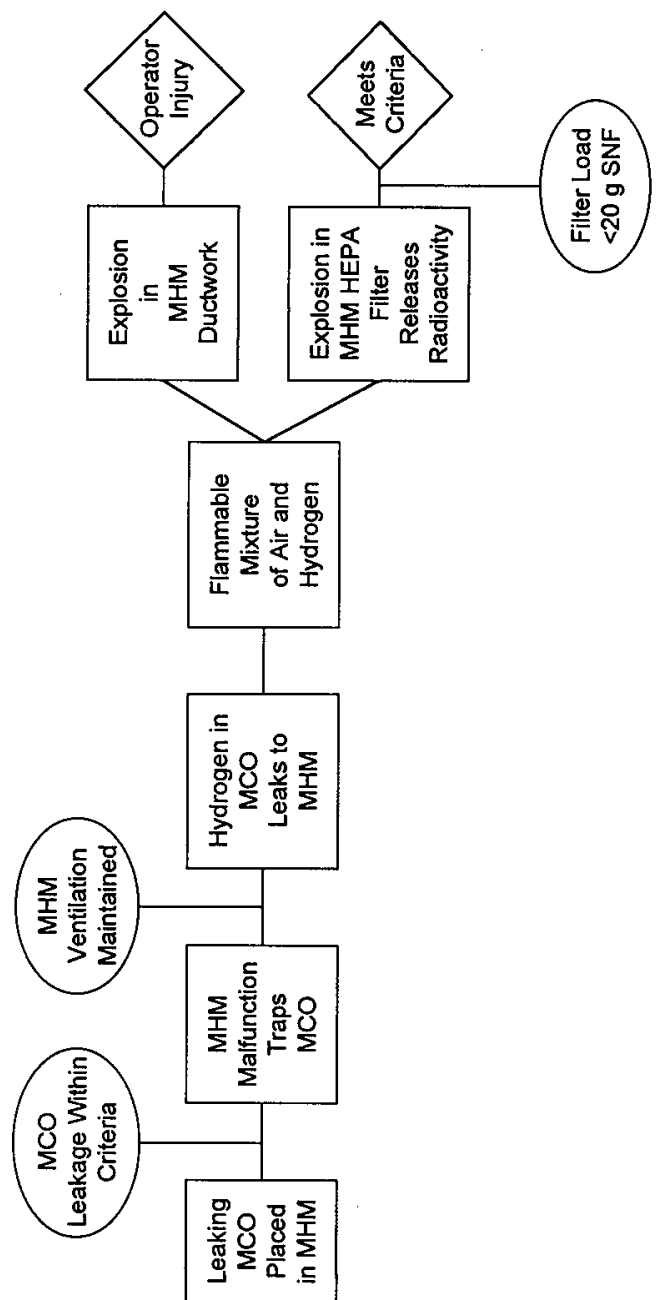


Figure 5-4. Hydrogen Explosion in a Storage Tube and Mitigating Features.

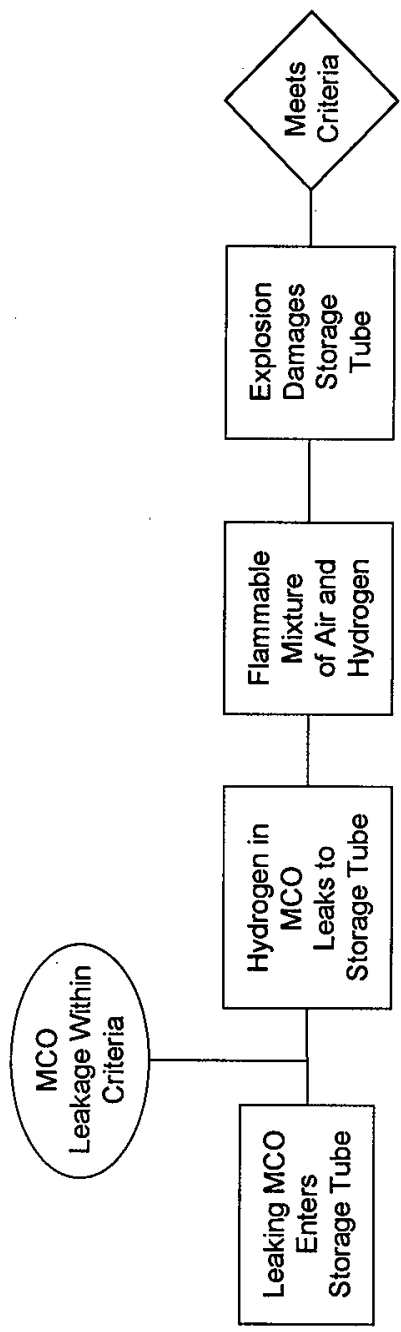




\section{SNF-3328 REV 0}

Figure 5-5. Hydrogen Explosion in the Sample Hood and Mitigating Features.

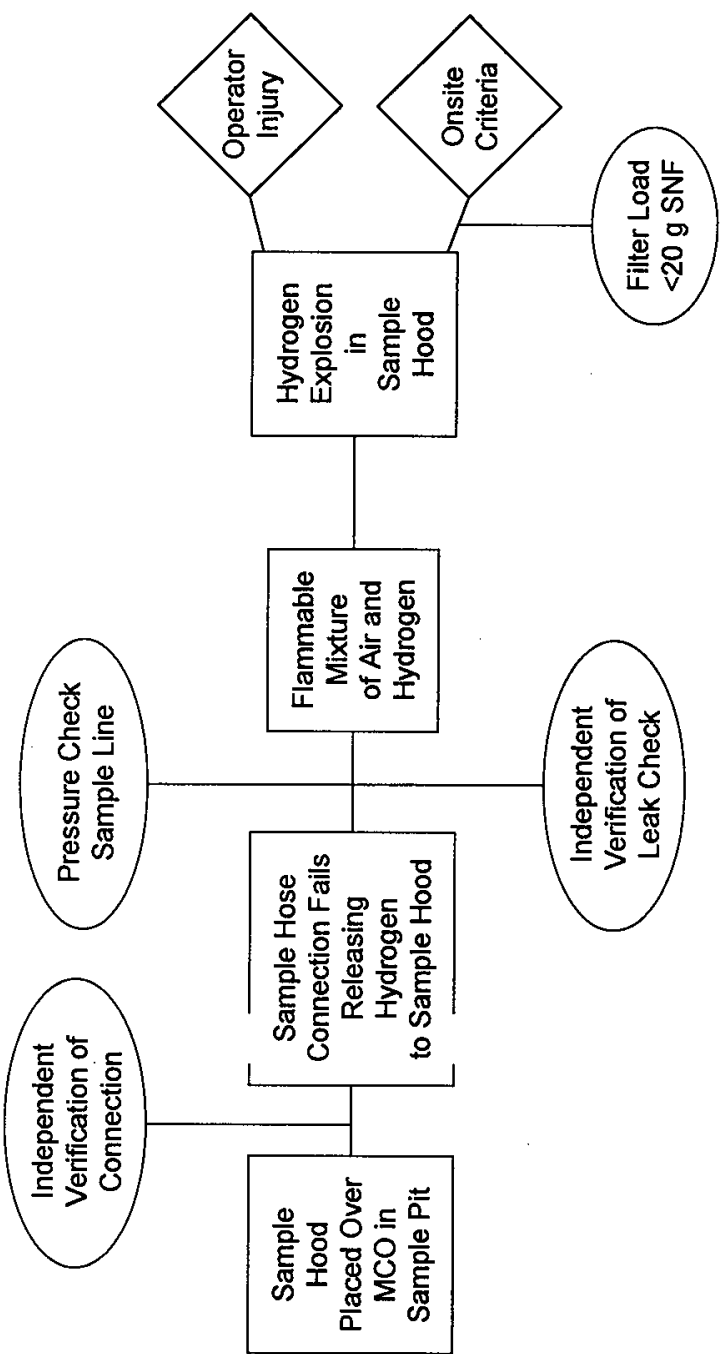


SNF-3328 REV 0

Figure 5-6. Fuel, Multi-Canister Overpack, and Cask Temperatures Enroute to Canister Storage Building.

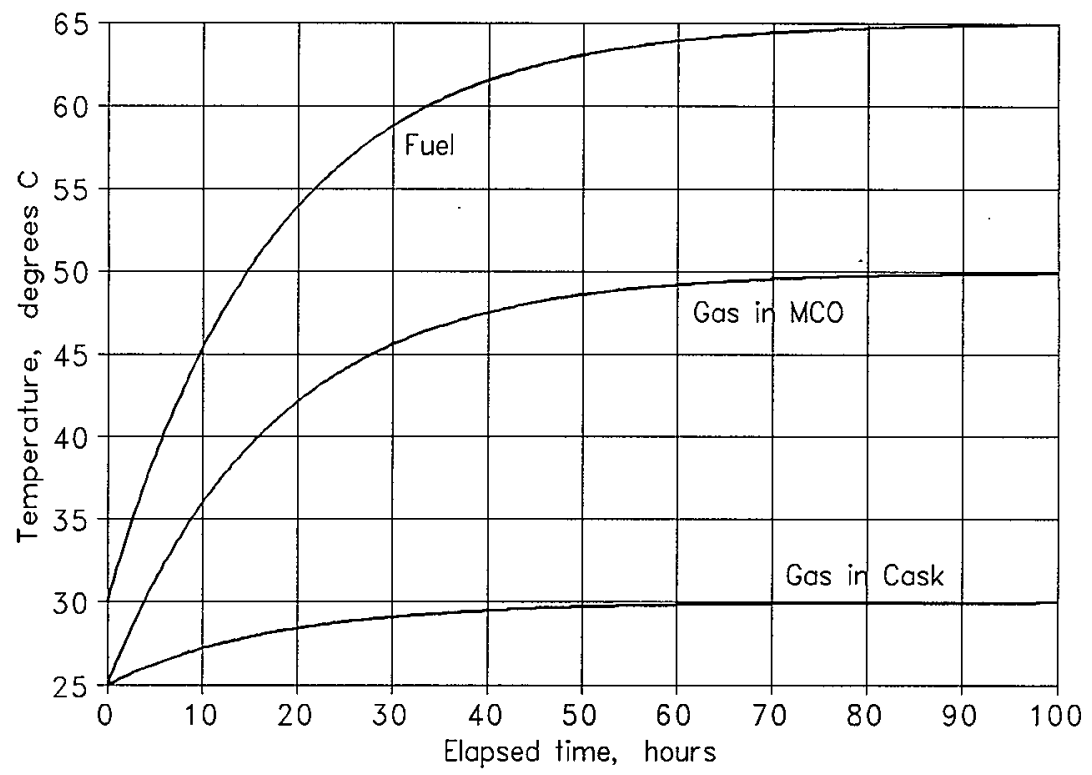


Figure 5-7. Multi-Canister Overpack and Cask Pressures Enroute to Canister Storage Building.

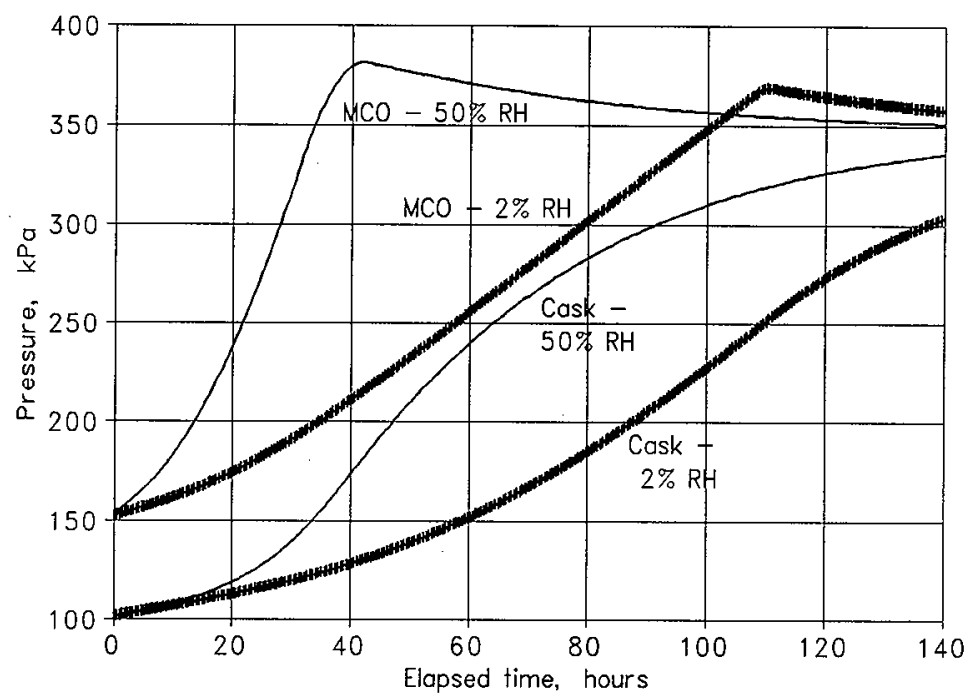


Figure 5-8. Hydrogen Concentrations in the Cask Enroute to Canister Storage Building.

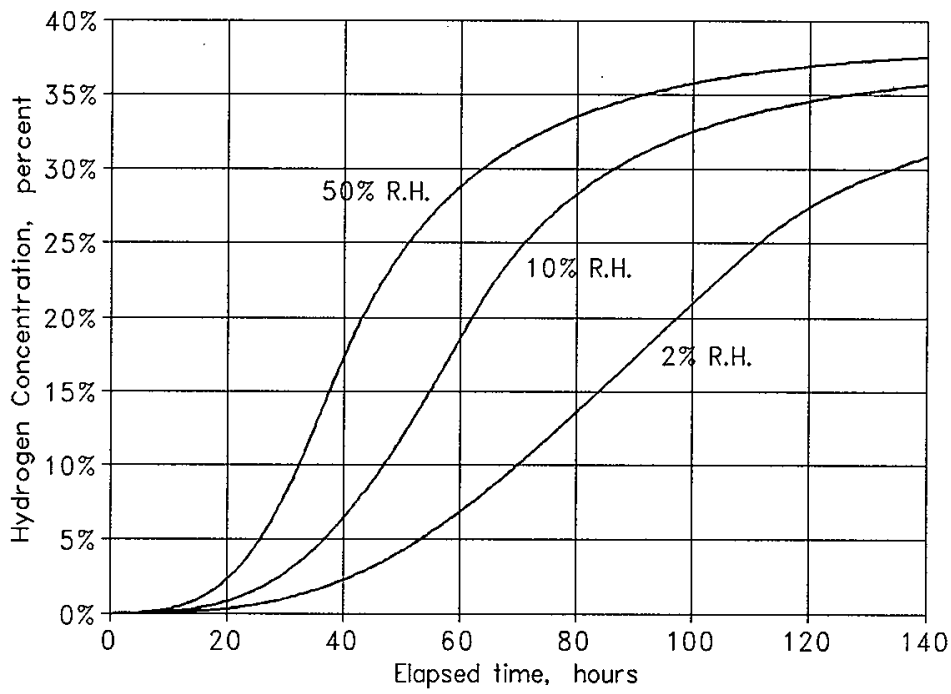




\section{SNF-3328 REV 0}

Figure 5-9. Multi-Canister Overpack Handling Machine Gas Concentrations with No Ventilation.

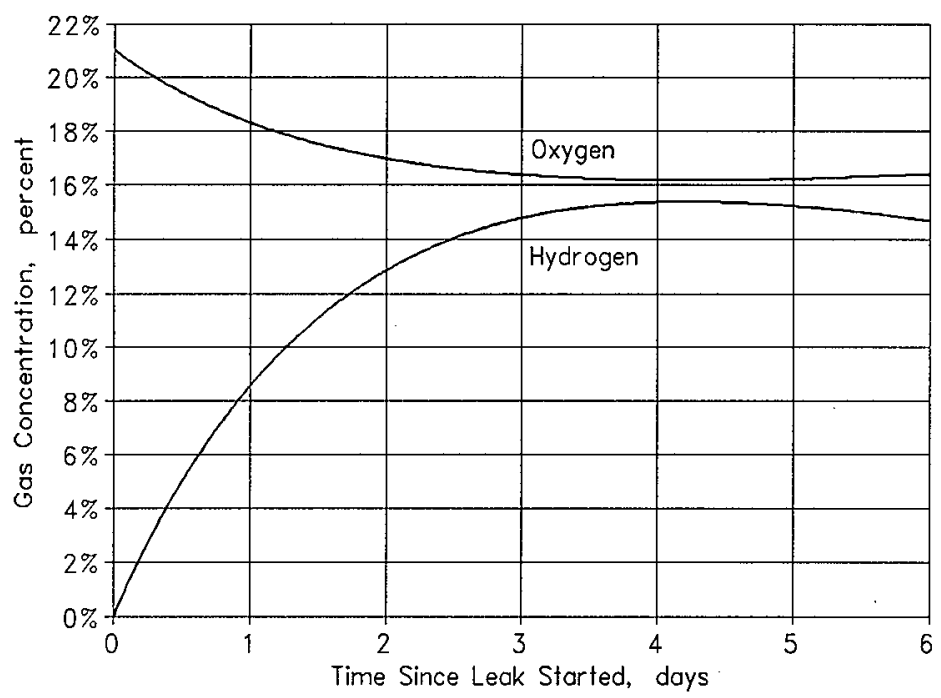


Figure 5-10. Gas Concentrations in a Storage Tube with One Multi-Canister Overpack.

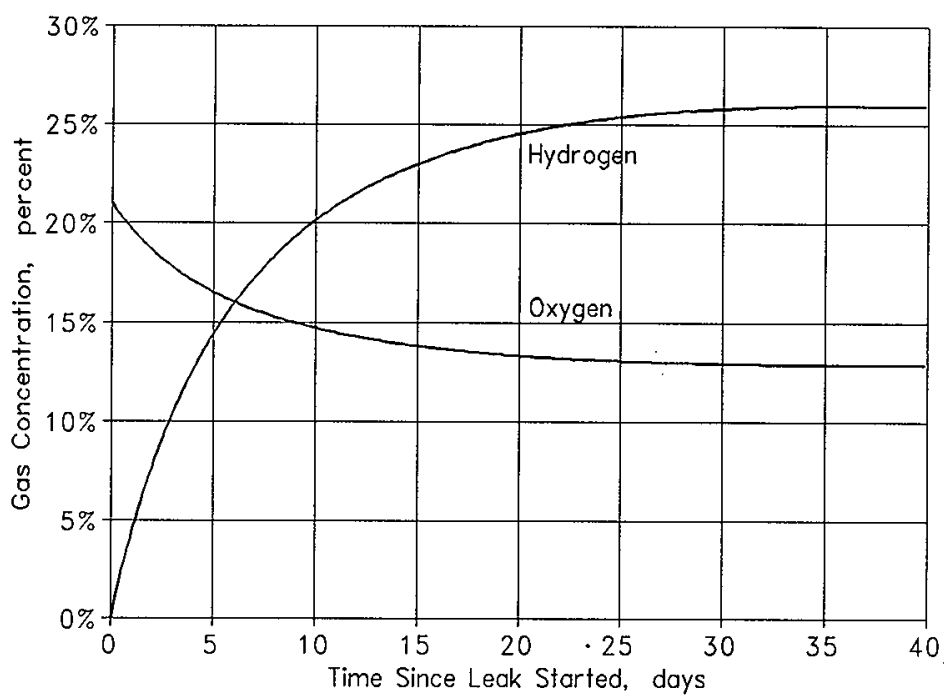


SNF-3328 REV 0

Figure 5-11. Gas Concentrations in the Sample Hood.

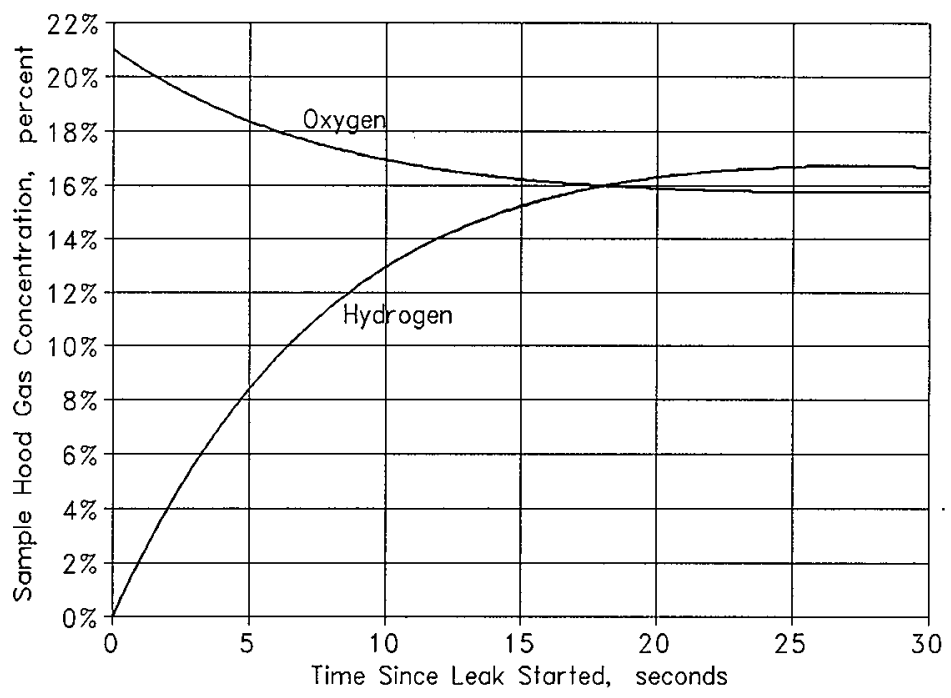




\section{SNE-3328 REV 0}

This page intentionally left blank. 


\subsection{CALCULATIONS FOR THERMAL RUNAWAY REACTIONS INSIDE THE MULTI-CANISTER OVERPACK}

\subsection{PURPOSE AND OBJECTIVES}

A thermal runaway reaction could occur in a multi-canister overpack (MCO) at the Canister Storage Building (CSB) if fuel temperatures are extremely high and if there is enough water or oxygen. Chemical reaction rates increase and produce more gases and heat as fuel temperatures increase. Pressure inside the $\mathrm{MCO}$ increases as a result. If pressure inside the MCO continues to increase to the point that the MCO pressure boundary is challenged, then the MCO could fail and release radioactive particulate and hydrogen gas into the surrounding environment.

The calculations summarized in this chapter demonstrate that a runaway fuel reaction accident is not credible at the CSB if the MCOs satisfy dryness tests at the Cold Vacuum Drying Facility (CVDF) and if the aluminum hydroxide thermal decomposition data remains valid and representative. No detailed accident scenarios were developed, but the bounding conditions used in this analysis are described. For these conditions, a thermal runaway event was determined to be credible at the CSB. It should be noted that with extreme temperatures (MCO wall temperatures greater than $115^{\circ} \mathrm{C}$ ) and a complete shear of an $\mathrm{MCO}$ that provides large quantities of air as an oxidant, a thermal fuel runaway could occur in the upper MCO scrap basket.

\subsection{SCENARIO DEVELOPMENT}

There are two primary chemical reactions that could lead to a thermal runaway event in an $\mathrm{MCO}$ at the CSB: (1) the reaction of water with uranium and uranium hydride $\left(\mathrm{UH}_{3}\right)$, and (2) the reaction of oxygen with uranium and uranium hydride.

There are two bounding scenarios for thermal runaway events involving the reaction of water with uranium and uranium hydride. The second scenario (Case 2) assumes water is thermally freed from the aluminum hydroxide and therefore bounds the first scenario (Case 1). The analyses of Cases 1 and 2 are described in Sections 6.4.1.4.1 and 6.4.1.4.2, respectively. No thermal runaways result in either case.

There are also two bounding scenarios for thermal runaway events involving the reaction of oxygen with uranium and uranium hydride: one scenario (Case 3) for an MCO being accidentally injected with oxygen and a second scenario (Case 4) for an MCO that sustains a complete shear while at a high temperature (MCO wall temperatures equal to $115^{\circ} \mathrm{C}$ ). The analyses of Cases 3 and 4 are described in Sections 6.2.2.1 and 6.2.2.2, respectively. All oxygen scenarios are bounded by Case 4 with one exception. The exception is the extreme case of a completely sheared MCO with wall temperatures greater than $115^{\circ} \mathrm{C}$ and the air temperature greater than $102{ }^{\circ} \mathrm{C}$, which is included as a design basis accident (Section 6.2.2.3). Case 3 describes an accident that is initiated when the MCO is accidentally filled with oxygen at the sampling/weld station. If the MCO were at a sufficiently high temperature, this condition could result in 
overpressurization of the MCO. (The MCO will not overpressurize at bounding MCO temperatures.) The unmitigated consequences of this event would not violate the safety limit on MCO pressure and would not violate criticality controls. No safety-class features are required to prevent or mitigate this event. Because no release would occur, offsite release limits and onsite evaluation guidelines are satisfied. The unmitigated scenario is brought to a stable state by ongoing MCO inerting and/or cooling at the sampling/weld station and the natural consumption of the oxygen. The off-normal MCO is handled within recovery operations under emergency response procedures, with the preferred approach being to move the off-normal MCO to the overpack storage tube for long-term observation and storage. Case 4 results in a violation of criticality geometry controls and a loss of the MCO confinement safety function (a complete shear), so it is prevented by safety-class equipment (analysis of violation of criticality geometry controls is discussed in Chapter 2.0). Case 4 does not result in a thermal runaway.

\subsubsection{Thermal Runaway Reaction from Water Reacting with Uranium and Hydride}

In the following subsections, the chemical reactions from water are briefly described, the amount of water required to breach the MCO (depending on gas temperature and gas reaction) is estimated, and the amount of water available in an MCO for chemical reactions is detailed. Values show that there would not be enough water to pressurize an MCO beyond its design limit.

6.2.1.1 Chemical Reactions with Water. Depending on temperature and steam pressure, water (liquid or vapor) will react with uranium and form uranium dioxide particulate and hydrogen gas, liberating heat during the reaction ( $\mathrm{RD} / \mathrm{B} / 6231 / \mathrm{R} 89)$ :

$$
\mathrm{U}+2 \cdot \mathrm{H}_{2} \mathrm{O}-\mathrm{UO}_{2}+2 \cdot \mathrm{H}_{2}+\text { heat . }
$$

Water will also react with uranium hydride $\left(\mathrm{UH}_{3}\right)$ to form uranium dioxide and hydrogen, liberating heat during the reaction (FAI/98-40):

$$
\mathrm{UH}_{3}+2 \mathrm{H}_{2} \mathrm{O}-\mathrm{UO}_{2}+3.5 \mathrm{H}_{2}+\text { heat } .
$$

\subsubsection{Water Mass Required to Reach the Multi-Canister Overpack Pressure Design}

Limit. The current design pressure of an $\mathrm{MCO}$ after the rupture disk port cover is fastened into place at the CVDF is $450 \mathrm{lb} / \mathrm{in}^{2}$ (31.6 atm absolute) (HNF-SD-SNF-DR-003). The hazard analysis assumed a $11.2 \mathrm{~atm}$ absolute (150 lb/in ${ }^{2}$ gauge) MCO mechanical seal design pressure, to provide a conservative assessment of the hazards to accommodate a lower MCO design pressure (HNF-SD-SNF-HIE-001). The mechanically sealed MCO design pressure after the cover cap is welded onto the MCO at the CSB sampling/weld station is also $450 \mathrm{lb} / \mathrm{in}^{2}$ (31.6 atm absolute). Most MCOs will have the cover caps welded on within days of arrival at the CSB; some MCOs caps will not be welded so the MCOs can be sampled and monitored (HNF-3312, HNF-3354). The MCOs reserved for sampling have significant time to pressurize before the MCO cover cap is welded in place, and all of the other MCOs have much less time to pressurize. 
Each MCO is pressurized to approximately $1.5 \mathrm{~atm}$ with helium before leaving the CVDF (SNF-2356). The average temperature of this helium is conservatively assumed to be $25^{\circ} \mathrm{C}$ because the $\mathrm{MCO}$ wall temperature is cooled to $25^{\circ} \mathrm{C}$ at the CVDF before the $\mathrm{MCO}$ is shipped to the CSB. Using the ideal gas law, the initial helium inventory in an MCO is estimated to be about 33 gmoles:

$$
\mathrm{N}_{\mathrm{He}}=(\mathrm{P})(\mathrm{V}) /(\mathrm{R}) /(\mathrm{T})
$$

where

$$
\begin{aligned}
& \mathrm{N}_{\mathrm{he}}=\text { number of gram-moles of helium in the MCO } \\
& \mathrm{P}=\text { helium pressure inside the MCO, } 1.5 \mathrm{~atm} \\
& \mathrm{~V}=\text { gas volume of the MCO, } 538 \mathrm{~L}(\mathrm{HNF}-\mathrm{SD}-\mathrm{SNF}-\mathrm{CN}-023) \\
& \mathrm{R}=\text { ideal gas law constant, } 0.082057 \mathrm{~L} \cdot \mathrm{atm} / \mathrm{mole} / \mathrm{K} \\
& \mathrm{T}=\text { temperature of the gas inside the } \mathrm{MCO}, 25^{\circ} \mathrm{C} .
\end{aligned}
$$

The number of moles of gas required to increase the $\mathrm{MCO}$ pressure (before the $\mathrm{MCO}$ and cover cap are welded together) to $11.2 \mathrm{~atm}$ and $31.6 \mathrm{~atm}$ can also be computed from the ideal gas law, if the gas temperature is known or assumed. If the $\mathrm{MCO}$ gas temperature is $150^{\circ} \mathrm{C}(423 \mathrm{~K})$, which is very conservative and beyond the bounding value of $125^{\circ} \mathrm{C}$ (HNF-SD-SNF-TI-015), about 173.5 moles of gas must be present in the MCO to achieve a pressure of $11.2 \mathrm{~atm}$. With about 33 moles of helium in an MCO at the time of arrival at the CSB, approximately 140.5 moles of other gases would need to be created at the CSB to reach 11.2 atm if the gas temperature was $150^{\circ} \mathrm{C}$.

If all of the newly created gases from the uranium-water reaction are hydrogen, then 140.5 moles $(2,530 \mathrm{~g})$ of water are needed to reach $11.2 \mathrm{~atm}$ at a $150^{\circ} \mathrm{C}$ gas temperature. If all of the created gas from the uranium hydride-water reaction is hydrogen, then only 80 moles $(1,440 \mathrm{~g})$ of water are needed to reach $11.2 \mathrm{~atm}$ at a $150^{\circ} \mathrm{C}$ gas temperature, because the hydride-water reaction produces 1.75 moles of hydrogen for every mole of water. Only $765 \mathrm{~g}$ of water are used to consume all of the hydride mass because there are only $5.13 \mathrm{~kg}$ of uranium hydride available (HNF-SD-SNF-TI-015). Hence, the hydride mass will take only $765 \mathrm{~g}$ of water before being depleted, producing about 74.5 moles of hydrogen. The remaining 66 moles ( 140.5 moles minus 74.5 moles) of gas required for $11.2 \mathrm{~atm}$ of pressure are supplied by 66 moles of water (uranium-water reaction), for a water mass of $1,190 \mathrm{~g}$. Adding the water consumed by the two reactions $(1,190 \mathrm{~g}$ plus $765 \mathrm{~g})$ yields about $1.96 \mathrm{~kg}$ of water, which is the amount of free water needed for gas-producing reactions to pressurize the $\mathrm{MCO}$ to $11.2 \mathrm{~atm}$ at a $150^{\circ} \mathrm{C}$ gas temperature. The same simple calculation is performed for the $31.6 \mathrm{~atm} \mathrm{MCO}$ pressure design limit and for lower gas temperatures. The results are shown in Table 6-1. After the water is consumed, hydrogen is expected to react with uranium to form uranium hydride (hydrogen gettering). For purposes of this analysis, no hydrogen gettering is assumed to conservatively bound the MCO pressure.

Table 6-1 lists the total free water required to reach gas pressures of $11.2 \mathrm{~atm}$ and $31.6 \mathrm{~atm}$ for water reactions and their combined weighted average (weighted towards the uranium-water 
reaction) at three different gas temperatures. The weighted average reaction is based on the fact that $0.765 \mathrm{~kg}$ of water is needed to consume the $5.13 \mathrm{~kg}$ of hydride, the bounding value for an $\mathrm{MCO}$ with two scrap baskets (HNF-SD-SNF-TI-015). The $125^{\circ} \mathrm{C}$ gas temperature is the maximum MCO gas temperature anticipated for CSB storage (HNF-SD-SNF-TI-015).

For comparative purposes, if the newly created gas is a stoichiometric mixture of hydrogen and oxygen due to radiolysis of water and the gas temperature is $150^{\circ} \mathrm{C}$, only about $1.37 \mathrm{~kg}$ of water needs to be available for a pressure of $11.2 \mathrm{~atm}$ to be attained. The radiolysis process is

Table 6-1. Water Mass Required to Pressurize Multi-Canister Overpack to 11.2 and 31.6 Atmospheres Versus Reaction and Gas Temperature.

\begin{tabular}{|c|c|c|c|}
\hline Chemical reaction & $\begin{array}{c}\text { Gas temperature } \\
100^{\circ} \mathrm{C}\end{array}$ & $\begin{array}{c}\text { Gas temperature } \\
125^{\circ} \mathrm{C}\end{array}$ & $\begin{array}{c}\text { Gas temperature } \\
150^{\circ} \mathrm{C}\end{array}$ \\
\hline \multicolumn{4}{|c|}{ Water mass required to reach $11.2 \mathrm{~atm}\left(150 \mathrm{lb} / \mathrm{in}^{2}\right.$ gauge $)$} \\
\hline Hydride-water & $1.69 \mathrm{~kg}$ & $1.56 \mathrm{~kg}$ & $1.45 \mathrm{~kg}$ \\
\hline Uranium-water & $2.95 \mathrm{~kg}$ & $2.73 \mathrm{~kg}$ & $2.53 \mathrm{~kg}$ \\
\hline Weighted average* & $2.38 \mathrm{~kg}$ & $2.15 \mathrm{~kg}$ & $1.96 \mathrm{~kg}$ \\
\hline \multicolumn{4}{|c|}{ Water mass required to reach $31.6 \mathrm{~atm}\left(450 \mathrm{lb} / \mathrm{in}^{2}\right.$ gauge $)$} \\
\hline Weighted average* & $8.83 \mathrm{~kg}$ & $8.20 \mathrm{~kg}$ & $7.65 \mathrm{~kg}$ \\
\hline Temperature value & High best estimate & Bounding & Beyond bounding \\
\hline
\end{tabular}

*Weighted average is based on a finite bounding uranium hydride mass (HNF-SD-SNF-TI-015, 1998, Spent Nuclear Fuel Project Technical Databook, Rev. 6, Fluor Daniel Hanford, Richland, Washington). The mass is completely consumed by hydride-water reaction.

very efficient in producing gas, because it generates 1.5 moles of hydrogen for every mole of water. This hydrogen production rate is not as efficient as the hydride-water reaction (1.75 moles of hydrogen per 1.0 mole of water), but is more efficient than the uranium-water reaction ( 1.0 mole hydrogen per 1.0 mole of water). However, the radiolysis process is very slow, even for a period of 40 years (HNF-SD-SNF-TI-040). For a period of one year or less, the amount of water radiolytically decomposed has been shown to be less than $0.5 \%$ of the water available in the free and hydroxide phases and less than $5 \%$ of the water in uranium hydrate $(1.19 \mathrm{~kg})$ (see Chapter 5.0). Because this analysis focuses on thermal behavior and resulting high pressures of the MCO at the CSB during the first year, the slowly occurring radiolysis process is not considered. Radiolysis is considered in Chapter 5.0 for flammability potential and high pressure concerns over the entire 40 -year projected storage period of an MCO at the CSB.

\subsubsection{Bounding Water Mass and its Availability for Reactions in Multi-Canister} Overpack. The projected bounding inventory of free water in an MCO received at the CSB is $200 \mathrm{~g}$. The bounding MCO is assumed to be dried at the CVDF, with less than $200 \mathrm{~g}$ of free 
water remaining in cracks after the dryness tests at the CVDF (HNF-1851, HNF-SD-SNF-TI-015).

In addition to the $200 \mathrm{~g}$ of free water, there is a bounding value of about $1.19 \mathrm{~kg}$ of water in the uranium hydrate that is part of the uranium oxide particulate matter (HNF-1523, HNF-SD-SNF-TI-015) for an MCO with two scrap baskets and three fuel baskets. However, this water would not be initially available for hydrogen-producing reactions, and some of the hydrate water is expected to be lost at the CVDF (HNF-SD-SNF-CN-023). Water molecules bound in the uranium hydrate $\left(\mathrm{UO}_{3} \cdot 2 \mathrm{H}_{2} \mathrm{O}\right)$ are freed at temperatures above about $60^{\circ} \mathrm{C}(\mathrm{FAI} / 98-40)$. Half the hydrate water (the first water molecule) liberates fairly easily, while the other half (the last water molecule) requires higher temperatures $\left(>100^{\circ} \mathrm{C}\right)$. Exact decomposition temperatures cannot be given because hydrate decomposition also depends on the relative humidity in the surrounding gas, with dry gases promoting faster decomposition and saturated gases stopping decomposition (FAI/98-40). The reaction for the two stages of hydrate decomposition is shown as:

$$
\begin{aligned}
& \mathrm{UO}_{3} \cdot 2 \mathrm{H}_{2} \mathrm{O} \rightarrow \mathrm{UO}_{3} \cdot \mathrm{H}_{2} \mathrm{O}+\mathrm{H}_{2} \mathrm{O} \rightarrow \mathrm{UO}_{3}+2 \mathrm{H}_{2} \mathrm{O} . \\
& \text { (if temperature }>60^{\circ} \mathrm{C} \text { ) (if temperature }>100^{\circ} \mathrm{C} \text { ) }
\end{aligned}
$$

The bounding water content $\mathrm{MCO}$ is one with two scrap baskets and three fuel baskets. For this $\mathrm{MCO}$, up to $3.32 \mathrm{~kg}$ of water is contributed by both the bounding quantity of aluminum hydroxide on the fuel cladding and by an additional $0.13 \mathrm{~kg}$ of water in aluminum and iron hydrates in the canister sludge (HNF-1523, HNF-SD-SNF-TI-015). This bound water, like the uranium hydrate water, would not initially be available for reactions. Very little of the hydroxide water is expected to be freed from the thermal decomposition of the hydroxide based on current data that suggests about $5 \%$ of the water decomposes for fuel temperatures less than $200{ }^{\circ} \mathrm{C}$ (HNF-1523). Less than 15\% of the water decomposes for fuel temperatures less than $300^{\circ} \mathrm{C}$. For normal operations at the sampling/weld station, the $\mathrm{MCO}$ gas temperatures will be less than $100^{\circ} \mathrm{C}$ (HNF-2256). However, for certain severe off-normal conditions at the station MCO gas temperatures could rise above $100^{\circ} \mathrm{C}$; hence, partial thermal decomposition of aluminum hydroxide is considered in the off-normal event calculations. The reaction is shown as:

$$
\begin{gathered}
2 \cdot \mathrm{Al}(\mathrm{OH})_{3} \rightarrow \mathrm{Al}_{2} \mathrm{O}_{3}+3 \cdot \mathrm{H}_{2} \mathrm{O} . \\
\quad \text { (if temperature }>100^{\circ} \mathrm{C} \text { ) }
\end{gathered}
$$

The expected bounding amounts of water in an MCO from all sources on arrival at the CSB and the availability of the water for reactions are shown in Table 6-2 as a function of fuel temperature. If the $\mathrm{MCO}$ fuel temperatures reach values greater than $200^{\circ} \mathrm{C}$, then the thermal decomposition of aluminum hydroxide, along with hydrate decomposition and initial free water, could supply about $1.91 \mathrm{~kg}$ of water. This total is based on $15 \%$ thermal decomposition of the aluminum and iron hydroxide and hydrate (HNF-1523), 100\% thermal decomposition of the uranium hydrate, and $0.2 \mathrm{~kg}$ of free water.

The bounding water mass numbers in Table 6-3 are derived from the required water amounts identified in Table 6-1 and the available water amounts identified in Table 6-2. Table 6-3 
Table 6-2. Bounding Water Mass and Availability for Reactions in Multi-Canister Overpack.

\begin{tabular}{|l|c|c|c|c|}
\hline \multirow{2}{*}{ Source of water } & \multirow{2}{*}{$\begin{array}{c}\text { Total possible } \\
\text { water mass }\end{array}$} & \multicolumn{3}{|c|}{$\begin{array}{c}\text { Availability of water for reactions } \\
\text { (Thermal decomposition, percent of total mass) }\end{array}$} \\
\cline { 3 - 5 } & & Fuel T $\leq 100^{\circ} \mathrm{C}$ & Fuel T=200 ${ }^{\circ} \mathrm{C}$ & Fuel T=300 ${ }^{\circ} \mathrm{C}$ \\
\hline Free water in cracks & $0.20 \mathrm{~kg}$ & $0.20 \mathrm{~kg}$ & $0.20 \mathrm{~kg}$ & $0.20 \mathrm{~kg}$ \\
\hline $\begin{array}{l}\text { Water in uranium } \\
\text { hydrate }\end{array}$ & $1.19 \mathrm{~kg}$ & $\begin{array}{c}0.60 \mathrm{~kg} \\
(50 \%)\end{array}$ & $\begin{array}{c}1.19 \mathrm{~kg} \\
(100 \%)\end{array}$ & $\begin{array}{c}1.19 \mathrm{~kg} \\
(100 \%)\end{array}$ \\
\hline $\begin{array}{l}\text { Water in aluminum } \\
\text { hydroxide }\end{array}$ & $3.32 \mathrm{~kg}$ & $0.0 \mathrm{~kg}$ & $\begin{array}{c}0.166 \mathrm{~kg} \\
(5 \%)\end{array}$ & $\begin{array}{c}0.50 \mathrm{~kg} \\
(15 \%)\end{array}$ \\
\hline $\begin{array}{l}\text { Water in Al+Fe } \\
\text { hydrates }\end{array}$ & $0.13 \mathrm{~kg}$ & $0.0 \mathrm{~kg}$ & $0.007 \mathrm{~kg}$ & $0.02 \mathrm{~kg}$ \\
$(5 \%)$ & $(15 \%)$ \\
\hline TOTAL & $4.84 \mathrm{~kg}$ & $0.80 \mathrm{~kg}$ & $1.56 \mathrm{~kg}$ & $1.91 \mathrm{~kg}$ \\
\hline
\end{tabular}

Table 6-3. Additional Water Mass Needed to Pressurize Multi-Canister Overpack to 11.2 and 31.6 Atmospheres for Different Gas Temperatures.

\begin{tabular}{|c|c|c|c|}
\hline Water balance description & $\begin{array}{c}\text { Gas temperature } \\
100^{\circ} \mathrm{C}\end{array}$ & $\begin{array}{c}\text { Gas temperature } \\
125^{\circ} \mathrm{C}\end{array}$ & $\begin{array}{c}\text { Gas temperature } \\
150^{\circ} \mathrm{C}\end{array}$ \\
\hline \multicolumn{4}{|c|}{$11.2 \mathrm{~atm}\left(150 \mathrm{lb} / \mathrm{in}^{2}\right.$ gauge $)$} \\
\hline $\begin{array}{l}\text { Total water required to reach } \\
150 \mathrm{lb} / \mathrm{in}^{2} \text { gauge (Table } 6-1 \text { ) }\end{array}$ & $2.38 \mathrm{~kg}$ & $2.15 \mathrm{~kg}$ & $1.96 \mathrm{~kg}$ \\
\hline $\begin{array}{l}\text { Total free water available } \\
\text { (Table 6-2) }\end{array}$ & $0.80 \mathrm{~kg}$ & $1.56 \mathrm{~kg}$ & $1.56 \mathrm{~kg}^{*}$ \\
\hline $\begin{array}{l}\text { Additional water needed to } \\
\text { reach } 150 \mathrm{lb} / \mathrm{in}^{2} \text { gauge (water } \\
\text { shortage at the CSB) }\end{array}$ & $1.58 \mathrm{~kg}$ & $0.59 \mathrm{~kg}$ & $0.40 \mathrm{~kg}$ \\
\hline \multicolumn{4}{|c|}{$31.6 \mathrm{~atm}\left(450 \mathrm{lb} / \mathrm{in}^{2}\right.$ gauge $)$} \\
\hline $\begin{array}{l}\text { Total water required to reach } \\
\left.450 \mathrm{lb} / \text { in }^{2} \text { gauge (Table } 6-1\right)\end{array}$ & $8.83 \mathrm{~kg}$ & $8.20 \mathrm{~kg}$ & $7.65 \mathrm{~kg}$ \\
\hline $\begin{array}{l}\text { Free water available } \\
\text { (Table 6-2) }\end{array}$ & $0.80 \mathrm{~kg}$ & $1.56 \mathrm{~kg}$ & $1.56 \mathrm{~kg}^{*}$ \\
\hline $\begin{array}{l}\text { Additional water needed to } \\
\text { reach } 450 \mathrm{lb} / \mathrm{in}^{2} \text { gauge } \\
\text { (water shortage at the CSB) }\end{array}$ & $8.03 \mathrm{~kg}$ & $6.64 \mathrm{~kg}$ & $6.09 \mathrm{~kg}$ \\
\hline Gas temperature value & High best estimate & Bounding & Beyond bounding \\
\hline
\end{tabular}

*Fuel $\mathrm{T} \leq 200^{\circ} \mathrm{C}$.

$\mathrm{CSB}=$ Canister Storage Building. 
shows the additional free water that would be needed at different gas temperatures for MCO pressures to increase to 11.2 and $31.6 \mathrm{~atm}$ (150 and $450 \mathrm{lb} / \mathrm{in}^{2}$ gauge). It is assumed in Table 6-3 that the peak fuel temperatures will not be more than $50^{\circ} \mathrm{C}$ higher than the gas temperatures, which has been shown to be true for most conditions (HNF-SD-SNF-CN-023). The peak fuel temperatures occur on the innermost fuel assemblies or scrap and are no more than $50{ }^{\circ} \mathrm{C}$ higher than the average gas temperature whereas the peripheral fuel elements or scrap are cooler than the average gas temperature.

Table 6-3 shows that, under normal conditions, at least $8.03 \mathrm{~kg}$ of additional free water would need to be available in an MCO at the CSB for the MCO pressure to reach the $31.6 \mathrm{~atm}\left(450 \mathrm{lb} / \mathrm{in}^{2}\right.$ gauge $)$ design pressure. Even under conditions that are beyond the bounding temperature causing more bound water to be liberated, at least $6.09 \mathrm{~kg}$ of additional free water would need to be available. The amount of water required to pressurize the MCO to its $31.6 \mathrm{~atm}$ (450 lb/in ${ }^{2}$ gauge) design pressure was shown to be at least $7.65 \mathrm{~kg}$ (see Tables $6-1$ and 6-2), which is more than the $4.84 \mathrm{~kg}$ total water that could be available in an MCO (HNF-SD-SNF-TI-015). Hence, if all the water (4.84 kg, Table 6-2) in the free, hydrate, and hydroxide phases were available for chemical reactions, the $\mathrm{MCO}$ pressure would still stay below the $450 \mathrm{lb} / \mathrm{in}^{2}$ gauge design pressure. Hence, the $\mathrm{MCO}$ design pressure is high enough to provide a large margin of safety with regard to gas production from uranium-water and hydride-water chemical reactions.

However, if the design pressure of interest were $11.2 \mathrm{~atm}\left(150 \mathrm{lb} / \mathrm{in}^{2}\right.$ gauge) instead of $31.6 \mathrm{~atm}\left(450 \mathrm{lb} / \mathrm{in}^{2}\right.$ gauge), the additional water margin would be much smaller (see Table 6-3). In fact, only $0.4 \mathrm{~kg}$ of additional water is needed to pressurize the MCO to $11.2 \mathrm{~atm}$ at the CSB under beyond bounding conditions. Because this margin is small and the calculations are only approximate, the HANSF code (FAI/98-40) was used to simulate a very hot MCO in the sampling/weld station under severe off-normal conditions.

6.2.1.4 Computer Simulations of High-Temperature Scenarios. The HANSF code, Version 1.2 (FAI/98-40; HNF-SD-SNF-CN-023) was used to simulate bounding events with high temperature boundary conditions. The HANSF code has been used extensively for analyses of CVDF processes and its quality assurance has been documented (HNF-SD-SNF-CN-023). The models developed for the code include the inner and outer fuel elements in each fuel assembly and 54 fuel assemblies per fuel basket. The models also include the scrap basket, which is physically modeled like a porous bed of gravel.

The high-temperature scenario analysis was motivated by the high-temperature calculations documented in CSB-HV-0014; Long Term MCO Temperature Without Cooling in the Sampling Station. Those calculations analyzed an MCO in the sampling/weld station without active cooling for about two months. The MCO handling machine (MHM) was also assumed to be unable to remove the MCO from the sampling/weld station. For this unmitigated scenario, a $132{ }^{\circ} \mathrm{C} \mathrm{MCO}$ wall temperature was calculated to occur in about 50 days (CSB-HV-0014). The calculation showed that the wall temperature would still be slowly increasing at 50 days, so the steady-state temperature would be greater than $132{ }^{\circ} \mathrm{C}$, but less than $138^{\circ} \mathrm{C}$ (CSB-HV-0014). These temperature comments are based on the small increase at 68 days shown in CSB-HV-0014; 
however, the steady-state temperature was not actually calculated and the fuel temperatures were not part of that calculation. Therefore, the current analysis focuses on fuel temperatures and MCO pressure rather than the concrete temperature.

There were two high-temperature cases with water-based reactions analyzed with Version 1.2 of the HANSF code (FAI/98-40). The key input parameters are given in Appendix $\mathrm{C}$. The simulations utilized a bounding MCO with one scrap basket and four fuel baskets. However, the simulated water content of this $\mathrm{MCO}$ was equivalent to that of an $\mathrm{MCO}$ with two scrap baskets and three fuel baskets. An MCO with two scrap baskets has the maximum hydrate water $(1.19 \mathrm{~kg})$ and total water $(4.84 \mathrm{~kg})$ in the free, hydrate, and hydroxide phases. The MCO with one scrap basket has more decay heat than the MCO with two scrap baskets, because a fuel basket has more heat (or mass) than a scrap basket. To maximize the results and minimize the number of simulations, a hypothetical MCO that had the decay heat of an MCO with one scrap basket and the water content of an MCO with two scrap baskets was simulated. The temperature results of the single scrap basket would represent any behavior of a second scrap basket.

The total reaction surface area is not maximized for the entire $\mathrm{MCO}$. The total reaction surface area is not important at the CSB because the oxidants (water or oxygen) are the most limiting reactants. After the CVDF, water is very limited and air is not present in an MCO. For air ingress scenarios, a single scrap basket with a $4.5 \mathrm{~m}^{2}$ bounding surface area will determine the bounding temperature results for a second scrap basket, if present. The second scrap basket would compete with the first basket for oxidants such that the first basket would not heat as much. All of the following results are obtained with this bounding, hypothetical MCO.

6.2.1.4.1 Case 1 (CHOT2SCE). A bounding MCO is in the sampling/weld station for at least 50 days without active cooling. The calculated fuel temperatures are consistent with the 132 ${ }^{\circ} \mathrm{C}$ MCO wall temperature. Simulations for this case assumed initial fuel temperatures of $125^{\circ} \mathrm{C}$ and calculated the temperatures for two days. It was assumed that the $1.5 \mathrm{~atm}$ of helium injected at the CVDF included water. The water was assumed to be $2 \%$ (saturated steam at $25{ }^{\circ} \mathrm{C}$ ) of the injected helium, which amounts to about $9 \mathrm{~g}$ of water mass. Steady-state temperatures for this case were attained in less than a day of simulated time.

The fuel temperatures for Case 1 are shown in Figures 6-1 and 6-2 as a function of time. The hottest fuel temperature for Case 1 occurs on the inner fuel element nearest the center post of the MCO. This temperature is about $152^{\circ} \mathrm{C}$ for the middle fuel baskets and about $151{ }^{\circ} \mathrm{C}$ for the bottom fuel baskets. The hottest temperature for the scrap fuel is about $140^{\circ} \mathrm{C}$. The scrap fuel is cooler than the fuel elements because the scrap basket copper fins effectively conduct heat toward the $\mathrm{MCO}$ wall and because some heat escapes from the scrap to the shield plug.

The MCO gas temperature reaches about $148^{\circ} \mathrm{C}$ in the fuel baskets and about $136^{\circ} \mathrm{C}$ in the scrap basket. The time in Figures 6-1 and 6-2 starts after the MCO wall temperature reaches $132{ }^{\circ} \mathrm{C}$, which would be at least 50 days after the passively cooled $\mathrm{MCO}$ is placed in the sampling/weld station (CSB-HV-0014). The initial helium temperature is $25^{\circ} \mathrm{C}$ when it is injected into the $\mathrm{MCO}$ at a pressure of about $1.5 \mathrm{~atm}$ at the CVDF. In the simulation the gas 
heats up in about two or three minutes, due to the low heat capacity of the gas, and causes a rapid pressure increase. Such a rapid increase will not happen in reality because the MCO is cooled at the CVDF before the helium is injected and cannot heat up to the initial temperatures assumed in this scenario fast enough. The MCO gas pressure reaches $7.0 \mathrm{~atm}$ in two days, but the pressure does not increase at a significant rate after those two days.

6.2.1.4.2 Case 2 (CHOT2SCR). Case 2 uses the final results of Case 1 for all initial conditions (e.g., the hottest fuel element is about $152^{\circ} \mathrm{C}$ initially, the time starts at two days). Case 2 investigates the effects of hydrated water on $\mathrm{MCO}$ reaction as a continuation of Case 1. This simulation adds $0.52 \mathrm{~kg}$ of water, which is about $15 \%$ of the water contained in aluminum hydroxide and the aluminum and iron hydrates in the canister sludge (HNF-SD-SNF-TI-015). Data indicates that as much as $5 \%$ of the hydroxide water can be freed by thermal decomposition for temperatures up to $200{ }^{\circ} \mathrm{C}$, and about $15 \%$ can be freed for temperatures up to $300^{\circ} \mathrm{C}$ (HNF-1523). In Case 1, the maximum fuel temperature was $152^{\circ} \mathrm{C}$, at which temperature less than $5 \%$ of the water in aluminum hydroxide is expected to be freed. Because thermal decomposition of aluminum hydroxide is not part of the models for the HANSF code, additional water vapor (steam) was added as a source to simulate the aluminum hydroxide's effect on temperatures and pressure. To be conservative, $15 \%$ or $0.52 \mathrm{~kg}$ of hydroxide water was added to Case 2 over a 10,000 second interval, which is a faster rate than the expected real thermal decomposition rate (HNF-1523).

In the simulation, the freed hydroxide water was added only to the middle fuel baskets, which is more conservative than evenly distributing the water to all the baskets. The added hydroxide water causes the maximum fuel temperature to increase from $152{ }^{\circ} \mathrm{C}$ to about $170^{\circ} \mathrm{C}$ in less than three hours (shown in Figure 6-3). All of the temperature and pressure results for this case are shown in Figures 6-3 and 6-4. The fuel and gas temperatures decrease after three hours because no more water is available to continue the chemical reactions. In less than two days, the maximum fuel temperature reaches a lower steady-state value of $150^{\circ} \mathrm{C}$. The additional water creates hydrogen gas, which has a very high thermal conductivity and heat is removed from the MCO faster. The scrap fuel does not heat up, indicating that no steam enters the scrap basket from the middle fuel baskets. The fuel temperatures in the bottom fuel basket also do not increase, which indicates that no steam flows downward into the bottom fuel baskets. The MCO pressure rises to just above 10.0 atm (shown in Figure 6-4), which is well below the MCO design pressure of $31.6 \mathrm{~atm}$ ( $450 \mathrm{lb} / \mathrm{in}^{2}$ gauge). The maximum fuel temperature does not rise above $170^{\circ} \mathrm{C}$ and the gas temperature does not rise much above $150^{\circ} \mathrm{C}$, indicating that the helium provides good thermal conductivity, thereby keeping the temperatures stable in the $\mathrm{MCO}$ at the CSB.

6.2.1.5 Conclusions and Conservatisms. The simulations show that MCO temperatures will remain stable even under very severe external thermal conditions, and the maximum gas pressure will stay below $11.2 \mathrm{~atm}$, which is far below the $31.6 \mathrm{~atm}$ ( $450 \mathrm{lb} / \mathrm{in}^{2}$ gauge) MCO design pressure. This controlled behavior was shown even with many conservatisms included in the evaluation. The main conservatisms and/or margins over bounding parameter values used in the computer simulations are itemized in the following list. 
- No hydrate water is removed at the CVDF, leaving all hydrate water available for thermal decomposition at the CSB

- No hydride mass is depleted at the CVDF and none is consumed at the CSB, as the hydride reaction rate multiplier was kept at 12 (HNF-SD-SNF-TI-015) for all simulations at all times

- An MCO with the bounding quantity of aluminum hydroxide is not expected to have a decay power greater than $528 \mathrm{~W}$ (HNF-3035)

- $\mathrm{MCO}$ wall temperature is $138^{\circ} \mathrm{C}$ as the result of being in the sampling/weld station pit without active cooling for more than 50 days (CSB-HV-0014)

- Steam mass of $9 \mathrm{~g}$ is added to the MCO to account for the CVDF helium supply possibly being contaminated with $2 \%$ steam

- Fifteen percent of aluminum hydroxide water is released at $<200{ }^{\circ} \mathrm{C}$ instead of $300^{\circ} \mathrm{C}$ (HNF-1523) for Case 2, and this water is added only to middle fuel baskets instead of evenly distributing the water source

- No hydrogen gettering takes place, which maximizes the gas pressure; if hydrogen gettering was allowed to take place, the hydrogen gas fraction in the MCO would be significantly reduced, thereby lowering the MCO pressure. Hydrogen gettering is expected to occur after all of the free water has been depleted and this process could lower the MCO pressure by as much as $80 \%$.

\subsubsection{Thermal Runaway Reaction from Oxygen Reacting with Uranium Hydride and Uranium}

Heat can also be generated in an MCO when oxygen (or air) enters as the result of an off-normal event or as the result of radiolysis. This section examines the entrance of oxygen or air as the result of an off-normal event. Chapter 5.0 examines the long-term effects of radiolysis and flammability issues. Any oxygen that enters the $\mathrm{MCO}$ will react with uranium hydride and uranium to liberate heat, depending on the temperature (HNF-SD-SNF-TI-015). These reactions are as follows:

$$
\begin{gathered}
\mathrm{UH}_{3}+1.75 \mathrm{O}_{2} \rightarrow \mathrm{UO}_{2}+1.5 \mathrm{H}_{2} \mathrm{O}+\text { heat } \\
\mathrm{U}+\mathrm{O}_{2}-\mathrm{UO}_{2}+\text { heat } .
\end{gathered}
$$

A high-pressure condition in an MCO is impossible with an air ingress event because pressure decreases when oxygen is consumed. However, with the heat liberated in these reactions, a thermal runaway or excursion without the high pressure is still possible. Furthermore, because these reactions with oxygen liberate heat and increase the fuel and gas temperatures, 
additional water could decompose from the uranium hydrate and aluminum hydroxide, which would increase the pressure and temperature in the $\mathrm{MCO}$. The reactions with oxygen will be followed by the reactions with water after the oxygen is consumed. Because all of these reactions are coupled and inter-related, the HANSF code (FAI/98-40) was used to simulate the air ingress case.

The HANSF code (FAI/98-40), was used to evaluate the competing reactions and to demonstrate that a thermal runaway does not occur for two different bounding air entry cases. Full realistic scenarios were not developed because no thermal runaways are expected even for very conservative or extremely off-normal conditions.

6.2.2.1 Case 3 (COXY2SC2). An MCO is charged with pure oxygen instead of helium at the CSB sampling/weld station during gas sampling (i.e., helium cylinders accidentally filled with oxygen or oxygen cylinders accidentally used in place of helium). In obtaining a gas sample from one of the monitored MCOs, the helium pressure in the $\mathrm{MCO}$ is accidentally reduced to $1.0 \mathrm{~atm}$. Hence, when oxygen, instead of helium, is accidentally injected into the MCO to get the pressure back up to $1.5 \mathrm{~atm}, 0.5 \mathrm{~atm}$ (about $33 \%$ ) of the total pressure is due to oxygen. It is also assumed that only passive cooling is available in the sampling/weld station such that the air temperature and MCO wall temperature are both $138^{\circ} \mathrm{C}$. This maximum steady-state temperature is only reached after at least 50 days in the sampling/weld station with no active cooling (CSB-HV-0014). All fuel temperatures are conservatively assumed to be $163^{\circ} \mathrm{C}$ in the HANSF simulation.

A thermal excursion occurs when there are sufficient uranium reactions to lead to an internal MCO pressure that exceeds the design pressure. If oxygen reactions starting at high temperatures do not cause thermal excursion, then no thermal excursion would result for oxygen reactions starting at lower temperatures. This scenario is very conservative and may not be credible, but it is expected to bound all air entry cases (except the complete shear of an $\mathrm{MCO}$ at elevated temperature $\mathrm{MCO}$ ) and cases with helium cylinders contaminated with air or oxygen. This case bounds all air ingress events, without complete shear, at the sampling/weld station because $100 \%$ oxygen is postulated to be injected and air has an oxygen content of only $21 \%$. Air ingress through a single orifice (around $1 \mathrm{in}$. in diameter) cases are bounded by this scenario because very little air can flow into the $\mathrm{MCO}$ against the gas being generated within and flowing out of the MCO. Also, no natural circulation with air ingress is expected at the CSB because natural circulation requires two openings, one for air entry and one for gas exit, and two openings are not available in the MCO at the CSB. However, the effects of one very large opening, such as in a complete shear is different. Results indicate that the shearing case temperatures are bounded by the oxygen injection case temperatures evaluated here. However, to prevent a thermal excursion the initial fuel temperatures during a shear accident must be cooler $\left(125^{\circ} \mathrm{C}\right)$ than fuel temperatures in the oxygen injection case $\left(163^{\circ} \mathrm{C}\right)$. If the $\mathrm{MCO}$ wall temperature was greater than $115^{\circ} \mathrm{C}$ and if there were a complete shear of the $\mathrm{MCO}$ top, the fuel could experience run away reactions. However, with an $\mathrm{MCO}$ wall temperature of $115^{\circ} \mathrm{C}$ or less, the fuel does not reach the $725{ }^{\circ} \mathrm{C}$ temperature guidelines (HNF-SD-SNF-SARR-005) if a complete shear of the MCO top occurs. The complete shear scenario was simulated in Case 4 because it represents a physical situation with an unlimited amount of oxidant reaching the fuel. 
The temperature and pressure results for Case 3 are shown in Figures 6-5 and 6-6. The design basis accident for air ingress was chosen to be Case 3 , with oxygen instead of helium injected at the gas sampling station. For Case 3, the innermost fine scrap fuel has a thermal increase up to almost $420^{\circ} \mathrm{C}$ before the oxygen is depleted in the scrap basket and cools off rapidly (see Figure 6-5). This temperature increase occurs because the fine scrap fuel has a high surface-area-to-volume ratio and is initially $163^{\circ} \mathrm{C}$, which is hot enough to rapidly oxidize the uranium hydride in the scrap fuel and dramatically increase the fine scrap temperature. The oxygen-hydride reaction at this high temperature rapidly consumes the oxygen, depleting it within an hour. There is not enough water available to continue the chemical reactions, because the dehydration process is too slow to keep the temperatures high. If aluminum hydroxide is included, only a small amount of water is expected to be freed by thermal decomposition because elevated temperatures exist for less than an hour and are restricted to only the innermost fine scrap.

The maximum MCO pressure of about $6.2 \mathrm{~atm}$ is far below the $31.6 \mathrm{~atm} \mathrm{MCO}$ design pressure. This maximum pressure is lower than that found in Cases 1 and 2 , as expected, because the oxygen reactions do no produce as much gas as the water reactions. The pressure is also lower because the temperatures are generally not as high and the hydrates do not completely decompose, which means less water reacts.

6.2.2.2 Case 4 (CAIR2SC). In Case 4, the MCO is in the MHM without the MHM extract system cooling fan turned on. An analysis by the MHM manufacturer showed that the MCO wall temperature can reach a steady-state temperature of $115^{\circ} \mathrm{C}$ and an MHM air temperature of $102^{\circ} \mathrm{C}$. Case 4 uses these temperatures and assumes that the MHM completely shears off the top, providing a large opening for air to enter the MCO. The scrap fuel and in-tact fuel assembly temperatures are assumed to be $125^{\circ} \mathrm{C}$. Under these hot conditions, the oxygen in the air reacts with both the uranium fuel and uranium hydride at a high enough rate to slowly increase the fuel temperatures. The scrap basket has better heat rejection than the fuel basket, especially because it is exposed to $102^{\circ} \mathrm{C}$ air above it. Hence, the scrap fuel does not heat up as fast as the inner fuel elements, which reach high temperatures very rapidly after 18 hours (shown in Figure 6-7). The maximum temperature reached by the innermost fuel assemblies is about $540^{\circ} \mathrm{C}$, which is still below the uranium-iron eutectic temperature of $725^{\circ} \mathrm{C}$ (HNF-SD-SNF-SARR-005).

6.2.2.3 Beyond Design Basis Accident. In Case 4 at the MHM without its fan on, the air temperature is $102{ }^{\circ} \mathrm{C}$, based on the previous analysis. Calculations have shown that if the air temperature in the MHM was higher than $102{ }^{\circ} \mathrm{C}\left(\right.$ e.g., $\left.115^{\circ} \mathrm{C}\right)$, then the scrap fuel would start burning rapidly within 8 hours of a complete shear and be completely oxidized in about 10 additional hours. This $100 \%$ scrap fuel burn (oxidation) generates about $1,000 \mathrm{~kg}$ of $\mathrm{UO}_{2}$, which is the approximate material at risk in the scrap basket. This material at risk can produce an airborne source term of about $1 \mathrm{~kg}$ of $\mathrm{UO}_{2}$, given a respirable airborne release fraction of $1 \times 10^{-3}$ for oxidizing uranium (DOE-HDBK-3010-94). This source term results in an offsite dose of about 1 rem over a 12-hour period. The fuel in the MCO and the air in the MHM should never be hot enough $\left(\leq 102^{\circ} \mathrm{C}\right)$ to cause a large fuel burn, as is demonstrated in Case 4. Hence, the conditions required for a large fuel burn are beyond the design basis accident for a complete shear providing unlimited oxidant for fuel reactions. 
6.2.2.4 Conclusions and Conservatisms. Temperatures remain stable even under very severe external thermal conditions. However, the MCO pressure could get very close to the MCO pressure design limit. This could be a problem, but there are many conservatisms in the evaluation. The main conservatisms and/or margins over bounding parameter values assumed in the computer simulations are itemized as follows:

- No hydrate water is removed at the CVDF, leaving all hydrate water is available for thermal decomposition at the CSB.

- No hydride mass is depleted at the CVDF and it is not depleted at the CSB, as the hydride reaction rate multiplier was kept at 12 (HNF-SD-SNF-TI-015) for all times, which kept the hydride-oxygen reaction going. In reality, much of the hydride would be consumed at the CVDF and not be available at the CSB.

- An MCO with the bounding quantity of aluminum hydroxide is not expected to have a decay power greater than $528 \mathrm{~W}(\mathrm{HNF}-3035)$

- $\mathrm{MCO}$ wall temperature is $138^{\circ} \mathrm{C}$ because the $\mathrm{MCO}$ is placed in the sampling/weld station for several weeks without active cooling.

Even with all of the above margins in the simulations, the calculated MCO gas pressure stays far below the MCO design pressure of $31.6 \mathrm{~atm}$ ( $450 \mathrm{lb} / \mathrm{in}^{2}$ gauge). The fuel temperatures also are stable after an increase in the innermost fine scrap fuel due to oxidization of the uranium hydride and the large area-to-volume ratio of the fine scrap. Even for a complete shear of a

high-temperature MCO, the fuel temperatures stay below guidelines (HNF-SD-SNF-SARR-005).

\subsection{SOURCE TERM ANALYSIS}

Because there is no release expected even under severe off-normal conditions, no source term was estimated.

\subsection{CONSEQUENCE ANALYSIS}

Because there is no release expected, even under severe off-normal conditions, the inhalation dose consequences are zero.

\subsection{COMPARISON TO GUIDELINES}

Because the dose consequences are zero for thermal runaway reaction events at the CSB, all dose guidelines are met. These results are predicated on the condition that the MCOs passed the dryness tests at the CVDF that ensure that less than $200 \mathrm{~g}$ of free water can be present in the MCO after leaving the CVDF. The results depend on the amount of hydrides in the MCO and the 
amount of aluminum hydroxide, as well as their thermal decomposition rates as a function of temperature. If the MCO design pressure were lowered to $150 \mathrm{lb} / \mathrm{in}^{2}$ gauge, then there would still be no dose consequences or safety limit violation, but the margin of safety would be significantly reduced.

The equivalent cases involving MCOs with two scrap baskets, analyzed and presented here, maximize the amount of water and hydrides in the MCO. These cases are expected to bound the thermal and high-pressure estimates and associated consequences when compared with events involving an $\mathrm{MCO}$ with one scrap basket or an $\mathrm{MCO}$ with no scrap baskets.

\subsection{SUMMARY OF SAFETY-CLASS STRUCTURES, SYSTEMS, AND COMPONENTS AND TECHNICAL SAFETY REQUIREMENT CONTROLS}

No safety-class or safety-significant structures, systems, and components (SSCs) are required to prevent the consequences of this accident. The technical safety requirement (TSR) controls designated to mitigate or prevent the bounding $\mathrm{MCO}$ thermal runaway accident are as follows:

- MHM interlocks, switches, and sensors that prevent the translational or rotational shears of the MCO that allow direct air-fuel interactions; calculations indicate that a complete shear of an MCO with outer wall temperatures greater than or equal to $115^{\circ} \mathrm{C}$ (where the maximum design temperature of the $\mathrm{MCO}$ is $132^{\circ} \mathrm{C}$ ), may lead to fuel thermal runaway situations.

All of the hazards related to fuel reactions that could cause a release are shown in Table 6-4. The fuel reactions with water hazards were identified with zero-release consequences in the CSB hazard analysis because of insufficient free water (HNF-SD-SNF-HIE-001). The performance assumption that is key to preventing fuel reactions with water is as follows:

- Assumption

- The $\mathrm{K}$ Basins washing process and the drying process at the CVDF will ensure the key performance assumptions defined in Chapter 1.0, Table 1-6, are met.

The SSCs and TSR controls designated to prevent the MCO thermal runaway accident are summarized in Table 6-4. U.S. Nuclear Regulatory Commission important-to-safety categories and defense-in-depth features also are included for each specific accident in Table 6-4.

The suite of safety SSCs and TSR controls necessary and sufficient to prevent the MCO thermal runaway accident do not address some of the other accidents in the same accident category. Table 6-4 lists the safety SSCs and TSR controls needed to prevent of control these accidents. Because these accidents are substantially different in development and progression 
Table 6-4. Summary of Safety Features Required to Prevent a Multi-Canister Overpack Thermal Runaway. (3 sheets)

\begin{tabular}{|c|c|c|c|c|}
\hline Accident & $\begin{array}{l}\text { Checklist } \\
\text { designator }\end{array}$ & $\begin{array}{l}\text { General } \\
\text { function }\end{array}$ & Safety features and safety classification ${ }^{b}$ & $\begin{array}{l}\text { NRC ITS } \\
\text { category }^{b}\end{array}$ \\
\hline \multicolumn{5}{|c|}{ Runaway reaction } \\
\hline $\begin{array}{l}\text { Use of } \\
\text { contaminated } \\
\text { (with oil) or } \\
\text { wrong gas } \\
\text { for inerting } \\
\text { (oxygen) } \\
\text { leads to a } \\
\text { hydrogen } \\
\text { explosion in } \\
\text { the MCO }\end{array}$ & WS-H-06b & $\begin{array}{l}\text { None at the } \\
\text { CSB } \\
\text { required for } \\
\text { safety }\end{array}$ & $\begin{array}{l}\text { Defense in depth: } \\
\text { Personnel are trained to facility-specific procedures } \\
\text { regarding maintenance, handling and receipt inspection } \\
\text { of gas cylinders. }\end{array}$ & \\
\hline \multicolumn{5}{|c|}{ Fuel reaction with air } \\
\hline $\begin{array}{l}\text { Fuel reaction } \\
\text { with air, } \\
\text { consequence } \\
\text { s of this } \\
\text { event are } \\
\text { bounded by } \\
\text { WS-H-06b }\end{array}$ & $\begin{array}{l}\text { SA-J-10a } \\
\text { OA-J-10a } \\
\text { WS-J-10a }\end{array}$ & $\begin{array}{l}\text { None at the } \\
\text { CSB } \\
\text { required for } \\
\text { safety }\end{array}$ & $\begin{array}{l}\text { Defense in depth: } \\
\text { - Prevent oxygen from entering the MCO } \\
\text { - Prevent high fuel temperatures }\end{array}$ & \\
\hline \multicolumn{5}{|c|}{ Fuel reaction with water } \\
\hline $\begin{array}{l}\text { Fuel reaction } \\
\text { with water }\end{array}$ & $\begin{array}{l}\text { SA-J-10b } \\
\text { OA-J-10b } \\
\text { WS-J-10b }\end{array}$ & $\begin{array}{l}\text { None at the } \\
\text { CSB } \\
\text { required for } \\
\text { safety }\end{array}$ & $\begin{array}{l}\text { General assumption is that the } \mathrm{MCO} \text { is received within } \\
\text { specifications. } \\
\text { Assumption: } \\
\text { - The K Basins washing process and the drying process at } \\
\text { the CVDF will ensure that the key interface performance } \\
\text { assumptions are met. }\end{array}$ & \\
\hline
\end{tabular}


Table 6-4. Summary of Safety Features Required to Prevent a Multi-Canister Overpack Thermal Runaway. (3 sheets)

\begin{tabular}{|c|c|c|c|c|}
\hline Accident & $\begin{array}{l}\text { Checklist } \\
\text { designator }^{2}\end{array}$ & $\begin{array}{l}\text { General } \\
\text { function }\end{array}$ & Safety features and safety classification ${ }^{b}$ & $\begin{array}{l}\text { NRC ITS } \\
\text { category }\end{array}$ \\
\hline \multicolumn{5}{|c|}{ Fuel exposed to air } \\
\hline $\begin{array}{l}\text { MCO shear } \\
\text { by the MHM } \\
\text { from } \\
\text { rotational or } \\
\text { translational } \\
\text { MHM } \\
\text { movement }\end{array}$ & $\begin{array}{l}\text { Rotational } \\
\text { WS-E-07 } \\
\text { SA-E-07 } \\
\text { OA-E-07 } \\
\\
\text { Translational } \\
\text { WS-F-07 } \\
\text { SA-F-07b } \\
\text { OA-F-07 } \\
\text { SA-F-05 }\end{array}$ & $\begin{array}{l}\text { Prevent } \\
\text { shear of the } \\
\text { MCO }\end{array}$ & 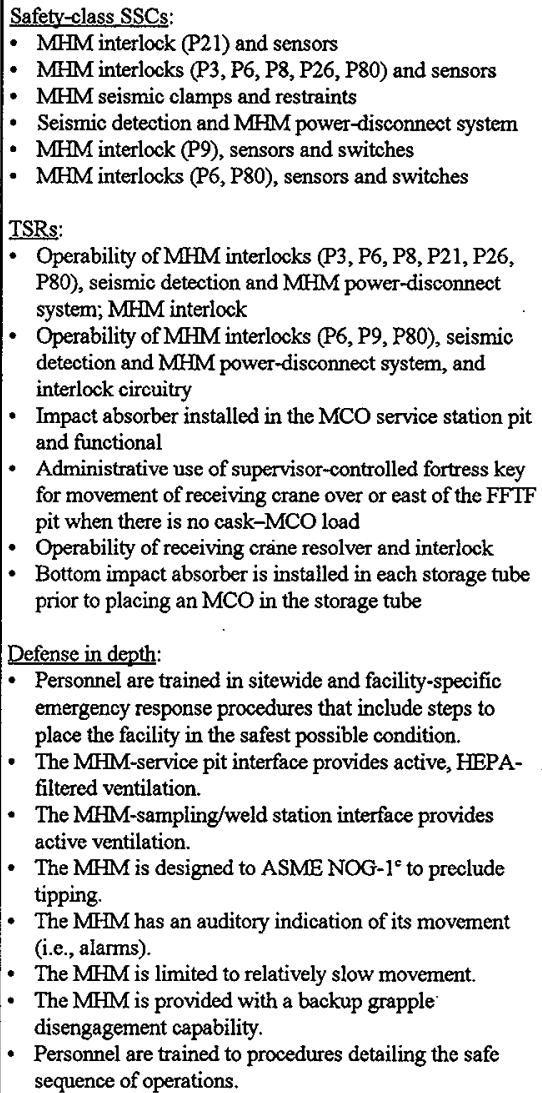 & $\begin{array}{l}\text { NA } \\
\text { NA } \\
\text { NA } \\
\text { NA } \\
\text { NA } \\
\text { NA }\end{array}$ \\
\hline
\end{tabular}


Table 6-4. Summary of Safety Features Required to Prevent a Multi-Canister Overpack Thermal Runaway. (3 sheets)

\begin{tabular}{|c|c|c|c|c|}
\hline Accident & $\begin{array}{c}\text { Checklist } \\
\text { designator }\end{array}$ & $\begin{array}{c}\text { General } \\
\text { function }\end{array}$ & Safety features and safety classification & $\begin{array}{c}\text { NRC ITS } \\
\text { category }^{\mathbf{b}}\end{array}$ \\
\hline
\end{tabular}

${ }^{2}$ Checklist designators are from HNF-SD-SNF-HIE-001, 1999, Canister Storage Building Hazard Analysis Report, Rev. 1, Fluor Daniel Hanford, Incorporated, Richland, Washington.

'Safety classification for DBA in this category. Safety classification or ITS category could be different for another DBA category.

"ASME NOG-1, 1995, Rules for Construction of Overhead and Gantry Cranes (Top Running Bridge, Multiple Girder), American Society of Mechanical Engineers, New York, New York.

$\mathrm{CSB}=$ Canister Storage Building.

$\mathrm{CVDF}=$ Cold Vacuum Drying Facility.

$\mathrm{DBA}=$ design basis accident.

FFTF $=$ Fast Flux Test Facility.

HEPA = high-efficiency particulate air (filter)

ITS $=$ important to safety.

$\mathrm{MCO}=$ multi-canister overpack.

MHM = multi-canister overpack handling machine.

NA $=$ not applicable to ITS category classification.

$\mathrm{NRC}=$ U.S. Nuclear Regulatory Commission. 
from the design basis accident, each scenario and the corresponding controls are also described below.

Complete and partial shears of the $\mathrm{MCO}$ are prevented to protect criticality geometry, as described in Chapter 2.0. Since the maximum allowed outer MCO wall temperatures can be higher than $115^{\circ} \mathrm{C}$, it is most important to prevent MCO shears when rapid fuel-air reactions can occur at fuel temperatures above $125^{\circ} \mathrm{C}$ when oxygen could contact the fuel (equivalent to maintaining the $\mathrm{MCO}$ wall temperature below $115^{\circ} \mathrm{C}$ ). Preventing oxygen from reaching the fuel is accomplished by maintaining the MCO vessel integrity by preventing shears by the MHM. The following are the specific safety features and controls identified in Chapter 2.0 that prevent or mitigate this event (they are included here for completeness):

- Safety-class SSCs

- MHM interlock (P21) and sensors - Ensure that the MCO hoist cannot operate unless the bridge seismic clamps and trolley seismic restraints are applied when an MCO is in the MHM

- . MHM interlocks (P3, P6, P8, P26, P80) and sensors - Prevent the seismic restraints and clamps from disengaging and power being applied to the bridge and trolley drive motors unless the MCO hoist is fully raised when in the $\mathrm{MCO}$ or impact absorber mode or at the tube plug exchange limit when in the tube plug exchange mode; the interlock circuitry includes relays, contactors, and sensors (resolvers, limit switches, photoelectric switches)

- MHM seismic clamps and restraints - Prevent translational or rotational movement of MHM whenever engaged when an MCO is in the MHM (restraints must be engaged prior to MCO hoist operation)

- Seismic detection and MHM power-disconnect system - Detects seismic event (magnitude $0.74 / 3 \mathrm{~g}$ horizontal, $0.49 / 3 \mathrm{~g}$ vertical) and removes all power to the MHM; removal of power prevents operation of the MCO hoist, disengagement of seismic restraints, and MHM translational or rotational movement (MHM interlocks are not seismically qualified)

- MHM interlock (P9), sensors, and switches - Ensure that the MCO hoist cannot operate unless the turret and base locking pins are applied when an MCO is in the MHM; the interlock circuitry includes relays, contactors, and sensors (proximity)

- MHM interlocks (P6, P80), sensors, and switches - Prevent the turret and base locking pins from disengaging and power being applied to the turret rotational drive motors unless the MCO hoist is fully raised when in the MCO or impact absorber mode or at the tube plug exchange limit when in the tube 


\section{SNF-3328 REV 0}

plug exchange mode; the interlock circuitry includes relays, contactors, and sensors (resolver, limit switches, photoelectric switches).

- TSR

- Operability of MHM interlocks (P3, P6, P8, P21, P26, P80) and seismic detection and MHM power-disconnect system; the interlock circuitry includes relays, contactors, and sensors (resolvers, limit switches, photoelectric switches).

- Operability of MHM interlocks (P6, P9, P80) and seismic detection and MHM power-disconnect system; the interlock circuitry includes power contactors, MHM relays, mechanical switches, and sensors (resolvers, limit switches, photoelectric switches).

- Impact absorber is installed in the MCO service station pit and is functional.

- Administrative use of the supervisor-controlled fortress key for movement of receiving crane over or east of the Fast Flux Test Facility pit when there is no cask-MCO loaded with SNF suspended from the crane

- Operability of receiving crane positioning/interlock control system.

- Bottom impact absorber is installed in each storage tube prior to placing an $\mathrm{MCO}$ in the storage tube

All of the hazards in Table 6-4 that are caused by MHM failures are addressed in detail in Chapter 7.0.

\subsection{REFERENCES}

CSB-HV-0014, 1998, Long Term MCO Temperature Without Cooling in the Sampling Station, Fluor Daniel Hanford, Incorporated, Richland, Washington.

DOE-HDBK-3010-94, 1994, Airborne Release Fractions/Rates and Respirable Fractions/Rates for Nonreactor Nuclear Facilities, U.S. Department of Energy, Washington, D.C.

ESL/R(97)009, 1998, Hanford MHM Phase 111 Thermal Assessment of MCO and MHM with Cask Extract System, Rev. 1, ALSTOM Automation Ltd, Leicester, England.

FAI/98-40, 1998, Hanford Spent Nuclear Fuel Safety Analysis Model HANSF 1.2: User's Manual, Rev. 0, Fauske \& Associates, Incorporated, Burr Ridge, Illinois. 
HNF-1523, 1988, K-Basins Particulate Water Content, Behavior, and Impact, Rev. 1, Fluor Daniel Hanford, Incorporated, Richland, Washington.

HNF-1851, 1998, Cold Vacuum Drying Residual Free Water Test Description, Rev. 1, Fluor Daniel Hanford, Incorporated, Richland, Washington.

HNF-2256, 1998, Simulation of Normal and Off-Normal Multi-Canister Overpack Behavior, Rev. 1, Fluor Daniel Hanford, Incorporated, Richland, Washington.

HNF-3035, 1998, MCO Gas Composition for Low Reactive Surface Areas, Rev. OB, Fluor Daniel Hanford, Incorporated, Richland, Washington.

HNF-3312, 1998, MCO Monitoring Activity Description, Rev. 0, Fluor Daniel Hanford, Incorporated, Richland, Washington.

HNF-3354, 1998, MCO Monitoring Issue Closure Package, Rev. 0, Fluor Daniel Hanford, Incorporated, Richland, Washington.

HNF-SD-SNF-CN-023, 1998, Thermal Analysis of Cold Vacuum Drying of Spent Nuclear Fuel, Rev. 1, Fluor Daniel Hanford, Incorporated, Richland, Washington.

HNF-SD-SNF-DR-003, 1998, Multi-Canister Overpack Design Report, Rev. 1, Fluor Daniel Hanford, Incorporated, Richland, Washington.

HNF-SD-SNF-HIE-001, 1998, Canister Storage Building Hazard Analysis Report, Rev. 1, Draft, Fluor Daniel Hanford, Incorporated, Richland, Washington

HNF-SD-SNF-SARR-005, 1998, Multi-Canister Overpack Topical Report, Rev. 1, Fluor Daniel Hanford, Incorporated, Richland, Washington.

HNF-SD-SNF-TI-015, 1998, Spent Nuclear Fuel Project Technical Databook, Rev. 6, Fluor Daniel Hanford, Incorporated, Richland, Washington.

HNF-SD-SNF-TI-040, 1998, MCO Internal Gas Composition and Pressure During Interim Storage, Rev. 2, Fluor Daniel Hanford, Incorporated, Richland, Washington.

$\mathrm{RD} / \mathrm{B} / 6231 / \mathrm{R} 89,1989$, A Review of the Rates of Reaction of Unirradiated Uranium in Gaseous Atmospheres, Central Electricity Generating Board, Berkeley Nuclear Laboratories, Berkeley, California.

SNF-2356, 1998, Spent Nuclear Fuel Project Cold Vacuum Drying Facility Operations Manual, Rev. 0A, Fluor Daniel Hanford, Incorporated, Richland, Washington. 
Figure 6-1. Temperature Versus Time for Multi-Canister Overpack Components for Case 1, CHOT2SCE.

CHOT2SCE: HB FILLED MCO 1.5 atm,25 C,2\% Iteım, UH3-12,U=10, $132 \mathrm{CWall}$
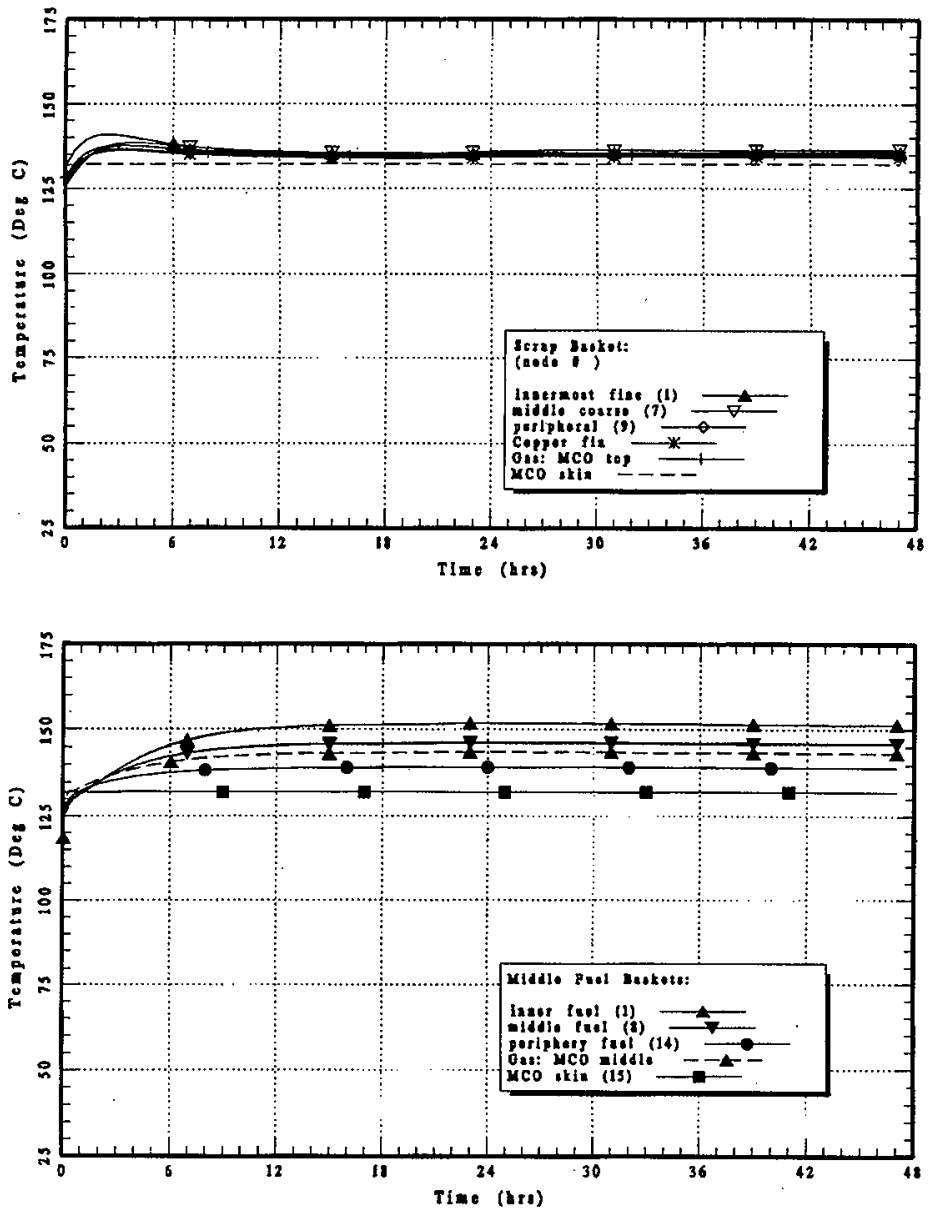
Figure 6-2. Temperature Versus Time for Multi-Canister Overpack Components in Bottom Fuel Basket and Pressure Versus Time for Case 1, CHOT2SCE.
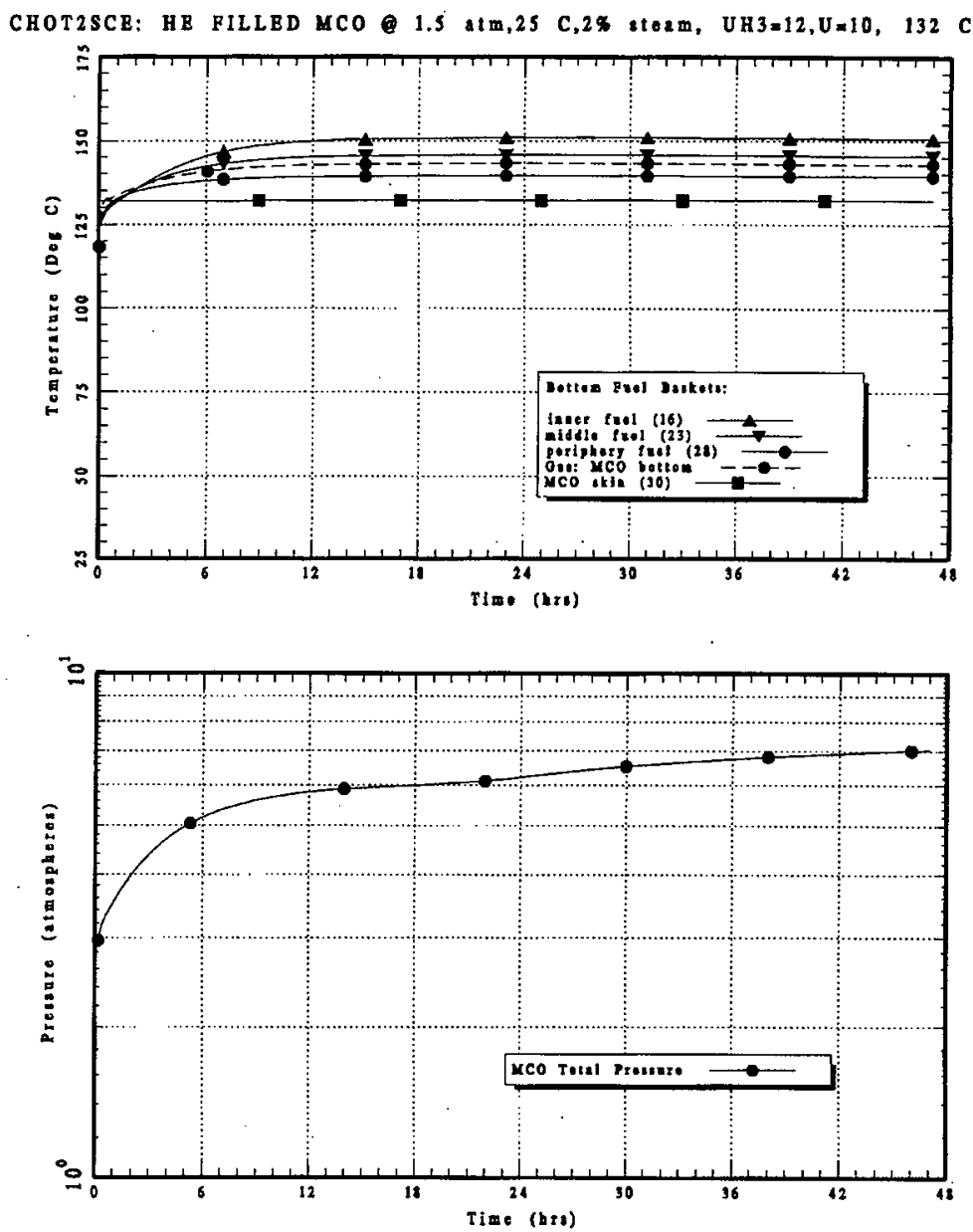
Figure 6-3. Temperature Versus Time for Multi-Canister Overpack Components for Case 2, CHOT2SCR.
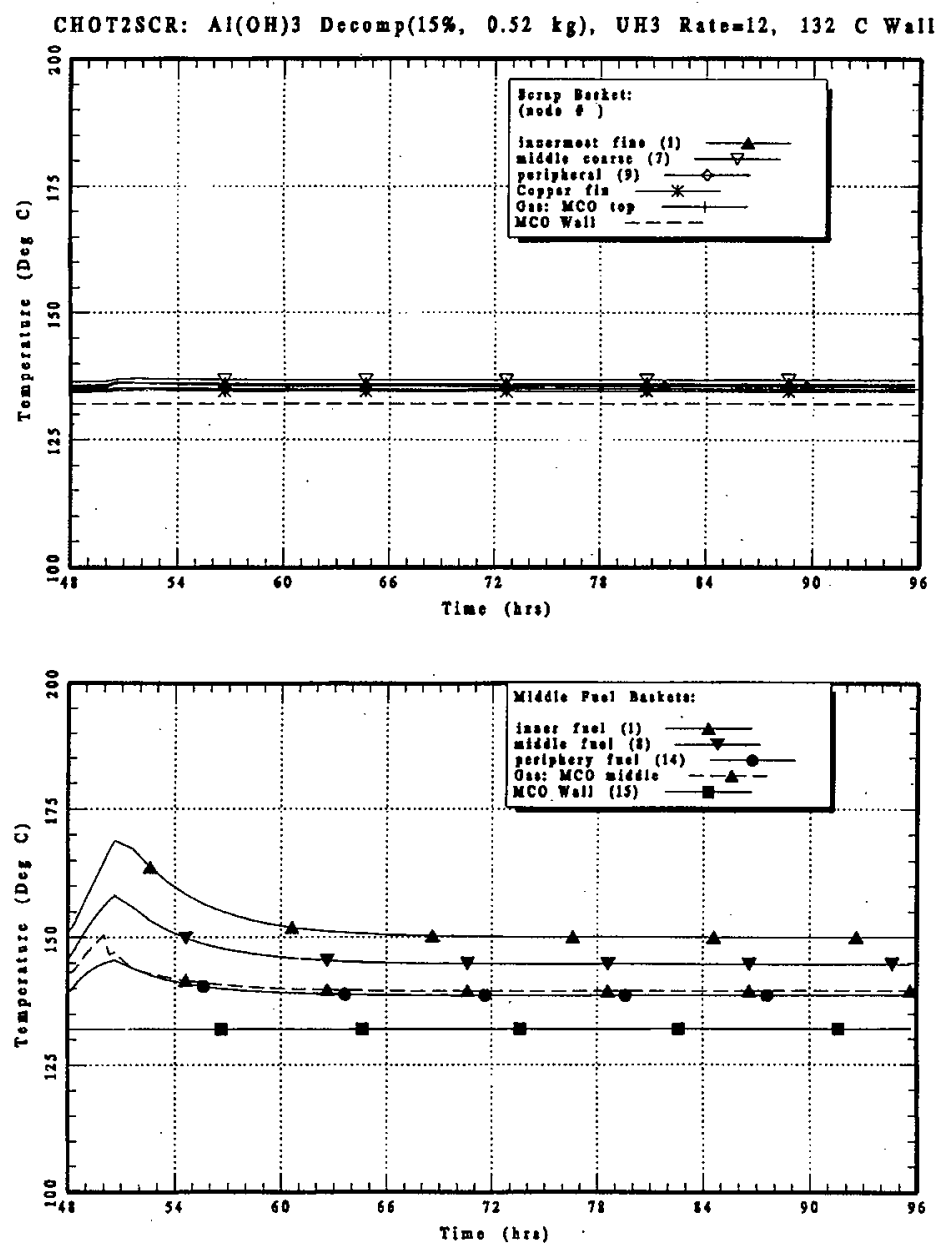
Figure 6-4. Temperature Versus Time for Multi-Canister Overpack Components in Bottom Fuel Basket and Pressure Versus Time for Case 2, CHOT2SCR.
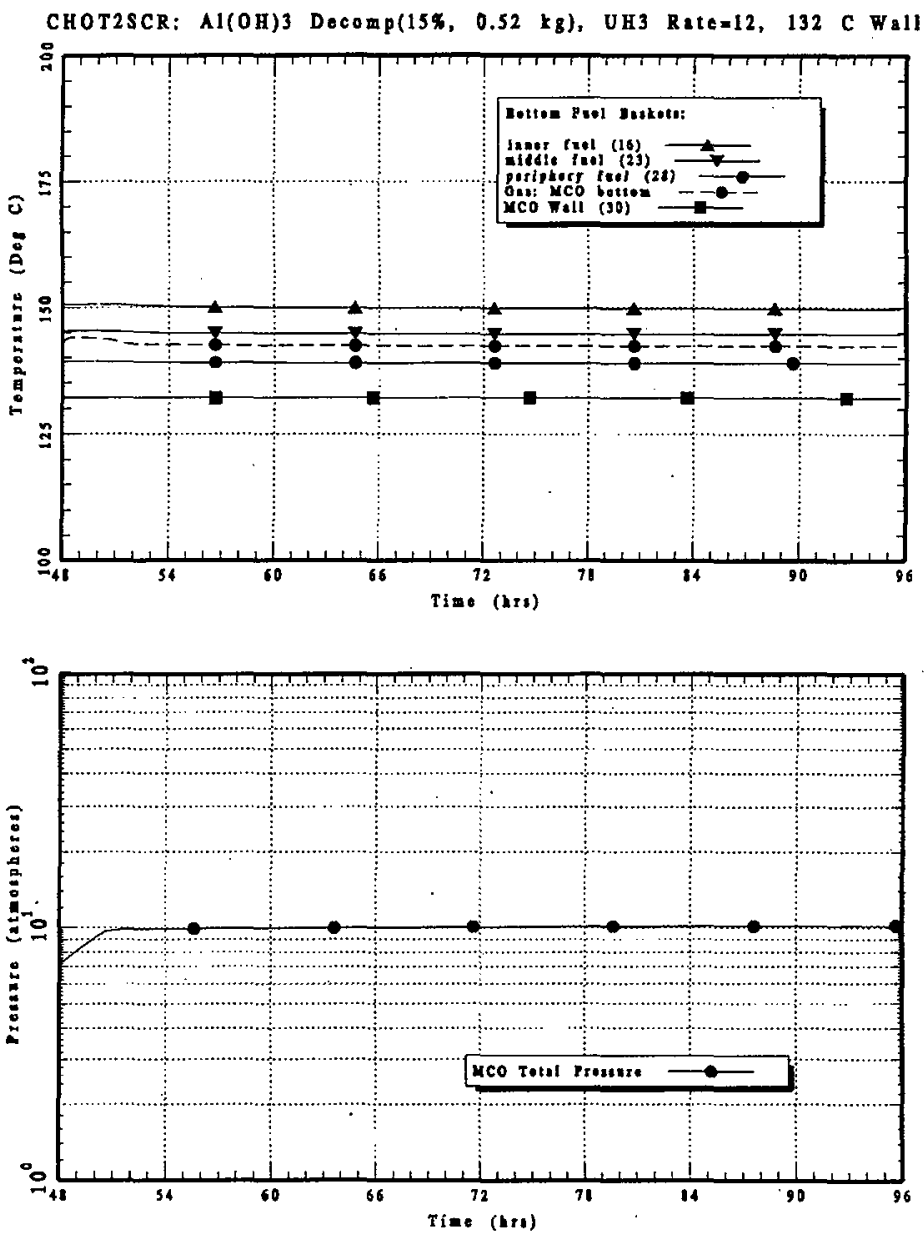
Figure 6-5. Temperature Versus Time for Multi-Canister Overpack for Case 3, COXY2SCE.
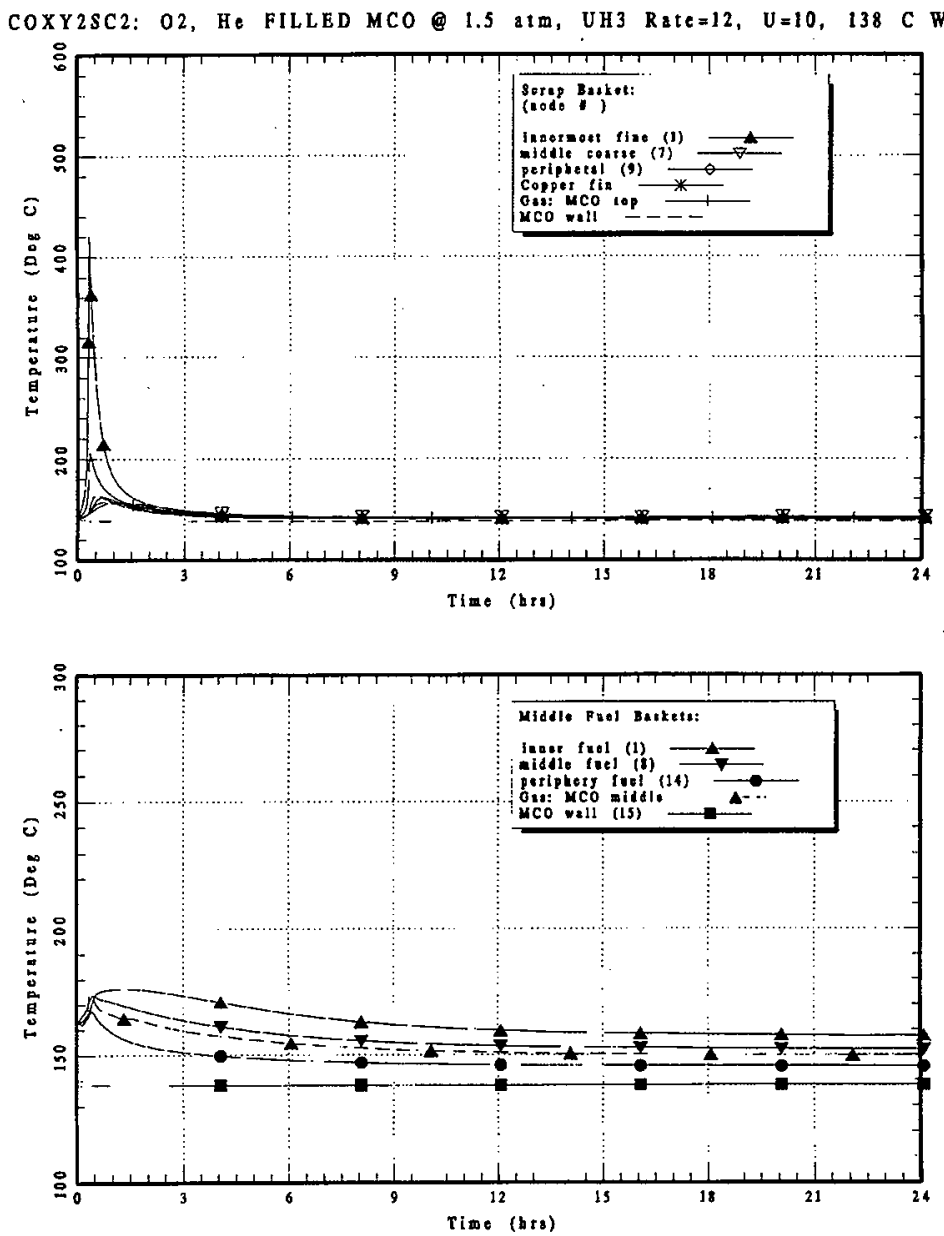
Figure 6-6. Temperature Versus Time for Multi-Canister Overpack Components in Bottom Fuel Basket and Pressure Versus Time for Case 3, COXY2SCE.
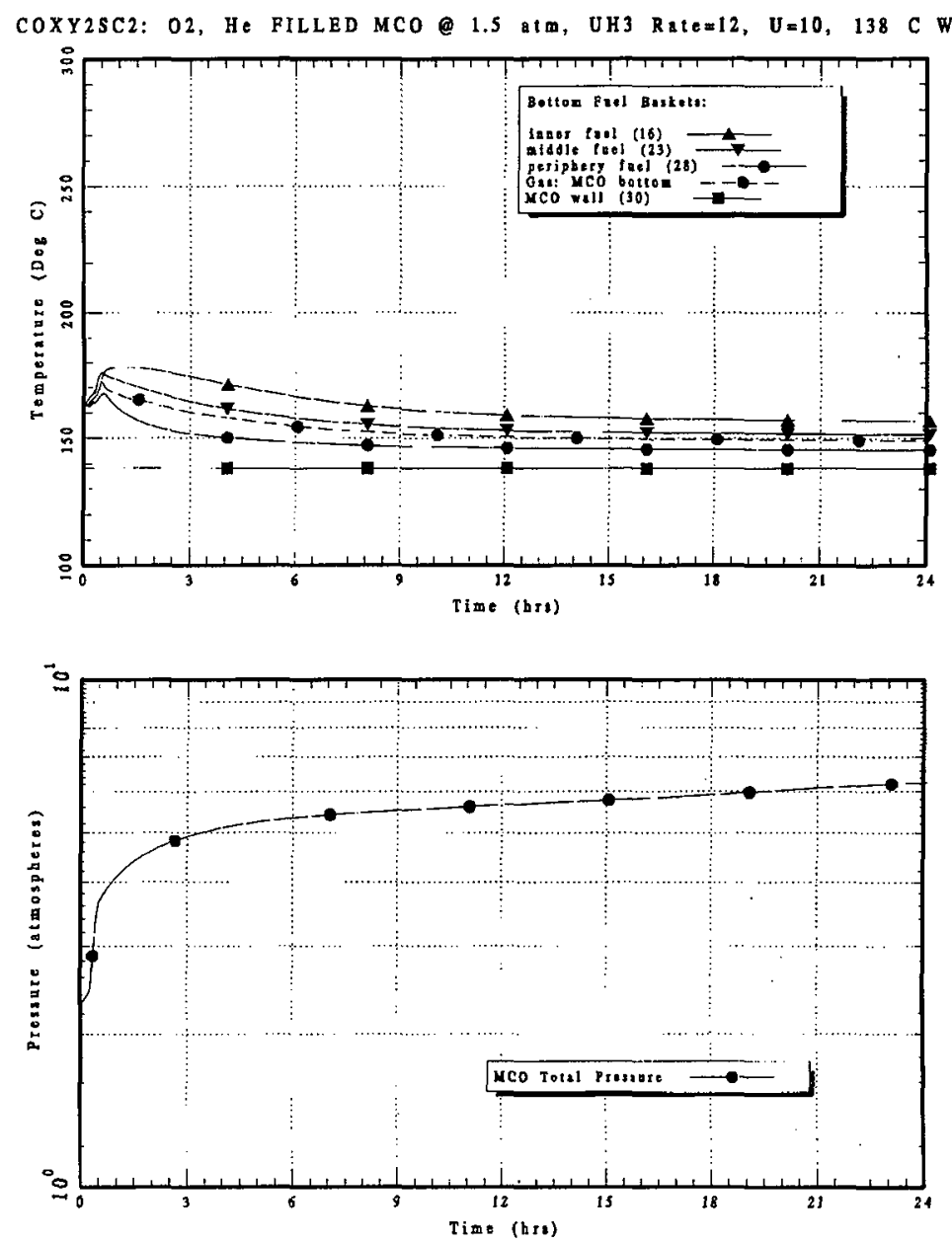
Figure 6-7. Pressure Versus Time for Multi-Canister Overpack for Case 4, CAIR2SC.
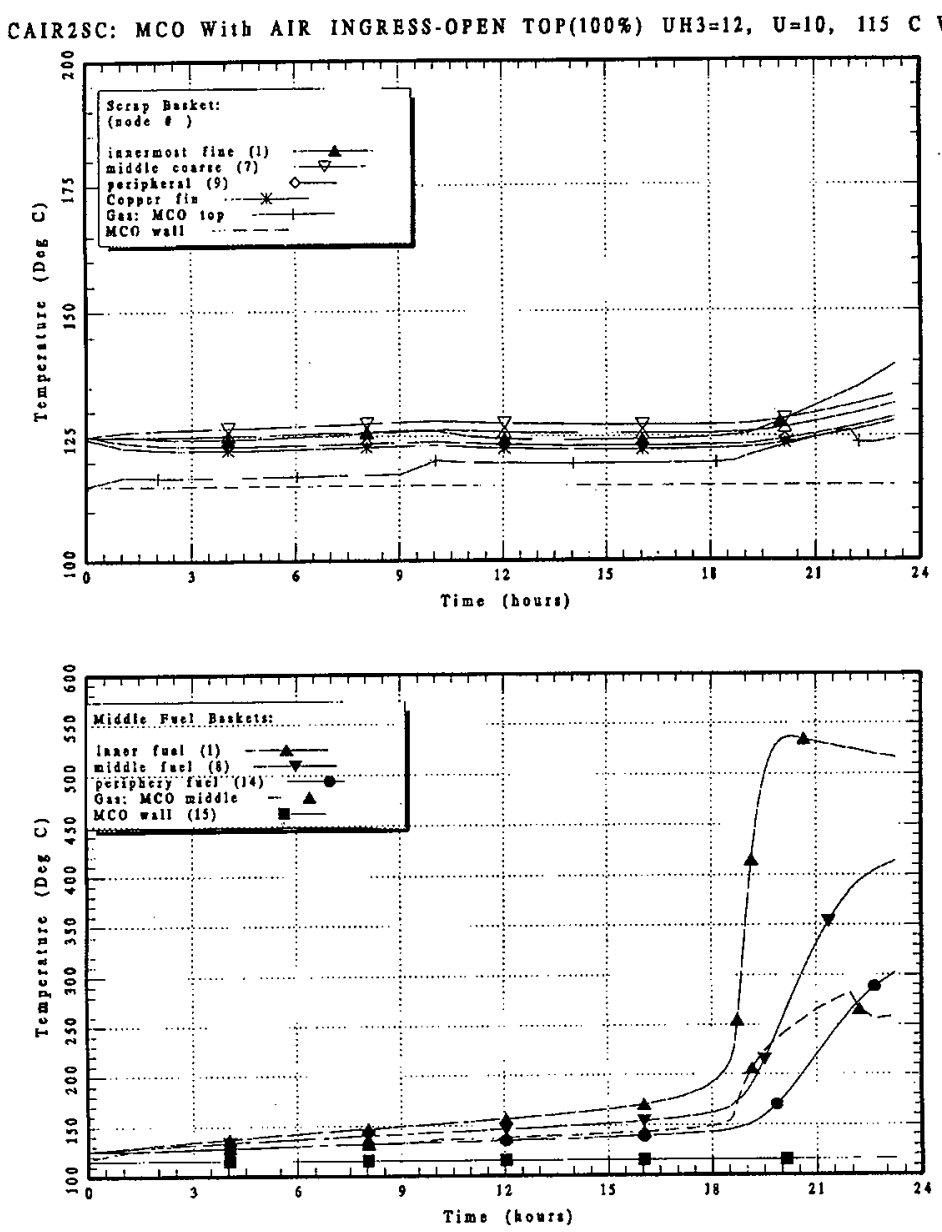
SNF-3328 REV 0

This page intentionally left blank.

snf-3328.06

F6-8 


\subsection{CALCULATIONS FOR VIOLATION OF DESIGN TEMPERATURE CRITERIA}

\subsection{PURPOSE AND OBJECTIVES}

Heat is produced in the multi-canister overpack (MCO) from radioactive decay energy release and energy released from chemical reactions that occur between the fuel and water or gasses. The MCO and Canister Storage Building (CSB) have been designed to provide for ample heat transfer away from the MCO so that an unacceptably high temperature will not be reached during normal handling and storage of the MCO at the CSB. This analysis investigates possible situations where normal heat conduction may be reduced in such a way or for such a length of time as to result in potential overheating of the $\mathrm{MCO}$ and/or surrounding structures. Preventive measures are required to preclude such overheating because it could compromise the safety function of safety components such as the MCO. Required controls to prevent the potential consequences of each overheating condition are summarized in Section 7.6.

\subsection{SCENARIO DEVELOPMENT}

Both radioactive decay and chemical reactions within the MCO generate heat. Two situations in which the heat transfer from the MCO to the outside environment could be reduced enough to lead to violation of temperature criteria have been identified by the CSB hazard analysis (HNF-SD-SNF-HIE-001). The MCO design temperature is $270^{\circ} \mathrm{F}\left(132^{\circ} \mathrm{C}\right)$ (HNF-S-0426). Exceeding this design temperature by more than $212^{\circ} \mathrm{F}\left(100^{\circ} \mathrm{C}\right)$ is not expected to have any adverse safety consequences or to affect maintenance of all MCO safety functions. Maintaining this MCO wall temperature should meet the CSB commitment to limit and "maintain the temperature of the $\mathrm{MCO}$ so that the spent nuclear fuel centerline temperature never exceeds $400^{\circ} \mathrm{F}^{\prime \prime}\left(205^{\circ} \mathrm{C}\right.$ ) (corresponding to $270^{\circ} \mathrm{F}\left[132^{\circ} \mathrm{C}\right] \mathrm{MCO}$ wall temperature) (WHC-S-0425). ACI-349, Code Requirements for Nuclear Safety Related Concrete Structures, concrete can be damaged by long-term exposure (on the order of a week or more) to temperatures above about $150^{\circ} \mathrm{F}\left(66^{\circ} \mathrm{C}\right)$ or by shorter term exposures to temperatures above about $350^{\circ} \mathrm{F}\left(177^{\circ} \mathrm{C}\right)$. The CSB operating deck cannot be allowed to have its structural safety function compromised by long-term exposure to high temperatures.

A possible situation in which unacceptable temperatures may be reached is one in which the MCO is located at the sampling/weld station for an extended period of time without active cooling. Because the MCO is tightly confined at the sampling/weld station, the surrounding steel and concrete could act to insulate it from adequate heat transfer once the thermal heat flux through the immediately surrounding materials has reached equilibrium. Calculations indicate that for a maximum heat generation $\mathrm{MCO}$, it would be possible for the $\mathrm{MCO}$ temperature design criteria to be exceeded in about 50 days without active cooling (CSB-HV-0014). For the temperature criteria to be exceeded, the MCO would have to be located in the sampling/weld station pit for about two months or more, depending upon the surrounding soil moisture content. Wall temperatures above the MCO design criteria do not necessarily damage the safety function 
of the MCO outer wall or cause damage to MCO internals. Boiler and Pressure Vessel Code (ASME 1995) maximum temperature criteria for the steel used in the $\mathrm{MCO}$ is $800^{\circ} \mathrm{F}\left(427^{\circ} \mathrm{C}\right)$; the fuel inside the MCO would not be damaged at this temperature. The fuel inside the MCO will not be damaged until the eutectic melting temperature is reached for uranium with steel (i.e., $\left.1,337^{\circ} \mathrm{F}\left[725^{\circ} \mathrm{C}\right]\right)$. Temperatures above $572{ }^{\circ} \mathrm{F}\left(300^{\circ} \mathrm{C}\right)$ will cause bound water to be released from the aluminum hydroxide on the fuel; this water will react with the uranium, producing additional heat and gas. The MCO fuel centerline temperature will rise above that normally expected when bound water is freed only due to radiolysis. Because there is limited water available from hydrates and because this water will be released gradually with increasing temperature, the heat load from these reactions should not be sufficient to lead to runaway reactions or fuel melting. While such an event would most likely not lead to unacceptable MCO consequences, it is prudent engineering to implement controls to limit the MCO wall temperature below the design temperature.

The other credible situation in which unacceptable wall temperatures may be reached is one in which the passive cooling of the CSB vault is significantly reduced such that the MCOs in interim storage and vault structure overheat. If the vault intake and/or exhaust stacks are partially or fully blocked, then the natural convection of air through the vault will be reduced. Significant blockage of the flow could result from many different, unlikely causes, including debris being trapped in the inlet or frost forming over the inlet. Without the vault convective air cooling, temperatures within the vault could rise above design temperature criteria for both the vault walls and ceiling and also for the MCO centerline. High temperatures could cause the concrete operating deck and vault walls to suffer structural damage, thereby compromising their safety functions. The MCO temperature could exceed design temperature criteria, which could cause loss of MCO safety functions to confine and control the geometry of the spent nuclear fuel.

ACI-349, Appendix A.4, provides limitations for concrete temperatures during normal operation or any long-term period. The temperatures shall not exceed $150^{\circ} \mathrm{F}\left(66^{\circ} \mathrm{C}\right)$ except for local areas, such as around penetrations, which are allowed to have increased temperatures not to exceed $200^{\circ} \mathrm{F}\left(93^{\circ} \mathrm{C}\right)$. For an accident duration or any short-term period, the concrete surface temperature shall not exceed $350^{\circ} \mathrm{F}\left(177^{\circ} \mathrm{C}\right)$.

Bounding calculations that assess the effect of loss or partial loss of vault convective cooling flow upon MCO and vault temperatures have been performed (CSB-HV-0003). These calculations assume that the vault is full of MCOs and that the corresponding total heat load is $191.6 \mathrm{~kW}$. The outside air temperature available to cool the vault is assumed to be $115^{\circ} \mathrm{F}$ $\left(46^{\circ} \mathrm{C}\right)$ and the surrounding ground temperature is assumed to be $60^{\circ} \mathrm{F}\left(16^{\circ} \mathrm{C}\right)$. Given these conditions, the maximum initial temperature of the $\mathrm{MCO}$ wall (with no blockage of vault air flow) is expected to be about $252^{\circ} \mathrm{F}\left(122^{\circ} \mathrm{C}\right)$ and the maximum vault concrete ceiling surface temperature is expected to be $132{ }^{\circ} \mathrm{F}\left(56^{\circ} \mathrm{C}\right)$. CSB-HV-0003 calculations indicate that if the intake stack cross-sectional area is instantly reduced to $25 \%$ of normal (i.e., is $75 \%$ blocked), then the $\mathrm{MCO}$ wall temperature would reach $268^{\circ} \mathrm{F}\left(131^{\circ} \mathrm{C}\right)$ and the ceiling temperature would reach $151^{\circ} \mathrm{F}\left(66^{\circ} \mathrm{C}\right)$ in 72 hours. Both temperatures are continuing to rise. If the vault inlet stack were somehow completely blocked, the $\mathrm{MCO}$ wall temperature would reach the $270^{\circ} \mathrm{F}\left(132^{\circ} \mathrm{C}\right)$ 
CSB limit in about 15 hours and would continue to rise in temperature at a rate of about 1 degree per hour. If $50 \%$ or less of the inlet area were blocked, then it is expected that the vault air flow rate and $\mathrm{MCO}$ and ceiling temperatures would be nearly equal to those expected for zero blockage.

The bottom of the inlet area of the vault intake structure is more than $19 \mathrm{~m}$ above the surrounding grade (H-2-1 19294, H-2-119280). A vertical grating surrounds the opening to the intake stack on four sides. This grating consists of a heavy gauge (0.13-in. wire diameter) interwoven stainless steel screen with 0.75 -in. square openings supported by more widely spaced steel cross members (H-2-119298). The overall dimensions of this grating are about $15.5 \mathrm{ft}$ by $17 \mathrm{ft}$ on two sides and $15.5 \mathrm{ft}$ by $18 \mathrm{ft}$ on two sides, giving a total flow area for all four vertical inlet grates of about 1,080 $\mathrm{ft}^{2}$ (H-2-119294). Inlet air flows through this grating and down the inlet stack to a second horizontal grate (H-2-119282) inside the inlet stack that serves a safeguards and security function. This horizontal grating is composed of a metal lattice with perpendicular members spaced $6 \mathrm{in}$. apart. While it is possible for objects to partially block the intake by accumulating on either of these gratings, objects will not easily be able to reach and accumulate on them. Blowing debris, such as tumbleweeds or garbage, will occasionally be lifted to the height of the upper vertical grating and become lodged.

The intake stack horizontal cross-section is rectangular, with minimum interior dimensions of $16 \mathrm{ft}$ by $10 \mathrm{ft}, 8 \mathrm{in}$. producing a flow area of $172 \mathrm{ft}^{2}(\mathrm{H}-2-119280)$. Because the intake outer grating is open on all sides and the opening is quite large, it is improbable that a significant portion of the intake could become blocked. Over a long period of time, it is conceivable that some debris could accumulate over the opening or pass through the outer grating and accumulate on the inner horizontal grating. Because the openings in the vertical inlet grate are significantly smaller than those of the horizontal grate, it is not considered possible for significant debris to accumulate on the horizontal grate. Because the vertical inlet grating has a total flow area that is more than 6 times that of the horizontal cross-section of the inlet, about $92 \%$ of the vertical grating area must become fully blocked before more than $50 \%$ of the inlet cross-section area will be blocked. Given that such a large percentage of the four-sided vertical inlet must become fully blocked and that this inlet is located at such a great height above the existing grade, it is judged incredible for the inlet to block such that an unacceptable passive cooling condition will exist. While it would be prudent to have an infrequent but regular program to visually inspect the inlet for blockage caused by accumulated debris, no such inspection is relied upon. Such an inspection would also ensure that the vertical screen was still intact, so that large debris could not pass into the stack.

\subsection{SOURCE TERM ANALYSIS}

The two potential scenarios described above could lead to the damage of safety-class equipment or structures such that their safety function could be compromised. HNF-PRO-704, Hazard and Accident Analysis Process - Waiver 1, indicates that safety-class controls are required to prevent conditions that would lead to the damage of safety-class equipment or structures. Because the development of radiological source term and dose consequences could 
not lead to more restrictive safety classification and controls, no source term is developed.

\subsection{CONSEQUENCE ANALYSIS}

At the sampling/weld station, the potential unmitigated consequence is structural damage to the safety-class MCO that could lead to potential failure of the MCO containment. However, the maximum expected MCO temperatures are not sufficient to cause loss of MCO safety function or unacceptable fuel damage. Loss of the vault convective cooling could lead not only to possible MCO structural damage but also to structural damage of the safety-class operating deck and vault walls. Heat could increase in the vault over a long period of time and gradual damage to the vault and operating deck concrete could occur. Heat damage to the concrete would slowly continue once it began. A damaged operating deck may not survive the design basis earthquake, resulting in a possible violation of criticality geometry control of the array of MCOs stored in the vault if the vault were to structurally fail. Ample time would be available to identify and correct any loss of air flow condition in the vault. Because the outer vertical inlet screens are so large and are located so far above the existing grade, it is not considered credible for sufficient blockage of the inlet to occur and result in a temperature violation. These temperature criteria violation scenarios will be prevented so that no safety-class structures or equipment will be damaged.

\subsection{COMPARISON TO GUIDELINES}

Safety-class controls are needed to prevent the two described scenarios, so no comparison to dose consequence guidelines are made.

\subsection{SUMMARY OF SAFETY-CLASS STRUCTURES, SYSTEMS, AND COMPONENTS AND TECANICAL SAFETY REQUIREMENT CONTROLS}

The safety-class structural components that are required to ensure that passive cooling is sufficient to prevent the MCOs or safety-class facility concrete structures from being exposed to temperatures in excess of design criteria are as follows:

- Safety-class structures, systems, and components (SSCs)

- Vault (concrete) - Maintains geometry to provide for passive convective cooling air flow past the storage tubes and for criticality geometry control of the MCOs stored in the tubes

- Vault intake structure - Provides inlet for passive cooling air to the vault, is above grade, and has screened entrances that provide assurance that the inlet will not become significantly obstructed 
- Vault exhaust structure - Provides exit for passive cooling of vault, is above grade, and is designed such that it will not become significantly obstructed

- Storage tubes, tube base assemblies, and carbon steel base slab embeds Provide spacing of MCOs within the vault to ensure that each will be cooled by passive airflow and that the array will be maintained in a critically safe geometry.

Although the consequences of the two accident scenarios damage safety-class equipment or structures, the amount of time available to correct the fault condition justifies having no safetyclass equipment to prevent the scenarios.

The glycol cooling system installed in the sampling/weld station pit is capable of cooling an MCO when the MCO remains in the pit for a longer-than-planned period of time. Ample time exists to restore normal power or to obtain portable backup power following an extended power outage so no dedicated backup power system is required. There would be ample time to either repair the cooling system, implement other cooling measures, or use the MHM to simply remove the MCO from the pit. Because analysis shows that overheating could occur within about 2 months without active cooling, it is advisable that the cooling system be operated whenever an $\mathrm{MCO}$ is present in the pit.

For the second accident, a minimum of 50 days is available. For the first accident, at least 72 hours is available after the intake stack cross-sectional flow area is reduced to $25 \%$ of its full area, a blockage that is not credible for such a large area. While the loss of passive vault cooling would have unacceptable consequences, blockage of more than $92 \%$ of the wall inlet is not considered credible. No controls are required to maintain adequate vault cooling.

The SSCs designated to prevent violation of the design temperature criteria are summarized in Table 7-1. U.S. Nuclear Regulatory Commission important-to-safety category SSCs and defense-in-depth features also are included for each specific accident in Table 7-1. 
Table 7-1. Summary of Safety Features Required to Prevent Violation of Design Temperature Criteria Design Basis Accidents.

\begin{tabular}{|c|c|c|c|c|}
\hline Accident & $\begin{array}{l}\text { Checklist } \\
\text { designator" }\end{array}$ & $\begin{array}{l}\text { General } \\
\text { function }\end{array}$ & Safety features and safety classification ${ }^{b}$ & $\begin{array}{l}\text { NRC ITS } \\
\text { category }\end{array}$ \\
\hline $\begin{array}{l}\text { Loss of } \\
\text { normal vault } \\
\text { cooling leads } \\
\text { to rise in fuel } \\
\text { centerline } \\
\text { temperature } \\
\text { and violation } \\
\text { of MCO and } \\
\text { vault concrete } \\
\text { design } \\
\text { temperature } \\
\text { criteria }\end{array}$ & VL-B-07 & $\begin{array}{l}\text { Maintain } \\
\text { structures and } \\
\text { configuration } \\
\text { required to } \\
\text { maintain } \\
\text { adequate } \\
\text { passive } \\
\text { convective } \\
\text { cooling flow } \\
\text { through the } \\
\text { vault }\end{array}$ & $\begin{array}{l}\text { Safety-class SSCS: } \\
\text { - Vault, vault intake structure (including screen), } \\
\text { vault exhaust structure, carbon steel base slab } \\
\text { embeds, tube base assemblies, and storage tubes } \\
\text { Defense in depth: } \\
\text { Differential temperature monitors are located on } \\
\text { outlet stack and give indication of undesired trends } \\
\text { - Various screens on the inlet and outlet stack reduce } \\
\text { the likelihood of accumulation of debris in the vault }\end{array}$ & A \\
\hline $\begin{array}{l}\text { MCO exceeds } \\
\text { design } \\
\text { temperature } \\
\text { criteria } \\
\text { because of } \\
\text { extended } \\
\text { deployment in } \\
\text { the sampling/ } \\
\text { weld station } \\
\text { pit }\end{array}$ & WS-B-07 & & $\begin{array}{l}\text { Although the MCO could exceed the design } \\
\text { temperature while located in the sampling/weld station } \\
\text { for an extended time, no damage to the MCO or other } \\
\text { nuclear safety consequences would result. } \\
\text { Defense in depth: } \\
\text { Other worker safety programs, such as OSHA, } \\
\text { require that the MCO temperatures are sufficiently } \\
\text { low before the MCO is handled and sampled } \\
\text { - Temperature is checked before contacting the MCO } \\
\text { and before the MCO is sampled } \\
\text { Integrated glycol cooling system is available for } \\
\text { active cooling of MCO in the sampling/weld station }\end{array}$ & \\
\hline
\end{tabular}

'Checklist designators are from HNF-SD-SNF-HIE-001, 1999, Canister Storage Building Hazard Analysis Report, Rev. 1, Fluor Daniel Hanford, Incorporated, Richland, Washington.

${ }^{\text {b}} \mathrm{Safety}$ classification for DBA in this category. Safety classifications or IIS category could be different for another DBA category.

$\mathrm{DBA}=$ design basis accident.

ITS $=$ important to safety.

$\mathrm{MCO}=$ multi-canister overpack.

$\mathrm{NRC}=$ U.S. Nuclear Regulatory Commission.

OSHA = Occupational Safety and Health Administration.

SSC = structure, system, and component. 
SNF-3328 REV 0

\subsection{REFERENCES}

ACI-349, 1985, Code Requirements for Nuclear Safety Related Concrete Structures, American Concrete Institute, Farmington Hills, Michigan.

ASME, 1995, Boiler and Pressure Vessel Code, American Society of Mechanical Engineers, New York, New York.

CSB-HV-0003, 1996, Spent Nuclear Fuel Vault Loss of Cooling Analysis, Fluor Daniel Hanford, Incorporated, Richland, Washington.

CSB-HV-0014, 1998, Long Term MCO Temperature Without Cooling in the Sample Station, Rev. 0, Fluor Daniel Hanford, Incorporated, Richland, Washington.

H-2-119280, 1997, Structural Canister Storage Building Operation Floor Reinforcement Details and Intake Structure Details, Rev. 0, Fluor Daniel Hanford, Incorporated, Richland, Washington.

H-2-1 19282, 1997, Structural Canister Storage Building Intake/Exhaust Security Barrier, Rev. 0, Fluor Daniel Hanford, Incorporated, Richland, Washington.

H-2-119294, 1996, Structural Canister Storage Building Air Intake Steel Structure, Rev. 3, Fluor Daniel Hanford, Incorporated, Richland, Washington.

H-2-119298, 1996, Structural Canister Storage Building Air Intake Steel Details, Rev. 3, Fluor Daniel Hanford, Incorporated, Richland, Washington.

HNF-PRO-704, 1997, Hazard and Accident Analysis Process - Waiver 1, Rev. 0, Fluor Daniel Hanford, Incorporated, Richland, Washington.

HNF-S-0426, 1998, Specification for Spent Nuclear Fuel Multi-Canister Overpack, Rev. 4, Fluor Daniel Hanford, Incorporated, Richland, Washington.

HNF-SD-SNF-HIE-001, 1998, Canister Storage Building Hazard Analysis Report, Rev. 1, Draft, Fluor Daniel Hanford, Incorporated, Richland, Washington.

WHC-S-0425, 1996, Performance Specification for Spent Nuclear Fuel Canister Storage Building, Rev. 2, Westinghouse Hanford Company, Richland, Washington. 
SNF-3328 REV 0

This page intentionally left blank. 


\subsection{CALCULATIONS FOR RECOVERY ACTIONS RELATED TO GASEOUS RELEASES AND EXPLOSIONS FROM OVERPACK STORAGE TUBES}

\subsection{PURPOSE AND OBJECTIVE}

The use of the overpack storage tube assembly (OSTA) and the tube vent and purge cart are related to recovery actions of off-normal multi-canister overpacks (MCOs). Analyses were performed to identify safety functions and classify structures, systems, and components to achieve an appropriate level of defense in depth (to prevent or mitigate the radiological consequences of postulated hazards and accident events to the collocated onsite worker) and worker safety (to reduce exposure to radiation) for the OSTAs and tube vent and purge cart. The results of the hazard evaluation for an off-normal MCO in an overpack storage tube, with support by the tube vent and purge cart, are discussed below.

It is currently anticipated that OSTAs will be used for two types of recovery situations. The first is an off-normal MCO in a cask coming from the Cold Vacuum Drying Facility to the Canister Storage Building (CSB). The second is an off-normal occurrence at the CSB where a normal MCO has sustained an impact, drop, or collision during handling operations. In the former case, an MCO shipped from the Cold Vacuum Drying Facility in its transportation cask is received at the CSB and undergoes normal load-in and load-out MCO operations, which include checking the internal pressure of the transportation cask in the service station pit before removing the cask lid. An off-normal MCO in the cask would be discovered during this check if the cask pressure is measured to be off-normal. In the latter case, the MCO suffers an impact, drop, or collision after the lid is removed from the cask and during subsequent MCO handling operations in the CSB.

Based on hazard evaluations for storage of an off-normal MCO in the overpack storage tubes, the two worst-consequence, unmitigated design basis accidents within the overpack storage tubes involve flammable gas explosions. Hydrogen gas can be generated and accumulate within the MCO. MCO gas pressures are not expected to exceed 5.2 atm during the interim storage time period at the CSB (HNF-SD-SNF-TI-015). If the MCO is dropped or otherwise damaged in a way that could lead one to suspect the loss of integrity of the MCO confinement safety function, the MCO could be placed into an overpack storage tube. An MCO placed in an overpack storage tube will have a loss of gaseous containment or will be physically damaged but currently maintaining gaseous containment. This chapter evaluates the potential consequences of these unique representative and bounding design basis accidents for the overpack storage tubes.

\subsection{SCENARIO DEVELOPMENT}

Once an off-normal occurrence has been confirmed, it is anticipated that CSB operations will initiate recovery actions that begin with a recovery team meeting to assess the occurrence and determine the path forward. The recovery team will be responsible for ensuring worker and 
public health and safety during the handling, stabilization, and final disposition of the off-normal MCO. The preferred planned approach is to move the off-normal MCO for storage in an overpack storage tube. It is assumed that recovery operations will continue until the $\mathrm{MCO}$ has been placed in an overpack storage tube and the tube gas space has been filled with inert gas. Once the tube has been inerted, an MCO is considered to have been placed in a stable configuration so that normal operations can resume. In the present design, the capabilities of the tube vent and purge cart, plug assembly, and other available equipment are to be used to monitor the physical characteristics of an off-normal MCO while outside and inside the OSTA. If an off-normal MCO's characteristics are outside of the bounding parameters identified in HNF-2256, Simulation of Normal and Off-Normal Multi-Canister Overpack Behavior, this MCO is to be considered to pose an unreviewed safety question situation.

Hazards have been identified for the overpack storage tubes (HNF-SD-SNF-HIE-001) that rely on mitigation or prevention related to overpack storage tube or overpack storage tube plug safety functions. The condition of the off-normal MCO is as follows:

- Off-normal MCO is mechanically sealed or weld sealed but may have releases due to lost confinement function of the MCO

- The maximum pressure developed in an MCO (during 40-year storage) will be less than $5.2 \mathrm{~atm}$ (before any gas explosion)

- Limited hydrogen gas generation rate and total generation quantity due to maximum of $200 \mathrm{~g}$ of water from cold vacuum drying processing and $1,190 \mathrm{~g}$ of uranium hydrate water (MCO with two scrap baskets)

- Long-term hydrogen generation rate and release limited to radiolysis of aluminum hydroxide (48 $\mathrm{kg}$ maximum)

- Analysis indicates that a flammable mixture within the OSTA is improbable with inerted tubes

- Inert atmosphere and pressure is periodically monitored.

The hazards associated with the overpack storage tubes are dominated by energy and release mechanisms resulting from pressurized releases into the tubes from the $\mathrm{MCO}$ (hazards OA-B-07, OA-H-06a, OA-H-06b, OA-J-06, OA-M-07, OA-N-01, OA-N-03) (HNF-SD-SNF-HIE-001). Consequently, the bounding and representative design basis event for the OSTA is a gaseous release from the MCO into the OSTA tube. The specific accident scenarios will be described and justified in the following section. Calculated unmitigated dose consequences are compared to guidelines and preventive or mitigative features and controls are discussed. The consequences of each of these accidents is bounded by the bounding risk gaseous release accident described in Chapter 3.0. 


\subsubsection{Gaseous Release Accident}

Three gaseous release accident variations are considered: (1) a pressurized release from the MCO into an inerted overpack storage tube without the tube plug mechanically locked; (2) a pressurized release from the MCO into an inerted overpack storage tube with the tube plug mechanically locked, followed by a failed connection between the tube plug and the tube vent and purge cart; and (3) a pressurized release from the MCO into an air-filled overpack storage tube with the tube plug mechanically locked, followed by an immediate detonation of the flammable gas mixture formed in the overpack storage tube.

It is possible that an MCO accident (e.g., a drop) could damage or weaken a seal on the MCO without leading to an immediate leak. A leak could begin due to handling or increased internal pressure while or shortly after the MCO is placed into the overpack storage tube. The scenario considered will not begin until the $\mathrm{MCO}$ has been placed in the overpack storage tube and the tube plug has been placed in the tube. The overpack storage tube will be filled with helium at a pressure of about $7 \mathrm{lb} / \mathrm{in}^{2}$ after the MCO has been placed in the tube. If the pressurized release occurs after this inerting, no explosion can result and any particulate release will only be due to motive forces from the pressurized gas. The maximum pressure possible inside the MCO prior to this venting is 5.2 atm (HNF-SD-SNF-TI-015). If the pressurized release occurs somewhat rapidly, significant radiological particulate could be entrained and released. The resultant pressure in the overpack storage tube is sufficient to lead to the lifting of the tube plug and a venting of gas and entrained particulate to the operating area. This release and the resultant dose consequence will be considered. Distribution of this particulate could be further enhanced by a subsequent explosion in the tube, if the tube has not yet been inerted. The dose consequences of the release due to both the pressurized gas (with entrained particulate) release into the overpack storage tube and its subsequent ignition will also be considered.

If the gaseous release is contained by the closed, inert gas-filled OSTA, there is still an opportunity for particulate released into the tube to be released into the operating area, if an accident occurs when inerting the tube with the tube vent and purge cart. If the connection between the tube plug and the cart high-efficiency particulate air (HEPA) filter was not properly installed or failed, an unfiltered pressurized release could occur from the overpack storage tube. This release would contain resuspended particulate and any particulate that had not yet settled since the original MCO pressurized release into the tube. This scenario will be considered a unique accident whose unmitigated dose consequences and controls are discussed below.

\subsubsection{Flammable Gas Explosion}

While the MCO is designed to maintain confinement during all credible CSB drop accidents, it is conceivable that an MCO drop accident could cause an immediate breach in the MCO confinement. An MCO whose confinement is breached will possibly be placed into an overpack storage tube. To demonstrate the need for inerting the overpack storage tube, the unmitigated accident assumes that the tube is not filled with inert gas. Hydrogen can continue to be produced 
within the MCO and leak into the tube, mix with air, and form a flammable gas in the overpack storage tube. A worse scenario could result if air entered the MCO through its breach and mixed with hydrogen in the MCO to produce a flammable atmosphere within the MCO. The explosion of this mixture in the MCO could cause greater damage to the MCO confinement and lead to radioactive particulate releases from the $\mathrm{MCO}$. The blast effect would dislodge particulate from the fuel, and the particulate would be carried out of the $\mathrm{MCO}$ as it depressurizes. The pressure generated as a result of such an explosion, $P_{F}$, may be calculated using the equations below (SFPE 1992). The first equation is solved for the final temperature, $T_{F}$, and then this value is used in the ideal gas law to solve for the final pressure.

$$
\mathrm{H} * \mathrm{~N}_{\mathrm{H}_{2} \mathrm{O}}=\int_{\mathrm{T}_{0}}^{\mathrm{T}_{\mathrm{F}}}\left(\underset{\mathrm{i}}{\sum} \mathrm{C}_{\mathrm{v}_{\mathrm{i}}} * \mathrm{~N}_{\mathrm{i}}\right) \mathrm{dT}
$$

and

$$
P_{F}=\frac{n R T_{F}}{V}
$$

where

$$
\begin{aligned}
& \mathrm{H}=\text { heat of formation of water from hydrogen and oxygen } \\
& \mathrm{N}_{\mathrm{H} 2 \mathrm{O}}=\text { the number of moles of water formed } \\
& \mathrm{T}_{0}=\text { the initial temperature of the gas } \\
& \mathrm{T}_{\mathrm{F}}=\text { the final temperature of the gas } \\
& \mathrm{Cv}_{\mathrm{i}}=\text { the specific heat capacity at constant volume of gas I [obtained using a quadratic } \\
& \quad \text { fit as a function of temperature to data from Whitwell and Toner (1969)] } \\
& \mathrm{N}_{\mathrm{i}}=\text { number of moles of gas I after the reaction } \\
& \mathrm{P}_{\mathrm{F}}=\text { final pressure } \\
& \mathrm{n}=\text { total number of moles of gas after the reaction } \\
& \mathrm{R}=\text { the universal gas constant } \\
& \mathrm{V}=\text { the MCO gas volume. }
\end{aligned}
$$

A stoichiometric ratio of hydrogen and oxygen from air is not expected within the MCO because the MCO is filled with helium at the Cold Vacuum Drying Facility, and the production of hydrogen is greatly reduced if oxygen enters the $\mathrm{MCO}$. A leak could develop in the MCO, allowing the helium-hydrogen mixture to escape while hydrogen continues to be produced. After the MCO has depressurized to equilibrium pressure with the tube, air can diffuse into the MCO. If a stoichiometric mixture of oxygen in air with hydrogen is conservatively used to calculate the pressure immediately after ignition, then pressure within the MCO is calculated to be about 8 atm. 
If a detonation occurs, it may lead to an instantaneous over pressure of about 16 atm because of the reflected pressure pulse within the essentially confined MCO. The MCO might sustain additional damage from this explosion, but is expected to substantially withstand this instantaneous over pressure. The blast effect would dislodge particulate from the fuel and the particulate would be carried out of the MCO as it depressurizes. The particulate release from this accident is calculated, and, as expected, is similar to that calculated for the bounding unmitigated gaseous release accident.

The gaseous release accident could also lead to the formation and subsequent explosion of a flammable gas mixture in the overpack storage tube outside of the MCO. The mechanical consequences of and the controls to prevent such an explosion are discussed below.

In summary, the bounding scenario for these accidents describes a pressurized release of gases from an MCO into an overpack storage tube because of either internal MCO pressure or a flammable gas explosion within the $\mathrm{MCO}$. The unmitigated scenario is brought to a stable state by allowing the MCO inside the OSTA and the OSTA to be vented and purged of any additional gas generated. The tube vent and purge cart are used until the MCO in the OSTA and the OSTA are brought to a stable inert atmosphere. Any contamination is cleaned consistent with radiation control procedures. The off-normal $\mathrm{MCO}$ is handled within recovery operations under emergency response procedures, with the preferred approach being to move the off-normal $\mathrm{MCO}$ to another available overpack storage tube for long-term observation and storage.

\subsection{SOURCE TERM DEVELOPMENT AND CONSEQUENCE ANALYSIS}

\subsubsection{Gaseous Release Accident}

The relatively quick venting of a potentially pressurized $\mathrm{MCO}$ in an overpack storage tube would result in radioactive releases comparable to those predicted for the bounding gaseous release accident at the sampling/weld station. The unmitigated radioactive particulate release can be estimated using bounding release fractions derived from experiments in which pressurized gases are vented through powders. The radioactive particulate available for release would be generated by reactions within the MCO that occur after the fuel is washed. Flowing gas exiting the $\mathrm{MCO}$ would sweep past the fuel surfaces and entrain uranium oxide particulate. This particulate must then escape through a torturous path and out a small opening in the MCO or one of its seals to be released to the overpack storage tube.

The bounding airborne release fraction and limiting respirable fraction for this release is based on data reported in DOE-HDBK-3010-94, Airborne Release Fractions/Rates and Respirable Fractions/Rates for Nonreactor Nuclear Facilities, Section 4.4.2.3.2. For pressurized gases less than $0.17 \mathrm{MPa}$ gauge, the airborne release fraction is bounded by $5 \times 10^{-3}$, and the respirable fraction is bounded by a value of 0.4 . The bounding mass of particulate formed in the MCO is about $34 \mathrm{~kg}$ of uranium oxide, comprised of $30 \mathrm{~kg}$ of uranium (HNF-SD-SNF-TI-015). 
The mass of respirable radioactive particulate released $(Q)$ during this venting is calculated using (HNF-SD-SNF-TI-059):

$$
Q=(M A R)(A R F)(R F)(L P F)
$$

where

$$
\begin{aligned}
& \mathrm{MAR}=\text { material at risk }(30 \mathrm{~kg}) \\
& \mathrm{ARF}=\text { airborne release fraction }\left(5.0 \times 10^{-3}\right) \\
& \mathrm{RF}=\text { respirable fraction }(0.4) \\
& \mathrm{LPF}=\text { leak path factor }(\text { conservatively set to } 1) .
\end{aligned}
$$

The amount released into the overpack storage tube during $\mathrm{MCO}$ venting is calculated to be:

$$
\mathrm{Q}=(30 \mathrm{~kg})\left(5.0 \times 10^{-3}\right)(0.4)(1)=0.060 \mathrm{~kg}=60 \mathrm{~g}
$$

The overpack storage tube and tube plug provide passive confinement for gases escaping the $\mathrm{MCO}$; however, the pressure reached in the overpack storage tube would cause the tube plug to momentarily lift so that some portion of the tube gases escapes to the operating area. As the pressurized gas is released from the $\mathrm{MCO}$, it will expand into the overpack storage tube. The overpack storage tube is expected to be at about $7 \mathrm{lb} / \mathrm{in}^{2}$ pressure before this event occurs, if it is backfilled with helium. Given the combined gaseous volume $\left(V_{3}\right)$ in the $\mathrm{MCO}\left(\mathrm{V}_{1}=500 \mathrm{~L}\right)$ and the free space in the overpack storage tube $\left(V_{2} \approx 2,600 \mathrm{~L}\right)$, the equilibrium pressure in both after the gaseous release can be calculated as follows using the ideal gas law.

The total number of moles of gas is:

$$
\mathrm{n}_{3}=\mathrm{n}_{1}+\mathrm{n}_{2}=(5.2 \mathrm{~atm})(500 \mathrm{~L}) /(\mathrm{RT})+(1.48 \mathrm{~atm})(2600 \mathrm{~L}) /(\mathrm{RT})=(6,440 \mathrm{~atm}-\mathrm{L}) /(\mathrm{RT})
$$

where

$\mathrm{n}_{\mathrm{i}}=$ is the number of moles of gas in the $\mathrm{MCO}\left(\mathrm{n}_{1}\right)$, overpack storage tube $\left(\mathrm{n}_{2}\right)$, or combined total $\left(\mathrm{n}_{3}\right)$

$\mathrm{RT}=$ the molar gas constant multiplied by the gas temperature in the MCO and overpack storage tube (assumed to be about the same temperature).

The equilibrium pressure, assuming that no temperature change takes place during venting is:

$$
P_{\text {equil }}=\left(n_{3}\right)(\mathrm{RT}) /(500 \mathrm{~L}+2,600 \mathrm{~L})=(6,440 \mathrm{~atm}-\mathrm{L}) /(3,100 \mathrm{~L})=2.1 \mathrm{~atm}
$$


For the unmitigated accident, the tube plug is not mechanically locked into place. The tube plug has a weight of about $5,300 \mathrm{lb}$ and a surface area exposed to the tube gas space of about $573 \mathrm{in}^{2}$, so that the minimum internal tube pressure required to lift the plug is about $9.3 \mathrm{lb} / \mathrm{in}^{2}$ $(1.6 \mathrm{~atm})$. The overpack storage tube internal pressure must exceed about $1.6 \mathrm{~atm}$ to lift the tube plug so that the seal is broken. The fraction of the overpack storage tube gas released to the operating deck will is calculated:

$$
\text { Gas fraction released }=(2.1 \mathrm{~atm}-1.6 \mathrm{~atm}) / 2.1 \mathrm{~atm}=0.24
$$

If the $60 \mathrm{~g}$ of particulate released from the MCO is spread uniformly in the overpack storage tube gas, then about $24 \%$ of the particulate, or $14 \mathrm{~g}$, is released outside the tube into the building and environment.

If the overpack storage tube were not filled with inert gas then the gas released from the MCO to the overpack storage tube could form a flammable mixture. If this mixture were to detonate then there would be sufficient force to lift the tube plug, permanently breaking the seal (see Section 8.3.2). In this case, all $60 \mathrm{~g}$ of particulate could be released to the environment.

The radiological dose (effective dose equivalent $[\mathrm{EDE}]$ ) to a downwind receptor may be calculated using (HNF-SD-SNF-TI-059):

$$
\mathrm{EDE}=(\mathrm{M})\left(\chi / \mathrm{Q}^{\prime}\right)(\mathrm{BR})(\mathrm{UD})
$$

where

$$
\begin{aligned}
& \mathrm{EDE}=\text { the effective dose equivalent (rem) } \\
& \mathrm{M}=\text { the respirable radioactive particulate released }(\mathrm{g}) \\
& \chi / \mathrm{Q}^{\prime}=\text { the air transport factor }\left(\mathrm{s} / \mathrm{m}^{3}\right) \\
& \mathrm{BR}=\text { the average inhalation rate during the release }\left(\mathrm{m}^{3} / \mathrm{s}\right) \\
& \mathrm{UD}=\text { the committed effective dose equivalent per unit gram }(\mathrm{rem} / \mathrm{g}) \text {. }
\end{aligned}
$$

For this release the appropriate values for the air transport factor $\left(\chi / Q^{\prime}\right)$ are given for release durations from the CSB that are less than one hour. For the onsite receptor $100 \mathrm{~m}$ from the CSB the maximum value for $\chi / Q^{\prime}$ is $3.41 \times 10^{-2} \mathrm{~s} / \mathrm{m}^{3}$, while for the receptor at the Hanford Site boundary the value is $1.30 \times 10^{-5} \mathrm{~s} / \mathrm{m}^{3}$ (HNF-SD-SNF-TI-059). The breathing rate (BR) for a short duration release is $3.33 \times 10^{-4} \mathrm{~m}^{3} / \mathrm{s}$, that of an individual performing light activity (HNF-SD-SNF-TI-059). The unit dose (UD) equivalent for the spent nuclear fuel is $4.38 \times 10^{5} \mathrm{rem} / \mathrm{g}$ (HNF-SD-SNF-TI-059).

For the onsite worker $(100 \mathrm{~m})$, the calculated dose from this gaseous release accident without a subsequent explosion in the tube is:

$$
\begin{aligned}
\mathrm{EDE}_{\text {onsite }} & =(14 \mathrm{~g})\left(3.41 \times 10^{-2} \mathrm{~s} / \mathrm{m}^{3}\right)\left(3.33 \times 10^{-4} \mathrm{~m}^{3} / \mathrm{s}\right)\left(4.38 \times 10^{5} \mathrm{rem} / \mathrm{g}\right) \\
& =70 \mathrm{rem} .
\end{aligned}
$$


The offsite receptor dose from this gaseous release accident without a subsequent explosion in the tube is calculated to be:

$$
\begin{aligned}
\operatorname{EDE}_{\text {offsitc }} & =(14 \mathrm{~g})\left(1.30 \times 10^{-5} \mathrm{~s} / \mathrm{m}^{3}\right)\left(3.33 \times 10^{-4} \mathrm{~m}^{3} / \mathrm{s}\right)\left(4.38 \times 10^{5} \mathrm{rem} / \mathrm{g}\right) \\
& =0.027 \mathrm{rem}
\end{aligned}
$$

If the release is enhanced by an immediate detonation in the overpack storage tube, then both the onsite and offsite releases would increase by about a factor of 6 to 420 rem onsite and $0.16 \mathrm{rem}$ offsite. Such a detonation cannot occur after the tube has been filled with inert gas. The operation of placing the MCO into the overpack storage tube and initially inerting the tube will be considered part of the recovery actions and not part of normal operations as allowed under the CSB Authorization Basis.

If the particulate were fully contained by a sealed OSTA, then the mitigated doses would be zero. There is still a potential for release of a portion of this particulate when the tube vent and purge cart is connected to the tube plug. The tube vent and purge cart would be used to relieve the pressure from the overpack storage tube through HEPA filters so that the potential for pressurized unfiltered relief of the overpack storage tube is reduced. If the filters are specified to operate at a particulate removal efficiency (below 10 microns) of at least $99.9 \%$, then the resultant mitigated doses are reduced by a factor of 1,000 . The onsite $(100 \mathrm{~m})$ mitigated dose from the gaseous release accident (without subsequent flammable gas explosion) is therefore reduced from $70 \mathrm{rem}$ to $0.07 \mathrm{rem}$, which is well below the onsite guideline of $10 \mathrm{rem}$.

If the connection between the tube vent and purge cart and the overpack storage tube plug were to fail during pressure purging, then a release could occur that bypasses the HEPA filters. This failure could occur due to operator error, such as the operator moving the cart with the flexible hose connected to the tube plug. If particulate in the overpack storage tube had settled out of the gas and was distributed on surfaces within the tube, then the pressurized release or particulate from the overpack storage tube would be described by the same bounding release fractions used during the initial release from the $\mathrm{MCO}$. Applying the airborne release fraction of $5 \times 10^{-3}$ and the respirable fraction of 0.4 to the maximum particulate in the tube $(60 \mathrm{~g})$ gives a mass of respirable radioactive particulate released to the environment of $0.12 \mathrm{~g}$. This release will lead to a dose of $0.6 \mathrm{rem}$ to the onsite $(100 \mathrm{~m})$ receptor and to a dose of less than $1 \mathrm{mrem}$ to the offsite receptor. If the particulate in the overpack storage tube has not settled out of the gas before the connection between the tube plug and cart fails, then the release to the operating area could be up to the total particulate $(60 \mathrm{~g})$.

One can determine the approximate time needed for the particulate to settle using a Stokes settling equation for a tranquil gas. For the gas and particulate in the CSB scenario, the terminal settling velocity of the particulate and then the time required to settle may be described by (Hinds 1982, Eq. 3.13): 


$$
\mathrm{V}_{\mathrm{TS}}=\frac{\rho_{\mathrm{p}} \mathrm{d}^{2} \mathrm{~g}}{18 \eta}
$$

where

$$
\begin{aligned}
& \mathrm{V}_{\mathrm{Ts}}=\text { terminal settling velocity }(\mathrm{cm} / \mathrm{s}) \\
& \rho_{\mathrm{p}}=\text { particle density }\left(\mathrm{g} / \mathrm{cm}^{3}\right) \\
& \mathrm{d}=\text { particle diameter }(\mathrm{cm}) \\
& \mathrm{g}=\text { gravitational constant }\left(\mathrm{cm} / \mathrm{s}^{2}\right) \\
& \eta \quad=\text { viscosity of air }\left(\text { dyn } \cdot \mathrm{s} / \mathrm{cm}^{2}\right)
\end{aligned}
$$

and

$$
\mathbf{T}_{\text {setle }}=\frac{\mathbf{H}}{\mathrm{V}_{\mathrm{TS}}}
$$

where

$$
\begin{aligned}
& \mathrm{T}_{\text {setle }}=\text { time required to settle }(\mathrm{s}) \\
& \mathrm{H}=\text { settling height }(\mathrm{cm}) .
\end{aligned}
$$

For 1 micron diameter particulate of density $5 \mathrm{~g} / \mathrm{cm}^{3}$, the terminal settling velocity is given by:

$$
\mathrm{V}_{\mathrm{TS}}=\left(5 \mathrm{~g} / \mathrm{cm}^{3}\right)\left(1 \times 10^{-4} \mathrm{~cm}\right)^{2}\left(980 \mathrm{~cm} / \mathrm{s}^{2}\right) /\left(18 * 1.81 \times 10^{-4} \mathrm{P}\right)=0.015 \mathrm{~cm} / \mathrm{s}
$$

and the corresponding time to settle to the bottom of a $40 \mathrm{ft}$ tall storage tube is:

$$
T_{\text {setle }}=(40 \mathrm{ft})(30.48 \mathrm{~cm} / \mathrm{ft}) /(0.015 \mathrm{~cm} / \mathrm{s})=81280 \mathrm{~s} \approx 23 \mathrm{~h} .
$$

For particulate larger than 1 micron in diameter, the settling time will be less than that calculated for 1 micron. After more than 23 hours after a release into the tube, the particulate will have settled so that it must be resuspended before it could be released.

To determine a reasonable pressure increase that could be expected without a pressurized release during a 24 hour time period one must consider both the maximum hydrogen generation rate from the $\mathrm{MCO}$ and the pressure increase that might be expected from tube temperature changes. After about the first four days that the MCO is sealed at the CVDF, the hydrogen generation gas rate is expected to fall. During the first $3 \times 10^{5}$ seconds the MCO temperature could be expected to rise to $360 \mathrm{~K}$, while the hydrogen concentration climbs to as high as $32 \%$, resulting in a pressure of up to $2.6 \mathrm{~atm}$ (HNF-2256, Appendix T5). The average hydrogen generation rate during this time interval will be higher than the rate at subsequent times under 
normal conditions. The maximum sustained hydrogen gas generation rate from an $\mathrm{MCO}$ at the CSB is about $4.8 \times 10^{-5} \mathrm{moles} / \mathrm{s}$ (HNF-2256). During 24 hours, about 4.15 moles of hydrogen gas may be generated. If the tube contained gas from an MCO that had blown down from $3 \mathrm{~atm}$ internal pressure and the tube was initially pressurized to $4 \mathrm{lb} / \mathrm{in}^{2}$, then at a gas temperature of 313 $\mathrm{K}$ the total number of moles of gas in the storage tube and $\mathrm{MCO}$ would be about 190 . Adding about 4 moles of gas to this system would raise the pressure by about $2 \%$, from about $8.1 \mathrm{lb} / \mathrm{in}^{2}$ gauge to $8.2 \mathrm{lb} / \mathrm{in}^{2}$ gauge. If the temperature of the gas in the tube were to rise about $25 \mathrm{~K}$ during this time period, then the pressure would rise about an additional $8 \%$ to about $8.9 \mathrm{lb} / \mathrm{in}^{2}$ gauge. These changes are calculated to represent typical tube pressure changes that could occur from large temperature changes and large normal hydrogen gas generation rates. Given that one might reasonably expect the tube pressure to rise up to about $1 \mathrm{lb} / \mathrm{in}^{2}$ gauge during a nearly worst-case 24-hour time period, a pressure rise much greater than $1 \mathrm{lb} / \mathrm{in}^{2}$ gauge could indicate a pressurized release that could suspend significant particulate. If the temperature of the tube gas were to drop during the 24-hour time period, then a gaseous release from the MCO would be partially masked by the competing temperature induced pressure drop. Any significant pressurized release from the $\mathrm{MCO}$ would still produce a final pressure more than $1 \mathrm{lb} / \mathrm{in}^{2}$ gauge above that measured about 24 hours previously.

\subsubsection{Flammable Gas Explosion}

Without mitigation, a flammable hydrogen gas mixture can form within the $\mathrm{MCO}$ and/or the overpack storage tube. If a detonation occurs within the $\mathrm{MCO}$, it can lead to an instantaneous overpressure of about $16 \mathrm{~atm}$, due to the reflected pressure pulse wave within the essentially confined MCO. The blast effect would dislodge particulate from the fuel, and the particulate would be carried out of the $\mathrm{MCO}$ as it depressurized. The airborne release fraction and the respirable fraction recommended as bounding for this accident in Section 5.3.2.2 of DOE-HDBK-3010-94 are identical to those used in the gaseous release accident. The amount of particulate released to the inside of the overpack storage tube will be $60 \mathrm{~g}$. The difference in the calculated release will be due to the increase in the fraction of gas that escapes the overpack storage tube after the explosion. The tube initial pressure (before the explosion) will be assumed to be atmospheric because the tube is assumed to be filled with air so that an explosion is possible. Although a detonation could occur within the MCO, the actual overpressure within the MCO just after the explosion will be $8 \mathrm{~atm}$ with an internal gas temperature of $2700 \mathrm{~K}$. Assuming that no gas temperature change takes place during MCO venting to the tube following the explosion, the resultant equilibrium pressure in the tube and MCO may be calculated.

If the MCO pressure after the explosion is $8 \mathrm{~atm}$, then the total number of moles of gas is:

$$
\mathrm{n}_{3}=\mathrm{n}_{1}+\mathrm{n}_{2}=(8 \mathrm{~atm})(500 \mathrm{~L}) /(\mathrm{R} \cdot 2700 \mathrm{~K})+(1.0 \mathrm{~atm})(2,600 \mathrm{~L}) /(\mathrm{R} \cdot 370 \mathrm{~K})=(8.5 \mathrm{~atm}-\mathrm{L} / \mathrm{K}) / \mathrm{R} \text {. }
$$

Gas temperature, ignoring heat loss and differences in gas heat capacities, will be about $800 \mathrm{~K}$. The maximum tube pressure is:

$$
\mathrm{P}=\left(\mathrm{n}_{3}\right)(\mathrm{R} \cdot 800 \mathrm{~K}) /(500 \mathrm{~L}+2,600 \mathrm{~L})=(8.5 \mathrm{~atm}-\mathrm{L} / \mathrm{K})(800 \mathrm{~K}) /(3,100 \mathrm{~L})=2.2 \mathrm{~atm} .
$$


The overpack storage tube internal pressure must exceed about 1.6 atm to lift the tube plug so that the seal is broken. The fraction of the overpack storage tube gas released to the operating deck is calculated:

$$
\text { Gas fraction released }=(2.2 \mathrm{~atm}-1.6 \mathrm{~atm}) / 2.2 \mathrm{~atm}=0.27
$$

If the $60 \mathrm{~g}$ of particulate released from the MCO is spread uniformly in the overpack storage tube gas, then about $27 \%$ of the particulate, or $16 \mathrm{~g}$, is released outside the tube into the building and environment.

For the onsite worker $(100 \mathrm{~m})$, the calculated dose from this accident is:

$$
\begin{aligned}
\operatorname{EDE}_{\text {orsite }} & =(16 \mathrm{~g})\left(3.41 \times 10^{-2} \mathrm{~s} / \mathrm{m}^{3}\right)\left(3.33 \times 10^{-4} \mathrm{~m}^{3} / \mathrm{s}\right)\left(4.38 \times 10^{5} \mathrm{rem} / \mathrm{g}\right) \\
& =81 \mathrm{rem} .
\end{aligned}
$$

The offsite receptor dose is calculated to be:

$$
\begin{aligned}
\mathrm{EDE}_{\text {offsite }} & =(16 \mathrm{~g})\left(1.30 \times 10^{-5} \mathrm{~s} / \mathrm{m}^{3}\right)\left(3.33 \times 10^{-4} \mathrm{~m}^{3} / \mathrm{s}\right)\left(4.38 \times 10^{5} \mathrm{rem} / \mathrm{g}\right) \\
& =0.031 \mathrm{rem} .
\end{aligned}
$$

\subsection{CONSEQUENCE ANALYSIS}

\subsubsection{Gaseous Release Accident}

The overpack storage tube and tube plug provide passive confinement for gases escaping the MCO; however, the pressure reached in the overpack storage tube would cause the tube plug to momentarily lift so that some portion of the tube gases escapes to the operating area. As the pressurized gas is released from the $\mathrm{MCO}$, it will expand into the overpack storage tube. The overpack storage tube is backfilled with helium it is expected to be at a minimum of $4 \mathrm{lb} / \mathrm{in}^{2}$ gauge pressure before this event occurs. Given the combined gaseous volume $\left(\mathrm{V}_{3}\right)$ in the $\mathrm{MCO}$ $\left(V_{1}=500 \mathrm{~L}\right)$ and the free space in the overpack storage tube $\left(\mathrm{V}_{2} \approx 2,600 \mathrm{~L}\right)$, the equilibrium pressure in both after the gaseous release, using the ideal gas law, is about $2.1 \mathrm{~atm}$.

The overpack storage tube internal pressure must exceed about $1.6 \mathrm{~atm}$ to lift the tube plug so that the seal is broken. The fraction of the overpack storage tube gas released to the operating deck is 0.24 . If the $60 \mathrm{~g}$ of particulate released from the MCO is spread uniformly in the overpack storage tube gas, about $24 \%$ of the particulate, or $14 \mathrm{~g}$, is released outside the tube into the building and environment. 


\section{SNF-3328 REV 0}

If the overpack storage tube is not filled with inert gas, the gas released from the MCO to the overpack storage tube could form a flammable mixture. If this mixture detonates, there would be sufficient force to lift the tube plug, permanently breaking the seal (see flammable gas explosion discussion that follows). In this case, all $60 \mathrm{~g}$ of particulate could be released to the environment.

The radiological dose (effective dose equivalent) to a downwind receptor can be calculated using (HNF-SD-SNF-TI-059);

$$
\mathrm{EDE}=(\mathrm{M})\left(\chi / \mathrm{Q}^{\prime}\right)(\mathrm{BR})(\mathrm{UD})
$$

where

$\mathrm{EDE}=$ the effective dose equivalent (rem)

$M=$ the respirable radioactive particulate released $(\mathrm{g})$

$\chi / Q^{\prime}=$ the air transport factor $\left(\mathrm{s} / \mathrm{m}^{3}\right)$

$\mathrm{BR}=$ the average inhalation rate during the release $\left(\mathrm{m}^{3} / \mathrm{s}\right)$

UD = the committed effective dose equivalent per unit gram (rem/g).

For this release, the appropriate values for the air transport factor $\left(\chi / Q^{\prime}\right)$ are given for release durations from the CSB that are less than one hour. For the onsite receptor $100 \mathrm{~m}$ from the CSB, the maximum value for $\chi / Q^{\prime}$ is $3.41 \times 10^{-2} \mathrm{~s} / \mathrm{m}^{3}$. The value for the receptor at the Hanford Site is $1.30 \times 10^{-5} \mathrm{~s} / \mathrm{m}^{3}$ (HNF-SD-SNF-TI-059). The breathing rate (BR) for a short duration release is $3.33 \times 10^{-4} \mathrm{~m}^{3} / \mathrm{s}$, that of an individual performing light activity (HNF-SD-SNF-TI-059). The unit dose (UD) equivalent for the spent nuclear fuel is $4.38 \times 10^{5} \mathrm{rem} / \mathrm{g}$ (HNF-SD-SNF-TI-059).

For the onsite worker $(100 \mathrm{~m})$, the calculated dose from this gaseous release accident without a subsequent explosion in the tube is:

$$
\begin{aligned}
\mathrm{EDE}_{\text {onsite }} & =(14 \mathrm{~g})\left(3.41 \times 10^{-2} \mathrm{~s} / \mathrm{m}^{3}\right)\left(3.33 \times 10^{-4} \mathrm{~m}^{3} / \mathrm{s}\right)\left(4.38 \times 10^{5} \mathrm{rem} / \mathrm{g}\right) \\
& =70 \mathrm{rem} .
\end{aligned}
$$

If the release is enhanced by an immediate detonation in the overpack storage tube, then both the onsite and offsite releases would be increased by about a factor of 7 , to 490 rem onsite and 0.18 rem offsite. This detonation could not occur after the tube has been filled with inert gas. The operation of placing the $\mathrm{MCO}$ into the overpack storage tube and initially inerting the tube will be considered part of the recovery actions and not part of normal operations.

If the particulate is fully contained by a sealed OSTA, the mitigated doses would be zero. There is still a potential for release of a portion of this particulate when the tube vent and purge cart is connected to the tube plug. The tube vent and purge cart would be used to relieve the pressure from the overpack storage tube through HEPA filters, so that the potential for pressurized unfiltered relief of the overpack storage tube is reduced. If the filters are specified to operate at a particulate removal efficiency (below $10 \mu \mathrm{m}$ ) of at least $99.9 \%$, the resultant 
mitigated doses are reduced by a factor of 1,000 . The onsite $(100 \mathrm{~m})$ mitigated dose from the gaseous release accident (without subsequent flammable gas explosion) is therefore reduced from $70 \mathrm{rem}$ to $0.07 \mathrm{rem}$, which is well below the onsite guideline of $10 \mathrm{rem}$.

If the connection between the tube vent and purge cart and the overpack storage tube plug fails during pressure purging, a release could occur that bypasses the HEPA filters. This failure could occur due to operator error (e.g., the operator moving the cart with the flexible hose connected to the tube plug). If particulate in the overpack storage tube had settled out of the gas and was distributed on surfaces within the tube, the pressurized release of particulate from the overpack storage tube would be described by the same bounding release fractions used during the initial release from the MCO. Applying the airborne release fraction of $5 \times 10^{-3}$ and the respirable fraction of 0.4 to the maximum particulate in the tube $(60 \mathrm{~g})$ gives a $0.12 \mathrm{~g}$ mass of respirable radioactive particulate released to the environment. This release will lead to a dose of 0.6 rem to the onsite $(100 \mathrm{~m})$ receptor and to a dose of less than $1 \mathrm{mrem}$ to the offsite receptor. If the particulate in the overpack storage tube has not settled out of the gas before the connection between the tube plug and cart fails, the release to the operating area could be up to the total particulate $(60 \mathrm{~g})$. In this case, the quick-disconnect valve, flexible connection hose, cart piping from the connecting hose to the HEPA filter on the cart, and the HEPA filter are safety-significant preventive and mitigative features on the tube vent and purge cart.

An additional mitigation consideration is particulate settling. The approximate time needed for the particulate to settle can be determined using a Stokes settling equation for a tranquil gas. For the gas and particulate in the CSB scenario, the terminal settling velocity of the particulate and the time required to settle are determined. For a $1-\mu \mathrm{m}$-diameter particulate of density $5 \mathrm{~g} / \mathrm{cm}^{3}$, the time to settle to the bottom of a 40 -ft-tall overpack storage tube is about 23 hours. For particulate larger than $1 \mu \mathrm{m}$ in diameter, the settling time will be less than that calculated for $1 \mu \mathrm{m}$.

The tube vent and purge cart will be connected to the overpack storage tube plug to reinert the tube if the pressure in the tube falls below or above a predetermined range. A pressurized release from an $\mathrm{MCO}$ could occur at any time. If such a release has occurred and led to an increase overpack storage tube pressure, then it is unlikely that another quick release will occur. If the tube pressure has fallen below the specified range and a release is not known to have occurred, then a release is still possible. A similar event could occur at the MCO service station when this station is used to vent and purge a high-pressure cask. A high-pressure cask is considered an off-normal situation in which the MCO seal may be breached. Accordingly, the MCO service station's connecting valve, connecting hose, associated piping to the HEPA filter, and the HEPA filter are safety significant for worker safety.

\subsubsection{Flammable Gas Explosion}

Without mitigation, a flammable hydrogen gas mixture can form within the MCO and/or the overpack storage tube. A stoichiometric ratio of hydrogen and oxygen from air is not expected within the $\mathrm{MCO}$, as the $\mathrm{MCO}$ is filled with helium at the Cold Vacuum Drying Facility and the 
production of hydrogen is greatly reduced if oxygen enters the MCO. A leak could develop in the $\mathrm{MCO}$ and allow the helium-hydrogen mixture to escape while hydrogen continues to be produced. Air can diffuse into the $\mathrm{MCO}$ after the $\mathrm{MCO}$ has depressurized to equilibrium pressure with the tube. If a stoichiometric mixture of oxygen in air with hydrogen is conservatively used to calculate the pressure immediately after ignition, the pressure within the $\mathrm{MCO}$ is calculated to be about $8 \mathrm{~atm}$. If a detonation occurs, it can lead to an instantaneous overpressure of about $16 \mathrm{~atm}$, due to the reflected pressure pulse wave within the essentially confined MCO. The MCO might sustain additional damage from this explosion, but is expected to substantially withstand this instantaneous overpressure. If about $14 \mathrm{~g}$ of particulate are released from the overpack storage tube to the environment, then dose consequences may be calculated as shown in the following example.

For the onsite worker $(100 \mathrm{~m})$, the calculated dose from this accident is

$$
\begin{aligned}
\mathrm{EDE}_{\text {orsite }} & =(14 \mathrm{~g})\left(3.41 \times 10^{-2} \mathrm{~s} / \mathrm{m}^{3}\right)\left(3.33 \times 10^{-4} \mathrm{~m}^{3} / \mathrm{s}\right)\left(4.38 \times 10^{5} \mathrm{rem} / \mathrm{g}\right) \\
& =71 \mathrm{rem} .
\end{aligned}
$$

It is possible for a hydrogen gas mixture to ignite within the overpack storage tube that is not inerted rather than within the MCO. This explosion would not necessarily lead to a significant radiological release, but would lead to large mechanical forces being applied to the OSTA. This scenario could result if hydrogen slowly escapes from the $\mathrm{MCO}$ into the tube and ignites.

Because the tube plug could be sealed and mechanically locked into place, the pressure in the tube could be as high as $2.1 \mathrm{~atm}$ before the ignition. With a $2.1 \mathrm{~atm}$ starting pressure in the overpack storage tube the explosion could lead to a detonation pressure pulse of about $30 \mathrm{~atm}$ in the overpack storage tube. The tube design pressure is 7.5 atm and its working pressure is $52 \mathrm{~atm}$ (CSB-RM-0011). The tube plug lockdown device design pressure is $6.1 \mathrm{~atm}$ and its working pressure is about $27 \mathrm{~atm}$. The tube plug will lift at a pressure of $1.6 \mathrm{~atm}$ if the lockdown device is not applied, and also at a pressure below the failure pressure of the tube if the plug mechanically locked into place. The tube would not suffer significant structural damage that would prevent it from continuing to perform its safety-class structural functions even if a detonation caused it to lose gaseous containment.

\subsection{COMPARISON TO GUIDELINES}

The unmitigated gaseous release accidents and the unmitigated hydrogen explosion accidents result from the MCO being damaged. The most likely cause of this damage is a drop of the MCO. Analysis for credible MCO drops has indicated that it is not possible for the a drop to cause an MCO to lose gaseous confinement if the MCO mechanical seal is of expected quality and is properly assembled. The bounding annual frequency for either the gaseous release or hydrogen explosion accident is estimated to be $1 \times 10^{-4} /$ year, which is categorized into the unlikely event category. Unlikely events are those in which the annual frequency of occurrence is between $1.0 \times 10^{-2}$ and $1.0 \times 10^{-4}$. For unlikely events, the radiological onsite risk evaluation guideline is 10 rem and the offsite accident release limit is 5 rem (Sellers 1997). Both the unmitigated 


\section{SNF-3328 REV 0}

gaseous release accidents and the unmitigated hydrogen explosion accidents result in onsite dose consequences that exceed onsite guidelines. Neither of these accidents lead to offsite dose consequences in excess of the limits.

The gaseous release accident, without subsequent flammable gas explosion, can be prevented or at least mitigated by requiring the OSTA to act as a secondary confinement to the MCO. The overpack storage tube and tube plug must be able to confine a pressurized gas to at least $2.1 \mathrm{~atm}$. If the overpack storage tube and tube plug are designed to maintain gaseous confinement at a suitable pressure above $2.1 \mathrm{~atm}$, the immediate release will be prevented. The tubes are designed to withstand a pressure in excess of $7 \mathrm{~atm}$. The tube plugs are sealed and have lockdown devices that hold the plug seal in place for internal tube pressures up to at least $6.1 \mathrm{~atm}$ ( $75 \mathrm{lb} / \mathrm{in}^{2}$ gauge). If this lockdown device is in place, the tube will be sealed and no release will result from this accident.

A gaseous release accident followed by a flammable gas explosion in the overpack storage tube is precluded if the tube has been filled with inert gas. A similar risk of gaseous release and subsequent flammable gas explosion could occur at any time until the MCO is placed in the overpack storage tube and the tube is inerted. After the accident and until the $\mathrm{MCO}$ handling machine places the MCO in an overpack storage tube and the tube is inerted is considered an accident recovery time period. Appropriate accident mitigation or prevention will be determined by an accident recovery team during recovery. The gaseous release accident followed by a flammable gas explosion in the overpack storage tube is prevented by maintaining an inert environment in the tube.

After a gaseous release accident in the overpack storage tube, the tube vent and purge cart would be used to relieve the pressure from the tube through HEPA filters to reduce the potential for pressurized unfiltered relief of the overpack storage tube. If the filters are specified to operate at a particulate removal efficiency (below $10 \mu \mathrm{m}$ ) of at least $99.9 \%$, the resultant mitigated doses are reduced by a factor of 1,000 . The onsite $(100 \mathrm{~m})$ mitigated dose from the gaseous release accident is therefore reduced from 70 rem to $0.07 \mathrm{rem}$, which is well below the onsite guideline of $10 \mathrm{rem}$. These mitigated dose consequences would also be applicable to a scenario where the $\mathrm{MCO}$ depressurized during the inerting operation using the cart. A summary of the doses expected from the MCO gaseous release accident and comparison to guidelines is given in Table 8-1.

If a gaseous release occurs from an $\mathrm{MCO}$ and the tube vent and purge cart inerting line connected to the tube plug fails, the unmitigated (Table 8-1) MCO gaseous release accident dose consequences could result. Table 8-2 summarizes the dose consequences from such an accident and provides consequences guidelines for comparison. This accident sequence is deemed extremely unlikely because the frequency of an operator error leading to a connection failure (the clearly dominant failure mode) is about $10^{-2}$ per operation. Combining this frequency with the frequency of a gaseous release event (calculated above to be about $10^{-4} / \mathrm{yr}$ ) gives an estimated annual frequency of $10^{-6} / \mathrm{yr}$. 
Table 8-1. Dose Calculation Summary for a Multi-Canister Overpack Gaseous Release Accident inside an Overpack Storage Tube Without Subsequent

Flammable Gas Explosion:

\begin{tabular}{|l|c|c|c|c|}
\hline \multicolumn{1}{|c|}{$\begin{array}{c}\text { Receptor location } \\
\text { (distance, direction) }\end{array}$} & $\begin{array}{c}\text { Duration } \\
\text { (hours) }\end{array}$ & $\begin{array}{c}\text { Unmitigated dose } \\
\text { rem (Sv) }\end{array}$ & $\begin{array}{c}\text { Evaluation guideline/ } \\
\text { release limits } \\
\text { rem (Sv) } \\
\text { unlikely }\end{array}$ & $\begin{array}{c}\text { Safety-significant } \\
\text { mitigated dose } \\
\text { rem (Sv) }\end{array}$ \\
\hline $\begin{array}{l}\text { Onsite } \\
(100 \mathrm{~m} \mathrm{E})\end{array}$ & $<1$ & $\begin{array}{c}70 \\
(7.0 \mathrm{E}-01)\end{array}$ & $\begin{array}{c}10.0 \\
(1.0 \mathrm{E}-01)\end{array}$ & $\begin{array}{c}0.07 \\
(7.0 \mathrm{E}-3)^{\mathrm{d}}\end{array}$ \\
\hline $\begin{array}{l}\text { Highway } 240 \\
(10,510 \mathrm{~m} \mathrm{~W})\end{array}$ & $<1$ & $\begin{array}{c}4.2 \mathrm{E}-02 \\
(4.2 \mathrm{E}-04)\end{array}$ & -- & - \\
\hline $\begin{array}{l}\text { Hanford Site boundary } \\
(17,390 \mathrm{~m} \mathrm{E})\end{array}$ & $<1$ & $\begin{array}{c}2.7 \mathrm{E}-02 \\
(2.7 \mathrm{E}-04)\end{array}$ & $\begin{array}{c}5.0 \\
(5.0 \mathrm{E}-02)\end{array}$ & Not calculated \\
\hline
\end{tabular}

${ }^{2}$ Fifly-year committed effective dose equivalent.

bvaluation guideline for onsite $(100 \mathrm{~m})$ receptor only.

"Unlikely event frequency is $10^{-2}$ to $10^{-4}$ per year.

${ }^{\mathrm{d}}$ Initial accident prevented, but potential dose from release of particulate through tube vent and purge cart filters is calculated.

'Because the unmitigated accident does not exceed release limits, no mitigated consequences were calculated.

Table 8-2. Dose Calculation Summary for Gaseous Release Accident from a Contaminated Overpack Storage Tube Following a Multi-Canister Overpack Pressurized Release.

\begin{tabular}{|l|c|c|c|c|}
\hline $\begin{array}{c}\text { Receptor location } \\
\text { (distance, direction) }\end{array}$ & $\begin{array}{c}\text { Duration } \\
\text { (hours) }\end{array}$ & $\begin{array}{c}\text { Unmitigated dose } \\
\text { rem (Sv) }\end{array}$ & $\begin{array}{c}\text { Evaluation guideline } \\
\text { release limits } \\
\text { rem (Sv) } \\
\text { extremely unlikely }\end{array}$ & $\begin{array}{c}\text { Safety-significant } \\
\text { mitigated dose } \\
\text { rem (Sv) }\end{array}$ \\
\hline $\begin{array}{l}\text { Onsite } \\
(100 \mathrm{~m} \mathrm{E})\end{array}$ & $<1$ & $\begin{array}{c}420 \\
(4.2)\end{array}$ & $\begin{array}{c}25.0 \\
(2.5 \mathrm{E}-01)\end{array}$ & $\begin{array}{c}0.6 \\
(6.0 \mathrm{E}-3)\end{array}$ \\
\hline $\begin{array}{l}\text { Highway 240 } \\
(10,510 \mathrm{~m} \mathrm{~W})\end{array}$ & $<1$ & $\begin{array}{c}2.4 \mathrm{E}-01 \\
(2.4 \mathrm{E}-03)\end{array}$ & - & - \\
\hline $\begin{array}{l}\text { Hanford Site boundary } \\
(17,390 \mathrm{~m} \mathrm{E})\end{array}$ & $<1$ & $\begin{array}{c}1.6 \mathrm{E}-01 \\
(1.6 \mathrm{E}-03)\end{array}$ & $\begin{array}{c}5.0 \\
(5.0 \mathrm{E}-02)\end{array}$ & Not calculated $^{\mathrm{d}}$ \\
\hline
\end{tabular}

"Fifty-year committed effective dose equivalent.

bEvaluation guideline for onsite $(100 \mathrm{~m})$ receptor only.

Extremely unlikely event frequency is $10^{-4}$ to $10^{-6}$ per year.

'Because the unmitigated accident does not exceed release limits, no mitigated consequences were calculated. 
The flammable gas explosions can simply be prevented if the overpack storage tubes are maintained free of oxygen. The fuel in the MCO produces hydrogen and oxygen gas, but nearly all the oxygen is expected to react with the fuel and remove it from the gas (HNF-SD-SNF-TI-040). If the tube environment is maintained free of air by maintaining helium in the tube, the hydrogen cannot form a flammable gas in the $\mathrm{MCO}$ or in the overpack storage tube. The overpack storage tube and tube plug are designed to provide a sealed environment that will not permit significant air ingress. The tube plug provides a port that can be used to periodically pressure-purge the overpack storage tube with inert helium gas. Immediately after an MCO is placed into the overpack storage tube, the tube can be pressure purged until essentially no oxygen remains within the tube. Without a flammable atmosphere inside the MCO or overpack storage tube, there can be no flammable gas explosion or resulting radiological release. The mitigated onsite dose from the flammable gas explosion accident is therefore reduced to $0 \mathrm{rem}$. The dose consequences from the flammable gas explosion within an overpack storage tube and the applicable guidelines are summarized for comparison in Table 8-3.

Table 8-3. Dose Calculation Summary for Flammable Gas Explosion Accident with a Multi-Canister Overpack inside an Overpack Storage Tube.

\begin{tabular}{|l|c|c|c|c|}
\hline $\begin{array}{c}\text { Receptor location } \\
\text { (distance, direction) }\end{array}$ & $\begin{array}{c}\text { Duration } \\
\text { (hours) }\end{array}$ & $\begin{array}{c}\text { Unmitigated dose* } \\
\text { rem (Sv) }\end{array}$ & $\begin{array}{c}\text { Evaluation guideline\% } \\
\text { release limits } \\
\text { rem (Sv) } \\
\text { unlikely }\end{array}$ & $\begin{array}{c}\text { Safety-significant } \\
\text { mitigated dose } \\
\text { rem (Sv) }\end{array}$ \\
\hline $\begin{array}{l}\text { Onsite } \\
(100 \mathrm{~m} \mathrm{E})\end{array}$ & $<1$ & $\begin{array}{c}81 \\
(0.81)\end{array}$ & $\begin{array}{c}10.0 \\
(1.0 \mathrm{E}-01)\end{array}$ & Accident prevented \\
\hline $\begin{array}{l}\text { Highway } 240 \\
(10,510 \mathrm{~m} \text { W) }\end{array}$ & $<1$ & $\begin{array}{c}4.8 \mathrm{E}-02 \\
(4.8 \mathrm{E}-04)\end{array}$ & -- & - \\
\hline $\begin{array}{l}\text { Hanford Site boundary } \\
(17,390 \mathrm{~m} \mathrm{E})\end{array}$ & $<1$ & $\begin{array}{c}3.1 \mathrm{E}-02 \\
(3.1 \mathrm{E}-04)\end{array}$ & $\begin{array}{c}5.0 \\
(5.0 \mathrm{E}-02)\end{array}$ & Not calculated \\
\hline
\end{tabular}

"Fifty-year committed effective dose equivalent.

Evaluation guideline for onsite $(100 \mathrm{~m})$ receptor only.

"Unlikely event frequency is $10^{-2}$ to $10^{-4}$ per year.

Because the unmitigated accident does not exceed release limits, no mitigated consequences were calculated.

\subsection{SUMMARY OF SAFETY-CLASS STRUCTURES, SYSTEMS, AND COMPONENTS AND TECHNICAL SAFETY REQUIREMENT CONTROLS}

The safety equipment designated to prevent gas release events from and flammable gas explosion in the overpack storage tubes are as follows.

- Overpack storage tubes (safety class) - Provide structural support and protection of MCOs to allow for proper passive cooling and criticality geometry control while 
maintaining gaseous confinement and enabling an inert gas atmosphere to be maintained.

- Overpack storage tube base assemblies (safety class) - Provide structural support of overpack storage tubes.

- Overpack storage tube plugs (safety significant) - Maintain gaseous confinement of the overpack storage tubes up to $2.1 \mathrm{~atm}$ pressure; contain pressure gauge to allow tube pressure to be monitored; have port that allows the overpack storage tube to be inerted, by pressure purge, with helium gas; have associated lockdown device to help maintain confinement and inert atmosphere.

- $\quad$ Cask servicing system connecting valve, connecting hose, associated piping, and the HEPA filter (safety significant) - Maintain gaseous and particulate confinement during cask venting operations.

- Bottom impact absorber (safety class) - Reduce acceleration and associated force on MCO that is dropped into tube so that unacceptable damage should not occur to $\mathrm{MCO}$.

Overpack plug cover (safety significant) - Protect overpack storage tube plug from damage from dropped or moving objects that could breach the gaseous confinement of the tube.

- Tube vent and purge cart connecting hose, interface piping, overpack storage tube plug quick-disconnect valve, and HEPA filter (safety significant) - Maintain gaseous confinement of radioactive particulate during purging operations.

\subsubsection{Safety-Class Carbon Steel Base Slab Embeds}

The carbon steel embeds for vault 1 are evaluated for the design basis earthquake based on the seismic loading from the storage tubes and the MCOs, which contain spent nuclear fuel and weigh up to $9,300 \mathrm{~kg}(20,500 \mathrm{lb})$. The embed-tube interface design accommodates the current design basis earthquake for tubes loaded with MCOs. The embeds and tube base assemblies work in concert to restrain the storage tube at the basemat elevation. Seismic analysis and the design of the embeds were performed to ACI-349, Code Requirements for Nuclear Safety Related Concrete Structures, standards and included the seismic interaction loads from two MCOs. Any future use of the embeds in vaults 2 and 3 must be evaluated against their original design, which was for seismic loading associated with the CSB mission.

There are no technical safety requirements applicable for the embed. 


\subsubsection{Overpack Storage Tube, Bellows Assembly, Tube Plugs, and Tube Base Assemblies}

The overpack storage tube and tube plugs form a confinement barrier for the spent nuclear fuel contained in off-normal MCOs. The overpack storage tube and tube plug have four safety functions:

- Maintain the geometric configuration relied on for cooling and criticality geometry control

- Maintain an inert atmosphere to preclude combustion of hydrogen in the overpack storage tube

Provide radiation shielding for operating area personnel

Confine any particulate radionuclides released from off-normal MCOs during storage conditions.

The overpack storage tube also provides the confinement boundary between the vault and the MCO. The bellows isolate the operating area atmosphere from the vault's natural convection cooling and allow for the thermal expansion of the overpack storage tube. A 44-mm (1.7- in.) clearance between the lower bellows flange and the lower embed step helps to maintain overpack storage tube integrity during a potential MCO drop accident. The tube plug seals against the tube to prevent the egress of the overpack storage tube's inert atmosphere and the ingress of oxygen, as well as to contain potentially contaminated particulate releases from the MCO exterior surface. The tube plug also provides shielding for the operators. The bottom impact absorbers mitigate the effects of an MCO drop, to keep the drop from breaching the MCO wall and/or the overpack storage tube, thus preventing the release of radionuclides into the vault atmosphere. The overpack storage tube wall provides the heat transfer surface for cooling by natural convection. The overpack storage tubes and the tube base assemblies provide structural support for the MCOs during design basis accidents, and a geometric array for cooling and criticality prevention. Tube base assemblies are provided with cooling passages to ensure that the overpack storage tube does not overheat the concrete floor of the vault basemat.

Technical safety requirements have been developed that require the following.

- All overpack storage tube plugs are in place when any MCOs are stored in the vault.

The accidents identified in the CSB hazard analysis (HNF-SD-SNF-HIE-001) that can lead to the gaseous release events in the overpack storage tubes are listed in Table 8-4 along with corresponding checklist designators; safety functions; and safety structures, systems, and components. 
Table 8-4. Safety Function and Classification of Structures, Systems, and Components Involved in Recovery Actions Related to Gaseous Releases and Explosions from Overpack Storage Tubes. (2 sheets)

\begin{tabular}{|c|c|c|c|}
\hline $\begin{array}{l}\text { Checklist } \\
\text { designator }\end{array}$ & Accident & Safety feature SSCs and TSRs & NRC ITS Class \\
\hline $\begin{array}{l}\text { OU-R-01 } \\
\text { VL-J-06 } \\
\text { OU-R-07 } \\
\text { OU-R-09 } \\
\text { OU-R-10 }\end{array}$ & $\begin{array}{l}\text { Extemal or natural } \\
\text { events cause air to } \\
\text { be introduced into } \\
\text { the overpack storage } \\
\text { tube }\end{array}$ & $\begin{array}{l}\text { General safety function is prevent collapse of Canister Storage Building structures or loss of } \\
\text { structural integrity of the facility when there is SNF in the facility } \\
\text { Safety-class SSCS: } \\
\text { - Standard and overpack storage tubes, operating deck, and vault-Provide structural integrity for } \\
\text { all design basis natural phenomena hazard criteria when SNF is in the facility } \\
\text { Safety-significant SSCs: } \\
\text { - Operating building and support buildinge-Provide structural integrity for all design basis } \\
\text { natural phenomena hazard criteria when SNF is in the facility } \\
\text { No TSRs for recovery-related controls }\end{array}$ & $\begin{array}{l}\text { ITS Category A: } \\
\text { Seismically } \\
\text { qualified storage } \\
\text { tubes, operating } \\
\text { deck, and vault } \\
\text { ITS Category B: } \\
\text { Seismically } \\
\text { qualified, tornado- } \\
\text { hardened building }\end{array}$ \\
\hline $\begin{array}{l}\text { OA-N-O1b } \\
\text { OA-N-03b } \\
\text { OA-N-04 }\end{array}$ & $\begin{array}{l}\text { Radiological } \\
\text { exposure to workers }\end{array}$ & $\begin{array}{l}\text { General safety function is provide shielding, consistent with ALARA principles for personnel in the } \\
\text { operating area } \\
\text { Safety-significant SSCs: } \\
\text { - Overpack storage tube assemblies (tube plug)-Provide radiation protection to the operating } \\
\text { area from MCOs in the overpack storage tube when there are MCOs in the storage tubes } \\
\text { ISRs: }\end{array}$ & $\begin{array}{l}\text { ITS classification is } \\
\text { not applicable } \\
\text { ( }<5 \text { rem })\end{array}$ \\
\hline $\begin{array}{l}\text { OA-B-07 } \\
\text { OA-B-10 } \\
\text { OA-H-06c } \\
\text { OA-N-01b } \\
\text { OA-N-03b } \\
\text { OU-R-01 }\end{array}$ & $\begin{array}{l}\text { Loss of confinement } \\
\text { by the overpack } \\
\text { storage tube }\end{array}$ & $\begin{array}{l}\text { General safety function is to contain radiological particulate } \\
\text { Safety-significant SSCs: } \\
\text { Overpack storage tube assemblies (storage tubes, tube plug, bellows, seal, lockdown, pressure } \\
\text { gauge)-Contain radiological particulate for pressure up to } 75 \mathrm{lb} / \mathrm{in}^{2} \text { gauge when MCO is in an } \\
\text { overpack storage tube } \\
\text { No TSRs for recovery-related controls }\end{array}$ & $\begin{array}{l}\text { ITS classification is } \\
\text { not applicable } \\
(<5 \text { rem })\end{array}$ \\
\hline
\end{tabular}


Table 8-4. Safety Function and Classification of Structures, Systems, and Components Involved in Recovery Actions Related to Gaseous Releases and Explosions from Overpack Storage Tubes. (2 sheets)

\begin{tabular}{|c|c|c|c|}
\hline $\begin{array}{l}\text { Checklist } \\
\text { designator }\end{array}$ & Accident & Safety feature SSCs and TSRs & NRC ITS Class \\
\hline OA-J-06d & $\begin{array}{l}\text { Loss of inert gas } \\
\text { atmosphere in the } \\
\text { overpack storage } \\
\text { tube }\end{array}$ & $\begin{array}{l}\text { General safety function is to prevent hydrogen detonation or deflagration from the off-normal MCO; } \\
\text { preclude loss of inert gas and maintain inert gas atmosphere in overpack storage tube } \\
\text { Safetv-significant SSCs: } \\
\text { - Overpack storage tube assemblies (storage tubes, tube plug, seal, lockdown device, tube } \\
\text { cover)-Preclude loss of inert gas and maintain inert gas atmosphere (to prevent oxygen ingress) } \\
\text { in an overpack storage tube when there is an MCO in the overpack } \\
\text { No TSRs for recovery-related controls }\end{array}$ & $\begin{array}{l}\text { ITS Category B: } \\
\text { Overpack storage tube } \\
\text { assemblies (storage } \\
\text { tubes, tube plug, seals, } \\
\text { lockdown device, tube } \\
\text { cover) }\end{array}$ \\
\hline $\begin{array}{l}\text { OA-G-14 } \\
\text { OA-F-02 }\end{array}$ & $\begin{array}{l}\text { Damage to overpack } \\
\text { storage tube plug } \\
\text { assembly by falling, } \\
\text { dropped, or } \\
\text { colliding objects }\end{array}$ & $\begin{array}{l}\text { General safety function is to prevent falling, dropped, or moving objects from impacting overpack } \\
\text { storage tube plug assembly } \\
\text { Safety-significant SSCs: } \\
\text { Overpack storage tube cover-Prevents objects from falling onto the tube plug and causing loss } \\
\text { of gaseous confinement or inert gas atmosphere when there is an MCO in the overpack storage } \\
\text { tube } \\
\text { No TSRs for recovery-related controls }\end{array}$ & $\begin{array}{l}\text { ITS classification is } \\
\text { not applicable } \\
\text { ( }<5 \text { rem) }\end{array}$ \\
\hline $\begin{array}{l}\text { OA-D-0lb } \\
\text { (battery on } \\
\text { purge cart) }\end{array}$ & $\begin{array}{l}\text { Loss of MCO } \\
\text { integrity caused by } \\
\text { corrosion of the } \\
\text { MCO wall or loss of } \\
\text { seals on the } \\
\text { overpack storage } \\
\text { tube plug }\end{array}$ & $\begin{array}{l}\text { General safety function is to prevent a gas release from overpack storage tube into the operating } \\
\text { area from corrosion by battery acid } \\
\text { Safety-significant SSCs: } \\
\text { - Isolated battery compartment-Contains cart battery acid to confine any acid leakage from the } \\
\text { battery to the purge cart when the cart is in the operating area } \\
\text { No TSRs for recovery-related controls }\end{array}$ & $\begin{array}{l}\text { ITS Category B: } \\
\text { Isolated compartment }\end{array}$ \\
\hline
\end{tabular}

'Building is safety significant consistent with waiver 1 to HNF-PRO-704, Hazard and Accident Analysis Process, Fluor Daniel Hanford, Incorporated, Richland, Washington.

${ }^{b} T$ The corrosion is caused by a chemical reaction with the battery acid spilled from the purge cart battery.

$\mathrm{ALARA}=$ as low as reasonably achievable.

ITS $=$ important to safety.

$\mathrm{MCO}=$ multi-canister overpack

$\mathrm{NRC}=$ U.S. Nuclear Regulatory Commission.

SSC $=$ structure, system, and component

$\mathrm{SNF}=$ spent nuclear fuel.

$\mathrm{TSR}=$ technical safety requirement. 


\subsection{REFERENCES}

ACI-349, 1985, Code Requirements for Nuclear Safety Related Concrete Structures, American Concrete Institute, Farmington Hills, Michigan.

CSB-RM-0011, 1997, ASME VIII Evaluation of Storage Tubes, Fluor Daniel, Incorporated, Richland, Washington.

DOE-HDBK-3010-94, 1994, Airborne Release Fractions/Rates and Respirable Fractions/Rates for Nonreactor Nuclear Facilities, U.S. Department of Energy, Washington, D.C.

Hinds, W.C., 1982, Aerosol Technology: Properties, Behavior, and Measurements of Airborne Particles, John Wiley \& Sons, New York, New York.

HNF-2256, 1998, Simulation of Normal and Off-Normal Multi-Canister Overpack Behavior, Rev. 1, Fluor Daniel Hanford, Incorporated, Richland, Washington.

HNF-SD-SNF-HIE-001, 1998, Canister Storage Building Hazard Analysis Report, Rev. 1, Fluor Daniel Hanford, Incorporated, Richland, Washington.

HNF-SD-SNF-TI-015, 1998, Spent Nuclear Fuel Project Technical Databook, Rev. 5, Fluor Daniel Hanford, Incorporated, Richland, Washington.

HNF-SD-SNF-TI-040, 1998, MCO Internal Gas Composition and Pressure During Interim Storage, Rev. 1, Fluor Daniel Hanford, Incorporated, Richland, Washington.

HNF-SD-SNF-TI-059, 1998, A Discussion on the Methodology for Calculating Radiological and Toxicological Consequences for the Spent Nuclear Fuel Project at the Hanford Site, Rev. 1, Fluór Daniel Hanford, Incorporated, Richland, Washington.

Sellers, E. D., 1997, Risk Evaluation Guidelines (REGs) to Ensure Inherently Safer Designs (Letter 97-SFD-172 to H. J. Hatch, President, Fluor Daniel Hanford, Incorporated, August 26), U.S. Department of Energy, Richland Operations Office, Richland, Washington.

SFPE, 1992, SFPE Handbook of Fire Protection Engineering, Society of Fire Protection Engineers, Boston, Massachusetts.

Whitwell, J. C., and R. K. Toner, 1969, Conservation of Mass and Energy, Blaisdell Publishing Company, Waltham, Massachusetts. 
SNF-3328 REV 0

APPENDIX A

\section{EVENT TREE ANALYSIS FOR DESIGN BASIS ACCIDENTS}


SNF-3328 REV 0

This page intentionally left blank. 


\section{CONTENTS}

A1.0 EVENT TREE FOR GASEOUS RELEASE IN THE CANISTER STORAGE BUILDING AT THE SAMPLING/WELD STATION

A2.0 EVENT TREE FOR HYDROGEN EXPLOSIONS INSIDE A MULTICANISTER OVERPACK AT THE CANISTER STORAGE BUILDING

A3.0 EVENT TREES FOR HYDROGEN EXPLOSIONS EXTERNAL TO THE MULTI-CANISTER OVERPACK AT THE CANISTER STORAGE BUILDING . . A-10 A3.1 EVENT TREE FOR HYDROGEN EXPLOSION DURING CASK VENTING

A3.2 EVENT TREE FOR A HYDROGEN EXPLOSION DURING MULTI-CANISTER OVERPACK HANDLING

A3.3 EVENT TREE FOR A HYDROGEN EXPLOSION DURING MULTI-CANISTER OVERPACK STORAGE

A3.4 EVENT TREE FOR A HYDROGEN EXPLOSION DURING

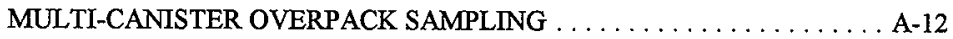

A3.5 REFERENCES

\section{LIST OF FIGURES}

A1-1 Event Tree Used to Develop Multi-Canister Overpack Gas Release Probability at the Canister Storage Building Sampling/Weld Station

A2-1 Event Tree Showing Consequences of a Hydrogen Explosion During Helium Recharge at the Sampling/Weld Station

A3-1 Event Tree Showing Consequences of a Hydrogen Explosion During Cask

Venting

A3-2 Event Tree Showing Consequences of a Hydrogen Explosion During Multi-Canister Overpack Handling ...

A3-3 Event Tree Showing Consequences of a Hydrogen Explosion During Multi-Canister Overpack Storage .

A3-4 Event Tree Showing Consequences of a Hydrogen Explosion During Multi-Canister Overpack Sampling . 


\section{APPENDIX A \\ EVENT TREE ANALYSIS FOR DESIGN BASIS ACCIDENTS}

\section{A1.0 EVENT TREE FOR GASEOUS RELEASE IN THE CANISTER STORAGE BUILDING AT THE SAMPLING/WELD STATION}

Figure A1-1 shows the event tree used to develop the probability of a gaseous release from a multi-canister overpack (MCO) at the Canister Storage Building (CSB) sampling/weld station.

Initiating event (Event IE) : $24 \mathrm{MCO}$ will be sampled at the CSB sampling/weld station for monitoring purposes three times each in the first year for a total of $72 \mathrm{MCO}$ samples per year.

Sequence 1 Event L: The probability that the sample line will maintain leak integrity (no leaks) involves the MCO valve operator attachment to the MCO maintaining leak. integrity, the flexible line inside the sample hood maintaining leak integrity, and the flexible line outside of the sample hood through the sample cart maintaining leak integrity.

The probability that the MCO valve operator attachment to the MCO will maintain leak integrity is estimated as 0.99 . The value of 0.01 is the estimated operator error of 1 in a hundred that the operator will not tighten the bolts on the valve operator attachment such that a leak can occur between the attachment and the $\mathrm{MCO}$.

The probability that a flexible line inside the sample hood will maintain leak integrity is $0.999984(1-[4 \mathrm{E}-06 / \mathrm{h} * 4 \mathrm{~h}])$. The value of $4 \mathrm{E}-06 / \mathrm{h}$ is a value for lightly stressed hose based on DP-1633, Component Failure-Rate Data with Potential Applicability to a Nuclear Fuel Reprocessing Plant (page 18). The failure rate for lightly stressed hose was used as surrogate for the failure rate for flexible hose in the sampling/weld station because no failure data was readily available for flexible hose. Also, the failure rate for lightly stressed hose is more conservative than for piping leaks. Failure rates for piping seem inappropriate for flexible hose because the flexibility of the hose also makes it more likely to fail than piping. The four hours used in the above calculation represents an estimated amount of time that the flexible hose will be used for sampling for each MCO sampling occurrence.

The probability that a flexible line outside the sample hood, from the hood through the sample cart, will maintain leak integrity is $0.999984(1-[4 \mathrm{E}-06 / \mathrm{h} * 4 \mathrm{~h}])$. The value of $4 \mathrm{E}-06 / \mathrm{h}$ is a value for lightly stressed hose based on DP-1633 (page 18). The failure rate for lightly stressed hose was used as surrogate for the failure rate for flexible hose in the sampling/weld station because no failure data was readily available for flexible hose. Also, the failure rate for lightly stressed hose is more 
conservative than for piping leaks. Failure rates for piping seem inappropriate for flexible hose because the flexibility of the hose also makes it more likely to fail than piping. The four hours used in the above calculation represents an estimated amount of time that the flexible hose will be used for sampling for each MCO sampling occurrence.

If the sample line leak integrity is maintained from MCO port 2 through the sample cart, no gaseous release will occur from the sampling/weld station, thus no release consequence. The likelihood of no releases occurring is the multiplication of the probabilities maintaining leak integrity calculated above $(0.99 * 0.999984$ $* 0.999984=0.989968$ or approximately 0.99$)$ times the number of MCOs sampled per year $(0.989968 / \mathrm{MCO}$ sampled * $72 \mathrm{MCOs}$ sampled/year $=$ approximately 71 /year. Another way to reach the same result is sum the failure probabilities and subtract them from $1(1-[0.01+0.000016+0.000016]=$ 0.989968 or approximately 0.99 ) times the number of MCOs sampled per year

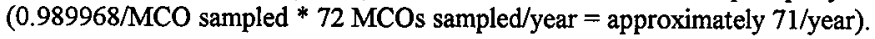

Sequence 2 Event L: The probability that the sample line will leak involves a leak of the MCO valve operator attachment to the $\mathrm{MCO}$, a leak of the flexible line inside the sample hood, and a leak of the flexible line outside of the sample hood through the sample cart.

The probability that the MCO valve operator attachment to the MCO will leak is estimated as 0.01 . The value of 0.01 is the estimated operator error of 1 in a hundred that the operator will not tighten the bolts on the valve operator attachment such that a leak can occur between the attachment and the MCO.

The probability that a flexible line inside the sample hood will leak is 0.000016 $(4 \mathrm{E}-06 / \mathrm{h} * 4 \mathrm{~h})$. The value of $4 \mathrm{E}-06 / \mathrm{h}$ is a value for lightly stressed hose based on DP-1633 (page 18). The failure rate for lightly stressed hose was used as surrogate for the failure rate for flexible hose in the sampling/weld station because no failure data was readily available for flexible hose. Also, the failure rate for lightly stressed hose is more conservative than for piping leaks. Failure rates for piping seem inappropriate for flexible hose because the flexibility of the hose also makes it more likely to fail than piping. The four hours used in the above calculation represents an estimated amount of time that the flexible hose will be used for sampling for each MCO sampling occurrence.

The probability that a flexible line outside the sample hood, from the hood through the sample cart, will leak is $0.000016(4 \mathrm{E}-06 / \mathrm{h} * 4 \mathrm{~h})$. The value of $4 \mathrm{E}-06 / \mathrm{h}$ is a value for lightly stressed hose based on DP-1633 (page 18). The failure rate for lightly stressed hose was used as surrogate for the failure rate for flexible hose in the sampling/weld station because no failure data was readily available for flexible hose. Also, the failure rate for lightly stressed hose is more conservative than for piping leaks. Failure rates for piping seem inappropriate for flexible hose because the flexibility of the hose also makes it more likely to fail than piping. The four 
hours used in the above calculation represents an estimated amount of time that the flexible hose will be used for sampling for each MCO sampling occurrence.

If the sample line leaks and no high-efficiency particulate air filtration is credited, an unfiltered gaseous release will occur from the sampling/weld station. The likelihood of a release occurring is the sum of the probabilities leaks calculated above $(0.01+0.000016+0.000016=0.010032$ or approximately 0.01$)$ times the number of MCOs sampled per year $(0.010032 / \mathrm{MCO}$ sampled * $72 \mathrm{MCOs}$ sampled/year $=$ approximately $0.7 /$ year.

\section{REFERENCE}

DP-1633, 1982, Component Failure-Rate Data with Potential Applicability to a Nuclear Fuel Reprocessing Plant, E. I. du Pont de Nemours \& Co., Savannah River Laboratory, Aiken, South Carolina. 
Figure A1-1. Event Tree Used to Develop Multi-Canister Overpack Gas Release Probability at the Canister Storage Building Sampling/Weld Station.

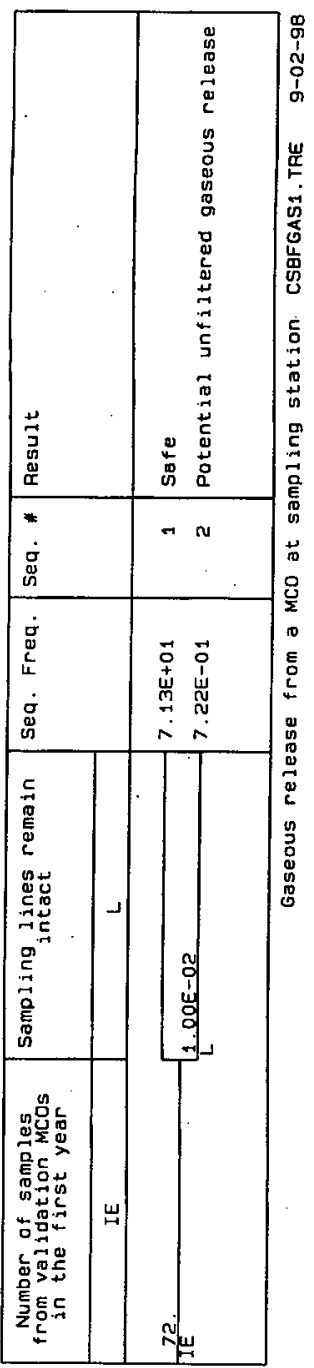




\section{A2.0 EVENT TREE FOR HYDROGEN EXPLOSIONS INSIDE A MULTI-CANISTER OVERPACK AT THE CANISTER STORAGE BUILDING}

The event tree maps the sequence of events that could lead to a hydrogen explosion inside the MCO. The event tree for a hydrogen explosion during cask venting is shown in Figure A2-1.

The first event on the tree is labeled "MCO SAMPLING." This item accounts for the fact that the events leading up to a hydrogen explosion start with the operation that samples the cask. It also shows the activity will occur three times for each of the 24 monitoring MCOs received at the CSB, or a total of 72 times per year.

The second event is labeled "NORMAL SAMPLE." This item evaluates the effect of inadvertently depressurizing the $\mathrm{MCO}$ rather than only removing enough gas for the sample. The probability of this occurring is taken to be 0.01 per MCO, as shown in Figure A2-1.

The third event is labeled "HE RECHARGE." This item evaluates the inadvertent presence of oxygen in the helium system. This could happen two ways. The first way assumes the helium lines are depressurized for maintenance, filled with air, and not purged prior to use. The estimated probability for this failure is 0.01 per year due to operator error. The second way assumes the helium supplier fills the helium supply tanks or supply truck with oxygen. Because multiple errors on the suppliers part are necessary for it to occur, it is assigned a probability of 0.0001 per year as shown on Figure A2-1.

The overall probability for the explosion inside the $\mathrm{MCO}$ depends on which failure occurs at the third step. If air is present in the helium lines, the overall probability is $7.2 \times 10^{-3}$ per year. If oxygen is present in the helium supply, the overall probability is $7.2 \times 10^{-5}$ per year. This accident may therefore be in either the "unlikely" or "extremely unlikely" category. 


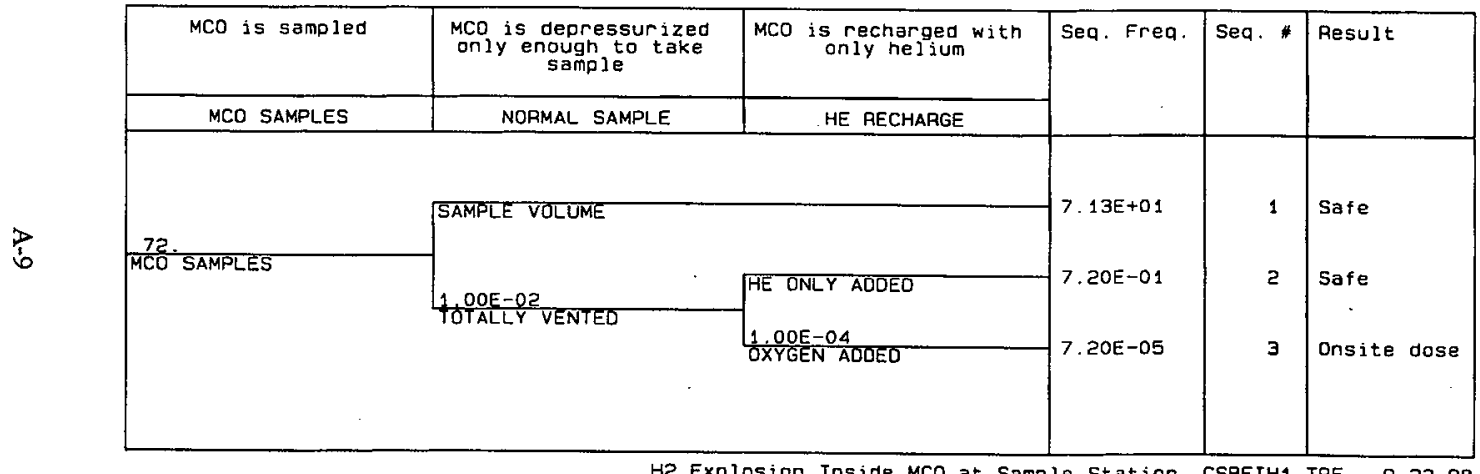




\section{A3.0 EVENT TREES FOR HYDROGEN EXPLOSIONS EXTERNAL TO THE MULTI-CANISTER OVERPACK AT THE CANISTER STORAGE BUILDING}

The Figure A3-1 event tree maps the sequence of events that could lead to a hydrogen explosion outside the multi-canister overpack. The event tree includes both initiators and mitigation. The diagrams for the hydrogen explosions discussed earlier are presented in this appendix.

\section{A3.1 EVENT TREE FOR HYDROGEN EXPLOSION DURING CASK VENTING}

The event tree for a hydrogen explosion during cask venting is shown in Figure A3-1. The first event on the tree is labeled "CASK VENT." This item accounts for the fact that the events leading up to a hydrogen explosion start with the operation that vents the cask. It also shows the activity will occur at least once for each multi-canister overpack received at CSB.

The second event is labeled "MCO." This item evaluates the presence of a leak from the $\mathrm{MCO}$ to the transportation cask which exceeds the leakage criteria. The upper branch indicates that the leakage is within the criteria. The lower branch indicates that the MCO leaks faster than the criteria. The calculations assume the leak rate is 10,000 times the leak rate criteria for a mechanically sealed MCO. According to DP-1633, Component Failure-Rate Data with Potential Applicability to a Nuclear Fuel Reprocessing Plant, the failure rate for O-ring seals leaking is $1 \times 10^{-6}$ per hour. Multiplying this by the number of hours in a year gives about 0.01 per year per MCO. An additional failure to detect the leak must occur at the Cold Vacuum Drying Facility. Thus, the overall failure probability is $1 \times 10^{-4}$ per year per MCO, as shown in Figure A3-1.

The third event is labeled "DEPRESSURIZE." This item evaluates the effect of venting duration. The upper branch indicates that the flow from the cask is normally throttled to reduce the hydrogen concentration in the exhauster. The lower branch indicates that the cask pressure is relieved suddenly so that there is an explosive concentration hydrogen and air in the exhauster. A probability of 0.01 is assigned to this failure since it is personnel related.

The fourth event is labeled "IGNITION." This item accounts for the location of the ignition source in the portable exhauster. The upper branch indicates the explosion occurs in the ductwork, leading to possible injury of personnel nearby. The lower branch indicates the explosion occurs in the high-efficiency particulate air filter, releases radioactivity to the environment. The overall probability of an explosion is $1 \times 10^{-4}$ per year. This places the accident in the "unlikely" category. 


\section{A3.2 EVENT TREE FOR A HYDROGEN EXPLOSION DURING MULTI-CANISTER OVERPACK HANDLING}

The event tree for a hydrogen explosion during cask venting is shown in Figure A3-2. The first event on the tree is labeled "MCO MOVEMENT." This item accounts for the fact that the events leading up to a hydrogen explosion start with relocating an $\mathrm{MCO}$ using the $\mathrm{MCO}$ handling machine (MHM). It also shows the activity will occur at least once for each multi-canister overpack received at CSB.

The second event is labeled "MHM." This item evaluates the effect of an accident which immobilizes the MHM and disables its ventilation system. An example is a power failure lasting two days. The upper branch indicates that no malfunction has occurred and the lower branch indicates that the 2 days without ventilation used in the calculations has occurred. From WHC-EP-0811, Analysis of Power Loss Data for the 200 Area Tank Farms in Support of $K$ Basin SAR Work, the projected frequency for a 2 day power outage is about 0.001 , as shown in Figure A3-2.

The third event is labeled "MCO." This item evaluates the presence of a leak from the MCO to the transportation cask which exceeds the leakage criteria. The upper branch indicates that the leakage is within the criteria. The lower branch indicates that the MCO leaks faster than the criteria. The calculations assume the leak rate is 10,000 times the leak rate criteria for a mechanically sealed $\mathrm{MCO}$. According to DP-1633 the failure rate for $\mathrm{O}$-ring seals leaking is $1 \times 10^{-6}$ per hour. Multiplying this by the number of hours in a year gives about 0.01 per year per $\mathrm{MCO}$, as shown in Figure A3-2.

The fourth event is labeled "IGNITION." This item accounts for the location of the ignition source in the MHM. The upper branch indicates the explosion occurs inside the MHM, leading to possible damage to the MHM. The lower branch indicates the explosion occurs in the high-efficiency particulate air filter, releases radioactivity to the environment. The overall probability of an explosion is $1 \times 10^{-3}$ per year. This places the accident in the "unlikely" category.

\section{A3.3 EVENT TREE FOR A HYDROGEN EXPLOSION DURING MULTI-CANISTER OVERPACK STORAGE}

The event tree for a hydrogen explosion during MCO storage is shown in Figure A3-3. The first event on the tree is labeled "STORAGE TUBE." This item accounts for the fact that the events leading up to this hydrogen explosion start with the placement of the MCO in a storage tube. It also shows the activity will occur at least once for each MCO scheduled for gas sampling.

The second event is labeled "MCO." This item evaluates the presence of a leak from the MCO to the transportation cask which exceeds the leakage criteria. The upper branch indicates that the leakage is within the criteria. The lower branch indicates that the MCO leaks faster than the criteria. The calculations assume the leak rate is 10,000 times the leak rate criteria for a mechanically sealed MCO. According to DP-1633 the failure rate for O-ring seals leaking is 
$1 \times 10^{-6}$ per hour. Multiplying this by the number of hours in a year gives about 0.01 per year per $\mathrm{MCO}$, as shown in Figure A3-3.

Since the storage tubes may also have MCOs which have been sealed by welding, an estimate of excessive leakage was made for these also. From EGG-SSRE-8875, Generic Component Failure Data Base for Light Water and Liquid Sodium Reactor PRAs, the probability of welded pipe failure is about $1 \times 10^{-9}$ per foot per hour. Multiplying by the approximate number of feet of weld $(20 \mathrm{ft})$ and the number of hours in a year $(8,760$ hours) gives a probability of $1 \times 10^{-4}$ per year per MCO. Since there are about 10 times more welded MCOs handled per year (200) than mechanically sealed MCOs (24), the excessive leakage probability is 10 times lower than that of the mechanically sealed MCOs.

The third event is labeled "IGNITION." This item accounts for the presence of an ignition source in the storage tube. The upper branch indicates an ignition source does not exist while the lower branch indicates an ignition source exists. The overall probability of an explosion is 0.12 per year. This places the accident in the "anticipated" category.

\section{A3.4 EVENT TREE FOR A HYDROGEN EXPLOSION DURING MULTI-CANISTER OVERPACK SAMPLING}

The event tree for a hydrogen explosion during MCO sampling is shown in Figure A3-4. The first event on the tree is labeled "SAMPLING." This item accounts for the fact that the events leading up to a hydrogen explosion start with relocating an MCO to the sample pit. It also shows the activity will occur at least once for each multi-canister overpack scheduled for sampling.

The second event is labeled "HOSE." This item evaluates the effect of a failure of the sample hose connection that leads to a release of activity from the MCO into the sample hood. The upper branch indicates that no malfunction has occurred and the lower branch indicates that the connection failure has occurred. To approximate the probability of this event, the leakage probability for check valves was used. From DP-1633 the probability for a check valve failing to close is 0.001 per operation. Additional considerations are the failure of lightly stressed hose $\left(4 \times 10^{-6}\right.$ per hour $)$ and the external leakage of a valve $\left(3 \times 10^{-8}\right.$ per hour $)$.

The third event is labeled "GAS." This item evaluates whether the leak rate from the failed connection is enough to produce a flammable mixture in the sample hood. The upper branch indicates that the hydrogen concentration is below the lower flammable limit. The lower branch indicates that the hydrogen concentration is above the lower flammable mixture.

The fourth event is labeled "IGNITION." This item accounts for the location of the ignition source in the sample hood. The upper branch indicates the explosion occurs inside the hood, leading to possible injury to personnel. The lower branch indicates the explosion occurs in the high-efficiency particulate air filter, releases radioactivity to the environment. The overall probability of an explosion is 0.02 per year. This places the accident in the "anticipated" category. 


\section{A3.5 REFERENCES}

DP-1633, 1982, Component Failure-Rate Data with Potential Applicability to a Nuclear Fuel Reprocessing Plant, E. I. du Pont de Nemours \& Co., Savannah River Laboratory, Aiken, South Carolina.

EGG-SSRE-8875, 1990, Generic Component Failure Data Base for Light Water and Liquid Sodium Reactor PRAs, EG\&G Idaho, Idaho National Engineering Laboratory, Idaho Falls, Idaho.

WHC-EP-0811, 1994, Analysis of Power Loss Data for the 200 Area Tank Farms in Support of $K$ Basin SAR Work, Westinghouse Hanford Company, Richland, Washington. 
SNF-3328 REV 0

Figure A3-1. Event Tree Showing Consequences of a Hydrogen Explosion During Cask Venting:

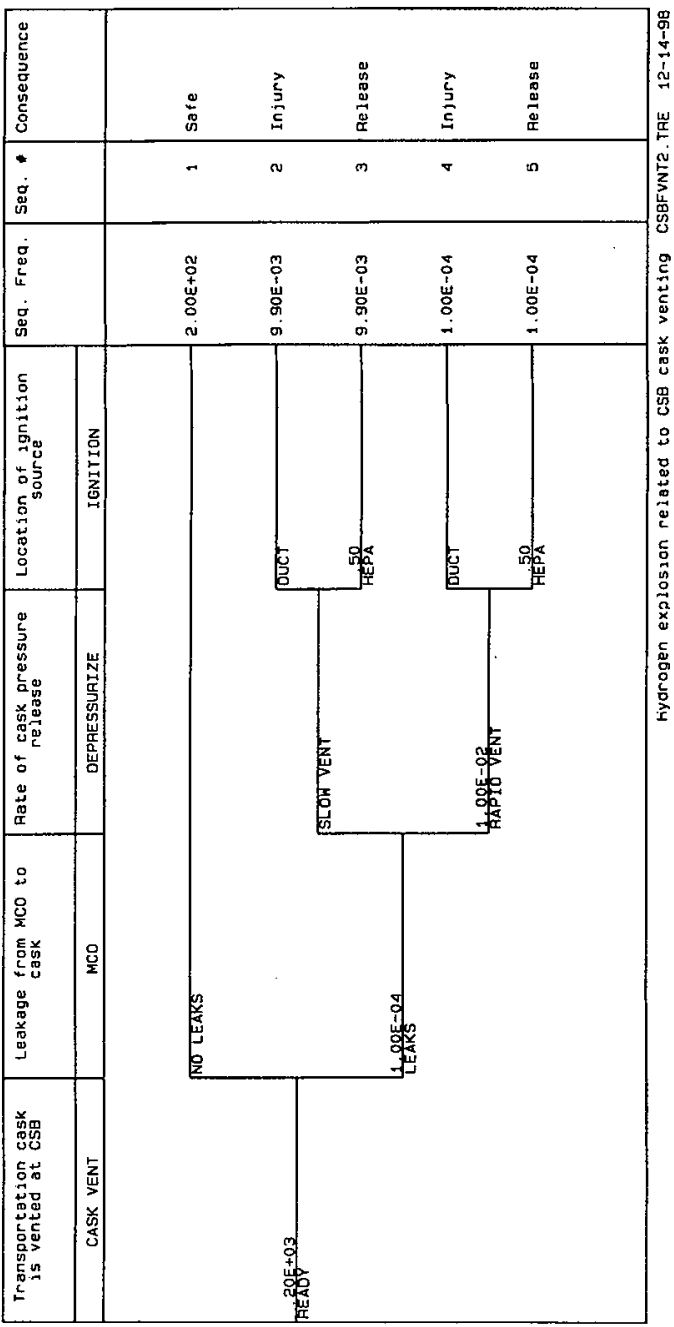


Figure A3-2. Event Tree Showing Consequences of a Hydrogen Explosion During Multi-Canister Overpack Handling.

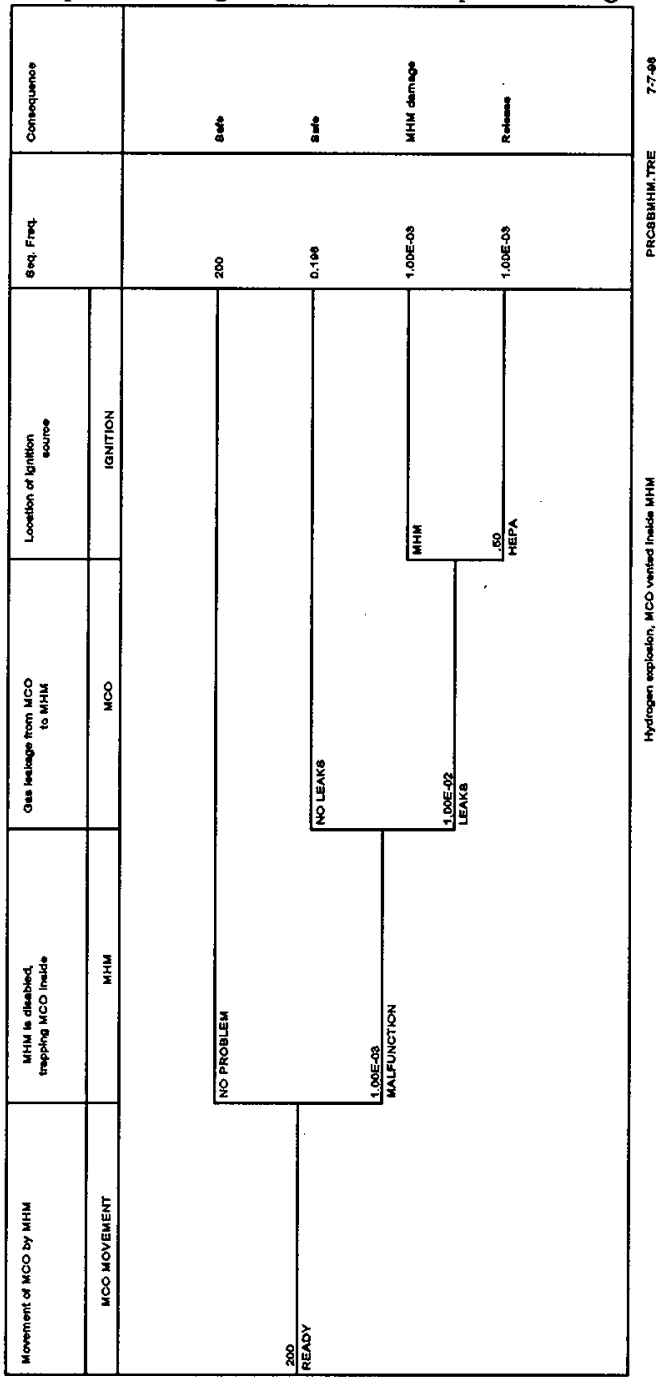


Figure A3-3. Event Tree Showing Consequences of a Hydrogen Explosion During Multi-Canister Overpack Storage.

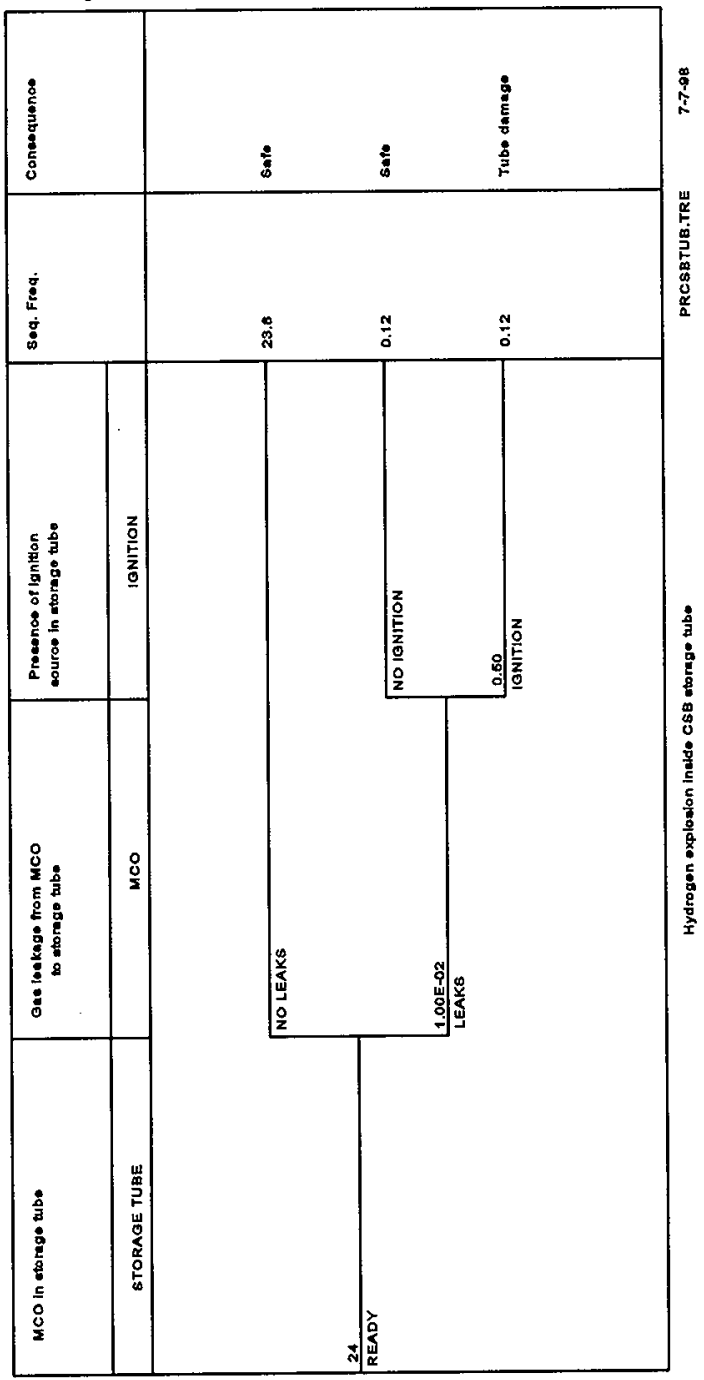


Figure A3-4. Event Tree Showing Consequences of a Hydrogen

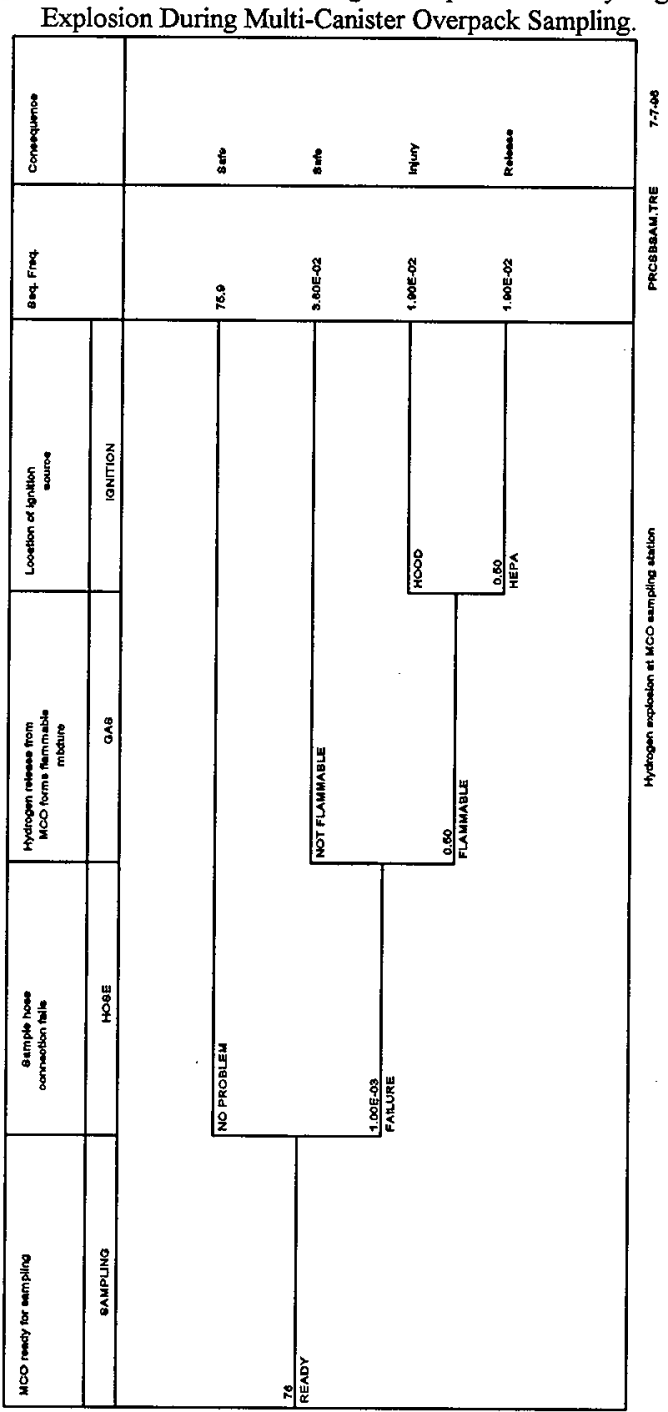


SNF-3328 REV 0

This page intentionally left blank. 
SNF-3328 REV 0

APPENDIX B

ISO-PC OUTPUT TO ESTIMATE HIGH-EFFICIENCY

PARTICULATE AIR FILTER LOADING 
SNF-3328 REV 0

This page intentionally left blank. 


\section{APPENDIX B \\ ISO-PC OUTPUT TO ESTIMATE HIGH-EFFICIENCY PARTICULATE AIR FILTER LOADING}

ISO-PC Version 1.98 (WHC-SD-WM-UM-030) computes dose rates from X-rays, gamma rays, and bremsstrahlung radiation for simple arrangements of source and shields. The user selects the geometry and supplies values for dimensions and activities of the various isotopes present in the source region.

The ISO-PC program is the result of extensive revisions to the original ISOSHLD-II program (BNWL-236). Validation was carried out for the bremsstrahlung calculations (BNWL-236-SUP1). Other portions of the calculations have been verified (WHC-SD-SQA-CSWD-303).

In the present application, the geometry was the rectangular slab with slab shields. The source is $61 \mathrm{~cm}$ tall, $61 \mathrm{~cm}$ wide, and $30 \mathrm{~cm}$ thick (24 in. tall, $24 \mathrm{in}$. wide, and $12 \mathrm{in}$. thick). The dose point is to the side, so the apparent thickness is $61 \mathrm{~cm}$ (24 in.). A thin layer (1 mm [0.04 in.]) of iron represents the filter housing. The dose point is $5.08 \mathrm{~cm}$ ( 2 in.) from the housing, which is $2.54 \mathrm{~cm}$ ( 1 in.) from the filter.

A high-efficiency particulate air (HEPA) filters are made of fiberglass and wood, and weigh about $18 \mathrm{~kg}$ ( $40 \mathrm{lb}$ ). Therefore, the HEPA filter array was modeled as a homogenized region with a density of $0.16 \mathrm{~g} / \mathrm{cm}^{3}$. HEPA filters are made of fiberglass, so the source region was modeled as Hanford sand with this density to represent the filter media.

The isotopes with significant gamma emissions were used in the source. Amounts found in the safety basis list were used (HNF-SD-SNF-TI-059). Since the amounts are for one metric ton of fuel, a source scale factor of $1.5 \times 10^{-6}$ was used in the program input to reduce the source to $1.5 \mathrm{~g}$ of fuel. Program output is listed below. Note that the input file (HEPA) is appended to the output. 
SNF-3328 REV 0

Run started at 10:28:29 02/20/98

ISO-PC Version 1.98

August 1994

originally ISOSHDD-II; RIBD was removed

Please send questions or comments to:

Paul D. Rittmann, PhD CHP 509-376-8715

Westinghouse Hanford Company H6-30

PO Box 1970 Richland, WA 99352

Title Iine from Library File (ISO-PC.LIB):

Attenuation \& Buildup for 30 Groups; Photon \& Beta Production 2/14/96 PDR

Run Title: CSB Portable HEPA Filter with $1.5 \mathrm{~g}$ SNF Fuel (Safety Source)

2" to the side

Table of Source Activity:

Scale Factor $=1.500 \mathrm{E}-06$

Isotope Initial Final

Name Values Curies

CO- $60 \quad 2.09 \mathrm{E}+00 \quad 3.135 \mathrm{E}-06$

SR- $90 \quad 6.93 \mathrm{E}+03 \quad 1.040 \mathrm{E}-02$

$Y-90 \quad 6.93 E+03 \quad 1.040 E-02$

CD-113M 2.78E+00 4.170E-06

CS-134 6.47E+00 9.705E-06

CS-137 $9.66 \mathrm{E}+03 \quad 1.449 \mathrm{E}-02$

BA-137M $9.14 \mathrm{E}+03 \quad 1.371 \mathrm{E}-02$

PM-147 1.09E+02 1.635E-04

SM-151 1.02E+02 1.530E-04

EU-154 1.13E+02 1.695E-04

EU-155 1.06E+01 1.590E-05

2" to the side

Shield Composition, g/cc

Shield 1 shield 2 shield 3 shield 4

$\begin{array}{llllll}\text { AIR } & 0.000 \mathrm{E}+00 & 1.200 \mathrm{E}-03 & 0.000 \mathrm{E}+00 & 1.290 \mathrm{E}-03 \\ \text { HAN SOIL } & 1.600 \mathrm{E}-01 & 0.000 \mathrm{E}+00 & 0.000 \mathrm{E}+00 & 0.000 \mathrm{E}+00 \\ \text { IRON } & 0.000 \mathrm{E}+00 & 0.000 \mathrm{E}+00 & 7.860 \mathrm{E}+00 & 0.000 \mathrm{E}+00\end{array}$


SNF-3328 REV 0

\begin{tabular}{|c|c|c|c|c|}
\hline Totals: & $1.600 \mathrm{E}-01$ & $1.200 \mathrm{E}-03$ & $7.860 \mathrm{E}+00$ & $1.290 \mathrm{E}-03$ \\
\hline , $\mathrm{MeV}$ & & & & \\
\hline 0.015 & $1.952 \mathrm{E}+00$ & $1.904 \mathrm{E}-03$ & $4.622 \mathrm{E}+02$ & $2.046 \mathrm{E}-03$ \\
\hline 0.025 & $4.535 E-01$ & $5.710 \mathrm{E}-04$ & $1.096 \mathrm{E}+02$ & $6.138 \mathrm{E}-04$ \\
\hline 0.035 & $1.817 \mathrm{E}-01$ & $3.408 \mathrm{E}-04$ & $4.186 \mathrm{E}+01$ & $3.664 E-04$ \\
\hline 0.045 & $9.853 \mathrm{E}-02$ & $2.639 \mathrm{E}-04$ & $2.035 E+01$ & $2.837 \mathrm{E}-04$ \\
\hline 0.055 & $6.493 \mathrm{E}-02$ & $2.317 \mathrm{E}-04$ & $1.178 \mathrm{E}+01$ & $2.491 \mathrm{E}-04$ \\
\hline 0.065 & $4.872 \mathrm{E}-02$ & $2.153 \mathrm{E}-04$ & $7.715 \mathrm{E}+00$ & $2.314 \mathrm{E}-04$ \\
\hline 0.075 & $3.981 E-02$ & $2.032 \mathrm{E}-04$ & $5.451 E+00$ & $2.184 E-04$ \\
\hline 0.085 & $3.442 \mathrm{E}-02$ & $1.944 \mathrm{E}-04$ & $4.096 \mathrm{E}+00$ & $2.090 \mathrm{E}-04$ \\
\hline 0.095 & $3.091 \mathrm{E}-02$ & $1.878 \mathrm{E}-04$ & $3.237 \mathrm{E}+00$ & $2.019 \mathrm{E}-04$ \\
\hline 0.150 & $2.288 \mathrm{E}-02$ & $1.636 \mathrm{E}-04$ & $1.541 \mathrm{E}+00$ & $1.758 \mathrm{E}-04$ \\
\hline 0.250 & $1.835 \mathrm{E}-02$ & $1.374 \mathrm{E}-04$ & $9.660 \mathrm{E}-01$ & $1.477 \mathrm{E}-04$ \\
\hline 0.350 & $1.603 \mathrm{E}-02$ & $1.207 \mathrm{E}-04$ & $7.9235-01$ & $1.298 \mathrm{E}-04$ \\
\hline 0.475 & $1.408 \mathrm{E}-02$ & $1.066 \mathrm{~F}-04$ & $6.768 \mathrm{E}-01$ & $1.146 \mathrm{E}-04$ \\
\hline 0.650 & $1.227 \mathrm{E}-02$ & $9.313 E-05$ & $5.813 E-01$ & $1.001 \mathrm{E}-04$ \\
\hline 0.825 & $1.099 \mathrm{E}-02$ & $8.357 \mathrm{E}-05$ & $5.172 \mathrm{E}-01$ & $8.984 E-05$ \\
\hline 1.000 & $1.002 \mathrm{E}-02$ & $7.622 \mathrm{E}-05$ & $4.700 \mathrm{E}-01$ & $8.194 \mathrm{E}-05$ \\
\hline 1.225 & $9.058 \mathrm{E}-03$ & $6.882 E-05$ & $4.239 \mathrm{E}-01$ & $7.398 \mathrm{E}-05$ \\
\hline 1.475 & $8.246 \mathrm{E}-03$ & $6.250 \mathrm{E}-05$ & $3.860 \mathrm{E}-01$ & $6.718 \mathrm{E}-05$ \\
\hline 1.700 & $7.669 \mathrm{E}-03$ & $5.813 \mathrm{E}-05$ & $3.602 \mathrm{E}-01$ & $6.249 \mathrm{E}-05$ \\
\hline 1.900 & $7.243 \mathrm{E}-03$ & $5.478 \mathrm{E}-05$ & $3.420 \mathrm{E}-01$ & $5.889 \mathrm{E}-05$ \\
\hline 2.100 & $6.882 \mathrm{E}-03$ & $5.176 \mathrm{E}-05$ & $3.268 \mathrm{E}-01$ & $5.564 \mathrm{E}-05$ \\
\hline 2.300 & $6.573 \mathrm{E}-03$ & $4.896 \mathrm{E}-05$ & $3.141 \mathrm{E}-01$ & $5.263 \mathrm{E}-05$ \\
\hline 2.500 & $6.304 \mathrm{E}-03$ & $4.654 \mathrm{E}-05$ & $3.033 \mathrm{E}-01$ & $5.003 \mathrm{E}-05$ \\
\hline 2.700 & $6.072 \mathrm{E}-03$ & $4.445 E-05$ & $2.942 \mathrm{E}-01$ & $4.778 E-05$ \\
\hline 3.000 & $5.776 \mathrm{E}-03$ & $4.196 \mathrm{E}-05$ & $2.830 \mathrm{E}-01$ & $4.511 \mathrm{E}-05$ \\
\hline 3.600 & $5.323 \mathrm{E}-03$ & $3.868 \mathrm{E}-05$ & $2.669 \mathrm{E}-01$ & $4.158 \mathrm{E}-05$ \\
\hline 4.500 & $4.842 E-03$ & $3.485 \mathrm{E}-05$ & $2.521 \mathrm{E}-01$ & $3.746 \mathrm{E}-05$ \\
\hline 5.500 & $4.474 \mathrm{E}-03$ & $3.145 E-05$ & $2.428 \mathrm{E}-01$ & $3.381 E-05$ \\
\hline 6.600 & $4.198 \mathrm{E}-03$ & $2.894 \mathrm{E}-05$ & $2.371 \mathrm{E}-01$ & $3.111 \mathrm{E}-05$ \\
\hline 8.600 & $3.898 \mathrm{E}-03$ & $2.578 \mathrm{E}-05$ & $2.325 \mathrm{E}-01$ & $2.771 E-05$ \\
\hline
\end{tabular}

2" to the side

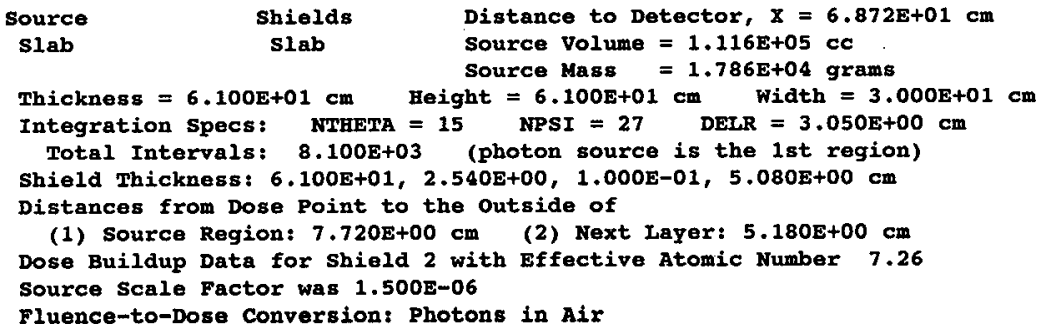

$\begin{array}{lcllc}\text { Average } & \text { Source Total } & \text { Fluence to } & \text { EnergY Fluence } & \text { Dose Rate } \\ \text { F, MeV } & \text { photons/sec } & \text { Dose Factor } & \mathrm{MeV} / \mathrm{sq} \cdot \mathrm{cm} / \mathrm{sec} & \mathrm{R} / \mathrm{hr}\end{array}$


SNF-3328 REV 0

\begin{tabular}{lllll}
\hline 0.015 & $1.798 \mathrm{E}+07$ & $8.183 \mathrm{E}-05$ & $4.919 \mathrm{E}-19$ & $4.025 \mathrm{E}-23$ \\
0.025 & $9.529 \mathrm{E}+06$ & $1.656 \mathrm{E}-05$ & $7.181 \mathrm{E}-04$ & $1.189 \mathrm{E}-08$ \\
0.035 & $4.263 \mathrm{E}+07$ & $6.084 \mathrm{E}-06$ & $3.885 \mathrm{E}+00$ & $2.364 \mathrm{E}-05$ \\
0.045 & $5.573 \mathrm{E}+06$ & $3.203 \mathrm{E}-06$ & $6.422 \mathrm{E}+00$ & $2.057 \mathrm{E}-05$ \\
0.055 & $2.787 \mathrm{E}+06$ & $2.216 \mathrm{E}-06$ & $8.751 \mathrm{E}+00$ & $1.939 \mathrm{E}-05$ \\
0.065 & $2.326 \mathrm{E}+06$ & $1.827 \mathrm{E}-06$ & $1.106 \mathrm{E}+01$ & $2.022 \mathrm{E}-05$ \\
0.075 & $2.067 \mathrm{E}+06$ & $1.664 \mathrm{E}-06$ & $1.246 \mathrm{E}+01$ & $2.074 \mathrm{E}-05$ \\
0.085 & $2.023 \mathrm{E}+06$ & $1.603 \mathrm{E}-06$ & $1.476 \mathrm{E}+01$ & $2.367 \mathrm{E}-05$ \\
0.095 & $1.637 \mathrm{E}+06$ & $1.592 \mathrm{E}-06$ & $1.416 \mathrm{E}+01$ & $2.255 \mathrm{E}-05$ \\
0.150 & $1.074 \mathrm{E}+07$ & $1.728 \mathrm{E}-06$ & $1.517 \mathrm{E}+02$ & $2.621 \mathrm{E}-04$ \\
0.250 & $2.837 \mathrm{E}+06$ & $1.935 \mathrm{E}-06$ & $6.608 \mathrm{E}+01$ & $1.279 \mathrm{E}-04$ \\
0.350 & $1.148 \mathrm{E}+06$ & $2.019 \mathrm{E}-06$ & $3.637 \mathrm{E}+01$ & $7.344 \mathrm{E}-05$ \\
0.475 & $9.253 \mathrm{E}+05$ & $2.043 \mathrm{E}-06$ & $3.788 \mathrm{E}+01$ & $7.739 \mathrm{E}-05$ \\
0.650 & $4.595 \mathrm{E}+08$ & $2.029 \mathrm{E}-06$ & $2.416 \mathrm{E}+04$ & $4.903 \mathrm{E}-02$ \\
0.825 & $1.401 \mathrm{E}+06$ & $1.983 \mathrm{E}-06$ & $8.924 \mathrm{E}+01$ & $1.770 \mathrm{E}-04$ \\
1.000 & $1.899 \mathrm{E}+06$ & $1.923 \mathrm{E}-06$ & $1.422 \mathrm{E}+02$ & $2.734 \mathrm{E}-04$ \\
1.225 & $2.632 \mathrm{E}+06$ & $1.850 \mathrm{E}-06$ & $2.359 \mathrm{E}+02$ & $4.364 \mathrm{E}-04$ \\
1.475 & $2.525 \mathrm{E}+05$ & $1.775 \mathrm{E}-06$ & $2.685 \mathrm{E}+01$ & $4.766 \mathrm{E}-05$ \\
1.700 & $1.761 \mathrm{E}+04$ & $1.712 \mathrm{E}-06$ & $2.135 \mathrm{E}+00$ & $3.655 \mathrm{E}-06$ \\
1.900 & $9.848 \mathrm{E}+02$ & $1.660 \mathrm{E}-06$ & $1.325 \mathrm{E}-01$ & $2.199 \mathrm{E}-07$ \\
2.100 & $6.196 \mathrm{E}+02$ & $1.613 \mathrm{E}-06$ & $9.159 \mathrm{E}-02$ & $1.477 \mathrm{E}-07$ \\
2.300 & $1.181 \mathrm{E}+00$ & $1.592 \mathrm{E}-06$ & $1.903 \mathrm{E}-04$ & $3.030 \mathrm{E}-10$ \\
\hline-0.00 & $5.679 \mathrm{E}+08$ & photons/sec & $2.502 \mathrm{E}+04$ & $5.066 \mathrm{E}-02 \mathrm{R} / \mathrm{hr}$ \\
\hline Totals: & 5 & & & $3.631 \mathrm{E}-09 \mathrm{amp} / \mathrm{kg}$
\end{tabular}

Closing: This is the end of the poxtable exhauster HEPA Case it!

Finish run at $10: 28: 52 \quad 02 / 20 / 98$

Input File (HEPA.) is shown below:

o 2 CSB Portable HEPA Filter with $1.5 \mathrm{~g}$ SNF Fuel (Safety Source)

2 " to the side

EInput IGeom=10, SLTH= $30, Y=61, T=61,2.54,0.1, \quad X=68.72$,

Nshld $=3$, JBuf $=2$, NTheta $=15, \mathrm{NPsi}=27, \mathrm{DelR}=3.0$,

sFact $=1.5 \mathrm{E}-6$, Weight $(472)=2.09$,

Weight $(82)=6930,0,6930$, Weight $(206)=2.78$,

Weight $(319)=6.47$, Weight $(335)=9660,9140$,

Weight $(388)=109$, Weight $(403)=102$,

Weight $(415)=113$, Weight $(418)=10.6 \&$

HEPA $21-0.16$

air $3 \quad 0.0012$

1 duct 9

This is the end of the portable exhauster HEPA Case !!

\&Input Next $=6$ \&

Note: There is a 1 inch gap between the filter and the housing.

The source activities are for one metric ton uranium (1E6 gU). 


\section{REFERENCES}

BNWL-236, 1966, ISOSHLD - A Computer Code for General Purpose Isotope Shielding Analysis, Pacific Northwest Laboratories, Richland, Washington.

BNWL-236-SUP1, 1967, ISOSHLD-II: Code Revision To Include Calculation of Dose Rate From Shielded Bremsstrahlung Sources, Pacific Northwest Laboratories, Richland, Washington.

HNF-SD-SNF-TI-059, 1998, A Discussion on the Methodology for Calculating Radiological and Toxicological Consequences for the Spent Nuclear Fuel Project at the Hanford Site, Rev. 1, Fluor Daniel Hanford, Incorporated, Richland, Washington.

WHC-SD-SQA-CSWD-303, 1989, Validation of ISOSHLD-II, Rev. 0, Westinghouse Hanford Company, Richland, Washington.

WHC-SD-WM-UM-030, 1995, ISO-PC Version 1.98 - User's Guide, Rev. 0, Westinghouse Hanford Company, Richland, Washington. 
SNF-3328 REV 0

This page intentionally left blank. 
SNF-3328 REV 0

\section{APPENDIX C}

KEY INPUT PARAMETERS FOR THERMAL RUNAWAY FUEL REACTIONS INSIDE A MULTI-CANISTER OVERPACK 
SNF-3328 REV 0

This page intentionally left blank. 


\section{APPENDIX C}

\section{KEY INPUT PARAMETERS FOR THERMAL RUNAWAY FUEL REACTIONS INSIDE A MULTI-CANISTER OVERPACK}

Key input parameters used in the analysis for the bounding multi-canister overpack (MCO) with Mark IV fuel under off-normal events at the Canister Storage Building (CSB) are shown in Table C-1. Notes are provided following the table. Most parameters are for one scrap basket and four fuel baskets, but some of the key data, like water content in the uranium hydrate, is for two scrap baskets and three fuel baskets in order to provide bounding MCO conditions.

Table C-1. Key Input Parameters for CSB Thermal Runaway Analysis. (2 sheets)

\begin{tabular}{|c|c|c|}
\hline Parameter & Value & Reference \\
\hline \multicolumn{3}{|c|}{ HEAT GENIERAMION P AR MMEMERS power, reaction ared, reaction rate } \\
\hline $\begin{array}{l}\text { Bounding decay power ( } 776 \mathrm{~W} \text { for five } \\
\text { fuel baskets) }\end{array}$ & $740.8 \mathrm{~W}$ per $\mathrm{MCO}$ & $\begin{array}{l}\text { HNF-SD-SNF-TI-015 } \\
\text { Note } 1\end{array}$ \\
\hline Scrap fuel reaction surface area & $4.5 \mathrm{~m}^{2}$ & HNF-SD-SNF-TI-015 \\
\hline Fuel reaction area & $3.16 \mathrm{~m}^{2}$ & HNF-SD-SNF-TI-015 \\
\hline Reaction rate multiplier & 10 & HNF-SD-SNF-TI-015 \\
\hline $\begin{array}{l}\text { Rate multiplier for uranium hydride } \\
\text { (bounding hydride mass for MCO with } 2 \\
\text { scrap baskets) }\end{array}$ & $\begin{array}{c}12 \text { - fuel basket } \\
12 \text { - scrap basket } \\
(5.13 \text { kg per } \mathrm{MCO})\end{array}$ & $\begin{array}{l}\text { HNF-SD-SNF-TI-015 } \\
\text { Note } 2\end{array}$ \\
\hline \multicolumn{3}{|c|}{ 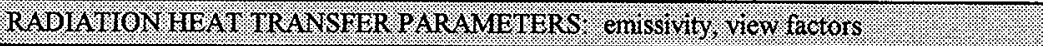 } \\
\hline Scrap fuel emissivity & 0.7 & HNF-SD-SNF-TI-015 \\
\hline Cladding emissivity & 0.43 & $\begin{array}{l}\text { HNF-SD-SNF-TI-015 } \\
\text { Note } 3\end{array}$ \\
\hline Inner shield plug emissivity & 0.3 & HNF-SD-SNF-TI-015 \\
\hline MCO wall emissivity & 0.3 & HNF-SD-SNF-TI-015 \\
\hline $\begin{array}{l}\text { Cask, MCO bottom, and outer shield plug } \\
\text { emissivity }\end{array}$ & 0.25 & $\begin{array}{l}\text { FAI } / 98-40 \\
\text { Note } 4\end{array}$ \\
\hline $\begin{array}{l}\text { View factors and gap distances between } \\
\text { fuel rods and MCO wall }\end{array}$ & $8 \times 8$ matrix & $\begin{array}{l}\text { FAI } / 98-40 \\
\text { Note } 5\end{array}$ \\
\hline \multicolumn{3}{|c|}{ 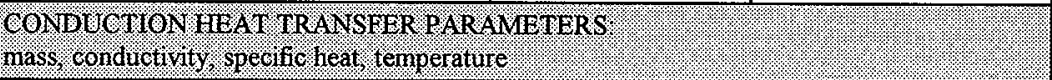 } \\
\hline Effective fuel-cladding mass density & $18,573.3 \mathrm{~kg} / \mathrm{m}^{3}$ & Note 6 \\
\hline
\end{tabular}


Table C-1. Key Input Parameters for CSB Thermal Runaway Analysis. (2 sheets)

\begin{tabular}{|c|c|c|}
\hline Parameter & Value & Reference \\
\hline Uranium (scrap) mass density at $100^{\circ} \mathrm{C}$ & $19,000 \mathrm{~kg} / \mathrm{m}^{3}$ & $\begin{array}{l}\text { Holden } 1958 \\
\quad \text { Note } 7\end{array}$ \\
\hline Stainless steel mass density at $100^{\circ} \mathrm{C}$ & $8,000 \mathrm{~kg} / \mathrm{m}^{3}$ & $\begin{array}{l}\text { TID } 26666 \\
\text { Note } 8\end{array}$ \\
\hline $\begin{array}{l}\text { Maximum fuel mass load } \\
\text { (Mark IV fuel) }\end{array}$ & $\begin{array}{c}980 \mathrm{~kg} \text { - scrap } \\
\text { basket } \\
1,268 \mathrm{~kg} \text { - fuel } \\
\text { basket } \\
6,052 \mathrm{~kg} \text { per MCO }\end{array}$ & HNF-SD-SNF-TI-015 \\
\hline Effective fuel/clad thermal conductivity & $24.2 \mathrm{~W} / \mathrm{m} / \mathrm{K}$ & Note 9 \\
\hline Stainless steel thermal conductivity & $16.0 \mathrm{~W} / \mathrm{m} / \mathrm{K}$ & TID 26666 \\
\hline $\begin{array}{l}\text { Effective fuel-cladding and uranium } \\
\text { specific heat }\end{array}$ & $122.67 \mathrm{~J} / \mathrm{kg} / \mathrm{K}$ & Note 10 \\
\hline Stainless steel specific heat & $500.0 \mathrm{~J} / \mathrm{kg} / \mathrm{K}$ & TID 26666 \\
\hline $\begin{array}{l}\text { Free residual water in cracks after } \mathrm{CVD} \text {, } \\
\text { arriving at } \mathrm{CSB}\end{array}$ & $0.2 \mathrm{~kg}$ per $\mathrm{MCO}$ & HNF-SD-SNF-TI-015 \\
\hline Water in uranium hydrates, $\mathrm{UO}_{3} \cdot 2 \mathrm{H}_{2} \mathrm{O}$ & $\begin{array}{c}1.19 \mathrm{~kg} \\
\text { per MCO with } 2 \\
\text { SBs }\end{array}$ & $\begin{array}{c}\text { HNF-SD-SNF-TI-015 } \\
\text { Note } 11\end{array}$ \\
\hline $\begin{array}{l}\text { Water in aluminum hydroxide, and } \\
\text { aluminum+iron hydrates in sludge }\end{array}$ & $\begin{array}{c}3.45 \mathrm{~kg} \\
\text { per MCO with } 2 \\
\text { SBs }\end{array}$ & HNF-SD-SNF-TI-015 \\
\hline Bounding MCO wall temperature & $132^{\circ} \mathrm{C}$ & CSB-HV-0014 \\
\hline \multicolumn{3}{|c|}{$\begin{array}{l}\text { GONYECTIVE IEAT AND MASS TRANSFER PARA AWETERS. } \\
\text { gas volume, flow area, flow rate }\end{array}$} \\
\hline Scrap basket gas volume & $0.153 \mathrm{~m}^{3}$ & Note 12 \\
\hline Upper fuel ( 2 fuel baskets) volume & $0.186 \mathrm{~m}^{3}$ & Note 13 \\
\hline Lower fuel ( 2 fuel baskets) volume & $0.199 \mathrm{~m}^{3}$ & Note 14 \\
\hline Fine scrap porosity & 0.40 & Note 15 \\
\hline Course scrap porosity & 0.723 & Note 16 \\
\hline Flow area in scrap basket bottom & $0.013 \mathrm{~m}^{2}$ & Note 17 \\
\hline
\end{tabular}

$$
\begin{aligned}
& \text { CSB = Canister Storage Building. } \\
& \text { CVD = cold vacuum drying. } \\
& \mathrm{MCO}=\text { multi-canister overpack. } \\
& \mathrm{SB}=\text { scrap basket. }
\end{aligned}
$$


Note 1 Bounding decay heat rate - The bounding decay power (i.e., decay heat rate) is given as $776 \mathrm{~W}$ per MCO with five Mark IV fuel baskets ( $155.2 \mathrm{~W}$ per fuel basket or $620.8 \mathrm{~W}$ for four fuel baskets), so the specific heat rate is $0.1224 \mathrm{~W} / \mathrm{kgU}$ for Mark IV fuel (HNF-SD-SNF-TI-015). The scrap basket for Mark IV fuel has a maximum fuel loading of $980 \mathrm{~kg}$ (HNF-SD-SNF-TI-015), so the scrap basket has a maximum decay power of about $120 \mathrm{~W}(980 \mathrm{kgU} \times 0.1224 \mathrm{~W} / \mathrm{kgU})$. Hence, the bounding decay power (i.e., decay heat rate) is $740.8 \mathrm{~W}$ per MCO $(620.8 \mathrm{~W}+120 \mathrm{~W})$ with four Mark IV fuel baskets and one Mark IV scrap basket.

Note 2 Rate multiplier for uranium hydride $\left(\mathrm{UH}_{3}\right)$ - Oxygen (and water) reacts faster with uranium hydride than with just uranium metal. The current hydride model (HNF-2256) calculates the enhanced reaction rate by increasing the effective surface area of reaction through the use of a rate multiplier. In the current hydride model, the hydrides in the MCO are strongly coupled thermally to the uranium fuel. Hence, any increase in hydride temperature is dissipated in the larger uranium fuel mass, resulting in a temperature increase for the entire fuel element. This analysis uses hydride rate multipliers that are shown in HNF-SD-SNF-TI-015, Spent Nuclear Fuel Project Technical Databook. The bounding mass loading of $\mathrm{UH}_{3}$ in the $\mathrm{MCO}$ is $5.13 \mathrm{~kg}$ (1.97 kg in three fuel baskets, $3.16 \mathrm{~kg}$ in two scrap baskets) (HNF-SD-SNF-TI-015). The computer simulations used a constant rate multiplier of 12 in the simulations for all time, which means that the hydride mass consumption was turned off in the simulations in order to be conservative and not count on a depleting hydride mass for safety.

Note 3 Cladding emissivity - Cladding emissivity is used for the combined fuel-cladding composite heat element in the model because the cladding covers the fuel element on the outside, keeping the uranium fuel hidden. The emissivity of Zircaloy-2 ranges from 0.43 at high temperatures or thin oxide coating to 0.7 (HNF-SD-SNF-TI-015) at normal temperatures and thicker zirconium oxide layers. The more conservative lower value of 0.43 was chosen, which will cause less heat to radiate from the fuel-cladding heat elements to the wall.

Note 4 Cask, MCO bottom, and outer shield plug emissivity - The emissivity of the cask, MCO bottom plate, and the outer shield plug was decreased to 0.25 from 0.30 in HNF-SD-SNF-TI-015 in order to conservatively reduce the heat removal rate from the MCO (HNF-2256) and cask.

Note 5 View factors and gap distances between fuel rods and MCO wall - The view factors and gap distances between the fuel rods in the fuel basket and the MCO wall, which are used in the radiative heat transfer model and convection heat transfer model for an MCO fuel basket, are documented in the HANSF code document (FAI/98-40). However, the view factors used in this analysis differ slightly from those in the code document. The view factors for this analysis, and for the two-scrap basket report (HNF-2256), are described in detail in Appendix D of HNF-SD-SNF-CN-023, Thermal Analysis of Cold Vacuum Drying of Spent Nuclear Fuel. 
Note 6 Effective fuel-cladding mass density - Since the cladding volume is merged with the fuel volume in the HANSF code (FAI/98-40), an effective mass density is needed for the combined fuel and cladding. To simplify the derivation, the inner fuel element and cladding are assumed to have the same effective mass density as the outer fuel element and its cladding. The total volume for the fuel elements and cladding in the HANSF code is $0.31752 \mathrm{~m}^{3}$ (FAI/98-40). Since the maximum fuel mass for 216 Mark IV elements (four fuel baskets) is $5,072 \mathrm{~kg}$ (23.48 kg per element [HNF-SD-SNF-TI-015]), the volume of the fuel is about $0.26695 \mathrm{~m}^{3}$, which is calculated by dividing the volume by the fuel density, $19,000 \mathrm{~kg} / \mathrm{m}^{3}$ at $100^{\circ} \mathrm{C}$ (Holden 1958). The cladding volume is found by subtracting the fuel volume from the total volume:

$$
V_{\text {cladding }}=V_{\text {total }}-V_{\text {fuel }}=0.31752 \mathrm{~m}^{3}-0.26695 \mathrm{~m}^{3}=0.05057 \mathrm{~m}^{3}
$$

Multiplying the density of the Zircaloy-2 cladding, $6,541 \mathrm{~kg} / \mathrm{m}^{3}$ (UNI-M-61), by the volume of cladding gives a cladding mass of $330.8 \mathrm{~kg}$ :

$$
\mathrm{M}_{\text {cladding }}=6,541 \mathrm{~kg} / \mathrm{m}^{3} \times 0.26695 \mathrm{~m}^{3}=330.8 \mathrm{~kg} .
$$

For thermal calculations, it is essential that the effective mass (and density) and specific heat product be conserved and, therefore, equal to the sum of the fuel and cladding parts:

$$
\left(\mathrm{M} \mathrm{x} \mathrm{C}_{\mathrm{p}}\right)_{\text {eff }}=\mathrm{M}_{\text {fuel }} \times \mathrm{C}_{\mathrm{p} \text {-fuel }}+\mathrm{M}_{\mathrm{cladding}} \times \mathrm{C}_{\mathrm{p} \text {-cladding }}
$$

where $\mathrm{C}_{\text {p-fuel }}=122.67 \mathrm{~J} / \mathrm{kg} / \mathrm{K}(\mathrm{HNF}-\mathrm{SD}-\mathrm{SNF}-\mathrm{TI}-015)$ and $\mathrm{C}_{\text {p-cladding }}=306.1 \mathrm{~J} / \mathrm{kg} / \mathrm{K}$ (WCAP-3269-41).

For convenience, the effective specific heat is set equal to the specific heat of uranium and the effective mass calculated, which can be done since it's the product that must be conserved. Hence, the equation above becomes the following after dividing by the uranium specific heat:

$$
\begin{aligned}
\mathrm{M}_{\mathrm{eff}} & =\mathrm{M}_{\text {fuel }}+\mathrm{M}_{\text {cladding }} \times \mathrm{C}_{\mathrm{p}-\text { cladding }} / \mathrm{C}_{\mathrm{p} \text {-fuel }} \\
& =5,072 \mathrm{~kg}+330.8 \mathrm{~kg} \times(306.1 \mathrm{~J} / \mathrm{kg} / \mathrm{K} \div 122.67 \mathrm{~J} / \mathrm{kg} / \mathrm{K}) \\
& =5,897.4 \mathrm{~kg} .
\end{aligned}
$$

Since the Zircaloy- 2 cladding has a higher heat capacity than uranium, the effective mass (in regards to mass times heat capacity product) is larger than just the sum of the masses. Using the calculated effective combined mass of the fuel and cladding above, the effective density of the fuel-cladding composite is simply the effective mass divided by the total volume:

$$
\rho_{\text {eff }}=M_{\text {eff }} / V_{\text {total }}
$$




$$
\begin{aligned}
& =5,897.4 \mathrm{~kg} / 0.31752 \mathrm{~m}^{3} \\
& =18,573.3 \mathrm{~kg} / \mathrm{m}^{3}
\end{aligned}
$$

The temperature dependence of densities, specific heats, and conductivities is ignored in the analysis because the HANSF code does not have the capability to handle temperature-dependent material properties (FAI/98-40). In order to be consistent, the material parameter values were chosen at around $100^{\circ} \mathrm{C}$ and rounded off.

Note 7 Uranium mass density - The mass density of uranium is about $19,000 \mathrm{~kg} / \mathrm{m}^{3}$ at $100{ }^{\circ} \mathrm{C}$. Since the HANSF code (FAI/98-40) does not include temperature-dependent material parameters, approximate values are used. The standard reference temperature of $100^{\circ} \mathrm{C}$ was chosen because it's higher than normal operating temperatures but lower than most temperatures during off-normal conditions.

Note 8 Stainless steel mass density - The mass density of 304L stainless steel is about $8,000 \mathrm{~kg} / \mathrm{m}^{3}$ at $100{ }^{\circ} \mathrm{C}$ (TID 26666). See the discussion above in Note 10 about temperature-dependent material properties.

Note 9 Effective fuel-cladding thermal conductivity - Since the fuel elements and cladding are combined in the model, an effective thermal conductivity is needed to represent the combined materials. Although the cladding has a lower conductivity, the conductivity of both metals is high, so the calculation of an effective thermal conductivity is not important to the calculational results.

The effective thermal conductivity, $\mathrm{K}_{\mathrm{eff}}$, was estimated using the following equation, which is valid for conductors connected in series such as the fuel and cladding in the radial direction:

$$
\mathrm{x}_{\text {tota }} / \mathrm{K}_{\mathrm{eff}}=\mathrm{x}_{\text {fuef }} / \mathrm{K}_{\text {fuel }}+\mathrm{x}_{\text {cladding }} / \mathrm{K}_{\text {cladding }}
$$

where

$$
\begin{aligned}
& \mathrm{K}_{\text {tuel }}=\text { thermal conductivity of spent fuel }(26.9 \mathrm{~W} / \mathrm{m} / \mathrm{K} \text { [Kaufman 1962]) } \\
& \mathrm{K}_{\text {cladding }}=\text { thermal conductivity of Zircaloy-2 cladding }(13.4 \mathrm{~W} / \mathrm{m} / \mathrm{K} \\
& \text { [WCAP-3269-41]) } \\
& \mathrm{X}_{\text {total }}=\text { total radial thickness of fuel element and cladding }\left(\mathrm{X}_{\text {fuel }}+\mathrm{X}_{\text {cladding }}\right) .
\end{aligned}
$$

Since the cladding mass is about $7 \%$ of the spent fuel mass

(HNF-SD-SNF-TI-015) and the cladding density is about one-third of the fuel density, the cladding was estimated to have about $20 \%(\sim 7 \% \times 3)$ of the combined fuel-cladding volume for both inner and outer fuel elements on the average. The thickness is proportional to the volume, therefore the cladding thickness is estimated to be $0.2 \times \mathrm{x}_{\text {fucl }}$, making the total thickness $1.2 \times \mathrm{x}_{\text {fucl. }}$. Substituting these 
Note 10 Effective fuel-cladding (and uranium) specific heat - As discussed in Note 9, which derived the effective mass density, the effective specific heat for the combined fuel and cladding elements was chosen to be equal to the uranium specific heat, $122.67 \mathrm{~J} / \mathrm{kg} / \mathrm{K}$ at $100^{\circ} \mathrm{C}$ (Kaufman 1962). This choice was in conjunction with the effective mass density calculation since it is the product of mass density and specific heat that must be conserved (i.e., the specific heat of the cladding is included in the effective mass density [see Note 9]).

Note 11 The water in hydrates was increased to $1.16 \mathrm{~kg}$ for this report in order to provide extra margin over the hydrate water reported elsewhere (e.g., $0.65 \mathrm{~kg}$ [HNF-SD-SNF-TI-015]). However, for the "normal" suite of 13 runs, case 0 , which simulates a complete drying cycle with tests, the hydrate water was reduced to $0.72 \mathrm{~kg}$ (HNF-1527) because the decomposing hydrates can affect the rebound pressure tests after vacuum drying.

Note 12 Scrap basket volume - Based on the latest design drawings (HNF-SD-SNF-DR-003), the scrap basket has a free volume of $0.153 \mathrm{~m}^{3}$ when it contains $980 \mathrm{~kg}$ of uranium metal. This volume includes the $0.0533-\mathrm{m}$ (2.1-in) gap between the scrap basket and the bottom of the MCO assembly (below the shield plug) and $0.0159 \mathrm{~m}^{3}$ void space (manifold) in the MCO assembly (HNF-2833) that is always open to the MCO on top. The scrap basket volume excludes the volume of the stainless steel parts, support post inner volumes, and insert inner volume. The total length of the inner MCO is $3.6 \mathrm{~m}$ (141.85 in.) which includes a $0.0533-\mathrm{m}$ (2.1-in.) gap above the scrap basket and a 0.0381 -m (1.5-in) gap between the bottom fuel basket and the top of MCO bottom plate. The inner radius of the $\mathrm{MCO}$ is $0.2921 \mathrm{~m}(11.5 \mathrm{in}$.).

Note 13 Upper fuel volume (two fuel baskets) - The two upper fuel baskets are combined into one control volume in the HANSF model (FAI/98-40). The free volume for the two fuel baskets, excluding the stainless steel volume and inner volume of support posts and insert, is $0.186 \mathrm{~m}^{3}$ based on the design drawings (HNF-SD-SNF-DR-003).

Note 14 Lower fuel volume (two fuel baskets) - The bottom two fuel baskets have a combined free volume of $0.199 \mathrm{~m}^{3}$. This volume includes the $0.0381-\mathrm{m}(1.5-\mathrm{in})$ gap below the bottom fuel basket and above the MCO bottom plate with a volume of $0.013 \mathrm{~m}^{3}$ and excludes the stainless steel volume and inner volume of support posts and insert.

Note 15 Fine scrap porosity - The porosity of the fine scrap fuel $(0.25 \mathrm{in.}$ to $1 \mathrm{in}$. maximum dimension) in the scrap basket is the void or gas space fraction (void volume divided by total volume) in the total scrap volume when the scrap is completely dry. The porosity of porous media such as a course sand is about 0.35 
Note 16 Course scrap porosity - The largest dimension of the course scrap will not be less than 1 in. or greater than 3 in. The total open volume of an empty scrap basket is $0.16762 \mathrm{~m}^{3}$ (total inner volume minus the insert and copper fin volumes). The fine scrap volume is $0.01592 \mathrm{~m}^{3}$, and the course scrap volume is $0.1517 \mathrm{~m}^{3}$. The total solid scrap volume is calculated by dividing the total bounding scrap mass, $980 \mathrm{~kg}$, by the fuel mass density, $19,000 \mathrm{~kg} / \mathrm{m}^{3}$, resulting in a total solid volume of $0.05158 \mathrm{~m}^{3}$. The solid (fuel) volume in the fine portion is 0.6 (1-porosity) times the total fine scrap volume, $0.01592 \mathrm{~m}^{3}$, resulting in $0.009552 \mathrm{~m}^{3}$. Hence, the coarse scrap solid volume is $0.05158 \mathrm{~m}^{3}$ minus the fine scrap solid volume, $0.009552 \mathrm{~m}^{3}$, for a value of $0.042028 \mathrm{~m}^{3}$. Dividing the coarse scrap solid volume by the total coarse scrap volume gives the solid fraction of $0.042028 \mathrm{~m}^{3} \div$ $0.1517 \mathrm{~m}^{3}=0.27707$ for the coarse portion. Hence, the porosity of the coarse scrap is just $1.0-0.27707$ for a coarse scrap porosity value of 0.72293 .

Note 17 Flow area in scrap basket bottom - The flow area at the bottom of the scrap basket is the only flow area available for the scrap and the total gas release out of the top of the MCO during vacuum drying. Since copper shims have been added between the outer scrap basket and MCO wall, the upward flow has nowhere to go except through the bottom of the scrap basket. The scrap basket bottom has 108 open 0.5 -in. diameter holes (HNF-SD-SNF-DR-003) in it. Hence, the total flow area is calculated as follows:

$$
\begin{aligned}
& A_{\mathrm{SB}}=108 \times 3.14159 \times(0.5 \times 0.0254 / 2)^{2} \mathrm{~m}^{2} \\
& =108 \times 1.2668 \times 10^{-4} \mathrm{~m}^{2} \\
& =0.0137 \mathrm{~m}^{2}
\end{aligned}
$$

which was truncated to $0.013 \mathrm{~m}^{2}$ in order to constrict the gas flow through the scrap basket a little more to account for the wire screen covering part of the holes.

\section{REFERENCES}

CSB-HV-0014, 1998, Long Term MCO Temperature Without Cooling in the Sampling Station, Fluor Daniel Hanford, Incorporated, Richland, Washington.

FAI/98-40, 1998, Hanford Spent Nuclear Fuel Safety Analysis Model HANSF 1.2: User's Manual, Rev. 0, Fauske \& Associates, Incorporated, Burr Ridge, Illinois.

HNF-1527, 1997, Estimates of Particulate Mass in Multi-Canister Overpacks, Rev. 0, Fluor Daniel Hanford, Incorporated, Richland, Washington. 
HNF-2256, 1998, Simulation of Normal and Off-Normal Multi-Canister Overpack Behavior, Rev. 2, Fluor Daniel Hanford, Incorporated, Richland, Washington.

HNF-2833, 1998, Inert Gas Requirements for Cask Loading, Rev. 0, Fluor Daniel Hanford, Incorporated, Richland, Washington

HNF-SD-SNF-CN-017, Fuel Surface Area, HNF-SD-SNF-CN-017, Rev. 3, Fluor Daniel Hanford, Incorporated, Richland, Washington.

HNF-SD-SNF-CN-023, 1998, Thermal Analysis of Cold Vacuum Drying of Spent Nuclear Fuel, Rev. 1, Fluor Daniel Hanford, Incorporated, Richland, Washington.

HNF-SD-SNF-CSER-010, 1998, Criticality Safety Evaluation Report for the K Basin Fuel Retrieval Subproject, Rev. 0, Fluor Daniel Hanford, Incorporated, Richland, Washington.

HNF-SD-SNF-DR-003, 1998, Multi-Canister Overpack Design Report, Rev. 1, Fluor Daniel Hanford, Incorporated, Richland, Washington.

HNF-SD-SNF-TI-015, 1998, Spent Nuclear Fuel Project Technical Databook, Rev. 6, Fluor Daniel Hanford, Incorporated, Richland, Washington.

Holden, A. N., 1958, Physical Metallurgy of Uranium, Addison-Wesley Publishing Company, Reading, Massachusetts.

Kaufman, A. R., 1962, Nuclear Reactor Fuel Elements, Interscience Publication, New York, New York.

TID 26666, 1987, Nuclear Systems Material Handbook, Volume 1, "Design Data," Oak Ridge National Laboratory, Oak Ridge, Tennessee.

UNI-M-61, 1979, Fuels Engineering Technical Handbook, United Nuclear Industries, Richland, Washington.

WCAP-3269-41, 1965, Physical and Mechanical Properties of Zircaloy-2 and 4, Westinghouse Electric Corporation, Pittsburgh, Pennsylvania. 
SNF-3328 REV 0

APPENDIX D

PEER REVIEW CHECKLISTS 
SNF-3328 REV 0

This page intentionally left blank. 
SNF-3328 REV 0

Please note:

All of the calculations for this SNF-3328, Canister Storage Building Design Basis Accident Analysis Documentation, except for those related to Chapter 6.0, "Calculation for Thermal Runaway Reactions Inside the Multi-Canister Overpack," were completed on or before December 23, 1998.

Schedule restraints for document HNF-3553, Spent Nuclear Fuel Project Final Safety Analysis Report, made it necessary to divert SNF-3328 resources to support HNF-3553 deadlines. During efforts to complete HNF-3553, Annex A, "Canister Storage Building Final Safety Analysis Report," Chapter A3.0, "Hazard and Accident Analyses," changes to the thermal runaway reaction accident scenario were deemed necessary. Changes to the calculations were made on January 5, 1999 and February 11, 1999. Those changes were subsequently made to SNF-3328, Chapter 6.0.

A second peer review of Chapter 6.0 was performed to verify that all criteria are still met. The peer review checklist for the second review is included as page D-7a in this appendix. Additionally, due to the delay in issuance of SNF-3328, the peer reviewers rechecked their respective chapters in mid-February and resigned their checklists at that time.

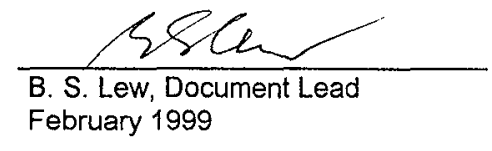




\section{SNF-3328 REV 0}

This page intentionally left blank. 


\section{CHECKLIST FOR PEER REVIEW}

Document Reviewed: $\quad$ SNF-3328, Rev. 0, Canister Storage Building Design Basis Accident Analysis Documentation, Chapter 2.0, "Rearrangement of MultiCanister Overpack Internals"

Scope of Review: Entire chapter

Author: W. T. Watson

Yes No NA

[ ] [ ] [X] * Previous reviews complete and cover analysis, up to scope of this review,

[X] [ ] [ ] Problem completely defined.

[X] [ ] [ ]

$[X][]][]$

[]$\left[\begin{array}{ll}{[} & {[}\end{array}\right]$

[ ] [ ] $[X]$

[X] [ ] [ ]

[][]$,[]$

[ ] [ ] [X]

[ ] [ ] $\not \subset]$

[ ] [ ] $[X]$

[ ] [ ] [X]

[ [ ] [X]

[ ] [ ] [X]

$[X][][]$

[X] [ ] [ ]

[X] [ ] [ ]

[ ] [X] *

Accident scenarios developed in a clear and logical manner.

Necessary assumptions explicitly stated and supported.

Computer codes and data files documented.

Data used in calculations explicitly stated in document.

Data checked for consistency with original source information as applicable.

Mathematical derivations checked including dimensional consistency of results.

Models appropriate and used within range of validity or use outside range of established validity justified.

Hand calculations checked for errors. Spreadsheet results should be treated exactly the same as hand calculations.

Software input correct and consistent with document reviewed.

Software output consistent with input and with results reported in document reviewed.

Limits/criteria/guidelines applied to analysis results are appropriate and referenced. Limits/criteria/guidelines checked against references.

Safety margins consistent with good engineering practices.

Conclusions consistent with analytical results and applicable limits.

Results and conclusions address all points required in the problem statement. Format consistent with appropriate NRC Regulatory Guide or other standards Review calculations, comments, and/or notes are attached.

\section{I ] [ ] Document approved.}

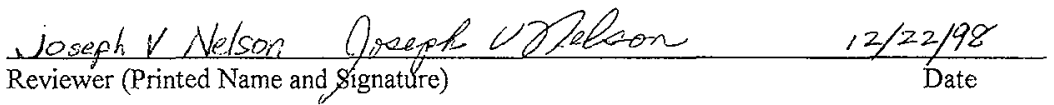

* Any calculations, comments, or notes generated as part of this review should be signed, dated and attached to this checklist. Such material should be labeled and recorded in such a manner as to be intelligible to a technically qualified third party. 


\section{CHECKLIST FOR PEER REVIEW}

Document Reviewed: SNF-3328, Rev. 0, Canister Storage Building Design Basis Accident Analysis Documentation, Chapter 2.0, "Rearrangement of MultiCanister Overpack Internals"

Scope of Review: Entire chapter

Author: $\quad$ W. T. Watson

\section{Yes No NA}

[X] [ ] [ ]*

R] [ ] [ ]

$[\forall][][]$

$[x][]$

[ ] [ ] $[x]$

$[x][][]$

b] [ ] [ ]

[ ] [ ] [x]

[ ] [ ] [ ]

[ ] [ ] $[x]$

[ ] [ ] $[X]$

[ ] [ ] [ $[\mathrm{l}$

[][]$[x]$

$\times][][]$

$[x][][]$

$[x[][]$

$X][][]$

$[x][]^{*}$

Previous reviews complete and cover analysis, up to scope of this review, with no gaps.

Problem completely defined.

Accident scenarios developed in a clear and logical manner.

Necessary assumptions explicitly stated and supported.

Computer codes and data files documented.

Data used in calculations explicitly stated in document.

Data checked for consistency with original source information as applicable.

Mathematical derivations checked including dimensional consistency of results.

Models appropriate and used within range of validity or use outside range of established validity justified.

Hand calculations checked for errors. Spreadsheet results should be treated exactly the same as hand calculations.

Software input correct and consistent with document reviewed.

Software output consistent with input and with results reported in document reviewed.

Limits/criteria/guidelines applied to analysis results are appropriate and referenced. Limits/criteria/guidelines checked against references.

Safety margins consistent with good engineering practices.

Conclusions consistent with analytical results and applicable limits.

Results and conclusions address all points required in the problem statement.

Format consistent with appropriate NRC Regulatory Guide or other standards

Review calculations, comments, and/or notes are attached. Conven $t$ were incerponcte-d.

\section{4 [ ] [ ] Document approved.}

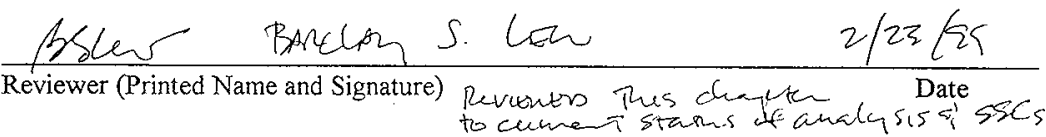

* Any calculations, comments, or notes generated as part of this review should be signed, dated and attached to this checklist. Such material should be labeled and recorded in such a manner as to be intelligible to a technically qualified third party. for chajke $2 s_{i}^{\prime} 4$ of CSB Pan 


\section{SNF-3328 REV 0}

This page intentionally left blank. 


\section{CHECKLIST FOR PEER REVIEW}

Document Reviewed: SNF-3328, Rev. 0, Canister Storage Building Design Basis Accident Analysis Documentation, Chapter 3.0, "Gaseous Release from the Multi-Canister Overpack"

Scope of Review: Entire chapter

Author: $\quad$ S. D. Kopelic

Yes No NA

[X] [ ] [ ] * Previous reviews complete and cover analysis, up to scope of this review,

[X] [ ] [ ] Problem completely defined.

[x] [ ] [ ] Accident scenarios developed in a clear and logical manner.

[x] [ ] [ ] Necessary assumptions explicitly stated and supported.

[ ] [ ] [X] Computer codes and data files documented.

[X] [ ] [ ] Data used in calculations explicitly stated in document.

$[x][$ ] [ ] Data checked for consistency with original source information as applicable.

[ ] [ ] [X] Mathematical derivations checked including dimensional consistency of results.

[X] [ ] [ ] Models appropriate and used within range of validity or use outside range of established validity justified.

[X] [ ] [ ] Hand calculations checked for errors. Spreadsheet results should be treated exactly the same as hand calculations.

[ ] [ ] [x] Software input correct and consistent with document reviewed.

[ ] [ ] [x] Software output consistent with input and with results reported in document reviewed.

[x] [ ] [ ] Limits/criteria/guidelines applied to analysis results are appropriate and referenced. Limits/criteria/guidelines checked against references.

[x] [ ] [ ] Safety margins consistent with good engineering practices.

[x] [ ] [ ] Conclusions consistent with analytical results and applicable limits.

$[x][][]$

[][]$[x]$

[ ] $[X] *$ Review calculations, comments, and/or notes are attached.

\section{[X] [ ] I ] Document approved.}

Paul Pittmann 12-14-98

Rexiewep(Printed Nyme and Signature)

Paul Rovinann 2-18-99

* Any calculations, comments, or notes generated as part of this review should be signed, dated and attached to this checklist. Such material should be labeled and recorded in such a manner as to be intelligible to a technically qualified third party. 


\section{CHECKIIST FOR PEER REVIEW}

Document Reviewed: SNF-3328, Rev. 0, Canister Storage Building Design Basis Accident Analysis Documentation, Chapter 4.0, "Multi-Canister Overpack Internal Hydrogen Explosion"

Scope of Review: Entire chapter
Author:
P. D. Rittmann

Yes No NA

[X] [ ] [ ] * Previous reviews complete and cover analysis, up to scope of this review,

ए] [ ] [ ] $\quad$ Problem completely defined.

$[x][][]$

[x] [ ] [ ]

L] [ ] [ ]

[x] [ ] [ ]

$[X][][]$

$[X][][]$

b. [ ] [ ]

[x] [ ] [ ]

[x] [ ] [ ]

$x][][]$

[X] [ ] [ ]

$\mathbb{W}[\mathrm{]}][\mathrm{]}$

$[x][][]$

[x] [ ] [ ]

$\forall[][]$

$\infty[]^{*}$

Accident scenarios developed in a clear and logical manner.

Necessary assumptions explicitly stated and supported.

Computer codes and data files documented.

Data used in calculations explicitly stated in document.

Data checked for consistency with original source information as applicable.

Mathematical derivations checked including dimensional consistency of results.

Models appropriate and used within range of validity or use outside range of established validity justified.

Hand calculations checked for errors. Spreadsheet results should be treated exactly the same as hand calculations.

Software input correct and consistent with document reviewed.

Software output consistent with input and with results reported in document reviewed.

Limits/criteria/guidelines applied to analysis results are appropriate and referenced. Limits/criteria/guidelines checked against references.

Safety margins consistent with good engineering practices.

Conclusions consistent with analytical results and applicable limits.

Results and conclusions address all points required in the problem statement.

Format consistent with appropriate NRC Regulatory Guide or other standards

Review calculations, comments, and/or notes are attached. All comanen rivetes

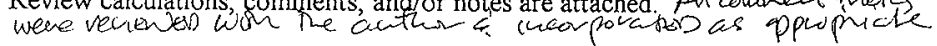

\section{A [ ] [ ] Document approved.}

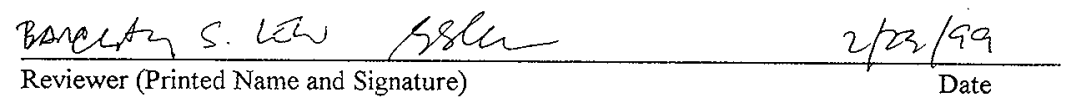

* Any calculations, comments, or notes generated as part of this review should be signed, dated and attached to this checklist. Such material should be labeled and recorded in such a manner as to be intelligible to a technically qualified third party. Spreas sheets weve ubob

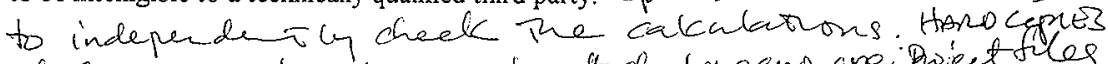
of Pese areve to volumuns to atheh hereand areinproject files on reguers. 


\section{CHECKLIST FOR PEER REVIEW}

Document Reviewed: $\quad$ SNF-3328, Rev. 0, Canister Storage Building Design Basis Accident Analysis Documentation, Chapter 5.0, "Multi-Canister Overpack External Hydrogen Explosion"

Scope of Review: Entire chapter

Author: $\quad$ P. D. Rittmann

Yes No NA

[X] [ ] [ ] * Previous reviews complete and cover analysis, up to scope of this review, with no gaps.

L [ ] [ ] Problem completely defined.

[x] [.] [ ] Accident scenarios developed in a clear and logical manner.

[×] [ ] [ ] Necessary assumptions explicitly stated and supported.

[ $\succ$ [ [ ] [ ] Computer codes and data files documented.

$[x][][]$

$[x][][]$

[x] [ ] [ ]

[x] [ ] [ ]

$[x][][]$

[x] [ ] [ ]

Data used in calculations explicitly stated in document.

Data checked for consistency with original source information as applicable.

Mathematical derivations checked including dimensional consistency of results.

[x] [ ] [ ]

Models appropriate and used within range of validity or use outside range of established validity justified.

Hand calculations checked for errors. Spreadsheet results should be treated exactly the same as hand calculations.

Software input correct and consistent with document reviewed.

[x] [ ] [ ]

[C] [ ] [ ]

[x] [ ] [ ]

Ex] [ ] [ ]

Ex] [ ] [ ]

[A] [ ]*

Software output consistent with input and with results reported in document reviewed.

Limits/criteria/guidelines applied to analysis results are appropriate and referenced. Limits/criteria/guidelines checked against references.

Safety margins consistent with good engineering practices.

Conclusions consistent with analytical results and applicable limits.

Results and conclusions address all points required in the problem statement.

Format consistent with appropriate NRC Regulatory Guide or other standards

Revievy calculations, comments, and/or notes are attached. AM $i$, notes were vevieass

\section{b [ ] [ ]}

Document approved.

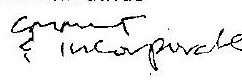

wis sthe anth

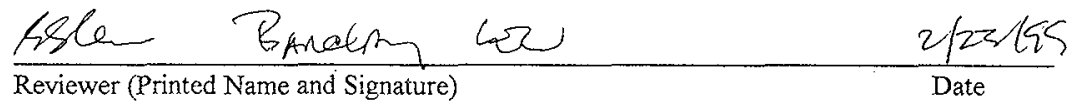

* Any calculations, comments, or notes generated as part of this review should be signed, dated and attached to this checklist. Such material should be labeled and recorded in such a manner as to be intelligible to a technically qualified third party. spyeas sheet wane us oro

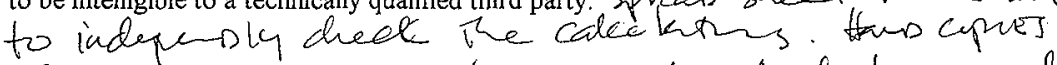
of Thos were... tor volumions to atheh here on lane

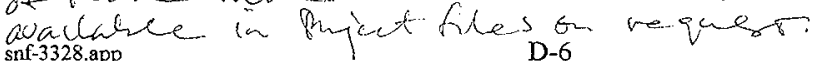


Document Reviewed: SNF-3328, Rev. 0, Canister Storage Building Design Basis Accident Analysis Documentation

Scope of Review: Chapter 6.0, "Thermal Runaway Reactions Inside the Multi-Canister Overpack"

Yes Ne N/A

[ ] [ ] X] Previous reviews complete and cover analysis, up to scope of this review, with no gaps.

[x] [ ] [ ] Problem completely defined.

W] [ ] [ ]

$\mathbb{Q}[][]$

$X[][]$

䜣[ [ ]

$\mathbb{X}[][]$

$\mathbb{E}[][]$

$\otimes[][]$

Accident scenarios developed in a clear and logical manner.

Necessary assumptions explicitly stated and supported.

Computer codes and data files documented.

Data used in calculations explicitly stated in document.

Data checked for consistency with original source information as applicable.

Mathematical derivations checked including dimensional consistency of results.

Models appropriate and used within range of validity or use outside range of established validity justified.

D [] [] Hand calculations checked for errors. Spreadsheet results should be treated exactly the same as hand calculations.

[x] [ ] [ ]

X] [] []

Software input correct and consistent with document reviewed.

W [ ] [ ]

Software output consistent with input and with results reported in document reviewed.

A [ ] [ ]

$\mathbb{X}[][]$

$\mathbb{X}[\mathrm{C}[\mathrm{]}]$

[x] [] []

[] [] $[X]$

Limits/criteria/guidelines applied to analysis results are appropriate and referenced.

Limits/criteria/guidelines checked against references.

\section{A [] Document approved.}

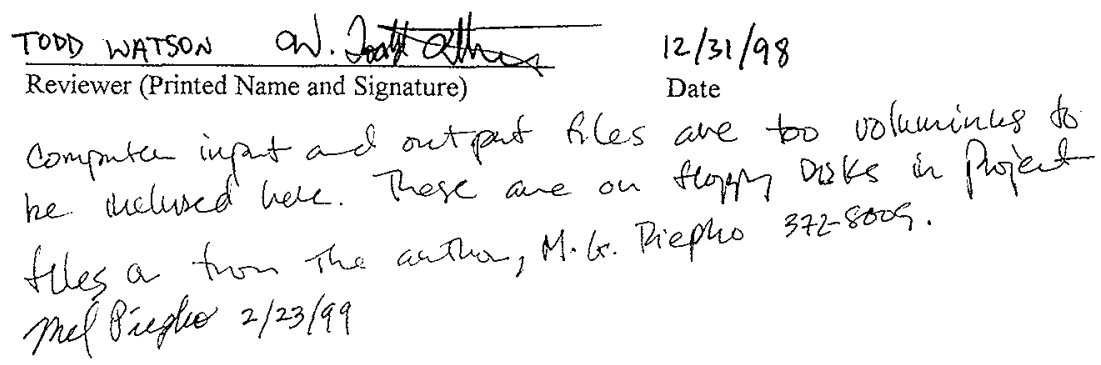




\section{CHECKLIST FOR PEER REVIEW}

Document Reviewed: SNF-3328, Rev. 0, Canister Storage Building Design Basis Accident Analysis Documentation, Chapter 6.0, "Thermal Runaway Reactions Inside the Multi-Canister Overpack"

Scope of Review: Entire chapter

Author:

M. G. Piepho

Yes NoNA

$凶[$ [ [ ] * Previous reviews complete and cover analysis, up to scope of this review, with no gaps.

$X]$ [ ] [ ] Problem completely defined.

$X][$ ] [ ] Accident scenarios developed in a clear and logical manner.

$\Delta]$ [ ] [ ] Necessary assumptions explicitly stated and supported.

Q [ ] [ ] Computer codes and data files documented.

$凶[$ [ ] [ ]

A [ ] [ [ ]

$\otimes[][]$

Data used in calculations explicitly stated in document.

Data checked for consistency with original source information as applicable.

Mathematical derivations checked including dimensional consistency of results.

W [ ] [ ] Models appropriate and used within range of validity or use outside range of established validity justified.

W [ ] [ ] Hand calculations checked for errors. Spreadsheet results should be treated exactly the same as hand calculations.

$\bowtie$ [ ] [ ] Software input correct and consistent with document reviewed.

Q] [ ] [ ] Software output consistent with input and with results reported in document reviewed.

め [ ] [ ] Limits/criteria/guidelines applied to analysis results are appropriate and referenced. Limits/criteria/guidelines checked against references.

$\mathbb{X}[][]$ Safety margins consistent with good engineering practices.

¿] [ ] [ ] Conclusions consistent with analytical results and applicable limits

$\Phi[][]$

[ ] [ ] $[X]$

[]$[x *$ Results and conclusions address all points required in the problem statement. Format consistent with appropriate NRC Regulatory Guide or other standards Review calculations, comments, and/or notes are attached.

X] I ] [ ] Document approved.

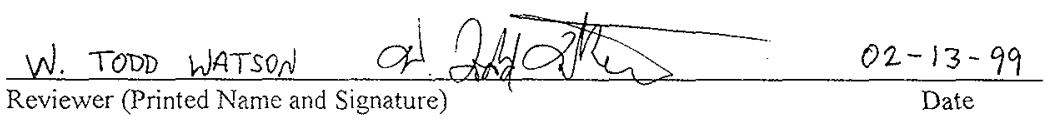

* Any calculations, comments, or notes generated as part of this review should be signed, dated and attached to this checklist. Such material should be labeled and recorded in such a manner as to be intelligible to a technically qualified third party. 
SNF-3328 REV 0

This page intentionally left blank. 


\section{CHECKLIST FOR PEER REVIEW}

Document Reviewed: $\quad$ SNF-3328, Rev. 0, Canister Storage Building Design Basis Accident Analysis Documentation, Chapter 7.0, "Violation of Design Temperature Criteria"

Scope of Review: Entire chapter

Author: W. T. Watson.

Yes No NA

[X] [ ] [ ] * Previous reviews complete and cover analysis, up to scope of this review, with no gaps.

[x] [ ] [ ] Problem completely defined.

[X] [ ] [ ] Accident scenarios developed in a clear and logical manner.

[X] [ ] [ ] Necessary assumptions explicitly stated and supported.

[ ] [ ] [X] Computer codes and data files documented.

[X] [ ] [ ] Data used in calculations explicitly stated in document.

[X] [ ] [ ] Data checked for consistency with original source information as applicable.

[ ] [ ] [X] Mathematical derivations checked including dimensional consistency of results.

[X] [ ] [ ] Models appropriate and used within range of validity or use outside range of established validity justified.

[X] [ ] [ ] Hand calculations checked for errors. Spreadsheet results should be treated exactly the same as hand calculations.

[ ] [ ] [X] Software input correct and consistent with document reviewed.

[ ] [ ] [X] Software output consistent with input and with results reported in document reviewed.

[X] [ ] [ ] Limits/criteria/guidelines applied to analysis results are appropriate and referenced. Limits/criteria/guidelines checked against references.

[X] [ ] [ ] Safety margins consistent with good engineering practices.

$[x][][]$

$[X][][]$

$[x][][]$

[ ] $[X]^{*}$ Review calculations, comments, and/or notes are attached.

\section{X [ ] [ ] Document approved.}

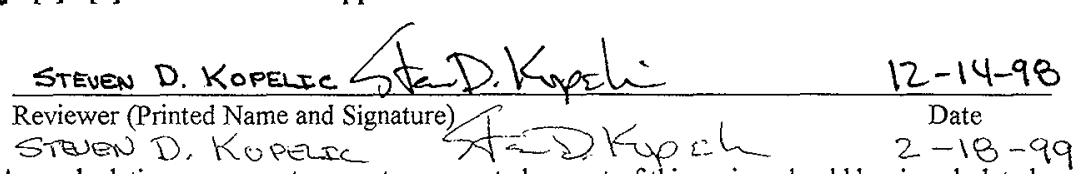

* Any calculations, comments, or notes generated as part of this review should be signed, dated and attached to this checklist. Such material should be labeled and recorded in such a manner as to be intelligible to a technically qualified third party. 


\section{CHECKLIST FOR PEER REVIEW}

Document Reviewed: $\quad$ SNF-3328, Rev. 0, Canister Storage Building Design Basis Accident Analysis Documentation, Chapter 8.0, "Recovery Actions Related to Gaseous Releases and Explosions from Overpack Storage Tubes"

Scope of Review: Entire chapter

Author:

W. T. Watson

\section{Yes No NA}

[A3 [ ] [ ] * Previous reviews complete and cover analysis, up to scope of this review, with no gaps.

[X] [ ] [ ] Problem completely defined.

$[x][][]$

[x] [ ] [ ]

[ ] [ ] $[x]$

[x] [ ] [ ]

$[x][][]$

[ ] [ ] $[x]$

$[x][][]$

[x] [ ] [ ]

[ ] [ ] $[x]$

[ ] [ ] $[x]$

[x] [ ] [ ]

$[x][][$ [ ]

$[x][][]$

$[x][][]$

$[x][][]$

Accident scenarios developed in a clear and logical manner.

Necessary assumptions explicitly stated and supported.

Computer codes and data files documented.

Data used in calculations explicitly stated in document.

Data checked for consistency with original source information as applicable.

Mathematical derivations checked including dimensional consistency of results.

[ ] $[X]^{*}$ Review calculations, comments, and/or notes are attached.

$M[1]$ I ] Document approved.

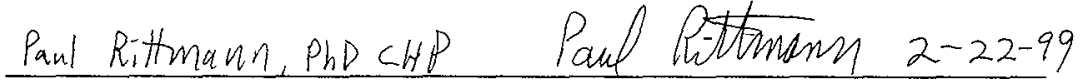

Reviewer (Printed Name and Signature)

Date

* Any calculations, comments, or notes generated as part of this review should be signed, dated and attached to this checklist. Such material should be labeled and recorded in such a manner as to be intelligible to a technically qualified third party. 
SNF-3328 REV 0

This page intentionally left blank. 
DISTRIBUTION SHEET

\begin{tabular}{|c|c|c|c|c|c|}
\hline \multirow{2}{*}{$\begin{array}{l}\text { To } \\
\text { Distribution }\end{array}$} & \multirow{2}{*}{\multicolumn{3}{|c|}{$\begin{array}{l}\text { From } \\
\text { Nuclear Safety }\end{array}$}} & \multicolumn{2}{|l|}{ Page 1 of 1} \\
\hline & & & & \multicolumn{2}{|l|}{ Date $2 / 25 / 99$} \\
\hline \multicolumn{4}{|l|}{ Project Title/Work Order } & \multicolumn{2}{|c|}{ EDT No. 624295} \\
\hline \multicolumn{4}{|c|}{$\begin{array}{l}\text { SNF-3328, Rev. } 0 \\
\text { Canister Storage Building Design Basis Accident Analysis Documentation }\end{array}$} & \multicolumn{2}{|l|}{ ECN No. N/A } \\
\hline Name & MSIN & $\begin{array}{c}\text { Text } \\
\text { With All } \\
\text { Attach. }\end{array}$ & Text Only & $\begin{array}{c}\text { Attach./ } \\
\text { Appendix } \\
\text { Only }\end{array}$ & $\begin{array}{c}\text { EDT/ECN } \\
\text { Only }\end{array}$ \\
\hline L. J. Garvin & $\mathrm{R} 3-26$ & $\mathrm{X}$ & & & \\
\hline S. B. Harrington (5) & R3-26 & $X$ & & & \\
\hline B. S. Lew & R3-26 & $\mathrm{X}$ & & & \\
\hline M.A. Medsker & R3-26 & $\mathbf{X}$ & & & \\
\hline R. P. Omberg & R3-26 & $\mathrm{X}$ & & & \\
\hline SNF Project Files & R3-11 & $\mathrm{X}$ & & & \\
\hline
\end{tabular}

